DARINE CHRISTINA MAIA VILLELA

\title{
ALTERAÇÕES GENÔMICAS E EPIGENÔMICAS NAS MANIFESTAÇÕES ANATOMOPATOLÓGICAS E COGNITIVAS DA DOENÇA DE ALZHEIMER
}

São Paulo 
DARINE CHRISTINA MAIA VILLELA

\section{ALTERAÇÕES GENÔMICAS E EPIGENÔMICAS NAS MANIFESTAÇÕES ANATOMOPATOLÓGICAS E COGNITIVAS DA DOENÇA DE ALZHEIMER}

Tese apresentada ao Departamento de Genética e Biologia Evolutiva do Instituto de Biociências da Universidade de São Paulo, para a obtenção do Título de Doutor em Ciências, na Área de Biologia/Genética.

\section{São Paulo}


DARINE CHRISTINA MAIA VILLELA

\section{ALTERAÇÕES GENÔMICAS E EPIGENÔMICAS NAS MANIFESTAÇÕES ANATOMOPATOLÓGICAS E COGNITIVAS DA DOENÇA DE ALZHEIMER}

Tese apresentada ao Departamento de Genética e Biologia Evolutiva do Instituto de Biociências da Universidade de São Paulo, para a obtenção do Título de Doutor em Ciências.

Área de concentração: Biologia/Genética. Orientadora: Profa. Dra. Carla Rosenberg.

\section{São Paulo}


Villela, Darine Christina Maia.

Alterações Genômicas e Epigenômicas nas Manifestações Anatomopatológicas e Cognitivas da Doença de Alzheimer / Darine Christina Maia Villela - São Paulo, 2014.

Orientador(a): Carla Rosenberg.

Tese (Doutorado) - Universidade de São Paulo. Instituto de Biociências, Departamento de Genética e Biologia evolutiva. Área de concentração: Genética Humana. Linha de Pesquisa: Citogenética Humana.

Versão do título para o inglês: Genomic and Epigenomic Alterations in the Anatomopathological and Cognitive Manifestations of Alzheimer's disease.

Descritores: 1. Doença de Alzheimer. 2. Variação no número de cópias de segmentos de DNA (CNV). 3. Metilação do DNA. 4. Hibridação comparativa de genoma em arrays (array-CGH) I. Rosenberg, Carla II. Universidade de São Paulo. Instituto de Biociências. Programa de Pós-Graduação em Genética Humana. III. Título.

Comissão Julgadora:

$\operatorname{Prof(a).\operatorname {Dr}(a).:}$

Prof(a). Dr(a):

Prof(a). Dr(a).:

$\operatorname{Prof(a).\operatorname {Dr}(a).:}$

Orientador(a): Prof ${ }^{\mathrm{a}}$. Dra. Carla Rosenberg 
Este trabalho foi realizado com os auxílios financeiros da FAPESP (Fundação de Amparo à Pesquisa do Estado de São Paulo) concedidos à orientadora Profa. Dra. Carla Rosenberg (Processo No 2009/00898-1), ao CEPID (Processo No 2013/08028-1) e à aluna Darine Christina Maia Villela (Processo No 2010/15503-0). 
Aos meus pais, Nelson e Marcia, e ao meu noivo, Rodrigo, por todo amor, companheirismo e compreensão, mas, sobretudo, pelo apoio e incentivo na realização desse trabalho. 


\section{AGRADECIMENTOS}

À minha orientadora, Dra Carla Rosenberg, por ter me acolhido em seu laboratório, por todos os ensinamentos, pela amizade e confiança depositada em mim

À Dra Ana Krepischi pelos ensinamentos, contribuição e por suas valiosas idéias

Aos colaboradores do Banco de Encéfalos Humanos do Grupo de Estudos em Envelhecimento Cerebral (BEHGEEC) da Faculdade de Medicina da USP, os Drs. Lea Grinberg, Claudia Suemoto, Carlos Augusto Pasqualucci, Renata Leite e todos os outros participantes, pela ajuda na seleção das amostras usadas nesse estudo, pela disponibilidade e cooperação

Ao Dr. David Schlesinger pelas sugestões na fase de elaboração desse projeto

Ao Dr. Peter Pearson pela discussão de resultados e por todos os ensinamentos

À Silvia e à Ligia pelo apoio técnico, amizade e inestimável ajuda

Aos amigos do laboratório Erika, Jacaré, Amanda, Tatiane, Giselle, Alex, Francine pelo convívio e amizade

Ao meu irmão Caio e minha avó Carolina por todo amor e carinho

À Fundação de Amparo à Pesquisa do Estado de São Paulo (FAPESP) pelo apoio financeiro

Enfim, a todos que contribuíram diretamente ou indiretamente para a concretização desse trabalho 


\section{RESUMO}

Villela, D. Alterações Genômicas e Epigenômicas nas Manifestações Anatomopatológicas e Cognitivas da Doença de Alzheimer. [Tese]. São Paulo: Instituto de Biociências da Universidade de São Paulo; 2014.

A doença de Alzheimer (DA) é a causa mais comum de demência na população, sendo responsável por cerca de 50 a $60 \%$ dos casos. Embora o diagnóstico clínico da doença na maioria das vezes seja acurado, a confirmação da DA só é feita post mortem através principalmente da caracterização dos dois tipos principais de lesões neurais: depósitos extracelulares de placas de $\beta$ amiloide e emaranhados de proteína tau hiperfosforilada. Até o momento, o envolvimento de apenas quatro genes foi confirmado na etiologia da DA, três deles (APP, PSEN1 e PSEN2) associados à forma familial de herança mendeliana, que corresponde a um tipo raro e grave. No entanto, apesar de inúmeros trabalhos de associação genômica, (Genome wide association studies- GWAS) sugerirem uma possível participação de vários outros genes na suscetibilidade à manifestação da forma multifatorial da DA, o gene $A P O E$, ainda é o único consistente e reproduzivelmente associado à doença. As descobertas derivadas dos GWAS investigando o papel de SNPs coletivamente explicam somente uma pequena porcentagem da variação herdada que contribui para o risco de desenvolver a DA. Atualmente, há novas abordagens para investigar a base genética do restante da variabilidade fenotípica herdada e que pode influenciar a suscetibilidade ao desenvolvimento de doenças complexas. O papel da variação do número de cópias de segmentos de DNA (Copy Number Variation - CNV) na genética de doenças complexas foi demonstrado por diversos estudos nos últimos anos e evidencia que desequilíbrios genômicos também podem contribuir significantemente para a resistência ou susceptibilidade a várias patologias. Outro aspecto que vem assumindo crescente importância é a análise de modificações epigenéticas que podem constituir um mecanismo molecular básico e contribuir diretamente para a patogênese da DA. Logo, este trabalho teve como objetivo principal investigar dois aspectos relacionados à DA: (1) a identificação de CNVs que podem estar contribuindo para o desenvolvimento da forma multifatorial da DA, usando a técnica de $\operatorname{array-CGH}$, e (2) a análise de alterações do padrão global de metilação do DNA no córtex frontal de indivíduos com a forma multifatorial da DA, usando um microarranjo que interroga o status de metilação de 450.000 sítios CpGs. Em 
nossa investigação sobre desequilíbrios genômicos na DA, identificamos 6 CNVs raras com conteúdo gênico relevante para o fenótipo investigado. Dois indivíduos distintos do grupo DA apresentam microduplicações em genes que codificam diferentes subunidades do mesmo tipo de canal de $\mathrm{Ca}^{2+}$ dependente de voltagem, o tipo L. Além disso, dos outros genes selecionados como especialmente interessantes, 4 estão envolvidos em diferentes processos inflamatórios e 1 é responsável por codificar a enzima nicotinamida fosforibosiltransferase, participante importante da via de biossíntese da molécula nicotinamida adenina dinucleotídeo (NAD). A implicação de um possível envolvimento de mediadores da sinalização celular do $\mathrm{Ca}^{2+}$ e da via de biossíntese da NAD na etiologia da DA também foi reforçada pelos nossos resultados sobre o padrão de metilação do DNA na DA. Dois genes importantes para a homeostasia intracelular do $\mathrm{Ca}^{2+}$ e via de biossíntese da NAD apresentaram sítios CpGs diferenciamente metilados nos sujeitos com DA.

Palavras-chave: doença de Alzheimer, variação no número de cópias de segmentos de DNA (CNV), desequilíbrios genômicos, array-CGH, metilação do DNA. 


\begin{abstract}
Villela, D. Genomic and Epigenomic Alterations in the Anatomopathological and Cognitive Manifestations of Alzheimer's disease. [PhD Thesis]. São Paulo: Institute of Biosciences, University of São Paulo, 2014.
\end{abstract}

Alzheimer's disease (AD) is the most common form of dementia in the population, corresponding to $50-60 \%$ of all cases. Although clinical diagnosis seems to be accurate, the definitive diagnosis of the disease can only be made by a post mortem neuropathological exam that certifies the presence of the two hallmarks of $\mathrm{AD}$ : the accumulation of extracellular senile plaques containing $\beta$-amyloid $(\mathrm{A} \beta$ ) and the intracellular neurofibrillary tangles containing hyperphosphorylated tau protein. Four genes are known to be involved in the etiology of $\mathrm{AD}$, three of them (APP, PSEN1 and PSEN2) are associated to the familial form of the disease, which show autosomal dominant inheritance and correspond to the more severe and rare type of AD. Despite many genome wide association studies (GWAS), APOE still remains the only unequivocal genetic risk factor associated to the multifactorial form of AD. The discoveries from GWAS using SNPs collectively explain only a small percentage of heritable variation that may contribute in AD risk. Currently, new approaches have been used to investigate the genetic basis of the phenotypical variability inheritance that can influence the susceptibility of complex diseases. The important role of DNA copy number variation $(\mathrm{CNV})$ has been demonstrated by several studies over the last years and shows that genomic imbalances may also significantly contribute to resistance or susceptibility to various complex diseases. Additionally, there is now increasing interest in exploring how epigenetic modifications, in particular DNA methylation, could influence complex diseases etiology. Thus, the major aim of this work were to investigate two aspects related to the multifactorial form of $\mathrm{AD}$ : (1) identification of rare $\mathrm{CNVs}$, using array-CGH, that could contribute to the development of the disease, and (2) analysis of the DNA methylation pattern in frontal cortex of individuals with AD. In our study, we identified 6 rare CNVs with relevant gene content to the investigated phenotype. Two distinct subjects with AD from our casuistic presented microduplications in genes that encode different subunits of the same type of $\mathrm{Ca}^{2+}$ voltage channel, the L-type. Furthermore, among the other selected genes, four are involved in different inflammatory process and one encodes the nicotinamide phosphoribosyltransferase 
enzyme, important mediator of nicotinamide adenine dinucleotide (NAD) biosynthesis. The implication of a possible involvement of $\mathrm{Ca}^{2+}$ intracellular signaling mediators and NAD biosynthesis pathway in the etiology of AD was also reinforced by our analysis of DNA methylation pattern. Interestingly, two important genes, one to intracellular $\mathrm{Ca}^{2+}$ homeostasis and the other to NAD biosynthesis pathway presented CpGs sites differently methylated in the AD subjects.

Keywords: Alzheimer's disease, copy number variation (CNV), genomic imbalance, arrayCGH, DNA methylation. 


\section{LISTA DE FIGURAS}

Figura 1. Alois Alzheimer e Auguste Deter.

Figura 2. Lesões típicas da doença de Alzheimer

Figura 3. Vias de processamento do peptídeo $\beta$ amiloide $(A \beta)$ através da clivagem da proteína precursora amiloide (APP).

Figura 4. Hipótese da cascata amiloide .33

Figura 5. Representação do mecanismo mais comum que dá origem aos desequilíbrios genômicos recorrentes 38

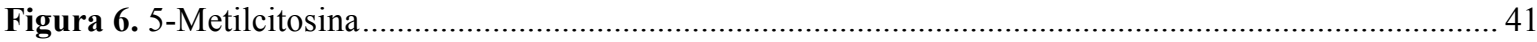

Figura 7. Anatomia molecular dos sítios CpGs na cromatina e seu papel na expressão gênica.....................44

Figura 8. Distribuição da frequência das amostras controle e doença de Alzheimer (DA), usadas no estudo sobre a investigação de variações no número de cópias de segmentos de DNA (CNVs), de acordo com seus respectivos valores correspondentes aos estágios de Braak. .58

Figura 9. Fluxograma com todas as etapas realizadas na análise do padrão de metilação do DNA em nosso estudo

Figura 10. Microduplicação de $\sim 665 \mathrm{~Kb}$ em 3p21.1 presente no indivíduo 09-06787 .................................72

Figura 11. Microduplicação de 300 Kb em 3p21.31 presente no indivíduo 05-06917 ............................ 73

Figura 12. Microduplicação de $462 \mathrm{~Kb}$ em 10p15.1-p14 presente no indivíduo 07-08805 ......................... 74

Figura 13. Microduplicação de $\sim 90 \mathrm{~Kb}$ em 22q13.2 presente no indivíduo 08-02984 ............................... 75

Figura 14. Microduplicação de $\sim 665$ Kb em 3p21.1 presente no indivíduo 09-06787 ................................ 76

Figura 15. Microdeleção de $\sim 129$ Kb em 12q22 presente no indivíduo 09-02544 .....................................77

Figura 16. Microdeleção de 145 Kb em 7q22.2 presente no indivíduo 06-11388 …............................... 78

Figura 17. Consequências das variações raras no número de cópias de segmentos de DNA (CNVs) presentes no grupo doença de Alzheimer (DA).

Figura 18. Análise de redes de interação molecular realizada através do programa computacional Ingenuity Pathway Analysis

Figura 19. Associação dos genes considerados diferencialmente metilados com diferentes funções biológicas

Figura 20. Média por indivíduo do número total de variações no número de cópias de segmentos de DNA (CNVs) detectadas nas análises de array-CGH em amostras de sangue versus tecido cerebral ...... 86

Figura 21. Média por indivíduo do número total de variações no número de cópias de segmentos de DNA (CNVs) detectadas nas análises de array-CGH em amostras pareadas de indivíduos controle 86

Figura 22. Distribuição da frequência dos níveis de metilação nos grupos controle (A) e doença de Alzheimer (B) nos 471.994 sítios CpG presente na plataforma 450K da Illumina (Infinium Human Methylation 450K BeadChips)

Figura 23. Distribuição dos valores de Delta Beta e $\mathrm{CpG}$ considerados diferencialmente metilados .88 
Figura 24. Visão geral do padrão de metilação do DNA na doença de Alzheimer utilizando a plataforma $450 \mathrm{~K}$ da Illumina

Figura 25. Cluster hierárquico dos 54 loci considerados diferencialmente metilados. 93

Figura 26. Análise de redes de interação molecular realizada através do programa computacional Ingenuity Pathway Analysis 95

Figura 27. Associação dos genes considerados diferencialmente metilados com diferentes funções biológicas 96

Figura 28. Valores de Beta dos sítios CpGs diferencialmente metilados associados aos genes MAPT, INPP5A, NMNAT3, ADAMTS19, CUX1 e FAM66A.... 97

Figura 29. Distribuição dos níveis de metilação ao longo de todos os sítios CpG do gene ADAMTS19 99

Figura 30. Distribuição dos níveis de metilação ao longo de todos os sítios $\mathrm{CpG}$ do gene $F A M 66 A \ldots \ldots \ldots \ldots . . . .100$

Figura 31. Distribuição dos níveis de metilação ao longo de alguns sítios CpG do gene $C U X 1$................... 101

Figura 32. Distribuição dos níveis de metilação ao longo de alguns sítios $\mathrm{CpG}$ do gene $M A P T$. 102

Figura 33. Distribuição dos níveis de metilação ao longo de todos os sítios CpG do gene INPP5A 103

Figura 34. Distribuição dos níveis de metilação ao longo de todos os sítios CpG do gene NMNAT3 ..... 104

Figura S1. Distribuição dos níveis de metilação ao longo de todos os sítios $\mathrm{CpG}$ do gene $C A C N A 1 C$...... 152

Figura S2. Distribuição dos níveis de metilação ao longo de todos os sítios $\mathrm{CpG}$ do gene $C A C N A 2 D 2 \ldots \ldots . . .153$

Figura S3. Distribuição dos níveis de metilação ao longo de todos os sítios CpG do gene CACNA2D3........ 154

Figura S4. Distribuição dos níveis de metilação ao longo de todos os sítios $\mathrm{CpG}$ do gene $C R A A D$ 155

Figura S5. Distribuição dos níveis de metilação ao longo de todos os sítios $\mathrm{CpG}$ do gene $P R K C Q$. 156

Figura S6. Distribuição dos níveis de metilação ao longo de todos os sítios CpG do gene NFAMI 157

Figura S7. Distribuição dos níveis de metilação ao longo de todos os sítios $\mathrm{CpG}$ do gene $I L 17 R B$ 158

Figura S8. Distribuição dos níveis de metilação ao longo de todos os sítios $\mathrm{CpG}$ do gene $N A M P T$ 159

Figura S9. Distribuição dos níveis de metilação ao longo de todos os sítios $\mathrm{CpG}$ do gene $A P O E$..... 160

Figura S10. Distribuição dos níveis de metilação ao longo de todos os sítios $\mathrm{CpG}$ do gene $B I N 1$ 161

Figura S11. Distribuição dos níveis de metilação ao longo de todos os sítios $\mathrm{CpG}$ do gene $C L U$ 162

Figura S12. Distribuição dos níveis de metilação ao longo de todos os sítios $\mathrm{CpG}$ do gene $A B C A 7$..... 163

Figura S13. Distribuição dos níveis de metilação ao longo de todos os sítios CpG do gene CR1 .................. 164

Figura S14. Distribuição dos níveis de metilação ao longo de todos os sítios CpG do gene PICALM ........... 165

Figura S15. Distribuição dos níveis de metilação ao longo de todos os sítios CpG do gene MS4A6A ........... 166

Figura S16. Distribuição dos níveis de metilação ao longo de todos os sítios CpG do gene CD33 ................167

Figura S17. Distribuição dos níveis de metilação ao longo de todos os sítios CpG do gene $C D 2 A P$.......... 168 


\section{LISTA DE TABELAS}

Tabela 1. Descrição de todos os casos do grupo Doença de Alzheimer para o estudo sobre a investigação de variações no número de cópias de segmentos de DNA (CNVs)..... 56

Tabela 2. Descrição de todos os casos do grupo controle para o estudo sobre a investigação de variações no número de cópias de segmentos de DNA (CNVs).

Tabela 3. Descrição de todos os casos do grupo Doença de Alzheimer para o estudo global do padrão de metilação do DNA.

Tabela 4. Descrição de todos os casos do grupo controle para o estudo global do padrão de metilação do DNA

Tabela 5. Resumo da distribuição de todas as CNVs encontradas nos grupos controle e Doença de Alzheimer

Tabela 6. Tamanho e densidade gênica das CNVs raras encontradas nos grupos controle e Doença de Alzheimer. 68

Tabela 7. Descrição de todas as CNVs raras encontradas no grupo controle ............................................. 70

Tabela 8. Descrição de todas as CNVs raras encontradas no grupo Doença de Alzheimer ...... 71

Tabela 9. Consequências das variações raras no número de cópias de segmentos de DNA (CNVs) dos genes considerados relevantes para a doença de Alzheimer

Tabela 10. Tamanho e densidade gênica das CNVs encontradas nos indivíduos da amostra pareada de controle 86

Tabela 11. Sítios $\mathrm{CpG}$ considerados diferencialmente metilados entre os grupos controle e Doença de Alzheimer após critérios de exclusão para análise dos dados de metilação 91

Tabela S1. Todos os 250 sítios $\mathrm{CpG}$ considerados diferencialmente metilados entre os grupos controle e Doença de Alzheimer sem nenhum critério de exclusão 143 


\section{LISTA DE QUADROS}

Quadro 1. Domínios avaliados na entrevista clínica e as respectivas escalas utilizadas..... 


\title{
LISTA DE ABREVIATURAS
}

\author{
ABIPEME Associação Brasileira de Institutos de Pesquisa de Mercado \\ APP proteína precursora amiloide \\ $\mathrm{A} \beta$ \\ peptídeo $\beta$ amiloide \\ BEHGEEC Banco de Encéfalos Humanos do Grupo de Estudos em Envelhecimento Cerebral da \\ Faculdade de Medicina da USP \\ CCDV-L canal de $\mathrm{Ca}^{2+}$ dependente de voltagem do tipo $\mathrm{L}$ \\ CCL comprometimento cognitivo leve \\ CDR escala de demência clínica \\ $\mathrm{CNV}$ \\ variações no número de cópias de segmentos de DNA \\ DA doença de Alzheimer \\ DECIPHER Database of Chromosomal Imbalances and Phenotype in humans using Ensembl \\ Resources \\ DGV \\ Database of Genomic Variants \\ DMRs \\ regiões diferencialmente metiladas \\ DNMTs \\ enzimas DNA metiltransferases \\ FoSTeS \\ Fork Stalling and Template Switching \\ GWAS \\ estudos de associação genômica \\ hiPSC \\ IP3 \\ células-tronco humanas pluripotentes induzidas \\ IsCG \\ canais 1,4,5-trifosfato inositol \\ LCRs \\ ilhas $\mathrm{CpG}$ \\ LINEs \\ regiões com baixo número de cópias \\ elementos longos dispersos transponíveis \\ LMRs \\ low-methylated regions, regiões com pouca metilação \\ MAPT \\ proteína Tau associada a microtúbulos \\ MBDs \\ proteínas de ligação a metil-CpG \\ MMBIR replicação induzida por quebra mediada por microhomologia \\ MVP \\ posições de metilação variável \\ NAD \\ nicotinamida adenina dinucleotídeo \\ NAHR \\ recombinação homóloga não alélica \\ NAMPT \\ enzima nicotinamida fosforibosiltransferase \\ NDR \\ regiões livres de nucleossomos \\ $\mathrm{NF}-\kappa \mathrm{B}$ \\ fator nuclear kappa B \\ NHEJ \\ junção de extremidades não homólogas \\ NMNAT3 \\ enzima nicotinamida mononucleotídeo adeniltransferase 3 \\ NPI \\ Neuropsychiatric Inventory
}


odd ratio, estimativa de risco relativo

PIP2

fosfatidilinositol 4.5-bifosfato

PSEN 1 e 2

Presenilina 1 e 2

$\mathrm{RC}$

reserva cognitiva ou reserva cerebral

RNAPII

RNA polimerase II

SCID

Structured Clinical Interview for DSM Disorders

SINEs

elementos curtos dispersos transponíveis

SIT sítios de início de transcrição

SNPs

polimorfismos de nucleotídeo único

SVO

Serviço de Verificação de Óbitos

TAR trombocitopenia-aplasia radial

TNF- $\alpha$ fator de necrose tumoral $\alpha$

VEP Variant Effect Predictor 


\section{SUMÁRIO}

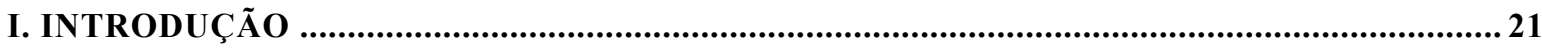

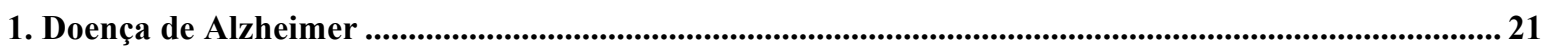

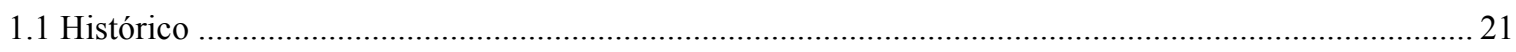

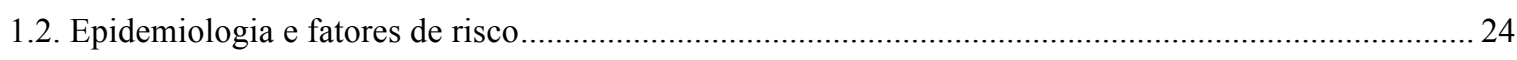

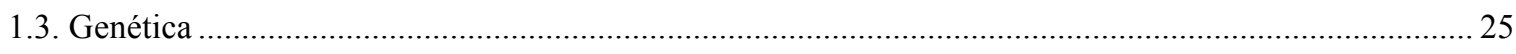

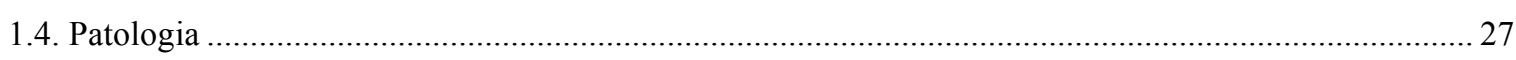

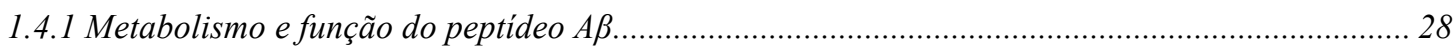

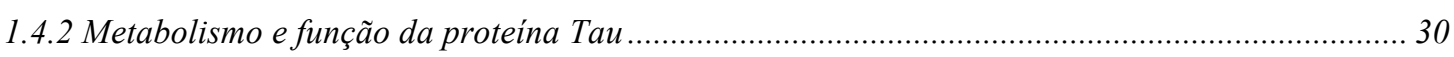

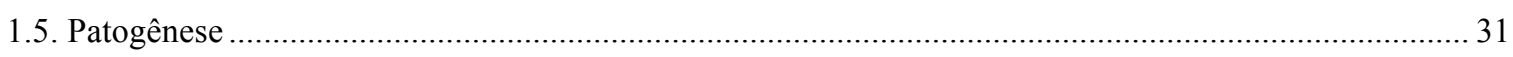

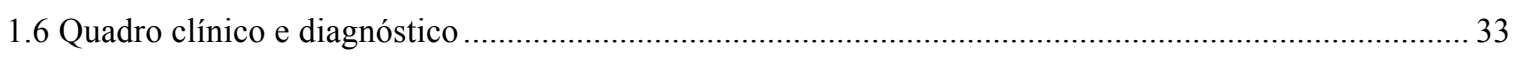

2. Desequilíbrios genômicos - variações no número de cópias de segmentos de DNA (Copy number

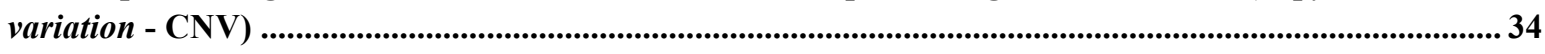

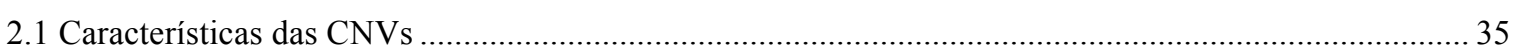

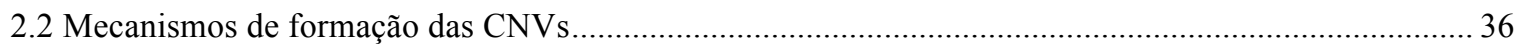

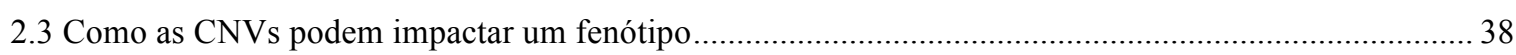

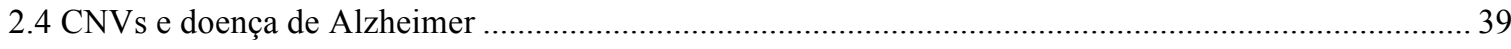

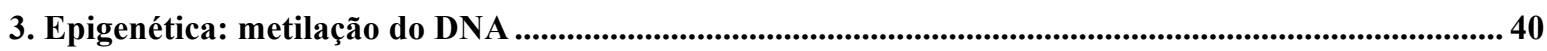

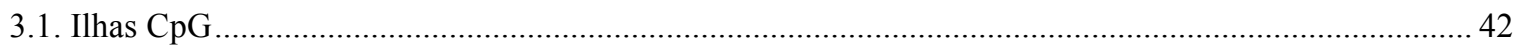

3.1.1. Funções da metilação do DNA das IsCG nos sítios de início de transcrição, no corpo de genes e em

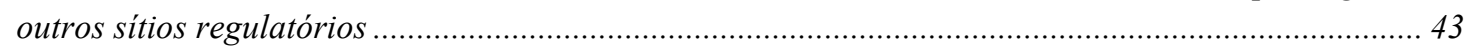

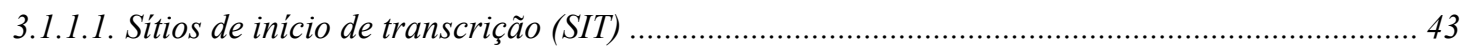

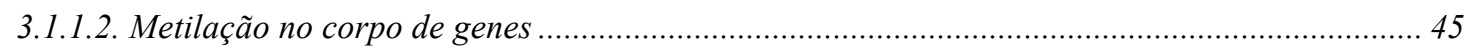

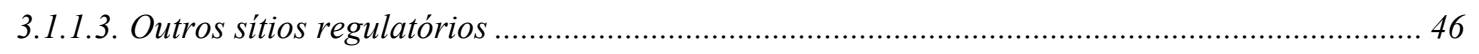

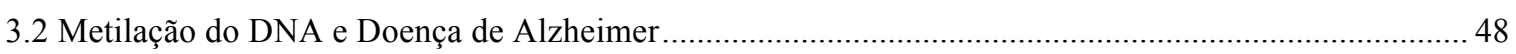

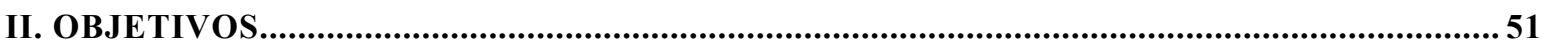

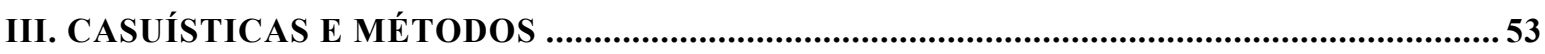

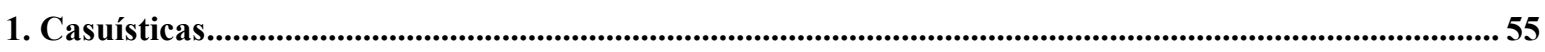

1.1. Parte I. Estudo sobre a investigação de variações no número de cópias de segmentos de DNA (CNVS) na

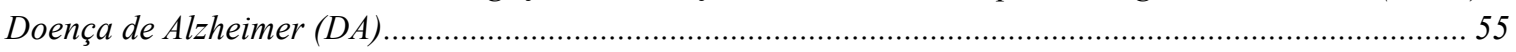

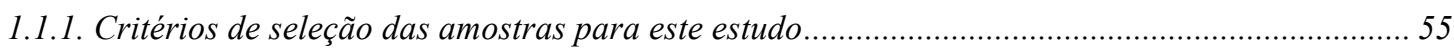

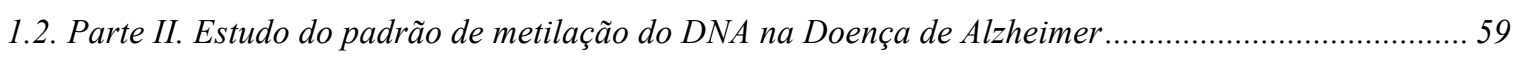

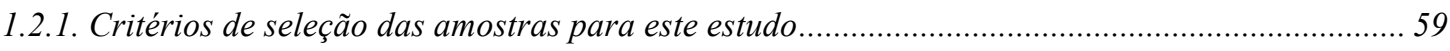

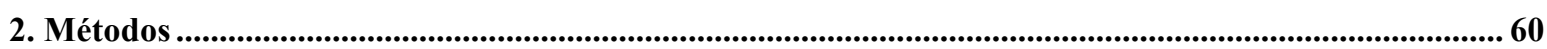

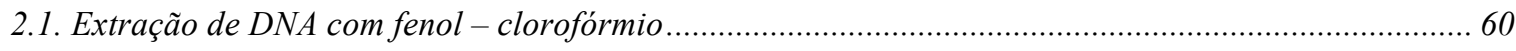

2.2. Investigação de desequilibrios genômicos submicroscópicos por array-CGH ……...................................... 60

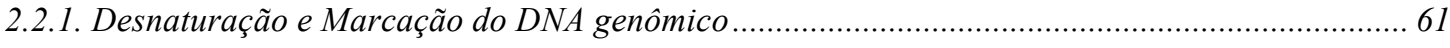

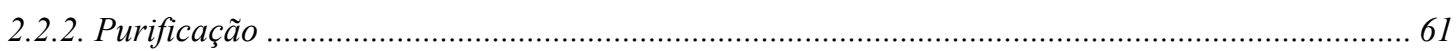

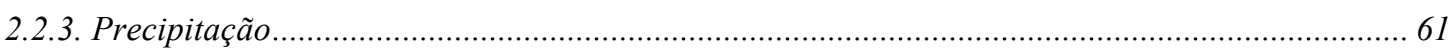




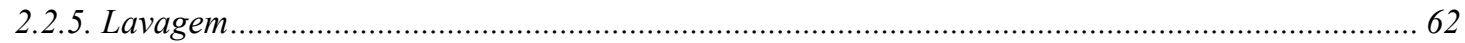

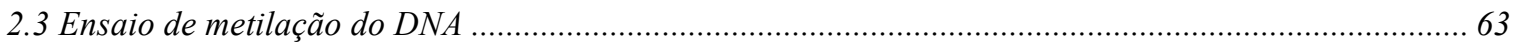

2.3.1 Escaneamento e processamento dos dados .................................................................................. 63

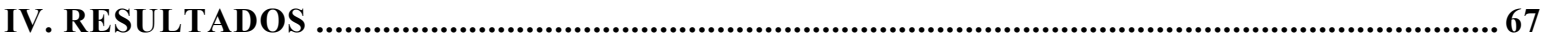

1. Parte I. Estudo sobre a investigação de variações no número de cópias de segmentos de DNA (CNV) na

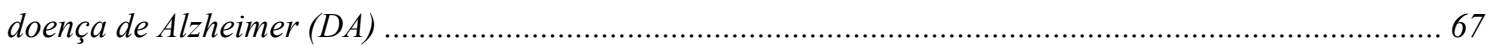

2. Parte II. Estudo do padrão de metilação do DNA na Doença de Alzheimer (DA).................................. 87

V. DISCUSSÃO

106

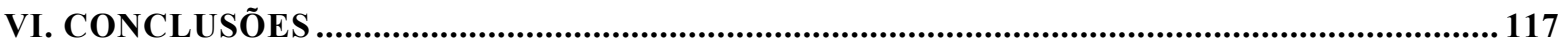

VII. REFERÊNCIAS BIBLIOGRÁFICAS ......................................................................... 120

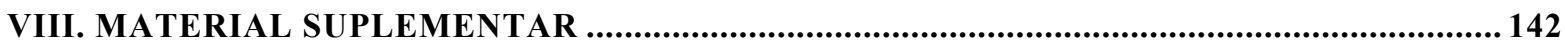

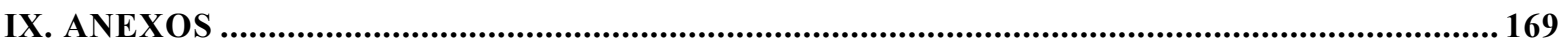

Anexo I - Resultados submetidos para publicação na revista BMC Research Notes) ......................1 170

Anexo II - Resultados aceitos para publicação na revista Journal of Genetics) ............................. 183

Anexo III - Manuscrito publicado na revista Genetics and Molecular Biology) ............................ 199 
I. INTRODUÇÃO 


\section{Doença de Alzheimer}

\subsection{Histórico}

Muito embora a deterioração mental progressiva na velhice tenha sido descrita e reconhecida ao longo de toda história, foi somente em 1906 que um médico alemão, Dr. Alois Alzheimer (1864-1915) (Figura 1A), correlacionou uma série de achados neuropatológicos com observações clínicas e influenciou de maneira importante o curso da psiquiatria moderna. Em 4 de novembro do referido ano, Dr. Alzheimer apresentou pela primeira vez o caso de sua paciente, Auguste Deter (1850-1906), na $37^{\mathrm{a}}$ Conferência Anual dos Psiquiatras Alemães, em Tübingen - Alemanha (Graeber 2003).

Auguste Deter foi internada em novembro de 1901 pelo seu marido, Karl Deter, em uma Instituição Mental em Frankfurt - Alemanha. Hospitalizada aos 51 anos de idade, Auguste apresentava graves problemas de memória e déficits de linguagem assim como vários distúrbios psicológicos como desorientação e alucinações. Tais sintomas correspondiam ao que era denominado de demência ${ }^{1}$ naquela época, no entanto, ela era muito jovem para apresentá-los. Em sua primeira entrevista clínica, Dr. Alzheimer fez perguntas muito similares às que são feitas hoje em dia a um paciente com a doença que leva seu nome (Maurer et al., 1997; O'Brien 1996). Os arquivos de Auguste Deter ainda são mantidos preservados, em um trecho escrito por Dr. Alzheimer e datado de 26 de novembro de 1901, lê-se:

\footnotetext{
${ }^{1}$ Durante o século XVIII, o termo demência era usado para se referir aos estados de incompetência psicossocial independentemente de antecedentes de reversibilidade, idade ou estado patológico. Essa visão ampla foi gradualmente sendo modificada, culminando no fim do século XIX com o chamado "paradigma cognitivo", em que a visão de demência passou a ser considyerada um transtorno irreversível (principalmente em idosos) das funções intelectuais, especialmente a memória. Este paradigma está em vigor até hoje, apesar de ter sido parcialmente modificado durante os anos 80 , quando foi aceito que características não cognitivas, como alucinações, delírios e déficits comportamentais também faziam parte da doença.
} 


\begin{abstract}
"Ela senta-se na cama com uma expressão desamparada. Qual é o seu nome? Auguste. Sobrenome? Auguste. Qual o nome do seu marido? Auguste, eu acho. Seu marido? Ah, meu marido. Ela me olha como se não entendesse a pergunta. Você é casada? Com Auguste. Senhora Deter? Sim, sim, Auguste Deter. A quanto tempo você está aqui? Ela parece tentar se lembrar. Três semanas. O que é isso? Eu lhe mostro um lápis. Uma caneta. Bolsa, chave, diário e cigarro são respondidos corretamente. No almoço ela comeu couve-flor e porco. Questionada o que estava comendo, ela respondeu espinafre. Quando estava mastigando carne e the perguntaram o que estava comendo, ela respondeu batatas e raiz forte. Quando objetos lhe são mostrados, ela não se lembra deles em um curto espaço de tempo. Nos intervalos ela sempre fala sobre gêmeos. Quando convidada a escrever, ela segura o livro de tal forma que se tem a impressão de que possui uma perda no campo visual direito. Solicitada a escrever Auguste Deter, ela tenta escrever Senhora e esquece o resto. É necessário repetir cada palavra. Desordem da escrita amnésica. À noite, seu discurso espontâneo é cheio de descarrilhamento de paráfrases e perseverações." (Maurer et al., 1997).
\end{abstract}

Por ser muito nova, Auguste Deter foi diagnosticada com demência pré-senil. Ela permaneceu internada até sua morte e durante sua estada sua condição piorou significativamente; experimentou declínio cognitivo, alucinações e eventualmente a perda de quase toda sua habilidade cognitiva (Figura 1B). Quando morreu em 8 de abril de 1906, Dr. Alzheimer estava trabalhando na Clínica Psiquiátrica Royal em Munique com Emil Kraepelin, um dos psiquiatras alemães mais importantes da época (Berrios 1990; Maurer et al., 1997). Após o conhecimento da morte de sua paciente, pediu permissão à família para realizar uma autópsia no seu cérebro. Observou uma atrofia cerebral, especialmente no córtex, e a análise microscópica revelou depósitos anormais dentro e entre as células nervosas, aos quais ele se referiu como placas miliares e feixes densos de fibrila, respectivamente (na terminologia moderna, placas de beta amiloide e emaranhados neurofibrilares da proteína Tau). Outros cientistas já haviam relatado tais alterações, mas essa era a primeira vez que eram observados em alguém tão jovem (Berrios 2005; Ramirez-Bermudez 2012).

Dr. Alzheimer descreveu o caso de Auguste Deter na $37^{\text {a }}$ Conferência Anual dos Psiquiatras Alemães como a “doença peculiar do córtex cerebral”. No ano seguinte, publicou sua apresentação como um manuscrito e somente em 1911 escreveu um artigo mais detalhado interpretando suas observações, em que também descreve o caso de Johann F. e uma série de outros pacientes com o mesmo quadro clínico (Berrios 1990). O caso de Johann F. é especialmente interessante e também teve notoriedade, pois apesar de um quadro clínico semelhante ao de Auguste Deter, com manifestação precoce de demência, aos 54 anos de idade, enquanto a autópsia de Auguste Deter mostrou dois tipos de depósitos, a análise microscópica do cérebro de Johann F. revelou apenas a presença de placas extracelulares (Klunemann et al., 2002). Esta observação foi confirmada no final da década de 90, quando 
uma equipe de pesquisa descobriu seções intactas de tecido cerebral de Johann F. nos arquivos da Universidade de Munique, do Instituto de Neuropatologia (Berrios 1990).

(A)

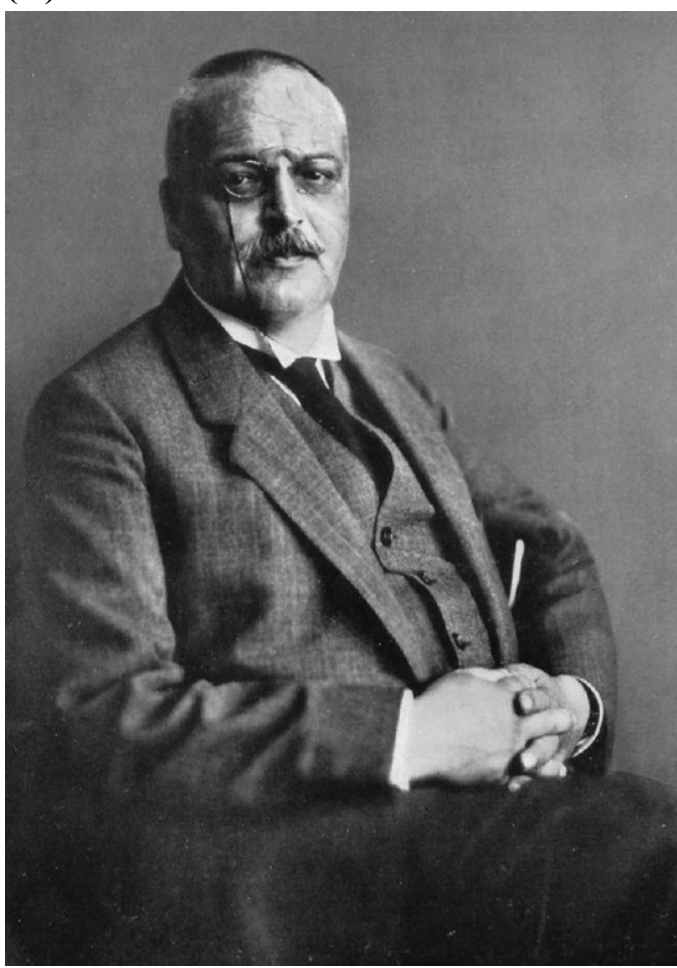

(B)

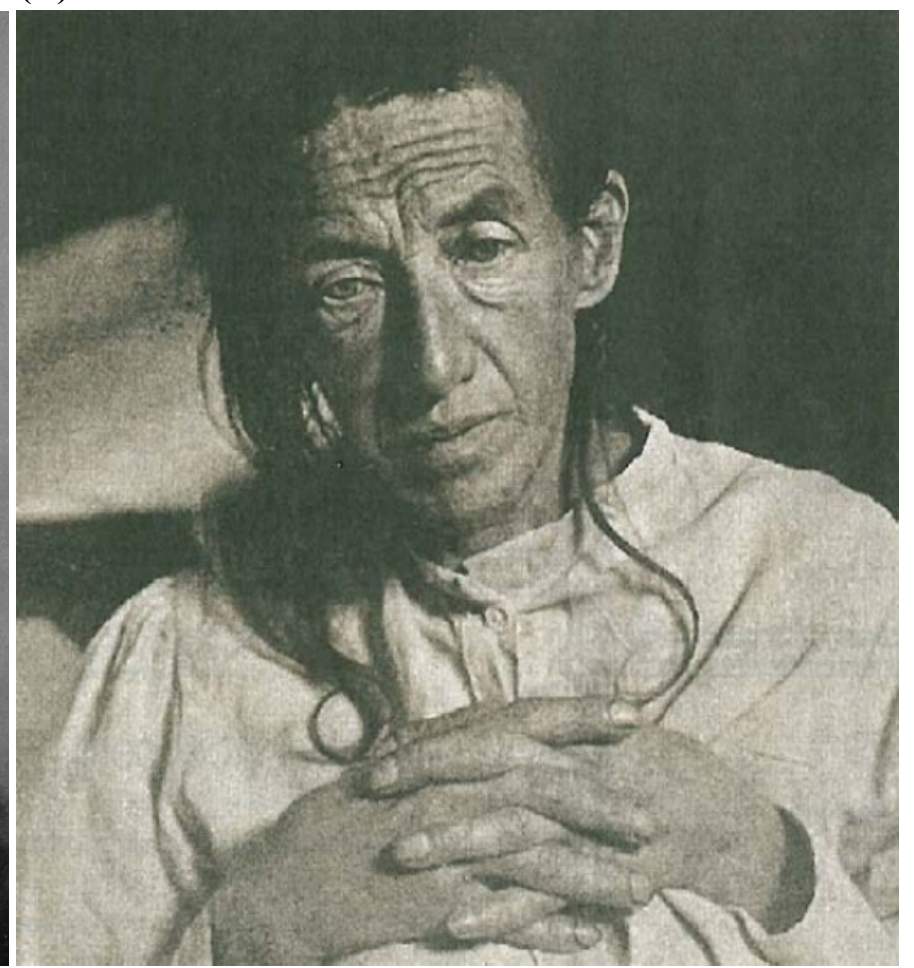

Figura 1. Alois Alzheimer e Auguste Deter. (A) Dr. Alois Alzheimer (1864-1915), neuropatologista e psiquiatra alemão que ficou famoso ao descrever o primeiro caso de demência pré-senil. (B) Auguste Deter (1850-1906), primeira paciente diagnosticada por Dr. Alzheimer com demência pré-senil, em uma Instituição Mental em Frankfurt - Alemanha, aos 55 anos de idade, pouco antes de sua morte.

FONTE: Maurer et al. 1997.

A sugestão de que o nome de Alzheimer fosse dado a esta síndrome veio de seu chefe, Emil Kraepelin. Considerado por muitos como o fundador da psiquiatria científica, Kraepelin incluiu a descrição do caso de Auguste Deter na 8 a edição de seu livro Psychiatrie, publicado em 1910 (Weber 1997). Alguns cientistas na época se mostraram surpresos por quão rápido Kraepelin nomeou esta condição como uma doença distinta, alegavam que o caso de Auguste representava apenas uma forma atípica, mais severa, de demência senil. Ainda, uma interpretação mais conservadora sobre os trabalhos de Alzheimer sugere que sua intenção era simplesmente mostrar que a demência senil também podia ocorrer em pessoas mais jovens (Berrios 2005; Ramirez-Bermudez 2012).

De qualquer maneira, mais e mais casos como os de Auguste Deter e Johann F. logo foram sendo relatados e passaram a ser relacionados com o nome de Alzheimer. No entanto, quase que imediatamente após a descrição dos dois tipos principais de lesão, os cientistas começaram a observar casos menos típicos, revelando que a doença realmente tratava-se de um 
fenômeno complexo (Ramirez-Bermudez 2012). Já na década de 30, foi publicada uma série de casos da doença de Alzheimer (DA) com vários indivíduos afetados em cada geração, consistente a um padrão de herança autossômico dominante. Assim como Auguste Deter, a idade de manifestação da doença era inferior aos 65 anos idade, o que levaram os médicos a confirmar a distinção entre demência pré-senil e demência senil (McMenemey et al., 1939). Na década de 80 , no entanto, se tornou evidente que a demência senil, que possui idade de manifestação mais tardia e que apresenta as mesmas lesões típicas da demência pré-senil, são essencialmente idênticas, e foi então chamada por Terry e Davies de demência do tipo Alzheimer (Terry e Davies 1980).

Apesar de existirem algumas controvérsias sobre se Dr. Alzheimer teria ou não descoberto uma nova doença, é inegável sua contribuição para a neuropatologia moderna. Seu maior sucesso foi o interesse pelas correlações entre clínica e patologia, algo muito pouco comum para a época. Esta postura certamente orientou todo o pensamento médico ocidental, influenciando novas descobertas e patrocinando descrições de novas formas de demência com diferentes substratos patológicos.

\subsection{Epidemiologia e fatores de risco}

Dentre os diversos tipos de demência existentes, a DA é a causa mais comum no mundo inteiro, sendo responsável por cerca de 50 a $60 \%$ de todos os casos. A prevalência de pessoas diagnosticadas com DA, com idade abaixo ou entre 60 e 65 anos, é de aproximadamente $1 \%$. Porém, este número apresenta um aumento quase exponencial com o passar dos anos e, em razão disso, indivíduos com 85 anos ou mais apresentam uma prevalência de 24 a 33\% (Mayeux 2003). Caso não exista uma estratégia efetiva de prevenção ou tratamento para a DA e, sobretudo, com o aumento da expectativa de vida na população mundial, estima-se que no ano de 2020, o número de pessoas diagnosticadas com DA será de 42 milhões, o dobro de casos se comparado a 2005 (Ferri et al., 2005). Dados representativos de países em desenvolvimento, como o Brasil, são escassos. No entanto, estudos sobre a prevalência global da DA indicam que quase $60 \%$ dos pacientes moram nestes países e que este número tende a aumentar para $71 \%$ até 2020 (Ferri et al., 2005).

Apesar da idade ser o fator de risco mais óbvio para a DA, diversos estudos epidemiológicos tentaram associar outros possíveis fatores de risco à doença. Alguns trabalhos apontam que uma atividade intelectual permanente parece protelar o início e o aparecimento de demências como a DA, pois permite a formação contínua de novas sinapses, promovendo o que se conhece por reserva cognitiva ou reserva cerebral (RC) (Mortimer et al., 2003). Do ponto de 
vista neurobiológico, a RC é entendida como a densidade sináptica neocortical, ou seja, o acúmulo de conexões interneuronais na substância cinzenta do córtex; agindo através de mecanismos protetores e compensatórios esta confere ao cérebro a habilidade de tolerar melhor mudanças relacionadas a idade (Stern 2012). Várias pesquisas indicam que indivíduos com alto nível de escolaridade, melhor habilidade de leitura ou com um coeficiente de inteligência acima da média apresentam um índice de prevalência e incidência menor da DA (Mortimer et al., 2003). Além disso, outros fatores de risco como doença vascular, hipercolesterolemia, hipertensão, aterosclerose, doença coronária, tabagismo, obesidade e diabetes também já foram associados à doença (Gatz et al., 2006; Mayeux e Stern 2012). Porém, ainda é necessário esclarecer se estas condições podem conduzir processos patogênicos da DA ou se elas induzem a uma patologia cerebrovascular, a qual aumenta a fase da doença clinicamente silenciosa, logo, expandindo o início de manifestação de demência. Apesar dos trabalhos citados sugerirem que fatores ambientais possam aumentar o risco de desenvolvimento da DA, um grande estudo populacional com gêmeos mono e dizigóticos demonstrou que o fator genético é mais preponderante, mostrando que a doença apresenta uma herdabilidade significativa, de quase $80 \%$ (Gatz et al., 2006).

\subsection{Genética}

Do ponto de vista genético, a DA é uma doença heterogênea que apresenta duas formas de manifestação. O tipo mais raro e grave é a forma familial e segue o padrão de herança mendeliano; frequentemente está associado com uma manifestação mais precoce da doença, com início antes dos 65 anos (Tanzi e Bertram 2005). Em 1991, um estudo com pacientes que apresentavam a forma familial da DA, revelou uma mutação no gene que codifica a proteína precursora amiloide (APP) (Goate et al., 1991). No entanto, pesquisadores, ao investigar outras famílias que também possuíam o tipo mais grave da doença, concluíram que mutações nos genes presenilina 1 e $2(P S E N \quad 1$ e 2) são responsáveis pela maioria dos casos familiais (Sherrington et al., 1995). Porém, estas mutações explicam cerca de 1\% de todos os casos da DA (Harvey et al., 2003), enquanto que a grande maioria corresponde à forma multifatorial que tem determinantes genéticos mais complexos e representa o tipo mais comum da doença na população.

Apesar de apresentar uma herdabilidade significativa, o tipo mais comum da DA não apresenta um padrão de herança monogênico e está relacionado com uma manifestação mais tardia da doença (Bergem et al., 1997; Gatz et al., 1997). Até o momento, o único gene comprovadamente associado com suscetibilidade à forma multifatorial da DA é o gene $A P O E$, 
o qual codifica a apolipoproteína $\mathrm{E}$ - uma proteína de transporte de colesterol no cérebro para o reuso em lipídios de membrana e reparo neuronal (Poirier et al., 1993). Em 1993, Strittmatter e colaboradores examinaram as três formas alélicas da APOE: $\varepsilon 2$, $\varepsilon 3$ e $\varepsilon 4$, em pacientes com DA e indivíduos saudáveis. Os resultados mostraram um excesso significativo da variante $\varepsilon 4$ entre pacientes e revelaram que pessoas com descendência européia heterozigotas $\varepsilon 3 \varepsilon 4$ possuem duas ou três vezes mais risco de desenvolver DA se comparadas às homozigotas $\varepsilon 3 \varepsilon 3$ (Corder et al., 1993; Strittmatter et al., 1993). Além disso, indivíduos homozigotos $\varepsilon 4 \varepsilon 4$ apresentam duas vezes mais risco do que heterozigotos $\varepsilon 3 \varepsilon 4$, enquanto que heterozigotos $\varepsilon 2$ possuem um risco reduzido de desenvolver a doença (Farrer et al., 1997; Meyer et al., 1998; Poirier et al., 1993), evidenciando que a variante $\varepsilon 4$ se comporta como um fator de predisposição para a DA. Estudos apontam ainda que a presença do alelo $\varepsilon 4$ pode influenciar a idade de manifestação da doença, diminuindo em aproximadamente 10 anos o início dos primeiros sintomas (Blennow et al., 2006).

Depois da associação do gene $A P O E$ com a forma não mendeliana da $\mathrm{DA}$, vários trabalhos tentaram relacionar outros possíveis genes candidatos à doença, sendo que a grande maioria desses estudos de mapeamento gênico focava exclusivamente na contribuição de SNPs (polimorfismos de nucleotídeo único - single nucleotide polymorphisms - SNPs) na DA. Um dos principais motivos para isso ter ocorrido se dá ao fato de que dentre as várias descobertas importantes provenientes do Projeto Genoma Humano em 2001 está o reconhecimento da abundância de SNPs possivelmente como a maior fonte de variação genética, o que levou à especulação na época de que a variabilidade fenotípica na população humana era devida principalmente à mudanças de bases únicas (Ionita-Laza et al., 2009).

Uma estratégia muito utilizada nos últimos anos para investigar fatores genéticos que influenciam o desenvolvimento de doenças é a de estudos de associação genômica (genomewide association studies - GWAS), os quais consistem em investigar variações genéticas no genoma inteiro, através da genotipagem de milhares de SNPs, e fazer associações entre fenótipos clínicos e regiões contendo variantes de suscetibilidade. No entanto, a despeito de todo esforço e recursos financeiros já gastos, os resultados destes estudos de maneira geral têm sido abaixo do esperado em termos de elucidação dos fatores genéticos envolvidos em patologias complexas como a DA (Moore e Williams 2009). Ao longo dos últimos anos fícou evidente que variantes comuns com grande efeito (como a presença do alelo $\varepsilon 4$ no gene $A P O E$ ) para doenças complexas são raras, e que a maioria dos SNPs conferem um risco moderado à doença (Van Es e Van den Berg 2009). 
Embora exista um número grande de estudos de associação com a DA, a grande maioria está abaixo do poder estatístico para detectar variantes genéticas com efeito moderado devido ao tamanho limitado no número de amostras. Vale ressaltar ainda que a estimativa de risco relativo (odd ratio-OR) acima de 1,5, considerada significativa para os GWAS, não foi alcançada para nenhum desses estudos. Considerando, por exemplo, os dois últimos trabalhos de GWAS para a DA (Harold et al., 2009; Lambert et al., 2009) que apresentam a maior coorte já estudada, foram caracterizadas novas variantes em SNPs presentes nos genes CRI, $C L U$ e PICALM, que não tinham sido até então associadas com a DA, com OR de 1,17, 0,74 e 0,57, respectivamente. Contudo, mesmo com um OR abaixo do que é considerado significativo para os GWAS, os achados desses dois últimos manuscritos tiveram grande impacto na comunidade científica e vêm sendo replicados por alguns estudos independentes (Jun et al., 2010; Kamboh et al., 2012; Olgiati et al., 2011). Hoje em dia variantes em CRl, $C L U$ e PICALM são consideradas, portanto, importates fatores de risco genético para DA. Apesar da sua inegável contribuição, as descobertas derivadas dos GWAS coletivamente explicam, no entanto, ainda somente uma pequena porcentagem da variação herdada que contribui para o risco de desenvolver a DA. Atualmente, uma das novas perspectivas para os estudos genéticos é investigar o que contribui para o restante da variabilidade fenotípica herdada e que pode influenciar a suscetibilidade ao desenvolvimento de doenças complexas como a DA.

\subsection{Patologia}

Em uma análise macroscópica, embora o cérebro post mortem de um indivíduo com DA não apresente nenhuma alteração grande capaz de determinar o diagnóstico da doença, ainda assim, é possível observar uma modesta atrofia cortical (principalmente envolvendo o córtex frontotemporal associativo), dilatação simétrica dos ventrículos laterais e atrofia significativa do hipocampo, com dilatação seletiva do corno temporal adjacente ao ventrículo lateral (Perl 2010). Já microscopicamente, a DA é caracterizada por dois tipos principais de lesões: (1) emaranhados neurofibrilares resultantes da acumulação intraneuronal da proteína Tau hiperfosforilada e (2) placas neuríticas (ou senis) que contém depósitos extracelulares do peptídeo $\beta$ amiloide (A $\beta$ ) (Avramopoulos 2009) (Figura 2). Essas lesões típicas são encontradas preferencialmente no lobo medial temporal e nas áreas corticais do cérebro, juntamente com a degeneração de neurônios e sinapses. Outras características patológicas também associadas à DA são: disfunção neurovascular, anormalidades do ciclo celular, processo inflamatório, estresse oxidativo e disfunção mitocondrial (Blennow et al., 2006). 


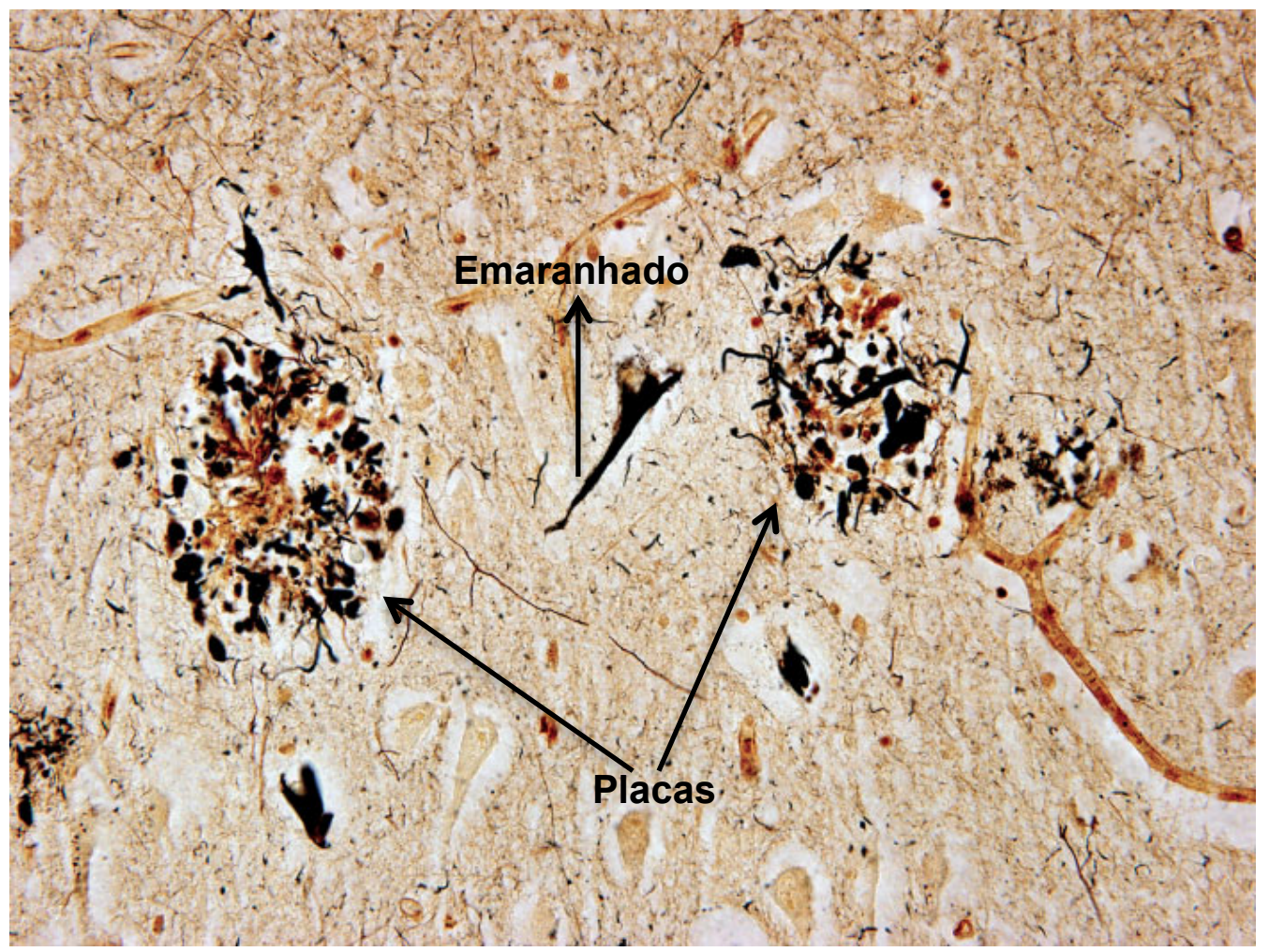

Figura 2. Lesões típicas da doença de Alzheimer. Fotomicrografia do córtex temporal de um indivíduo com doença de Alzheimer mostrando a presença de duas placas extracelulares de $\beta$ amiloide e um emaranhado intracelular da proteína tau entre elas.

FONTE: Adaptada de Perl 2010

\subsubsection{Metabolismo e função do peptídeo Aß}

A descoberta de uma correlação entre o número de placas senis e a gravidade de manifestação da demência colocou um foco grande no envolvimento das placas na patogênese da DA (Blessed et al., 1968). Em meados dos anos 80, os pesquisadores conseguiram identificar a sequência de aminoácidos do peptídeo $A \beta$, como a proteína mais abundante que as compunha, o que contribuiu para que mais tarde houvesse a clonagem do gene $A P P$, responsável por codificar a proteína precursora amiloide (Blennow et al., 2006).

Inicialmente, acreditava-se que o peptídeo $A \beta$ encontrado nas placas senis era uma proteína anormal. Contudo, após a constatação de que este é produzido constitutivamente durante o metabolismo celular normal é que se propôs duas vias para o seu processamento através da clivagem da proteína APP (Figura 3) (Querfurth e LaFerla 2010). APP, uma das proteínas mais abundantes do sistema nervoso central, pertence a uma grande família de proteínas de membrana do tipo I e possui um longo domínio extracelular $\mathrm{N}$-terminal, que inclui o domínio $\beta$-amiloide, e uma pequena região citoplasmática $\mathrm{C}$-terminal que fica parcialmente ancorada na membrana plasmática (Querfurth e LaFerla 2010). A via 
predominante de processamento da APP é a chamada não amiloidogênica, realizada por um complexo enzimático denominado $\alpha$-secretase. Nesta via, a clivagem da APP ocorre dentro do domínio $\beta$-amiloide, na região N-terminal, liberando o fragmento $\alpha$-sAPP no meio extracelular. $\mathrm{O}$ fragmento $\mathrm{C}$-terminal remanescente, $\alpha-\mathrm{CTF}$, é clivado pelo complexo $\gamma$ secretase que libera um peptídeo pequeno, composto por 31-37 aminoácidos, chamado de p3 (Avramopoulos 2009; Querfurth e LaFerla 2010; Zhang 2012; Zhang e Saunders 2007). Alternativamente, na via amiloidogênica, a APP é clivada pelo complexo enzimático $\beta$ secretase em uma região anterior ao domínio $\beta$ amiloide, formando o fragmento $\beta$-sAPP, sendo este também liberado no meio extracelular. Ancorado à membrana, permanece o fragmento $\beta$-CTF, que após clivado pelo complexo $\gamma$-secretase, libera o peptídeo A $\beta$. Este pode apresentar tamanhos variados e os mais abundantes no cérebro são os formados por 40 a 42 aminoácidos, A $\beta 40$ e A $\beta 42$ (Avramopoulos 2009; Querfurth e LaFerla 2010; Zhang 2012; Zhang e Saunders 2007). Sob condições normais, 90\% do peptídeo A $\beta$ secretado é a isoforma $A \beta 40$, sendo esta mais solúvel e facilmente eliminada do cérebro. Já $A \beta 42$, que representa menos de $10 \%$ das isoformas secretadas, é altamente insolúvel e propensa a agregação (Zhang et al., 2002). Inicialmente, os peptídeos A $\beta 42$ são liberados como monômeros, e na região extracelular podem se agregar em dímeros, trímeros, oligômeros, protofilamento, filamentos, depósitos originando, primeiramente, as placas difusas e, posteriormente, as placas senis de $\beta$ amiloide (Roberts et al., 1994).

As formas intermediárias de $\mathrm{A} \beta$ e os oligômeros solúveis são considerados os mais neurotóxicos, porém os mecanismos responsáveis pela neurotoxicidade de $A \beta$ ainda não são inteiramente compreendidos. Evidências sugerem que o aumento da atividade neuronal eleve a secreção de $A \beta$, em um processo intimamente ligado à secreção de vesículas de neurotransmissores (Querfurth e LaFerla 2010). Fisiologicamente, imagina-se que a secreção de $\mathrm{A} \beta$ sirva como um sistema tamponante, evitando hiperexcitabilidade neuronal (Kamenetz et al., 2003). Na DA, no entanto, o excesso de A $\beta$ pode prejudicar a excitabilidade celular e a comunicação na região de sinapses, pois $\mathrm{A} \beta$ parece estar envolvida na desregulação da homeostase intracelular do cálcio e potássio, assim como na indução de estresse oxidativo e no favorecimento de vias apoptóticas (Kamenetz et al., 2003). 


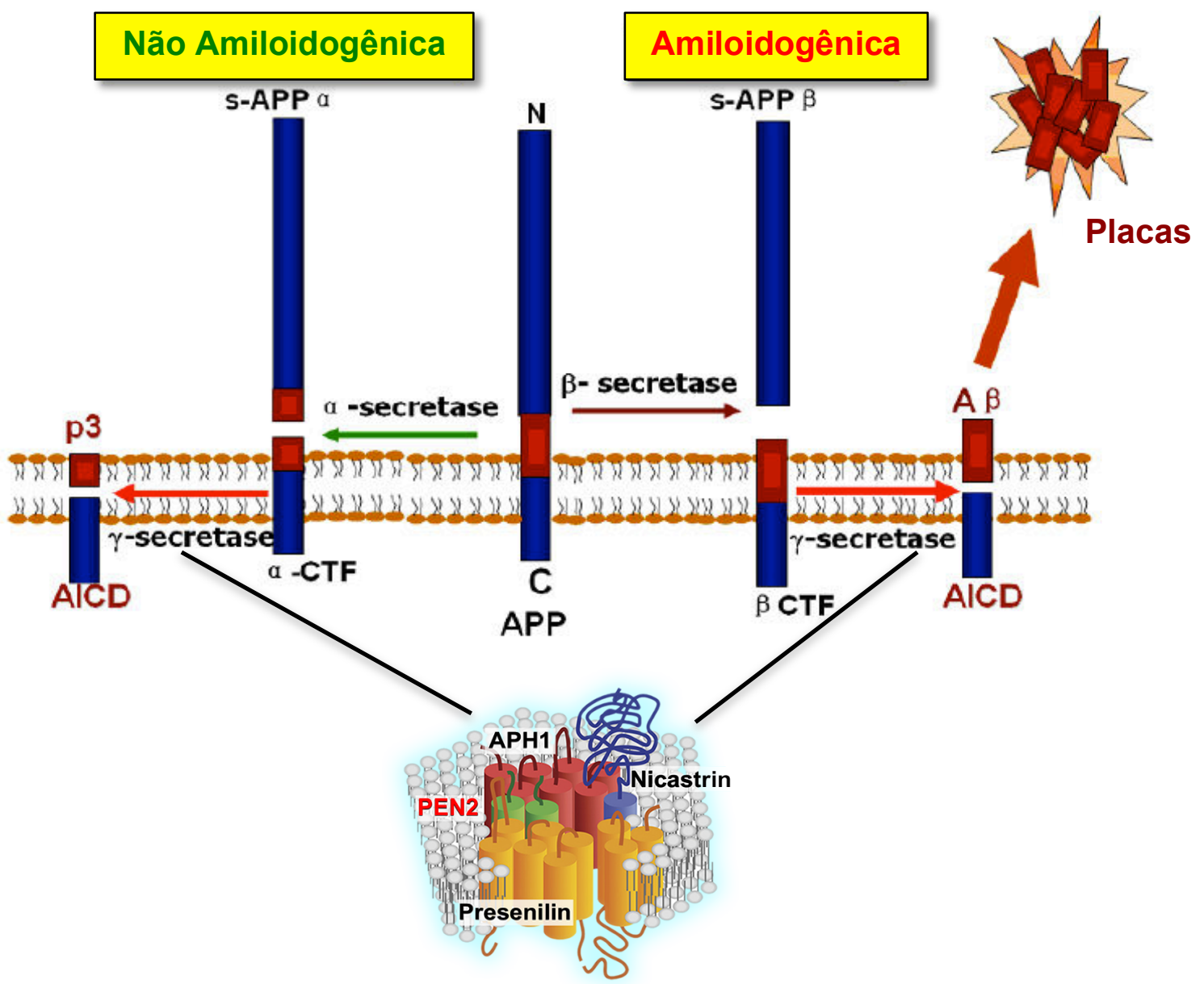

Figura 3. Vias de processamento do peptídeo $\beta$ amiloide $(A \beta)$ através da clivagem da proteína precursora amiloide (APP). APP é uma proteína transmembrana com um domínio extracelular N-terminal grande e um domínio $\beta$-amiloide, parcialmente ancorado na membrana plasmática, que inclui 28 resíduos de aminoácidos do lado extracelular e os primeiros 12-14 resíduos localizam-se no domínio transmembrana. APP pode ser processada por duas via principais. Na via $\alpha$-secretase (não amiloidogênica), a APP é clivada pela $\alpha$-secretase dentro do domínio $\beta$-amiloide, liberando o fragmento $\alpha$-sAPP no meio extracelular. $\mathrm{O}$ fragmento $\mathrm{C}$-terminal remanescente, $\alpha-\mathrm{CTF}$, é clivado pelo complexo $\gamma$-secretase que libera um peptídeo pequeno, composto por 31-37 aminoácidos, chamado de p3. $\gamma$ secretase é um complexo intramembranoso formado por 4 componentes: presenilina, nicastrina, PEN-2 e APH-1, sendo que a presenilina é a subunidade catalítica desse complexo. Já na via $\beta$-secretase (amiloidogênica) a APP é clivada pela $\beta$ secretase antes do domínio $\beta$ amiloide, liberando no meio extracelular o fragmento $\beta$-sAPP e o domínio C-terminal remanescente, $\beta-\mathrm{CTF}$, é clivado pelo complexo $\gamma$ secretase, liberando o peptídeo A $\beta$ de 40 ou 42 aminoácidos. Em ambas as vias, o domínio intracelular excedente da APP (AICD) é metabolizado no citoplasma.

FONTE: Adaptada de Zhang, 2007.

\subsubsection{Metabolismo e função da proteína Tau}

Os emaranhados neurofibrilares são inclusões filamentosas presentes majoritariamente nos neurônios piramidais e são encontrados não somente na DA como também em outras doenças neurodegenerativas, todas elas sendo classificadas como tauopatias (Querfurth e LaFerla 2010). O componente principal destas inclusões é a proteína Tau associada a microtúbulos (MAPT, microtubule-associated protein Tau), cuja função é ligar-se aos 
polímeros $\alpha$ e $\beta$ globulina dos microtúbulos conferindo-lhes estabilidade. A interação de Tau com a tubulina é um processo dinâmico no qual a Tau promove sua própria polimerização e inibe a rápida despolimerização da tubulina (Drechsel et al., 1992). Sua função é regulada pelo estado de fosforilação e desfosforilação compreendidos em 79 sítios de sua proteína, gerando mudanças conformacionais que influenciam na sua interação com as proteínas constituintes do microtúbulo. Esse processo é mediado por múltiplas quinases, como a enzima glicogênio sintase quinase 3 beta, a GSK3B, e a quinase dependente de ciclina 5, a CDK5; além de ser contrabalanceado pelas fosfatases PP-1 e PP-2 (Iqbal et al., 2005). Porém, devido a disfunções em proteínas que modulam sua fosforilação, a Tau, na DA, passa a apresentar uma taxa de fosforilação maior, tornando-se hiperfosforilada. Esse estado alterado de fosforilação, promove o sequestro de isoformas normais, gerando a despolimerização e a desestabilização dos microtúbulos. Esses eventos levam ao comprometimento do transporte axonal, afetando a função neuronal e sináptica e contribuem para a formação de fibras e emaranhados insolúveis na região do corpo celular e posteriormente nas regiões axonais e dendríticas (Iqbal et al., 2005).

\subsection{Patogênese}

Embora ainda não seja possível determinar a causa exata da DA, a hipótese da cascata amiloide continua sendo o esquema mais bem definido e estudado para explicar seu surgimento (Figura 4). Esta prediz que o evento inicial da doença é um desequilíbrio entre a produção e a depuração do peptídeo $\mathrm{A} \beta$ no cérebro, resultando por fim em degeneração neuronal e demência (Hardy e Higgins 1992; Reitz 2012). Evidências a favor dessa hipótese incluem o fato de que mutações responsáveis pela forma familial da DA estão presentes em genes que servem como substrato ou que regulam o processamento do peptídeo $\mathrm{A} \beta(A P P \mathrm{e}$ PSEN1 e 2). Ademais, indivíduos com síndrome de Down, que possuem uma cópia extra do gene $A P P$, desenvolvem placas de $\beta$ amiloide precocemente durante a vida (Hardy e Higgins 1992; Reitz 2012). Portanto, no caso da forma familial, a doença surge em decorrência de uma expressão elevada dos genes mutados, o que gera um aumento na produção do peptídeo $A \beta$ 42. Já na forma multifatorial, supõe-se que ocorra uma falha na eliminação do peptídeo $\mathrm{A} \beta$, causando um aumento gradual dos níveis desse peptídeo no cérebro (Hardy e Higgins 1992; Reitz 2012).

Ainda, a acumulação de $A \beta$ e a formação de oligômeros parecem estar associadas diretamente a uma característica proeminente na DA - a morte neuronal. Acredita-se que tais oligômeros, ainda intracelulares, sejam capazes de estimular a clivagem da proteína APP pela 
via amiloidogênica e quando liberados da célula, estimulem as células vizinhas a fazer o mesmo, amplificando o nível de A $\beta$ nestas células também (Pimplikar 2009). Os oligômeros solúveis de $A \beta$ parecem estar diretamente envolvidos com a inibição da potencialização de longo prazo do hipocampo através da interação com receptores de membrana de neurônios, podendo corromper a plasticidade sináptica (Walsh e Selkoe 2007). Além disso, como consequência à uma deposição gradual de oligômeros de $\mathrm{A} \beta 42$ em placas difusas, ocorre uma série de eventos celulares como respostas inflamatórias causadas pela ativação de microglias e astrócitos, estresse oxidativo e alteração da homeostasia iônica neuronal (Pimplikar 2009). Vale ressaltar que de acordo com a hipótese da cascata amiloide, a formação dos emaranhados neurofibrilares da proteína Tau seria resultado de uma série de alterações prévias, mas que também poderia contribuir para a manifestação dos sintomas de demência (Reitz 2012).

Apesar de ter grande aceitação no meio científico, alguns pesquisadores tentam falsear esta hipótese, uma vez que alguns estudos demonstram que a deposição de placas não prediz a severidade da doença (Duyckaerts et al., 2009; Zhu et al., 2007), além também de já terem sido encontrados depósitos de placas em idosos não-demenciados (Selkoe 1991). No entanto, é incontestável que a hipótese da cascata amiloide conduziu o pensamento sobre os estudos da DA nos últimos anos e teve uma grande influência principalmente na indústria farmacêutica no desenvolvimento de fármacos para conter a progressão da doença (Karran et al., 2011). 


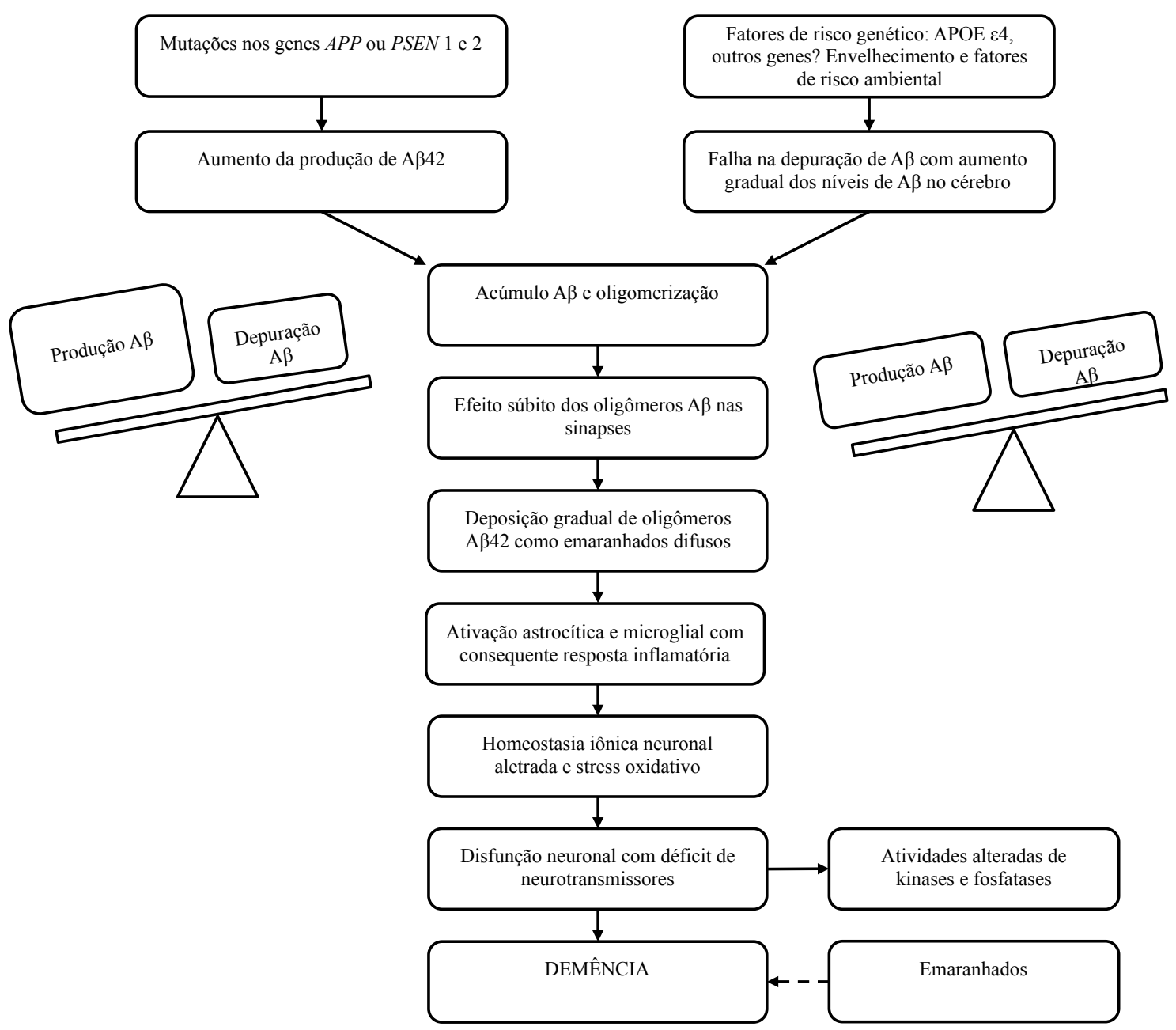

Figura 4. Hipótese da cascata amiloide. De acordo com essa hipótese, o evento central na patogênese da doença de Alzheimer (DA) seria um desequilíbrio entre a produção e a depuração do peptídeo $\beta$ amiloide (A $\beta$ ) no cérebro. No caso da forma familial da DA, a doença seria resultado de um aumento na produção de $\mathrm{A} \beta$, enquanto que na forma multifatorial ocorreria uma falha na depuração de $\mathrm{A} \beta$. A formação de oligômeros de $\mathrm{A} \beta$ pode inibir diretamente a potencialização de longo prazo do hipocampo através da interação com os receptores de membrana dos neurônios, podendo portanto corromper a plasticidade sináptica. Além disso, a agregação e o depósito de $\mathrm{A} \beta$ no cérebro causam stress oxidativo e respostas inflamatórias, o que também prejudica transmissões sinápticas, resultando em déficits de neurotransmissão. A formação dos emaranhados da proteína Tau é considerada uma consequência de eventos de acordo com essa hipótese, mas que também contribui para uma disfunção neuronal e declínio cognitivo.

FONTE: Adaptada de Blennow et al. 2006.

\subsection{Quadro clínico e diagnóstico}

A DA é uma doença progressiva de evolução lenta, com início insidioso, caracterizada por um declínio cognitivo gradual. Estima-se que seu processo de neurodegeneração ocorra entre 20 a 30 anos antes do surgimento dos primeiros sintomas clínicos (Davies et al., 1988). A fase pré-clínica da doença é marcada por um comprometimento cognitivo leve (CCL), o qual é definido com base em informações subjetivas de perda de memória fornecidas pelo 
cuidador primário e também por critérios objetivos como idade e nível de escolaridade (Gauthier et al., 2006). Estudos sugerem que um CCL amnéstico possa representar um estágio transicional entre um envelhecimento cerebral normal e a DA (Petersen 2004). No entanto, muitos pacientes com esta condição apresentam achados neuropatológicos que correspondem a DA e, portanto, estariam apresentando os sintomas inicias da doença; além disso estima-se que, por ano, 10-15\% dos pacientes com CCL amnéstico evoluam para a DA (Petersen 2004).

O diagnóstico clínico da DA é feito a partir da constatação do declínio cognitivo do paciente através de avaliações psiquiátricas juntamente com exames de neuroimagem que venham a excluir causas alternativas de demência como tumor cerebral, hematoma subdural ou doença cerebrovascular (Blennow et al., 2006). É importante ressaltar que mesmo havendo critérios clínicos para o diagnóstico da DA, estes não atingem níveis fidedignos quanto a sua sensibilidade e especificidade, principalmente na fase inicial da doença. Os melhores escores clínicos disponíveis até o momento apresentam aproximadamente $85 \%$ de correlação com os critérios neuropatológicos usados para definir a DA (McKeel et al., 2004). Dessa forma, para um diagnóstico definitivo da doença ainda é necessária uma comprovação histopatológica post mortem das lesões cerebrais que caracterizam a DA.

\section{Desequilíbrios genômicos - variações no número de cópias de segmentos de DNA} (Copy number variation - CNV)

O genoma humano apresenta variações presentes em diversas formas, incluindo variações em sequências únicas, em número de sequências repetitivas e em estruturas genômica.

Com relação às variações cromossômicas estruturais, estas são usualmente definidas como alterações genômicas que envolvem segmentos de DNA, podendo ser microscópicas ou submicroscópicas (Feuk et al., 2006). Variações estruturais, grandes o suficiente para serem vistas sob um microscópio, quase sempre são resultados de acidentes patogênicos isolados e não fazem parte da variação humana normal. No entanto, os citogeneticistas reconhecem três tipos relativamente comuns de variações estruturais microscópicas na população: (1) heteromorfismos, (2) sítios frágeis e (3) variação de tamanho e morfologia dos braços curtos dos cromossomos acrocêntricos (cromossomos 13, 14, 15, 21 e 22) (Feuk et al., 2006). Porém, com o avanço da biologia molecular e o desenvolvimento de novas tecnologias tornou-se possível detectar variações estruturais menores e mais abundantes no genoma humano. Tais alterações, classificadas como submicroscópicas, incluem inversões, 
duplicações segmentais, translocações, inserções, dissomia uniparental segmental e também podem fazer parte da variação genética humana normal (Sharp et al., 2006).

Há alguns anos atrás, em 2004, um novo tipo de desequilíbrio genômico estrutural foi descoberto a partir dos resultados de duas investigações independentes sobre o número de cópias de DNA em indivíduos saudáveis (Iafrate et al., 2004; Sebat et al., 2004). Esses dois estudos pioneiros demonstraram que muitos segmentos grandes de DNA (100 kilobases [Kb] $\mathrm{a} \geq 2$ megabases $[\mathrm{Mb}]$ ) variavam em número de cópias entre os indivíduos da população geral, demonstrando claramente a existência de grandes diferenças entre os genomas desses indivíduos. A esse novo tipo de variação estrutural deu-se o nome de Copy Number Variation - $\mathrm{CNV}$, variação no número de cópias de segmentos de DNA.

CNVs são operacionalmente definidas como segmentos de DNA maiores que $1 \mathrm{~Kb}$, com um número de cópias variável quando comparado a um genoma referência (Lee et al., 2007a). Contudo, é importante ressaltar que com o avanço de novas tecnologias, CNVs menores que um $1 \mathrm{~Kb}$ já foram e são documentadas, mas essa definição ainda é mantida, pois ajuda na distinção de um outro tipo diferente de mutação que são os SNPs de inserção e deleção. Desde sua descoberta, as CNVs vem sendo documentadas em banco de dados como o Database of Genomic Variant (http://dgv.tcag.ca/dgv/app/home) que cataloga variações estruturais no genoma de indivíduos controle da população e que estariam relacionadas com variantes "comuns", e o DECIPHER - Database of Chromosomal Imbalances and Phenotype in humans using Ensembl Resources (http://www.sanger.ac.uk/PostGenomics/decipher), responsável por fazer uma compilação de dados sobre desequilíbrios genômicos associados à fenótipos com importância clínica, o que corresponderiam à variantes raras na população. Esta sistematização de informações que integra muitos grupos de pesquisa representa uma ferramenta importante para os geneticistas e já possibilitou a descrição de novas síndromes, como a de microdeleção 17q21.3 (Koolen et al., 2008; Shaw-Smith et al., 2004) e as síndromes de duplicação/deleção recíprocas de 16p13.1 (Ullmann et al., 2007).

\subsection{Características das CNVs}

Uma mudança no número de cópias de segmentos de DNA requer uma alteração estrutural cromossômica, unindo duas sequências de DNA anteriormente separadas; as junções dos pontos de quebra das CNVs fornecem pistas importantes sobre como uma determinada mudança estrutural surgiu, ajudando a caracterizar as CNVs (Stankiewicz e Lupski 2010). Muitas alterações estruturais apresentam pontos de quebra recorrentes, ou seja, a maioria dos eventos ocorre e estão confinadas a determinados segementos genômicos. As 
junções dessas CNVs recorrentes geralmente acontece nas regiões com baixo número de cópias (low copy repeats - LCRs), também chamadas de duplicações segmentais (Arlt et al., 2012; Liu et al., 2012). Geralmente, as CNVs recorrentes correspondem a inversões ou deleções e duplicações recíprocas. Por outro lado, existem também CNVs com pontos de quebra único, não recorrentes; a maioria desses desequilíbrios genômicos ocorrem em locais de homologia limitada a 2-15 pb. Além disso, duplicações, triplicações, inversões, inserções, deleções e translocações podem resultar nesse tipo de CNV (Arlt et al., 2012; Liu et al., 2012). Outra característica importante é que embora as junções das CNVs não recorrentes não coincida com regiões com baixo número de cópias, elas tendem a ocorrer nas proximidades dessas regiões, tanto em repetições diretas quanto invertidas, resultando em uma arquitetura genômica complexa. Se enquadram nessa categoria, a maioria das CNVs não associadas a fenótipos clínicos e uma grande porcentagem de CNVs patogênicas (Stankiewicz e Lupski 2010).

\subsection{Mecanismos de formação das CNVs}

Em geral, os dois mecanismos mais comuns que podem dar origem a desequilíbrios genômicos são: recombinação homóloga não alélica (Non-Allelic Homologous Recombination - NAHR) e recombinação não homóloga.

Considerado o principal mecanismo a dar origem às CNVs recorrentes, NAHR requer uma extensa identidade de sequência de DNA e é tipicamente mediado por grandes desalinhamentos de duplicações segmentais ou por sequências repetitivas (Gu et al., 2008; Stankiewicz e Lupski 2010). As CNVs recorrentes podem, portanto, surgir da mesma maneira como foi elegantemente descrito quase duas décadas atrás para as síndromes de microdeleções/microduplicações (ex.: Charcot-Marie-Tooth e Prader-Willi) (Stankiewicz et al., 2003) (Figura 5A). Adicionalmente, pode ocorrer também uma recombinação entre duplicações segmentais orientadas na mesma direção e resultar em deleções ou duplicações recíprocas ou LCRs com repetições invertidas pode conduzir a inversões de segmentos genômicos intervenientes (Figura 5B).

Com relação aos mecanismos envolvidos na formação das CNVs não recorrentes, até há pouco tempo, muito pouco se sabia sobre a origem desses desequilíbrios genômicos. Acredita-se que erros na replicação do DNA é que dão origem às junções dos pontos de quebra observadas nesse tipo de CNVs (Arlt et al., 2012; Liu et al., 2012). Falhas nos mecanismos de reparo de DNA do tipo recombinação não homóloga são apontados como responsáveis na formação das CNVs não recorrentes. $\mathrm{O}$ mais estudado é a junção de 
extremidades não homólogas (Non Homologous End Joining - NHEJ) que detecta quebras de fita dupla de DNA e une, através da adição ou remoção de alguns pares de base, as extremidades que não estavam contíguas (Gu et al., 2008; Lee et al., 2007b). Além do NHEJ, FoSTeS (Fork Stalling and Template Switching) e replicação induzida por quebra mediada por microhomologia (Microhomology Mediated Break-Induced Replication - MMBIR) são outros dois mecanismos importantes na geração de CNVs não recorrentes e rearranjos genômicos complexos (Lee et al., 2007b; Zhang et al., 2009). FoSTeS baseia-se na correção da duplicação do DNA, interrompida por lesões ou formação de estruturas secundárias; diante da interrupção da forquilha de replicação, a fita atrasada invade outras forquilhas próximas, até completar a duplicação da fita atrasada na forquilha original. A mudança de forquilha exige a presença de microhomologias com os sítios invadidos para o priming da extremidade 3' reiniciar a replicação (Lee et al., 2007b; Zhang et al., 2009). Já MMBIR é derivado do modelo de replicação induzido por quebra, proposto para a explicar a reiniciação da duplicação do DNA em leveduras durante a colisão de forquilhas de replicação e a manutenção telomérica de linhagens celulares humanas que perderam a atividade da telomerase (Lee et al., 2007b; Zhang et al., 2009). MMBIR é iniciado por uma quebra da fita dupla de DNA gerada a partir do encontro de uma forquilha de replicação com uma quebra no DNA de fita simples. Como a quebra da fita dupla de DNA não pode ser reparada por NHEJ, por não haver outra ponta livre à frente, ocorre ressecção da extremidade 5'e exposição de uma ponta 3' overhang, que segundo o modelo MMBIR propõe, pode invadir sucessivas vezes outras regiões de fita única no genoma que compartilham homologia e servir de priming para reiniciar a replicação nestes pontos (Lee et al., 2007b; Zhang et al., 2009).
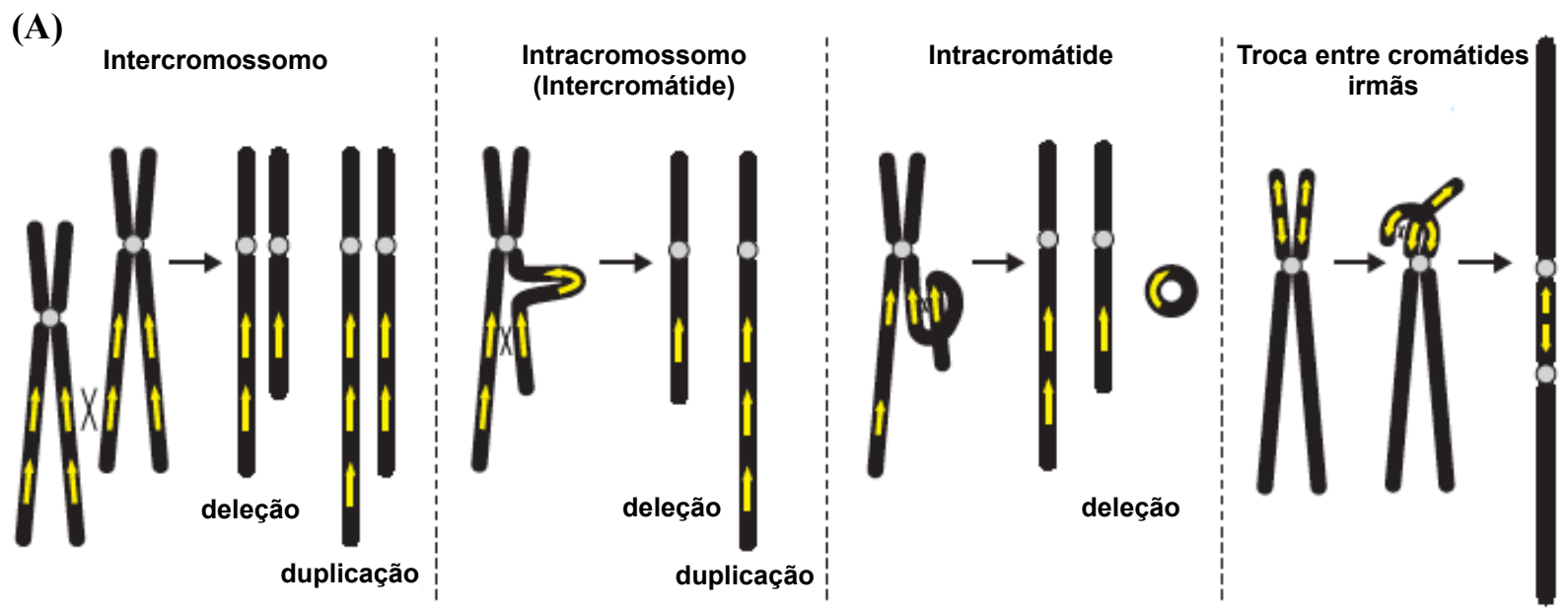
(B)

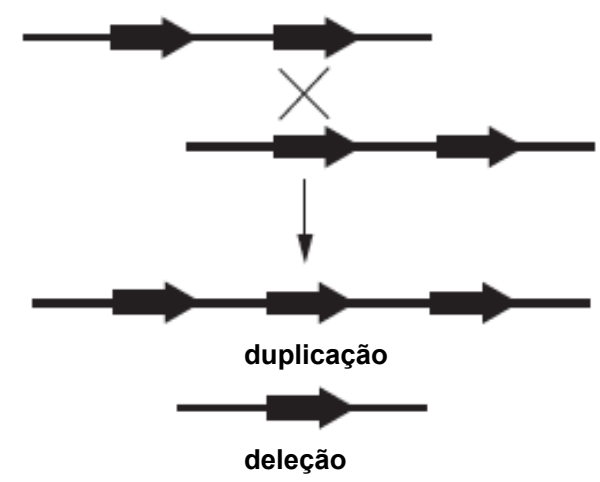

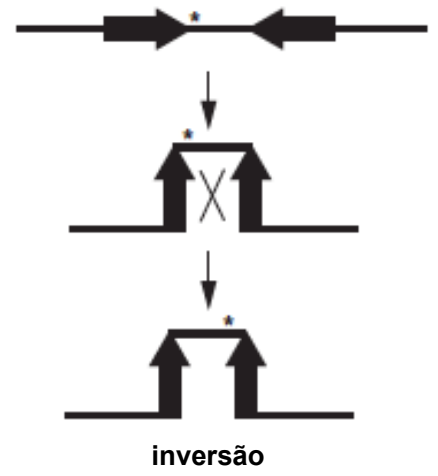

Figura 5. Representação do mecanismo mais comum que dá origem aos desequilíbrios genômicos recorrentes. (A) Recombinação homóloga não alélica (Non-Allelic Homologous Recombination - NAHR) pode gerar deleções ou duplicações através de três maneiras: crossover intercromossomos, intracromossomos e intracromátides. Note que a recombinação intracromátides só gera deleções e não duplicações. NAHR quando ocorre entre duplicações segmentais invertidas nas cromátides irmãs também pode resultar na formação de isocromossomos. (B) Duplicações segmentais orientadas na mesma direção pode resultar em deleções ou duplicações recíprocas, além disso duplicações segmentais com repetições invertidas pode conduzir a inversões de segmentos genômicos intervenientes

FONTE: Adaptada de Liu et al., 2012.

\subsection{Como as CNVs podem impactar um fenótipo}

Dados da literatura estimam que 5 a 20\% do genoma reside em CNVs ordenadas em segmentos que podem abranger até milhões de pares de base e incluir genes completos e elementos regulatórios (Henrichsen et al., 2009; Lee et al., 2007a). Embora algumas variantes em determinadas regiões genômicas possam não ter consequência alguma no fenótipo, outras sabidamente estão associadas a quadros clínicos importantes. Existem diversas formas pelas quais um desequilíbrio genômico pode impactar diretamente um fenótipo (Stankiewicz e Lupski 2010). Talvez a mais óbvia seja a interrupção de genes ou elementos reguladores causada por deleções ou duplicações. A expressão de genes situados próximos aos pontos de quebra também pode ser alterada devido ao "efeito de posição"; nesse caso o rearranjo não altera diretamente o gene ou sua região promotora, mas a mudança de posição pode separar o gene de um elemento regulador ou pode aproximá-lo da região reguladora de outro gene (Hurles et al., 2008). Além disso, uma CNV pode modificar os níveis de expressão gênica por alterar o número de cópias de genes sensíveis a alteração de dose (Henrichsen et al., 2009), ou revelar mutações recessivas ou polimorfismos funcionais do alelo remanescente quando uma deleção ocorre (como exemplificado a seguir). É importante ressaltar que existem também dois fatores importantes que ajudam os geneticistas a discernir a relevância de uma CNV para o fenótipo investigado: a frequência dos desequilíbrios genômicos e o tipo de herança.

Historicamente, assim como as alterações cromossômicas, a suposição é que, no caso de uma variação rara, o evento tem que ser de novo para explicar a presença do fenótipo na 
criança afetada que possui genitores normais; enquanto que as variantes "comuns" seguem um padrão de herança mendeliano e são mais frequentes na população (Lee et al., 2007a). Porém, sabemos que algumas variações raras se comportam como um fator de predisposição, como ilustrado pelo trabalho de Klopocki e colaboradores, no qual foram estudados 30 pacientes afetados pela síndrome de Trombocitopenia-Aplasia Radial (TAR) que tem por característica filhos afetados nascerem de pais normais, e os resultados mostraram deleções variáveis em 1q21 presentes em todos os pacientes e que incluíam um segmento em comum de $200 \mathrm{~Kb}$ contendo 11 genes. Embora, a deleção dessa região não tivesse sido documentada no Database of Genomic Variant como variante normal, em $75 \%$ dos pacientes a deleção havia sido herdada de um genitor normal (Klopocki et al., 2007). Na continuação dos estudos sobre a TAR, ficou evidente que a manifestação do quadro clínico era dependente então de uma herança composta por um alelo nulo raro mais um SNP de baixa frequência nas regiões regulatórias do gene RBM8A presente no alelo não deletado (Albers et al., 2012). Em um outro manuscrito investigando a síndrome de Peter Plus, uma deleção no cromossomo 13 foi identificada em dois irmãos e em vários parentes não afetados. O sequenciamento nos pacientes dos genes mapeados no segmento deletado revelou uma mutação patogênica no alelo não deletado do gene B3GALTL, o que levou à descoberta de que este gene, assim como o $R B M 8 A$, apresenta uma mutação com padrão de herança autossômico recessivo (Lesnik Oberstein et al., 2006).

\subsection{CNVs e doença de Alzheimer}

A partir da descoberta da existência de CNVs no genoma humano, é crescente o número de trabalhos demonstrando o papel crítico das mesmas nos fenótipos de doenças complexas. No entanto, apesar de existirem alguns GWAS com CNVs na DA, com exceção dos trabalhos que reportam variações em $A P O E, C R 1$ e $A P P$ (genes que reconhecidamente possuem papel importante na doença) (Brouwers et al., 2012; Chapman et al., 2013), até hoje os estudos na literatura documentaram variantes comuns na população que estavam ausentes nos controles e enriquecida nos pacientes com DA (Heinzen et al., 2010; Swaminathan et al., 2012a; Swaminathan et al., 2011; Swaminathan et al., 2012b). Chapman e colaboradores no estudo de associação com a maior casuística já estudada concluíram que desequilíbrios genômicos possivelmente possuem uma contribuição limitada no risco de desenvolver DA (Chapman et al., 2013). Contudo, um manuscrito publicado pelo Wellcome Trust Consortium mostra que a associação entre manifestações fenotípicas e inúmeras variantes estruturais (não selecionadas por tamanho ou conteúdo gênico) é provavelmente estatisticamente tão 
complicada quanto a de SNPs, exigindo enormes estudos para modestos resultados em termos de significância (Consortium 2007). Por outro lado, Komura e colaboradores evidenciaram a correlação entre o tamanho das CNVs e seu impacto fenotípico, mostrando que quanto maior a variação estrutural mais provável que esta influencie de maneira significativa uma manifestação clínica (Komura et al., 2006). Variantes de tamanho considerável ( $>50 \mathrm{~Kb})$ estão presentes em indivíduos normais em uma média de 7 CNVs por pessoa (dados não publicados de controles do nosso laboratório), um número modesto em comparação à quantidade de dados gerados pelos GWAS. A investigação de um pequeno número de variantes, selecionadas por conteúdo gênico e tamanho, em indivíduos apresentando fenótipos “extremos" (pouco frequentes na população geral), representa uma abordagem para se detectar alterações raras causativas do fenótipo avaliado. Porém, este modelo que muitos grupos de pesquisa têm usado para trabalhar com CNVs, ainda não foi utilizado para detectar desequilíbrios genômicos importantes na DA.

\section{Epigenética: metilação do DNA}

O termo epigenética refere-se ao estudo das mudanças hereditárias na expressão gênica que independem de alterações na sequência do DNA. Os principais mecanismos que modificam os padrões de expressão gênica e/ou transmitem essas alterações durante a divisão celular são: (1) metilação do DNA; (2) modificações pós-traducionais das proteínas histonas e remodelamento da cromatina; (3) mecanismos baseados em RNA não codificadores (Gibney e Nolan 2010). No entanto, o mecanismo epigenético mais bem caracterizado até hoje é a metilação do DNA, que envolve a adição de um grupo metil ao carbono número 5 do anel de pirimidina de citosina (5-metilcitosina) (Figura 6). Estudos demonstram que a metilação do DNA ocorre preferencialmente nas citosinas que tem como nucleotídeo o vizinho a guanina no sentido downstream - as chamadas sequências $\mathrm{CpG}^{2}$ (Newell-Price et al., 2000).

Tipicamente, a metilação do DNA está associada com silenciamento e inativação gênica, podendo afetar a transcrição basicamente de duas maneiras: impedindo fisicamente a ligação de fatores de transcrição nos genes; e/ou recrutando, através da ação das proteínas de ligação a metil-CpG (MBDs), componentes epigenéticos ao locus, como por exemplo histonas deacetilases e outras proteínas remodeladoras da cromatina, fazendo que ocorra uma compactação da cromatina (Robertson 2005). Sob condições normais, a metilação do DNA

\footnotetext{
${ }^{2}$ Embora trabalhos recentes demonstram a existência de metilação em regiões não-CpG em humanos (CHG e $\mathrm{CHH}, \mathrm{H}$ podendo ser $\mathrm{A}, \mathrm{C}$ ou T), a função e o mecanismo responsáveis por esse novo tipo de metilação ainda permanecem desconhecidos.
} 
ocorre predominantemente nas regiões repetitivas do genoma, incluindo DNA satélite, elementos longos dispersos transponíveis (long interspersed transposable elements - LINEs), elementos curtos dispersos transponíveis (short interspersed transposable elements - SINEs) e retrovírus endógeno, mas também ocorre esporadicamente no corpo de genes, tanto em íntrons quanto em éxons, e nas sequências intergênicas (Portela e Esteller 2010). É importante ressaltar que além de seu importante papel na inativação da expressão gênica, a metilação do DNA nas sequências repetitivas surge também como um potente mecanismo na manutenção da estabilidade genômica, uma vez que impede eventos de recombinação indesejáveis, os quais poderiam causar instabilidade cromossômica com a ocorrência de translocações, rompimento e desregulação transcricional de genes vizinhos (Portela e Esteller 2010). Adicionalmente, a metilação do DNA também desempenha um papel fundamental no imprinting genômico, fenômeno em que ocorre uma expressão monoalélica de certos genes, devido a uma hipermetilação em um dos alelos de acordo com a origem parental (Kacem e Feil 2009). Uma redução de dosagem gênica similar ao imprinting é igualmente observada na inativação do cromossomo $\mathrm{X}$ em fêmeas, mecanismo que resulta em um balanceamento da quantidade de produtos gênicos nos dois sexos (Reik e Lewis 2005).

(A)<smiles>Nc1cc[nH]c(=O)n1</smiles><smiles>CC(C)C(C)(C)C(C)C</smiles>

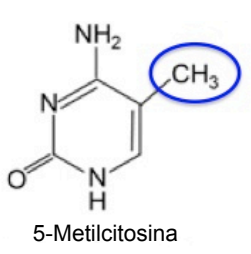

(C)

(B)
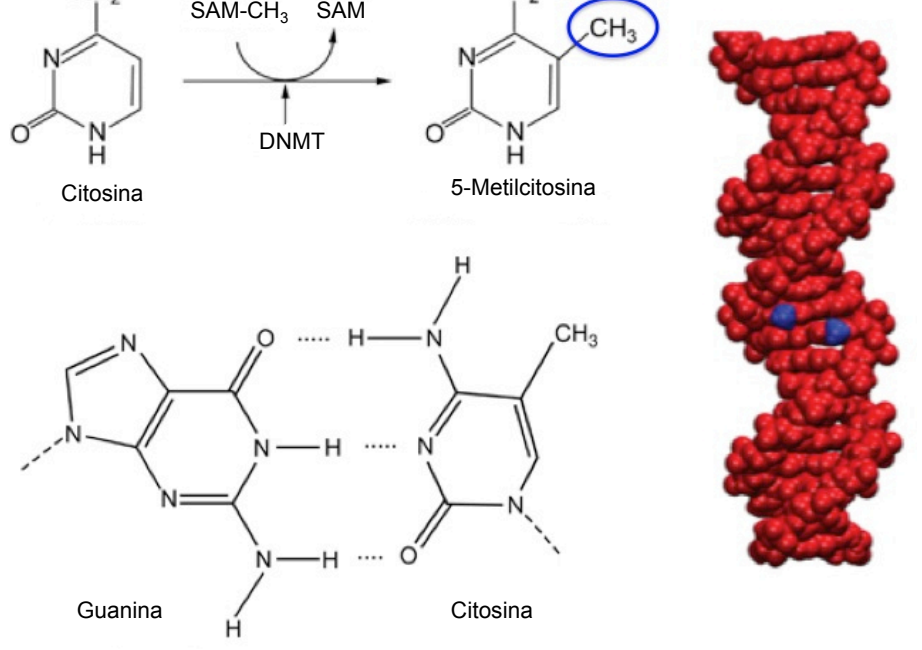

Figura 6. 5-Metilcitosina. (A) Conversão de citosina em 5-metilcitosina pela ação da família de enzimas DNA metiltransferase (DNMT). DNMT catalisa a transferência do grupo metil (CH3) da S-adenosilmetionina (SAM) ao carbano número 5 do anel de pirimidina de citosina. (B) Pareamento entre 5-metilcitosina e o nucleotídeo guanina. (C) Os grupos metil (em azul) encontram-se no sulco maior da dupla hélice da molécula de DNA.

FONTE: Adaptada de Gibney e Nolan, 2010.

A metilação do DNA é mediada pela família de enzimas DNA metiltransferases (DNMTs) que catalisam a transferência do grupo metil da S-adenosil metionina à molécula de 
DNA e são responsáveis por estabelecer e manter o padrão de metilação do DNA (Bergman e Cedar 2013). Em mamíferos, foram descritos cinco membros da família DNMT: DNMT1, DNMT2, DNMT3A, DNMT3B e DNMT3L, porém somente DNMT1, DNMT3A e DNMT3B possuem atividade metiltransferase. DNMT3A e DNMT3B são de novo metiltransferase, ou seja, elas podem metilar qualquer sequência $\mathrm{CpG}$ e por serem altamente expressas nas células tronco embrionárias e downregulated nas células já diferenciadas acredita-se que sejam responsáveis por estabelecer o padrão de metilação durante o desenvolvimento embrionário (Subramaniam et al., 2014). Já a DNMT3L apesar de não possuir atividade catalítica, se faz necessária para estabelecer o imprinting genômico; muito expressa durante a gametogênese, atua como um fator estimulatório para DNMT3A e DNMT3B, interagindo e se co-localizando com as de novo DNMTs no núcleo (Subramaniam et al., 2014). Com relação a DNMT1, apesar de também possuir atividade DNMT de novo, esta apresenta 30 a 40 vezes mais afinidade pelas sequências $\mathrm{CpG}$ hemimetiladas que surgem durante a replicação semiconservativa do DNA. Quando o DNA contendo uma sequência CpG metilada é replicado, a CpG na nova fita complementar inicialmente não está metilado. A DNMT1 portanto é responsável por metilar especificamente essas sequências $\mathrm{CpG}$ não metiladas que estão pareadas com CpG metilada (Portela e Esteller 2010). A manutenção da metilação é o principal (ou pelo menos o mais compreendido) mecanismo de memória epigenética; ela permite que o padrão de metilação do DNA seja mantido intacto durante a replicação do DNA e transmitido durante a divisão celular para as células filhas.

\subsection{Ilhas CpG}

O DNA, sendo composto por 4 nucleotídeos (A, T, C e G), possui 16 possibilidades de formação de dinucleotídeos. O pareamento $\mathrm{CpG}$ ocorre em uma frequência menor do que o esperado na maior parte do genoma, porém em uma frequência maior em regiões chamadas de ilhas CpG (IsCG) (Gibney e Nolan 2010). Definidas como regiões de no mínimo 200 pb, com um conteúdo de $\mathrm{G}+\mathrm{C}$ maior do que $50 \%$ e uma razão de $\mathrm{CpG}$ entre as frequências observada e esperada de pelo menos $60 \%$, as IsCG encontram-se desmetiladas ou possuem níveis relativamente baixos de metilação, sendo quase sempre relacionadas com a ativação da expressão gênica (Illingworth e Bird 2009). Além disso, as IsCG encontram-se distribuídas desigualmente por todo o genoma e sobrepõem as regiões promotoras da maioria dos genes, sendo associadas principalmente a genes expressos constitutivamente, sendo que aproximadamente $40 \%$ desses genes exibe um perfil de expressão tecido-específico (Robertson 2005). 
Até pouco tempo atrás, a maioria dos trabalhos sobre metilação do DNA focava exclusivamente nas IsCG situadas nos sítios de início de transcrição (SIT), porém com o desenvolvimento de novas tecnologias que atualmente permitem uma análise global sobre o perfil de metilação em diferentes condições é que começamos a compreender melhor como a posição da metilação na unidade transcricional influencia sua relação com o controle gênico. Hoje sabemos por exemplo que as IsCG podem estar associadas não somente a regiões promotoras, mas também podem estar localizadas intragenicamente, nos corpos dos genes, ou em locais intergênicos, como nos sítios amplificadores no genoma (Jones 2012).

\subsubsection{Funções da metilação do DNA das IsCG nos sítios de início de transcrição, no corpo de genes e em outros sítios regulatórios}

\subsubsection{Sítios de início de transcrição (SIT)}

Padrões de metilação nos sitios de transcrição das ilhas CpG (IsCG)

A grande maioria das IsCG encontram-se desmetiladas nas células somáticas, favorecendo a expressão gênica. Os genes que possuem IsCG desmetiladas nos seus promotores, quando ativos, apresentam regiões livres de nucleossomos (nucleosome-depleted regions - NDR) no sítio de início de transcrição (SIT) (Jones 2012). Os nucleossomos que circundam o SIT geralmente são caracterizados por uma trimetilação da histona H3 na lisina 4 (H3K4me3) e pela presença da variante de histona H2A.Z (Figura 7). Esta atua como uma antagonista das enzimas DNMTs, impedindo a metilação do DNA, enquanto H3K4me3 é comumente associada com a ativação da transcrição gênica (Jones 2012). No entanto, embora pouco frequente, algumas IsCG encontram-se metiladas no genoma humano e estão associadas com o silenciamento da expressão gênica. Em geral, as IsGC metiladas estão presentes em genes que possuem um papel importante na estabilização a longo prazo de estados repressores, como por exemplo em genes imprintados, genes localizados no cromossomo $\mathrm{X}$ inativo e genes que são expressos exclusivamente nas células germinativas em que presume-se que sua expressão seja inapropriada nas células somáticas (Kacem e Feil 2009).

Relação entre a transcrição gênica e a metilação de novo

Evidências recentes sugerem que o processo de metilação de novo, mediado pelas DNMTs (DNMT3A e DNMT3B), necessita da presença de nucleossomos para ser desencadeado (Ooi et al., 2007). O trabalho de You e colaboradores foi um dos pioneiros em 
testar o papel dos nucleossomos no desencadeamento do processo de metilação de novo. Os autores estudaram a cinética de silenciamento do gene OCT4 nas células de carcinoma embrionário e demonstraram que na região amplificadora do gene, depois das células se diferenciarem, primeiro um nucleossomo se torna presente, em seguida, acontece o recrutamento da DNMT3A para esse nucleossomo e, subsequentemente, a metilação de novo ocorre (You et al., 2011). Além disso, dados da literatura mostram que é muito pouco provável que a metilação de novo aconteça em nucleossomos que possuem as marcas de acetilação H3Kme2 ou H3K4me3, as quais estão associadas com ativação gênica. É sabido que os nucleossomos que cercam o SIT, onde frequentemente é caracterizado por NDR, contém tanto a marca H3L4me3 e a histona variante H2A.Z, ambas notoriamente não correlacionadas com a metilação do DNA (Zilberman et al., 2008). O estado desmetilado das IsGC é também presumidamente assegurado pela presença da proteína TET1, encontrada em grandes quantidades nos SIT de promotores que possuem alto conteúdo de CpG. Supõe-se que TET1 converta qualquer 5-metilcitosina em 5-hidroximetilcitosina (Williams et al., 2012). Portanto, a anatomia molecular das IsCG ativas pode explicar porque estas são tão resistentes a metilação.

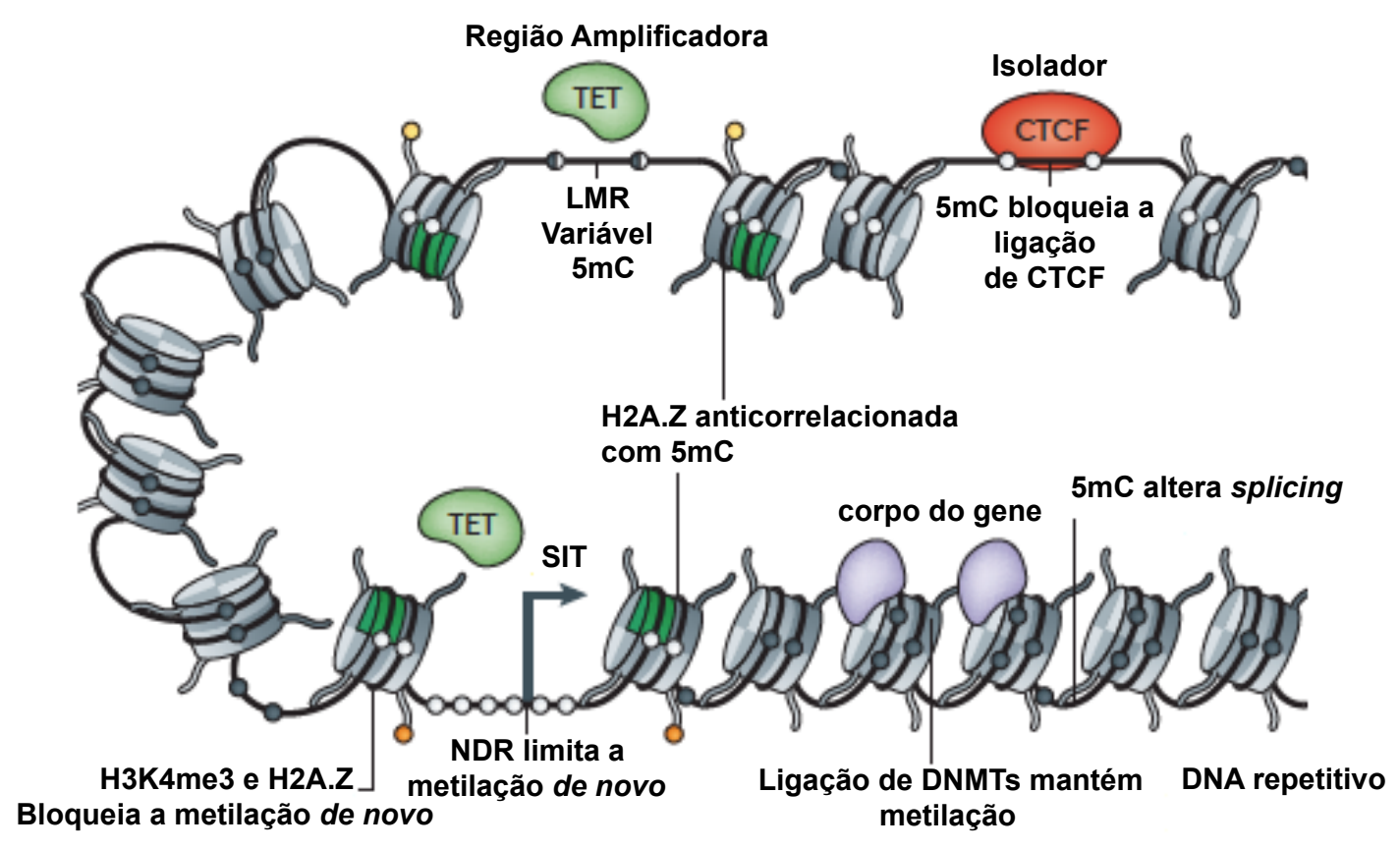

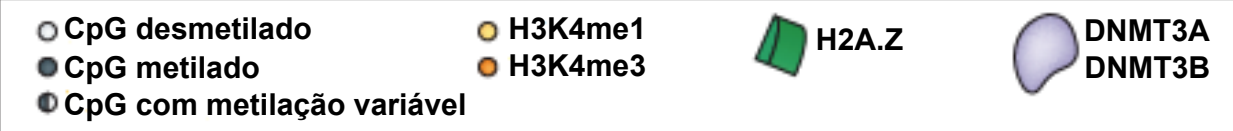

Figura 7. Anatomia molecular dos sítios CpGs na cromatina e seu papel na expressão gênica. Cerca de $60 \%$ dos genes humanos apresentam ilhas CpGs (IsCG) em seus promotores e frequentemente possuem regiões depletadas de nucleossomos (nucleosome-depleted regions - NDR) nos sítios de início de transcrição (SIT). O flanqueamento dos nucleossomos nos SIT são marcados pela trimetilação da histonas H3 na lisina 4 (H3K4me3), 
que é associada com a ativação da transcrição, e pela variante da histona H2A.Z, a qual é antagonista à DNA metiltransferases (DNMTs). No sentido downstream do SIT, o DNA é na maioria das vezes depletado de CpGs e apresenta-se predominantemente metilado nos elementos repetitivos e nos corpos dos genes. As IsGG localizadas nos corpos dos genes normalmente permanecem desmetiladas, porém ocasionalmente podem adquirir uma 5-metilcitocisna de uma maneira tecido-específica. A elongação da transcrição, diferentemente da iniciação, não é bloqueada pela metilação do corpo do gene, e a metilação variável que ocorre nos corpos dos genes pode estar envolvida no controle do splicing alternativo. A metilação do DNA é mantida pela DNMT1 e também pela DNMT3A e/ou DNMT3B, as quais estão ligadas aos nucleossomos contendo DNA metilado. Sítios amplificadores no genoma tendem a ser regiões pobres em CpGs e apresentam metilação incompleta, sugerindo que um processo dinâmico de metilação ou desmetilação possa ocorrer, devido provavelmente à presença de proteínas nessas regiões, como por exemplo a TET (TET-ten-eleven translocation). No entanto, mais estudos são necessários para que essa hipótese seja confirmada. 5-metilcitosina (5-mC); low-methylated regions (LMR), regiões com pouca metilação.

FONTE: Adaptada de Jones, 2012

\subsubsection{Metilação no corpo de genes}

A maioria dos corpos de genes apresentam-se metilados e contém múltiplos elementos transponíveis e sequências repetitivas. A metilação nas sequências $\mathrm{CpG}$ nos éxons é a maior causa de mutações C-T, o que pode levar a mutações causadoras de doenças na linhagem germinativa e/ou mutações nas células somáticas (Jones 2012). É importante ressaltar que embora muitas IsCG estejam localizadas na região promotora dos genes, elas também podem existir dentro do corpo dos genes. Apesar de sua função ainda permanecer desconhecida, Illingworth e colaboradores propuseram que as IsCG dos corpos de genes poderiam representar "promotores órfãos", os quais foram usados durante os estágios iniciais do desenvolvimento e escaparam à metilação na linhagem germinativa, o que então explicaria a alta densidade de CpGs nessas regiões (Illingworth et al., 2010).

\section{Metilação no corpo de genes não está associada com repressão gênica}

Várias evidências apontam para uma correlação positiva entre a ativação da transcrição gênica e a metilação no corpo de genes. É sabido que a maioria dos corpos de genes não são IsCG e, inicialmente, acreditava-se que estas, quando situadas em regiões intragênicas, apresentavam-se sempre como desmetiladas (Larsen et al., 1993). No entanto, novos experimentos vem mudando essa percepção. Por exemplo, cerca de $34 \%$ de todas as IsCG intragênicas estão metiladas no cérebro humano, porém, o papel dessa metilação, que é tecido específica, ainda não está esclarecido (Maunakea et al., 2010). O intrigante é que o SIT desses genes, que possuem metilação em seu corpo, permanecem desmetilados, e mesmo o fato de existir uma extensa metilação no corpo dos genes não bloqueia a elongação da transcrição. Isso leva a um paradoxo em que a metilação no promotor do gene está inversamente correlacionado com a expressão, enquanto que a metilação nos corpos de genes é positivamente correlacionada com a expressão. Portanto, não é simplesmente a presença da 
5-metilcitosina que governa sua relação com a transcrição mas sim a interpretação das marcas em um determinado contexto celular e região genômica em particular (Jones 2012).

Com relação às possíveis funções da metilação nos corpos de genes que ocorre fora de IsCG, além de sua reconhecida função no silenciamento transcricional das sequências intragênicas de DNA repetitivo, estudos globais de metilação sugerem que a metilação do DNA nos corpos dos genes possui um papel importante ao nível transcricional, regulando possivelmente o splicing alternativo (Jones 2012). Dados da literatura mostram que os éxons são mais metilados que os íntrons, e que as transições no nível de metilação ocorre nos limites entre éxons e íntrons (Schwartz et al., 2009). Além disso, indícios sobre o posicionamento dos nucleossomos (os quais sabidamente são sítios preferenciais para a metilação do DNA) no genoma sugerem que os éxons apresentam uma maior ocupação de nucleossomos quando comparados aos íntrons (Chodavarapu et al., 2010). Ainda, um estudo mais recente sugere que a ligação da proteína CTCF (a qual atua como uma repressora transcricional e pode ser regulada pela metilação do DNA) nos elementos chamados isoladores resulta em uma pausa da RNA polimerase II (RNAPII) e, como a cinética do movimento da RNAPII influencia o splicing alternativo, isso também é mais uma evidência que relaciona a metilação do DNA no corpo do gene a esse mecanismo transcricional (Shukla et al., 2011).

Outro aspecto importante relacionado à metilação nos corpos de genes é a constatação de que os mesmos também podem ser SIT. Em geral, assume-se que SIT e corpos de genes são dois aspectos genômicos separados. Porém, a maioria dos genes possui ao menos dois SIT, assim, o SIT downstream estão presentes nos "corpos" das unidades transcricionais dos promotores upstream. Esses promotores alternativos podem ser ou não IsGG, ou pode existir uma combinação de um SIT upstream não-IsCG com um downstream IsCG, ou vice-versa (Jones 2012). Esses sítios alternativos de transcrição dificultam a interpretação de resultados de experimentos que correlacionam expressão gênica com a metilação, pois sondas que são usadas para medir a expressão gênica frequentemente detectam os sinais de todos os promotores, ainda que somente um esteja ativo em um dado tipo celular. A metilação em um promotor downstream iria somente bloquear a transcrição desse promotor, isso permitiria a elongação de um transcrito que emana de um promotor upstream, levando a uma aparente discordância entre metilação e expressão gênica. De fato, a metilação do DNA pode também ser um mecanismo para o controle do uso de promotores alternativos (Maunakea et al., 2010).

\subsubsection{Outros sítios regulatórios}


Regiões amplificadoras (enhancers) são regiões no DNA onde ocorre a ligação de proteínas, como fatores de transcrição, e estão situados a distâncias variáveis de promotores e desempenham um papel chave no controle da expressão gênica, no desenvolvimento e função celular. Em geral, são regiões pobres em $\mathrm{CpG}$ e tendem a ter uma variação grande de metilação (Jones 2012). De fato, Stadler e colaboradores demonstraram que regiões amplificadoras no genoma não estão $100 \%$ metiladas ou desmetiladas e as nomearam lowmethylated regions - LMRs (regiões com pouca metilação). Além disso, os autores sugerem que as sequências $\mathrm{CpG}$ estão num estado dinâmico e que em algum momento apresentam-se metiladas e em outro não, levando a eventos de competição entre metilação e desmetilação (Stadler et al., 2011). Alternativamente, supõe-se que o status de metilação do DNA de cada CpG pode não ser mantido acuradamente durante a divisão celular e, portanto, os estados nas LMRs pode ocorre devido à uma ineficiência em conservar o padrão de metilação do DNA (Jones 2012). Por outro lado, Schmidl e colaboradores também mostraram que existe um número grande de regiões diferencialmente metiladas (differentially methylated regions DMRs) dentro das regiões amplificadoras de genes específicos em diferenciação (Schmidl et al., 2009).

Já a hipótese de que o status de metilação de uma região amplificadora e sua função estejam intimamente ligados é apoiada por várias observações de proteínas que modulam a metilação nessas regiões. Uma análise sobre a ligação do receptor de glicocorticoide a elementos regulatórios distais mostrou que $\mathrm{CpGs}$ podem se tornar desmetiladas e que a região amplificadora pode ser ativada pela presença desse receptor (Jones 2012). No entanto, a relação entre a metilação dos CpG e fatores de transcrição é complexa, sendo assim, mais estudos são necessários para esclarecer os mecanismos pelos quais a metilação nas regiões amplificadoras participa da regulação de fatores de transcrição.

\section{Metilação nos isoladores}

Isoladores podem ser definidos como elementos que bloqueiam a interação entre uma região amplificadora e um promotor. Os exemplos mais bem estudados são as sequências de DNA onde se encontram ligadas as proteínas CTCF. Foi demonstrado que a presença ou a ausência da ligação da proteína CTCF ao locus imprintado IGF2-H19 controla a interação entre região amplificadora e promotor do gene (Jones 2012). Estudos mais recentes mostraram também que a ligação de CTCF ao éxon 5 do gene que codifica o a proteína CD45 é inibida pela metilação do DNA, resultando em efeitos no splicing (Shukla et al., 2011). Porém, estudos globais nas células tronco embrionárias e nas células já diferenciadas de 
camundongos sugerem que a ligação de CTCF não é afetada pelo status de metilação nos sítios de ligação, mas sim que a ligação por si só é responsável por iniciar a desmetilação local (Stadler et al., 2011).

\subsection{Metilação do DNA e Doença de Alzheimer}

Atualmente, é crescente o interesse em investigar como variações epigenéticas, em especial, a metilação no DNA, pode contribuir para o desenvolvimento de doenças complexas. Ao longo dos últimos anos, diversos estudos vêm sugerindo que modificações epigenéticas podem constituir o mecanismo molecular básico e contribuir diretamente para a patogênese da DA. (Iraola-Guzman et al., 2011; Lee e Ryu 2010).

Porém, a grande maioria dos estudos de metilação que foram feitos com a DA são direcionados a genes específicos e, ainda assim, os resultados são inconclusivos (Lu et al., 2013). Com relação a análises globais no padrão de metilação de DNA na DA, o estudo casocontrole de Mastroeni e colaboradores foi o primeiro a demonstrar, através da técnica de imunohistoquímica, que no cérebro de indivíduos com DA existe quantidades significativamente menores de 5-metilcitosina quando comparado aos indivíduos controles (Mastroeni et al., 2010). Além disso, o mesmo grupo de pesquisa também publicou um trabalho com um par de gêmeos monozigóticos discordantes para DA, em que utilizando a mesma técnica, também é possível observar quantidades menores de 5-metilcitosina no cérebro do gêmeo com DA (Mastroeni et al., 2009). Esse indício, de que existe uma tendência de hipometilação global no cérebro com a DA, também ficou evidente em um estudo mais recente, também usando a mesma técnica de análise de imunohistoquímica, onde demonstrouse uma diminuição de 5-metilcitosina no hipocampo de indivíduos com DA (Chouliaras et al., 2013). No entanto, devido à técnica utilizada nos trabalhos referidos, não foi possível atribuir essas diferenças no padrão de metilação do DNA a sequências específicas no genoma.

Mesmo com o advento de novas tecnologias, até hoje só existe um trabalho que utilizou uma plataforma de alta cobertura em que é possível fazer uma análise global do perfil de metilação e ao mesmo tempo identificar a distribuição dos sítios metilados no genoma no cérebro de sujeitos com DA (Bakulski et al., 2012). Porém, vale ressaltar que os dados desse estudo não corroboram com os trabalhos citados anteriormente; Bakulski e colaboradores demonstram que no cérebro com DA existe uma hipermetilação global ao invés de uma hipometilação. Uma hipermetilação global no cérebro com DA também foi reportada em uma outra investigação (Rao et al., 2012). Essa discrepância de resultados foi atribuída a diferença de técnicas usadas nos estudos. Parece claro que existe uma tendência de hipometilação 
global no cérebro com DA quando se utiliza a técnica de imunohistoquímica; já quando o DNA é tratado com bissulfito (método usado nas plataformas de alta cobertura) observa-se um resultado oposto (Lu et al., 2013).

Portanto, sabendo que o estudo de modificações epigenéticas, mais precisamente a metilação do DNA, pode ajudar a compreender as bases genéticas de doenças neurodegenerativas como a DA e, somado a diferença de resultados entre os trabalhos na literatura, mais estudos são necessários para se determinar um padrão de metilação no cérebro com DA e entender a distribuição de sítios metilados de acordo com localização cromossômica, distribuição funcional, etc e sua contribuição na patogênese da doença. 


\section{OBJETIVOS}




\section{OBJETIVOS}

\section{Objetivos Gerais}

Este projeto teve como objetivos principais investigar dois aspectos relacionados à DA: (1) a identificação de variações supostamente constitutivas no número de cópias de segmentos de DNA (CNVs) que podem estar contribuindo para o desenvolvimento da forma multifatorial da DA e (2) alterações do padrão de metilação do DNA no córtex frontal de indivíduos com quadro extremo de manifestação da forma multifatorial da DA.

\section{Objetivos específicos parte I}

1. Investigamos alterações no número de cópias de segmentos de DNA e mapeamos as respectivas regiões cromossômicas, utilizando a técnica de array-CGH, nos indivíduos com um grau moderado a profundo da DA

2. Com base em bancos de dados sobre a variação do número de cópias de segmentos de DNA em indivíduos controle (Database of Genomic Variant - DGV) e afetados (DECIPHER), e nas nossas amostras de sujeitos controle, selecionamos as alterações raras $(<0,1 \%$ menos frequente no DGV) como mais provavelmente relevantes para o quadro clínico investigado

3. Determinamos a possível importância dos genes contidos nos segmentos cromossômicos considerados como causa para os fenótipos analisados

\section{Objetivos específicos parte II}

1. Comparamos os padrões de metilação observados nos grupos controle e DA

2. Determinamos a disposição dos sítios $\mathrm{CpG}$ diferencialmente metilados na DA de acordo com: (1) distribuição genômica funcional: promotor, 3'UTR, região intergênica e corpo do gene e (2) contexto do conteúdo $\mathrm{CpG}$ nas ilhas e áreas adjacentes (shore, shelf e open sea)

3. Identificamos redes de interação molecular entre os genes considerados diferencialmente metilados na DA 
III. CASUÍSTICA E MÉTODOS 


\section{CASUÍSTICAS E MÉTODOS}

Todas as amostras de DNA utilizadas neste projeto foram obtidas post mortem e nos foram concedidas pelo Banco de Encéfalos Humanos do Grupo de Estudos em Envelhecimento Cerebral (BEHGEEC) da Faculdade de Medicina da USP (FMUSP) (Grinberg et al., 2007).

O BEHGEEC foi criado em 2004 com o intuito de realizar um grande número de autópsias em pessoas idosas e fornecer material de alta qualidade para uma rede de pesquisa multidisciplinar que tem por objetivo esclarecer múltiplos aspectos dos processos de envelhecimento cerebral e doenças neurodegenerativas. A idade mínima para fazer parte da amostra do BEHGEEC é 50 anos e todos os casos são provenientes do Serviço de Verificação de Óbitos (SVO) da capital de São Paulo, onde são realizadas todas as autópsias de mortes naturais e sem causa definida. Cerca de 8.000 necropsias por ano são efetuadas em pessoas acima de 50 anos e hoje o BEHGEEC reúne um grande acervo de amostras encefálicas disponíveis para pesquisa.

O status clínico e funcional dos participantes do banco é baseado em informantes. Na chegada do cadáver ao SVO, caso o sujeito atenda aos critérios de seleção, a natureza do projeto é explicada ao responsável pelo falecido e lhe é apresentado o Termo de Consentimento Livre e Esclarecido, aprovado pela Comissão de Ética em Pesquisa da FMUSP. No caso de aceite, o cuidador mais indicado é identificado para obtenção de informações confiáveis, dando preferência ao cuidador primário. Nos casos de indivíduos sem cuidadores primários, a escolha é feita a partir da identificação do familiar com maior convivência com o falecido (contato de no mínimo uma vez por semana). Todo esse procedimento é realizado por uma equipe treinada e coordenada por um gerontólogo. Para a avaliação dos aspectos cognitivos, comportamentais, funcionais e sócio-econômicos dos sujeitos são utilizados questionários compostos por escalas validadas e amplamente utilizadas mundialmente. Os instrumentos usados e seus respectivos domínios de avaliação estão listados no Quadro 1. Além disso, informações sobre o histórico de saúde da pessoa em vida, como as comorbidades apresentadas, os antecedentes pessoais, uso de medicações, fatores de risco cardiovascular e as condições funcionais próximas ao momento de sua morte também são colhidas. 
Quadro 1. Domínios avaliados na entrevista clínica e as respectivas escalas utilizadas.

\begin{tabular}{|c|c|}
\hline Domínio & Escalas utilizadas \\
\hline Cognitivo & CDR-Clinical Dementia Rating Scale (Morris 1993) \\
\hline Comportamental & NPI- Neuropsychiatric Inventory (Cummings et al., 1994) \\
\hline Funcional & $\begin{array}{c}\text { Índice de Katz (Katz et al., 1994) e Escala de Atividades } \\
\text { Instrumentais da Vida Diária (Lawton e Brody 1969) }\end{array}$ \\
\hline Sintomas Parkinsonismo & Escala de Parkinsonismo (Tanner et al., 1990) \\
\hline Distúrbios afetivos & SCID para mania e depressão (Spitzer et al., 1992) \\
\hline Condições sócio-econômica & ABIPEME (Almeida e Wickerhauser 1991) \\
\hline
\end{tabular}

FONTE: Adaptada de Grinberg et al., 2007.

Os procedimentos anatomopatológicos são baseados nos dois protocolos mais aceitos para o estudo de demência: Consórcio para Estabelecer um Registro para a Doença de Alzheimer - CERAD (Mirra et al., 1991) e Braak (Braak e Braak 1991), usados para determinar as presenças de depósitos extracelulares de placas de proteína $\beta$ amiloide e emaranhados de proteína Tau hiperfosforilada, respectivamente. O diagnóstico é feito através da aferição do peso e volume cerebral e amostras de doze regiões do encéfalo (giros frontais e temporais, lobo parietal, córtex de associação visual, giro cingulado anterior, hipocampo, amígdala, gânglios da base, mesencéfalo, ponte, bulbo e cerebelo) são coletadas e embebidas em blocos de parafina para a análise histopatológica. Cortes de 5 a $8 \mu \mathrm{m}$ de espessura são corados pela técnica de rotina hematoxilina-eosina e imunocorados por tissue microarray para as proteínas ubiquitina, tau, beta-amilóide e alfa-sinucleína. A avaliação microscópica segue os critérios de estágios de Braak (0 a 6), onde é levado em consideração o grau e a progressão das lesões, principalmente dos emaranhados neurofibrilares, nas diferentes regiões do cérebro. Em resumo, nos estágios 1 e 2 há envolvimento de lesões no córtex entorrinal e hipocampo, marcando o início da doença; em associação com dados clínicos, nessa fase podem aparecer os primeiros sintomas bastante inespecíficos, como discreta redução da memória, não notável e sem comprometimento das atividades diárias. Nos estágios 3 e 4, há o envolvimento do lobo límbico e neocórtex e clinicamente nota-se prejuízo de memórias de longo-prazo e outros processos cognitivos como julgamento, raciocínio abstrato, cálculo e habilidades 
visuoespaciais. Há também dificuldade em reconhecer pessoas, objetos e escolha da palavra certa para nomeá-los (anomia). Por fim, nos estágios 5 e 6, há completo envolvimento do neocórtex, e perda total da sequência lógica da fala, déficit motor, alteração do ciclo sono/vigília, agitação, irritabilidade e dependência total de um cuidador para realizar as atividades diárias (Braak e Braak 1991).

Contamos com a colaboração das Dras. Lea Grinberg, neuropatologista, e Claudia Suemoto, geriatra, que participam do BEHGEEC, para a classificação e seleção de todas as amostras. Vale destacar que nenhum teste genético em busca de mutações nos genes responsáveis por causar a forma familial da DA é realizado para o diagnóstico da doença no BEHGEEC. Logo, a classificação das amostras de DA deste estudo foi feita por exclusão baseando-se no histórico familiar, na idade de manifestação, no status clínico e funcional, além do diagnóstico neuropatológico do indivíduo. A seguir, detalhamos os critérios de escolha das amostras de cada estudo deste projeto.

\section{Casuísticas}

1.1. Parte I. Estudo sobre a investigação de variações no número de cópias de segmentos de DNA (CNVs) na Doença de Alzheimer (DA)

Para este estudo, utilizamos DNA extraído de sangue ou cerebelo, dependendo da disponibilidade de cada amostra. Com relação à extração de DNA do sangue dos indivíduos, esta foi feita por método robotizado no Centro de Estudos do Genoma Humano da USP (Miller et al., 1988). Já no caso das amostras de cerebelo, a extração do DNA foi feita por fenol-clorofórmio em nosso laboratório (vide seção Métodos).

\subsubsection{Critérios de seleção das amostras para este estudo:}

a) Grupo Doença de Alzheimer (DA): levando em consideração os estágios de Braak, selecionamos os sujeitos que apresentassem um grau moderado (3 e 4) a profundo (5 e 6) da doença. Logo, 46 indivíduos com a forma multifatorial da DA foram investigados por arrayCGH. A Tabela 1 descreve em detalhes todos os casos, com informações sobre estágios de Braak, CERAD e CDR dessas amostras.

b) Grupo Controle: usamos como controle, indivíduos pareados por idade e sexo ao grupo DA. Portanto, foram selecionados 49 sujeitos, homens e mulheres, entre 50 e 97 anos, sem histórico de demência e sem alterações neuropatológicas que preenchesse nenhum critério de qualquer doença neurodegenerativa (Tabela 2). 
A Figura 8 mostra um gráfico sobre a distribuição da frequência das amostras controle e DA e seus respectivos valores correspondentes aos estágios de Braak.

Tabela 1. Descrição de todos os casos do grupo Doença de Alzheimer para o estudo sobre a investigação de variações no número de cópias de segmentos de DNA (CNVs).

\begin{tabular}{|c|c|c|c|c|c|}
\hline Caso & Gênero/Idade & Braak & CERAD & CDR & Tipo da amostra \\
\hline $05-11145$ & $\mathrm{~F} / 62$ & 5 & $\mathrm{C}$ & 3 & sangue \\
\hline 08-02682 & $\mathrm{M} / 82$ & 6 & $\mathrm{C}$ & 3 & sangue \\
\hline 08-07207 & $\mathrm{F} / 84$ & 6 & $\mathrm{C}$ & 3 & sangue \\
\hline 09-06787 & $\mathrm{F} / 83$ & 6 & $\mathrm{C}$ & 3 & cerebelo \\
\hline $05-06917$ & $\mathrm{M} / 69$ & 6 & $\mathrm{C}$ & 1 & cerebelo \\
\hline 05-09097 & $\mathrm{F} / 61$ & 3 & 0 & 0,5 & cerebelo \\
\hline 09-08833 & $\mathrm{F} / 82$ & 5 & $\mathrm{C}$ & 0 & sangue \\
\hline 09-08875 & $\mathrm{F} / 94$ & 5 & $\mathrm{C}$ & 0 & sangue \\
\hline 06-11388 & $\mathrm{F} / 83$ & 3 & B & 1 & sangue \\
\hline $07-01224$ & $\mathrm{M} / 81$ & 4 & 0 & 0 & sangue \\
\hline $07-01350$ & $\mathrm{~F} / 80$ & 5 & $\mathrm{C}$ & 3 & sangue \\
\hline 09-02018 & $\mathrm{F} / 81$ & 4 & B & 3 & sangue \\
\hline 09-02704 & $\mathrm{F} / 79$ & 6 & $\mathrm{C}$ & 3 & sangue \\
\hline 09-03738 & $\mathrm{M} / 82$ & 4 & B & 0 & sangue \\
\hline $05-10237$ & $\mathrm{M} / 86$ & 4 & B & 0,5 & sangue \\
\hline $06-04814$ & $\mathrm{~F} / 85$ & 3 & 0 & 1 & cerebelo \\
\hline 07-02025 & $\mathrm{F} / 82$ & 5 & $\mathrm{C}$ & 2 & cerebelo \\
\hline $06-05258$ & $\mathrm{M} / 85$ & 3 & B & 1 & cerebelo \\
\hline 06-01098 & $\mathrm{F} / 93$ & 6 & $\mathrm{C}$ & 3 & cerebelo \\
\hline $06-02564$ & $\mathrm{~F} / 75$ & 6 & $\mathrm{C}$ & 3 & cerebelo \\
\hline 05-11108 & $\mathrm{M} / 80$ & 4 & B & 0,5 & sangue \\
\hline $06-06275$ & $\mathrm{~F} / 92$ & 4 & B & 0,5 & sangue \\
\hline 08-02984 & $\mathrm{F} / 84$ & 4 & B & 0 & sangue \\
\hline $05-05734$ & $\mathrm{M} / 71$ & 4 & $\mathrm{C}$ & 0,5 & cerebelo \\
\hline $05-07456$ & $\mathrm{~F} / 80$ & 6 & $\mathrm{C}$ & 3 & cerebelo \\
\hline $05-08463$ & $\mathrm{~F} / 89$ & 5 & $\mathrm{C}$ & 0,5 & cerebelo \\
\hline 07-08805 & $\mathrm{F} / 80$ & 4 & B & 1 & cerebelo \\
\hline 05-10920 & $\mathrm{F} / 79$ & 5 & $\mathrm{C}$ & 0,5 & cerebelo \\
\hline $07-01345$ & $\mathrm{~F} / 83$ & 6 & $\mathrm{C}$ & 3 & cerebelo \\
\hline 05-02229 & $\mathrm{M} / 86$ & 3 & B & 0 & cerebelo \\
\hline 09-02544 & $\mathrm{M} / 80$ & 5 & $\mathrm{C}$ & 3 & cerebelo \\
\hline $07-03542$ & $\mathrm{~F} / 80$ & 5 & B & 0 & cerebelo \\
\hline 05-03980 & $\mathrm{F} / 81$ & 5 & $\mathrm{C}$ & 2 & cerebelo \\
\hline 07-04495 & $\mathrm{F} / 84$ & 4 & B & 1 & cerebelo \\
\hline $07-05248$ & $\mathrm{~F} / 86$ & 5 & $\mathrm{C}$ & 3 & cerebelo \\
\hline 05-05404 & $\mathrm{F} / 89$ & 4 & $\mathrm{C}$ & 0 & cerebelo \\
\hline $05-05618$ & $\mathrm{~F} / 73$ & 3 & B & 0 & cerebelo \\
\hline $06-05719$ & $\mathrm{~F} / 79$ & 3 & $\mathrm{~B}$ & 3 & cerebelo \\
\hline $05-05915$ & $\mathrm{M} / 84$ & 5 & $\mathrm{C}$ & 3 & cerebelo \\
\hline
\end{tabular}




\begin{tabular}{lcllll}
\hline $05-06494$ & $\mathrm{M} / 75$ & 3 & $\mathrm{~B}$ & 0 & cerebelo \\
$05-06748$ & $\mathrm{~F} / 82$ & 5 & $\mathrm{~B}$ & 2 & cerebelo \\
$05-06882$ & $\mathrm{M} / 77$ & 4 & $\mathrm{C}$ & 3 & cerebelo \\
$05-07285$ & $\mathrm{~F} / 86$ & 5 & $\mathrm{C}$ & 1 & cerebelo \\
$08-07660$ & $\mathrm{M} / 72$ & 6 & $\mathrm{C}$ & 2 & cerebelo \\
$06-10643$ & $\mathrm{M} / 80$ & 3 & $\mathrm{C}$ & 0,5 & cerebelo \\
$05-05933$ & $\mathrm{M} / 77$ & 5 & $\mathrm{~B}$ & 3 & cerebelo \\
\hline
\end{tabular}

Braak = Estágios de Braak; CERAD = Consórcio para Estabelecer um Registro para a Doença de Alzheimer; $\mathrm{CDR}=$ Escala de Demência Clínica.

Tabela 2. Descrição de todos os casos do grupo controle para o estudo sobre a investigação de variações no número de cópias de segmentos de DNA (CNVs).

\begin{tabular}{|c|c|c|c|c|c|}
\hline Caso & Genêro/Idade & Braak & CERAD & CDR & Tipo da amostra \\
\hline 06-01734 & $\mathrm{F} / 72$ & 0 & 0 & 0 & sangue \\
\hline 06-03120 & $\mathrm{F} / 79$ & 0 & 0 & 0 & sangue \\
\hline $06-04562$ & $\mathrm{M} / 70$ & 0 & 0 & 0 & sangue \\
\hline $06-05655$ & $\mathrm{M} / 70$ & 0 & 0 & 0 & sangue \\
\hline 06-08088 & $\mathrm{F} / 84$ & 0 & 0 & 0 & sangue \\
\hline 06-08350 & $\mathrm{M} / 74$ & 0 & 0 & 0 & sangue \\
\hline 07-01282 & $\mathrm{M} / 79$ & 0 & 0 & 0 & sangue \\
\hline $05-06947$ & $\mathrm{~F} / 82$ & 0 & 0 & 0 & sangue \\
\hline 08-01857 & $\mathrm{M} / 59$ & 0 & 0 & 0 & cerebelo \\
\hline 07-01072 & $\mathrm{M} / 66$ & 0 & 0 & 0 & cerebelo \\
\hline $05-10854$ & $\mathrm{M} / 64$ & 0 & 0 & 0 & cerebelo \\
\hline 05-10915 & $\mathrm{M} / 63$ & 0 & 0 & 0 & cerebelo \\
\hline 06-11442 & $\mathrm{M} / 67$ & 0 & 0 & 0 & cerebelo \\
\hline 05-01811 & $\mathrm{F} / 64$ & 0 & 0 & 0 & cerebelo \\
\hline 09-03736 & $\mathrm{F} / 62$ & 0 & 0 & 0 & cerebelo \\
\hline 09-03869 & $\mathrm{F} / 66$ & 0 & 0 & 0 & cerebelo \\
\hline 09-04667 & $\mathrm{F} / 67$ & 0 & 0 & 0 & cerebelo \\
\hline $05-05214$ & $\mathrm{~F} / 69$ & 0 & 0 & 0 & cerebelo \\
\hline 06-03116 & $\mathrm{M} / 74$ & 0 & 0 & 0 & cerebelo \\
\hline 05-04952 & $\mathrm{M} / 70$ & 0 & 0 & 0 & cerebelo \\
\hline 05-05967 & $\mathrm{M} / 74$ & 0 & 0 & 0 & cerebelo \\
\hline 05-05997 & $\mathrm{M} / 72$ & 0 & 0 & 0 & cerebelo \\
\hline 05-06098 & $\mathrm{M} / 79$ & 0 & 0 & 0 & cerebelo \\
\hline 05-06916 & $\mathrm{M} / 77$ & 0 & 0 & 0 & cerebelo \\
\hline 06-07497 & $\mathrm{M} / 74$ & 0 & 0 & 0 & cerebelo \\
\hline $05-11287$ & $\mathrm{~F} / 74$ & 0 & 0 & 0 & cerebelo \\
\hline 06-11381 & $\mathrm{F} / 70$ & 0 & 0 & 0 & cerebelo \\
\hline $07-02149$ & $\mathrm{~F} / 76$ & 0 & 0 & 0 & cerebelo \\
\hline $05-06334$ & $\mathrm{~F} / 77$ & 0 & 0 & 0 & cerebelo \\
\hline 08-07106 & $\mathrm{F} / 75$ & 0 & 0 & 0 & cerebelo \\
\hline
\end{tabular}




\begin{tabular}{llllll}
\hline $05-07178$ & $\mathrm{~F} / 75$ & 0 & 0 & 0 & cerebelo \\
$05-07213$ & $\mathrm{~F} / 74$ & 0 & 0 & 0 & cerebelo \\
$05-07759$ & $\mathrm{~F} / 75$ & 0 & 0 & 0 & cerebelo \\
$09-01982$ & $\mathrm{~F} / 73$ & 0 & 0 & 0 & cerebelo \\
$09-04181$ & $\mathrm{~F} / 77$ & 0 & 0 & 0 & cerebelo \\
$09-05121$ & $\mathrm{~F} / 77$ & 0 & 0 & 0 & cerebelo \\
$05-10921$ & $\mathrm{M} / 81$ & 0 & 0 & 0 & cerebelo \\
$05-02574$ & $\mathrm{M} / 83$ & 0 & 0 & 0 & cerebelo \\
$05-06677$ & $\mathrm{M} / 84$ & 0 & 0 & 0 & cerebelo \\
$06-07711$ & $\mathrm{M} / 85$ & 0 & 0 & 0 & cerebelo \\
$08-09173$ & $\mathrm{M} / 83$ & 0 & 0 & 0 & cerebelo \\
$09-09467$ & $\mathrm{M} / 82$ & 0 & 0 & 0 & cerebelo \\
$05-09766$ & $\mathrm{M} / 89$ & 0 & 0 & 0 & cerebelo \\
$05-05013$ & $\mathrm{~F} / 81$ & 0 & 0 & 0 & cerebelo \\
$08-06868$ & $\mathrm{~F} / 89$ & 0 & 0 & 0 & cerebelo \\
$05-07136$ & $\mathrm{~F} / 82$ & 0 & 0 & 0 & cerebelo \\
$08-01856$ & $\mathrm{~F} / 90$ & 0 & 0 & 0 & cerebelo \\
$09-04631$ & $\mathrm{~F} / 97$ & 0 & 0 & 0 & cerebelo \\
$09-01954$ & $\mathrm{~F} / 59$ & 0 & 0 & 0 & cerebelo \\
\hline
\end{tabular}

Braak = Estágios de Braak; CERAD = Consórcio para Estabelecer um Registro para a Doença de Alzheimer; $\mathrm{CDR}=$ Escala de Demência Clínica.

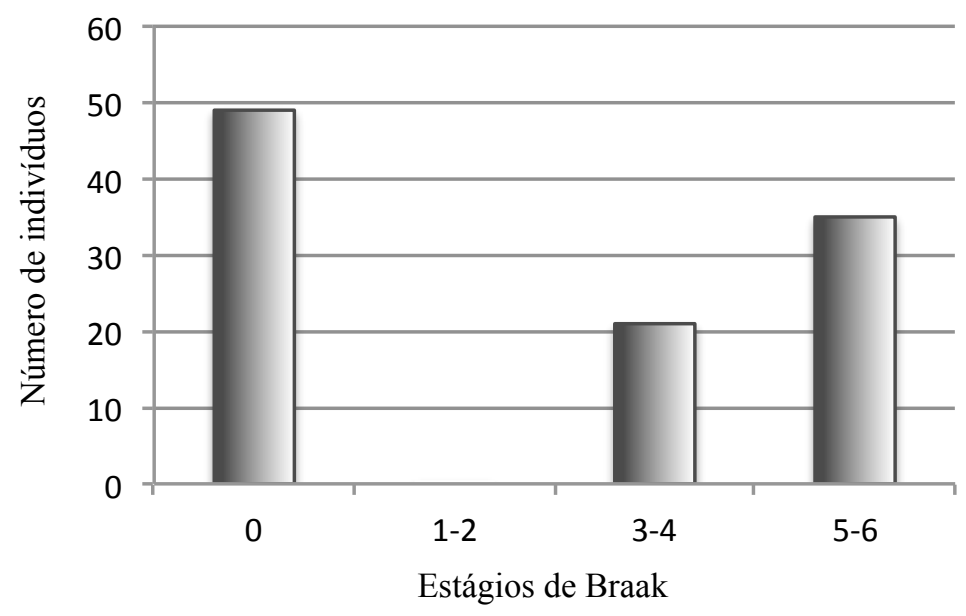

Figura 8. Distribuição da frequência das amostras controle e doença de Alzheimer (DA), usadas no estudo sobre a investigação de variações no número de cópias de segmentos de DNA (CNVs), de acordo com seus respectivos valores correspondentes aos estágios de Braak. As amostras com valor de Braak 0 equivalem a todos os sujeitos controle. Já as que apresentam valores 3-4 ou 5-6 correspondem aos indivíduos com DA. Estágios de Braak 1-2, 3-4 e 5-6 equivalem a um grau leve, moderado e profundo da DA, respectivamente. Note que a maioria das nossas amostras de DA apresentam um grau profundo da doença. 


\subsection{Parte II. Estudo do padrão de metilação do DNA na Doença de Alzheimer}

Para este estudo, utilizamos DNA extraído de amostras do córtex temporal de indivíduos com a forma multifatorial da DA. A extração do DNA dessas amostras de tecido cerebral foi feita por fenol-clorofórmio em nosso laboratório (vide seção Métodos).

\subsubsection{Critérios de seleção das amostras para este estudo:}

a) Grupo Doença de Alzheimer (DA): selecionamos 10 sujeitos que apresentassem dentro da escala dos critérios de Braak, CERAD e CDR, as alterações mais significativas em seus cérebros, ou seja, que representassem um quadro extremo de manifestação da forma multifatorial da DA. A Tabela 3 descreve em detalhes todos os casos, com informações sobre estágios de Braak, CERAD e CDR dessas amostras.

b) Grupo Controle: como respectivos controles, selecionamos 10 sujeitos, pareados por idade e sexo, sem histórico de demência e sem alterações neuropatológicas que preenchesse nenhum critério de qualquer doença neurodegenerativa (Tabela 4).

Tabela 3. Descrição de todos os casos do grupo Doença de Alzheimer para o estudo global do padrão de metilação do DNA.

\begin{tabular}{lcccc}
\hline Caso & Genêro/Idade & Braak & CERAD & CDR \\
\hline $09-06787$ & $\mathrm{~F} / 83$ & 6 & $\mathrm{C}$ & 3 \\
$08-07207$ & $\mathrm{~F} / 84$ & 6 & $\mathrm{C}$ & 3 \\
$08-02682$ & $\mathrm{M} / 82$ & 6 & $\mathrm{C}$ & 3 \\
$09-02544$ & $\mathrm{M} / 80$ & 5 & $\mathrm{C}$ & 3 \\
$09-02704$ & $\mathrm{~F} / 79$ & 6 & $\mathrm{C}$ & 3 \\
$07-05248$ & $\mathrm{~F} / 86$ & 5 & $\mathrm{C}$ & 3 \\
$09-08875$ & $\mathrm{~F} / 94$ & 6 & $\mathrm{C}$ & 3 \\
$07-01345$ & $\mathrm{~F} / 83$ & 6 & $\mathrm{C}$ & 3 \\
$07-01350$ & $\mathrm{~F} / 80$ & 5 & $\mathrm{C}$ & 3 \\
$05-11075$ & $\mathrm{~F} / 83$ & 6 & $\mathrm{C}$ & 3 \\
\hline
\end{tabular}

Braak = Estágios de Braak; CERAD = Consórcio para Estabelecer um Registro para a Doença de Alzheimer; $\mathrm{CDR}=$ Escala de Demência Clínica.

Tabela 4. Descrição de todos os casos do grupo controle para o estudo global do padrão de metilação do DNA.

\begin{tabular}{lcccc}
\hline Caso & Genêro/Idade & Braak & CERAD & CDR \\
\hline $09-04397$ & $\mathrm{~F} / 81$ & 0 & 0 & 0 \\
$06-07711$ & $\mathrm{M} / 85$ & 0 & 0 & 0 \\
\hline
\end{tabular}




\begin{tabular}{lcccc}
\hline $09-04631$ & $\mathrm{~F} / 97$ & 0 & 0 & 0 \\
$05-02574$ & $\mathrm{M} / 83$ & 0 & 0 & 0 \\
$08-09173$ & $\mathrm{M} / 83$ & 0 & 0 & 0 \\
$05-06715$ & $\mathrm{~F} / 81$ & 0 & 0 & 0 \\
$06-07711$ & $\mathrm{M} / 85$ & 0 & 0 & 0 \\
$05-02574$ & $\mathrm{M} / 83$ & 0 & 0 & 0 \\
$05-06334$ & $\mathrm{~F} / 77$ & 0 & 0 & 0 \\
$05-01961$ & $\mathrm{~F} / 81$ & 0 & 0 & 0 \\
\hline Braak = Estágios de Braak; CERAD = Consórcio para Estabelecer um Registro para a Doença de Alzheimer; CDR \\
= Escala de Demência Clínica.
\end{tabular}

\section{Métodos}

\subsection{Extração de DNA com fenol-clorofórmio}

Cerca de $25 \mathrm{mg}$ de cerebelo ou córtex temporal foram macerados com a ajuda de um pistilo em um tubo de ensaio pequeno com $500 \mu 1$ de PBS (137 mM NaCl, 2,7 mM KCl, 10 $\mathrm{mM} \mathrm{Na}_{2} \mathrm{HPO}_{4}, 1,8 \mathrm{mM} \mathrm{KH}_{2} \mathrm{PO}_{4}$ ). Em seguida, foram adicionados $30 \mu \mathrm{de}$ SDS $10 \%$ e $10 \mu 1$ de proteinase $\mathrm{K}(10 \mathrm{mg} / \mathrm{ml})$ e as amostras foram incubadas a $37{ }^{\circ} \mathrm{C}$ por cerca de $24 \mathrm{~h}$. Após o período de incubação, adicionou-se $400 \mu 1$ de fenol (Invitrogen, Califórnia, USA) às amostras seguida de uma centrifugação a $14.000 \mathrm{rpm}, 4{ }^{\circ} \mathrm{C}$, por $10 \mathrm{~min}$. O sobrenadante foi removido com pipeta e transferido para um novo tubo e $200 \mu 1$ de fenol e de clorofórmio-álcool isoamílico (24:1) (Invitrogen, Califórnia, USA) foram adicionados às amostras. Após uma nova centrifugação $\left(14.000 \mathrm{rpm}, 4{ }^{\circ} \mathrm{C}, 10 \mathrm{~min}\right)$ e retirada do sobrenadante, adicionou-se 400 $\mu 1$ de clorofórmio-álcool isoamílico (24:1) seguida de uma centrifugação na mesma velocidade e tempo. Posteriormente, o sobrenadante foi transferido para um novo tubo e $50 \mu 1$ de NaAc (3M) e $1 \mathrm{ml}$ de etanol gelado foram adicionados. Para terminar de precipitar o DNA, as amostras foram incubadas no congelador por $2 \mathrm{~h}$ e, após esse período, centrifugadas a $14.000 \mathrm{rpm}, 4{ }^{\circ} \mathrm{C}$, por $20 \mathrm{~min}$. O etanol foi removido e adicionou-se $500 \mu \mathrm{l}$ de etanol $70 \%$ gelado seguida de uma nova centrifugação. Por fim, removeu-se novamente o etanol até sua evaporação por completo, e o DNA foi ressuspendido em 50 ou $100 \mu 1$ de TE (10 mM Tris$\mathrm{HCl}$ pH 8,0, 1 mM EDTA) estéril. A quantificação do DNA foi realizada usando o espectofotômetro NanoDrop 2000 (Thermo Scientific, Massachusetts, USA).

\subsection{Investigação de desequilíbrios genômicos submicroscópicos por array-CGH}

Para a investigação de desequilíbrios genômicos submicroscópicos por array-CGH utilizamos oligoarrays produzidos comercialmente pela OGT (Oxford Gene Techonology, 
Oxford, UK). A plataforma escolhida foi a 4x180K que contém 4 áreas de aproximadamente 180.000 oligonucleotídeos com 60 pb cada. Os procedimentos de desnaturação, marcação, purificação, precipitação, hibridação e lavagem das amostras estão descritos a seguir.

\subsubsection{Desnaturação e Marcação do DNA genômico}

Para a marcação do DNA, utilizamos o kit CytoSure Genomic DNA Labelling (Oxford Gene Techonology, Oxford, UK). Foi utilizado 600 ng de DNA genômico, em volume final de $18 \mu \mathrm{L}$ da reação. O DNA foi desnaturado a $95{ }^{\circ} \mathrm{C}$ de 5 a $15 \mathrm{~min}$, sendo o menor tempo destinado às amostras mais fragmentadas. Em seguida, $10 \mu \mathrm{L}$ de Buffer $C(10 \%$ do volume final) e $10 \mu \mathrm{L}$ de Random Primers foram adicionadas em cada amostra, as quais permaneceram por mais $3 \mathrm{~min}$ a $95{ }^{\circ} \mathrm{C}$ e incubadas em gelo por $5 \mathrm{~min}$. Posteriormente, uma mistura contendo dCTP, Cy3-dCTP (para a amostra teste) ou Cy5-dCTP (para a amostra referência) e enzima Klenow foi adicionada em cada amostra. As amostras foram mantidas a $37^{\circ} \mathrm{C}$ por $2 \mathrm{~h}$, procedendo-se em seguida à inativação da enzima por $10 \mathrm{~min}$ a $65^{\circ} \mathrm{C}$.

\subsubsection{Purificação}

Após a marcação, as amostras foram purificadas utilizando-se o kit Illustra ProbeQuant G-50 Micro Colummns (GE Healthcare, Buckinghamshire, UK) de acordo com o protocolo do fabricante. A quantificação do DNA genômico marcado e da atividade específica dos fluorocromos Cy3-dCTP e Cy5-dCTP foi realizada no espectofotômetro NanoDrop 2000 (Thermo Scientific, Massachusetts, USA)

\subsubsection{Precipitação}

A $50 \mu \mathrm{L}$ do DNA teste (marcado com Cy3) e $50 \mu \mathrm{L}$ do DNA referência (marcado com Cy5) foram adicionados $5 \mu \mathrm{L}$ de Human DNA Cot-1 (Life Technologies, Califórnia, USA), para o volume final de $105 \mu \mathrm{L}$. Em seguida, foram adicionados $\mathrm{NaAc}(3 \mathrm{M}, \mathrm{pH} 5,0 ; 10 \%$ do volume final) e etanol $100 \%$ gelado (2,5X o volume final). As amostras foram precipitadas por $2 \mathrm{~h}$ a $-20^{\circ} \mathrm{C}$.

\subsubsection{Hibridação}

Após a etapa de precipitação, as amostras foram centrifugadas por 20 min a 14.000 rpm a $4{ }^{\circ} \mathrm{C}$. Em seguida, adicionou-se etanol 70\% gelado e procedeu-se a centrifugação por mais 5 min a $14.000 \mathrm{rpm}$, descartando-se o sobrenadante. Seguiu-se nova centrifugação por mais $1 \mathrm{~min}$, descartando-se também o sobrenadante. O DNA marcado foi então ressuspendido em TE previamente aquecido a $72{ }^{\circ} \mathrm{C}$. Posteriormente, foram adicionadas as soluções 
Blocking Solution 10X e Hybridization Buffer 2X, e procedeu-se a desnaturação por 3 min a $95^{\circ} \mathrm{C}$ e, em seguida, 30 min a $37^{\circ} \mathrm{C}$. Todo o volume das amostras foi adicionado à lâmina de suporte do microarray, e então a lâmina de microarray foi colocada sobre ela. As amostras foram hibridadas a $65^{\circ} \mathrm{C}$ por $16-48 \mathrm{~h}$.

\subsubsection{Lavagem}

A lâmina de microarray foi mergulhada em soluções tampão Buffer 1 por 8 min e Buffer 2 (previamente aquecido a $37^{\circ} \mathrm{C}$ ) por $1 \mathrm{~min}$, seguido de $10 \mathrm{~s}$ em Acetonitrila e $30 \mathrm{~s} \mathrm{em}$ Stabilization Drying Solution (todos os produtos Agilent Technologies, Califórnia, USA).

As imagens do array obtidas com o uso do DNA Microarray Scanner (Agilent Technologies, Califórnia, USA) foram processadas e analisadas, utilizando o pacote de programas Feature Extraction v9.5.1 e CGH Analytics 3.4 .40 (ambos da Agilent Technologies, Califórnia, USA), usando o algoritmo estatístico ADM-2 e limiar de sensibilidade 6.0. Para a avaliação de ganhos ou perdas no número de cópias de segmentos de DNA, apenas as alterações que continham no mínimo três oligonucleotídeos consecutivos com o $\log _{2}$ da razão teste/referência $\geq 0,3$ ou $\leq-0.3$, foram consideradas pelo programa como possíveis CNVs. Usando uma plataforma $180 \mathrm{~K}$, a precisão de mapeamento das alterações é de aproximadamente $17 \mathrm{~Kb}$, que é o espaçamento médio entre os oligonucleotídeos, embora as regiões gênicas tenham um espaçamento médio menor que as regiões intragênicas. Em todas as hibridações, nossas amostras foram pareadas por sexo com DNA de um pool de indivíduos selecionados como controle em nosso laboratório. As CNVs identificadas em nossa casuística foram comparadas às variações documentadas no Database of Genomic Variants (DGV, http://dgvbeta.tcag.ca/dgv/app/home), banco de dados responsável por catalogar as CNVs presentes em indivíduos controle, e no DECIPHER (http://decipher.sanger.ac.uk), banco de dados que documenta desequilíbrios genômicos identificados em indivíduos afetados por diferentes patologias congênitas. Com base nas frequências apresentadas no DGV, as CNVs foram classificadas em "comuns" e raras, sendo as raras definidas como aquelas com frequência $<0,1 \%$. Além disso, para excluir a possibilidade de que essas CNVs raras representassem variantes comuns na população brasileira, nós compilamos dados sobre CNVs de mais de 400 amostras estudadas em nosso laboratório, usando a mesma plataforma de array-CGH 180K, e nenhuma das CNVs raras documentadas nesse estudo haviam sido identificadas nessas amostras. É importante ressaltar que essas mais de 400 amostras, arquivadas em nosso banco de dados, foram investigadas por razões diferentes de demência. 


\subsection{Ensaio de metilação do DNA}

O ensaio de metilação foi feito como prestação de serviço pela empresa de biotecnologia Deoxi (http://www.deoxi.com.br). Em resumo, 600 ng de cada amostra de DNA foram tratadas com bissulfito de sódio utilizando o kit de conversão específico da Illumina de acordo com as recomendações do fabricante (EZ DNA Methylation Kit, Zymo Research). Após o tratamento, as citosinas não metiladas são convertidas em uracilas enquanto que as citosinas metiladas permanecem como citosinas. $4 \mu 1$ de DNA tratado com bissulfito foram usados para hibridação na plataforma 450K da Illumina - Infinium Human Methylation 450K BeadChips (Illumina, Califórnia, USA), seguindo o protocolo Illumina Infinium HD Methylation. Abreviadamente, o ensaio consiste de uma etapa de amplificação do genoma todo seguida por uma fragmentação enzimática, precipitação e ressuspensão do DNA. As amostras ressuspendidas foram hibridizadas na 450k BeadChips a $48^{\circ} \mathrm{C}$ por $16 \mathrm{~h}$. Após uma etapa de lavagem, o DNA tratado com bissulfito que foi hibridizado é utilizado como molde para uma extensão de bases-única. Os nucleotídeos incorporados foram marcados com biotina (ddCTP e ddGTP) e 2,4-dinitrofenol (DNP) (ddATP e ddTTP). Após a extensão de bases, várias séries de marcação foram feitas com uma combinação de anticorpos e, biotina e DNP diferenciados foram fixados com diferentes fluoróforos. Em seguida, a BeadChip foi lavada e protegida para ser escaneada.

\subsubsection{Escaneamento e processamento dos dados}

As amostras foram escaneadas pelo Illumina HiScan $S Q$, um escâner de fluorescência com laser de duas cores e resolução espacial de $0.375 \mu \mathrm{m}$, capaz de excitar os fluoróforos incorporados durante a etapa de marcação do protocolo. As intensidades das imagens do array foram extraídas pelo programa computacional GenomeStudio da Illumina (v. 2010.3) usando o módulo Metilação (v. 1.8.5). O escore de metilação para cada $\mathrm{CpG}$ é representado por um valor de Beta, calculado de acordo com as razões das intensidades de fluorescência das sondas metiladas em relação ao total das sondas $(\beta=\operatorname{Max}(\operatorname{SignalB}, 0) /(\operatorname{Max}(\operatorname{SignalA}, 0)+$ Max $($ SignalB,0) +100). Valores de Beta variam entre 0 (não metilado) e 1 (completamente metilado). Os dados foram normalizados usando os métodos Normalization to Internal Controls e Background Subtraction oferecidos pelo GenomeStudio. Antes de prosseguir com nossa análise, excluímos as sondas correspondentes aos cromossomos X e Y para evitar um possível viés de metilação específico ao sexo, uma vez que é sabido que o cromossomo $\mathrm{X}$ apresenta uma metilação diferencial entre homens e mulheres e o Y está presente só no homens. Além disso, eliminamos também as sondas com baixa qualidade, ou seja, com um p 
valor de detecção >0.01. Logo, das 485.577 sondas presentes na plataforma 450K da Illumina, reduzimos a quantidade de $\mathrm{CpG}$ que seriam avaliados para 471.994.

Em seguida, fizemos uma análise de metilação diferencial a partir do teste U de MannWhitney com Cálculo de Falsa Descoberta (Compute False Discovery Rate) (GenomeStudio). Valores de Delta Beta indicando uma metilação diferencial entre os $\mathrm{CpG}$ das amostras controle e teste foram calculados subtraindo os valores da média do valor de Beta do pool das amostras teste versus o pool das amostras controle. Consideramos como CpG diferencialmente metilados aqueles com uma diferença $\geq 20 \%$ no valor de Delta Beta (valor maior que 0,2 ou menor que $-0,2$ ), pois este representa o mínimo de diferença do score de metilação entre duas amostras passível de ser validado por pirosequenciamento. Recentemente, Price e colaboradores publicaram um manuscrito demonstrando que a plataforma $450 \mathrm{~K}$ da Illumina apresenta $4.3 \%$ de sondas associadas a SNPs e $8.6 \%$ de sondas inespecíficas, que se anelam em múltiplos locais no genoma. Os autores igualmente anotaram o número de pares de base no caso de uma sonda se parear em sequências repetitivas (Price et al., 2013). Levando em consideração essas informações, adotamos como critério em nosso estudo excluir as sondas inespecíficas, que não estão associadas a genes ou que se anelam em um número de pares de base maior que 20 em sequência repetitiva. A Figura 9 mostra um fluxograma com todas as etapas da análise de metilação realizadas em nosso projeto. 
Processamento dos dados

Normalização dos dados:

- Normalization to Internal Controls

- Background Subtraction

Quantificação do nível de metilação de cada $\mathrm{CpG}$

(valor de Beta)

Exclusão das sondas que correspondem aos cromossomos

$\mathrm{X}$ e $\mathrm{Y}$ e aquelas com p-valor de detecção $>0.01$

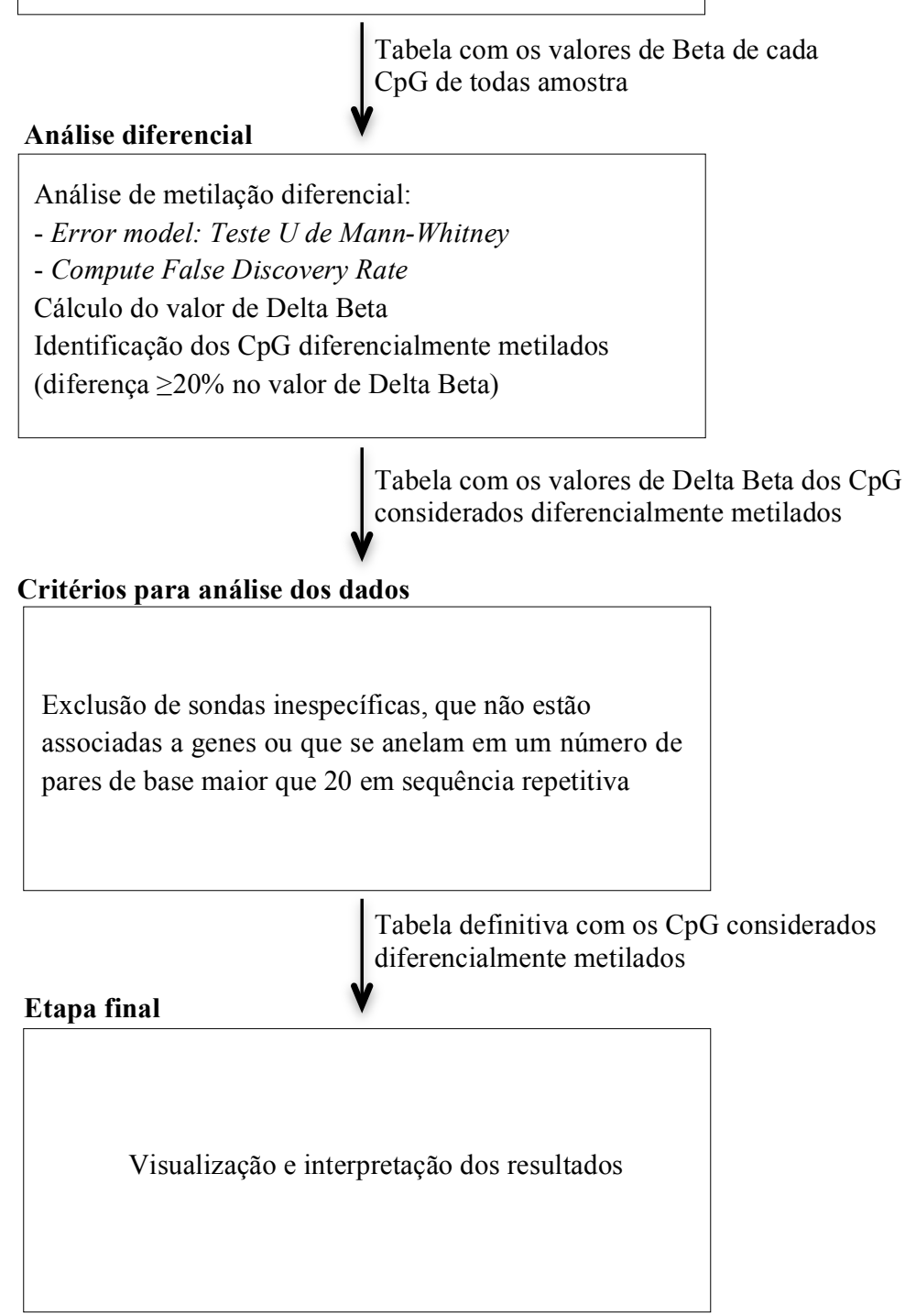

Figura 9. Fluxograma com todas as etapas realizadas na análise do padrão de metilação do DNA em nosso estudo. 


\section{RESULTADOS}




\section{RESULTADOS}

1. Parte I. Estudo sobre a investigação de variações no número de cópias de segmentos de DNA (CNV) na doença de Alzheimer (DA)

A Tabela 5 apresenta um resumo dos resultados das análises de array-CGH nos grupos controle e DA. Ao todo, foram detectadas 960 CNVs em 95 indivíduos. Porém, de acordo com a análise estatística, o grupo controle apresenta um aumento significativo no número total de CNVs por indivíduo se comparado ao grupo DA $(P<0,05$; teste $\mathrm{U}$ de MannWhitney). Além disso, com base no DGV, 95\% das CNVs observadas nos nossos dois grupos de estudo correspondem a variantes comuns na população. Logo, somente 42 (5\%), das 960 CNVs detectadas, foram classificadas como raras, sendo que nenhuma delas apresenta-se como recorrente em nossa casuística.

Enquanto no grupo controle, as CNVs raras correspondem a 3,43\% (19 de 554) e foram detectadas em 12 dos 49 indivíduos, no grupo DA, as CNVs raras equivalem a 5,66\% (23 de 406) e foram encontradas em 14 dos 46 indivíduos. Porém, nem a diferença da proporção nem a média de CNVs raras por indivíduo foi significante entre os dois grupos $(P=$ 0,4901; teste U de Mann-Whitney). Investigamos também as CNVs raras acerca de tamanho e densidade gênica (Tabela 6). Com relação ao tamanho, embora exista uma tendência das CNVs raras serem maiores no grupo controle, essa diferença não foi considerada estatisticamente significante ( $P=0,0728$; teste $\mathrm{U}$ de Mann-Whitney). No entanto, ao analisar separadamente o tamanho das deleções e duplicações em ambos os grupos, é possível observar que existe uma diferença no tamanho somente das deleções, sendo estas maiores no grupo controle ( $P<0,05$; teste $\mathrm{U}$ de Mann-Whitney). Já no que se refere a densidade gênica, não detectamos nenhuma diferença estatisticamente significante entre os dois grupos $(P=$ 0,2003; teste U de Mann-Whitney).

Tabela 5. Resumo da distribuição de todas as CNVs encontradas nos grupos controle e Doença de Alzheimer.

\begin{tabular}{lcc}
\hline CNVs & Controle $(\mathrm{n}=49)$ & Doença de Alzheimer $(\mathrm{n}=46)$ \\
\hline Total de CNVs $\dagger$ & $554 \dagger$ & 406 \\
Mediana de CNVs totais por indivíduo $\dagger$ & $11(3 \mathrm{a} 22) \dagger$ & $8.5(1$ a 21) \\
Variantes raras & 19 & 23 \\
Deleções & 13 & 10 \\
Duplicações & 6 & 13 \\
Média das CNVs raras por indivíduo & 0,39 & 0,5 \\
\hline CNVs $=$ variações no número de cópias de segmentos de DNA $\dagger P<0,05 ;$ teste Ude Mann-Whitney.
\end{tabular}

$\overline{\mathrm{CNVs}}=$ variações no número de cópias de segmentos de DNA. $\dagger P<0,05$; teste U de Mann-Whitney. 
Tabela 6. Tamanho e densidade gênica das CNVs raras encontradas nos grupos controle e Doença de Alzheimer.

\begin{tabular}{lcc}
\hline CNVs raras & Controle $(\mathrm{n}=19)$ & $\begin{array}{c}\text { Doença de Alzheimer } \\
(\mathrm{n}=23)\end{array}$ \\
\hline Gama de comprimento $(\mathrm{Kb})$ & 3 a 1.889 & 3 a 665 \\
Tamanho das CNVs raras $(\mathrm{Kb})$ & $385,186 \pm 11,3841 / n=19$ & $173,249 \pm 39,577 / n=23$ \\
Deleções $(\mathrm{Kb}) \dagger$ & $247,236 \pm 61,542 / n=13 \dagger$ & $71,807 \pm 15,055 / n=10$ \\
Duplicações $(\mathrm{Kb})$ & $684,078 \pm 31,9271 / n=6$ & $251,281 \pm 61,504 / n=13$ \\
Densidade gênica das CNVs raras $(\mathrm{Kb})$ & $27,76 \pm 13,09 / n=19$ & $50,09 \pm 18,31 / n=23$ \\
\hline $\mathrm{CNVs}=$ variações no número de cópias de segmentos de DNA. Densidade gênica $=\left(\mathrm{N}^{\circ}\right.$ de genes presentes na \\
CNV/Tamanho da CNV) x 1.000.000. $\dagger P<0,05 ;$ teste U de Mann-Whitney. Os valores estão apresentados como média \pm \\
SEM.
\end{tabular}

A descrição de todas as CNVs raras encontradas nos indivíduos do grupo controle e DA estão apresentadas nas Tabelas 7 e 8, respectivamente. Embora no grupo controle não tenhamos encontrado nenhuma CNV rara com conteúdo gênico relevante para envelhecimento cognitivo, no grupo DA destacamos 6 desequilíbrios genômicos raros especialmente interessantes para o fenótipo investigado. Os genes, compreendidos por essas CNVs, considerados pertinentes para a nossa casuística estão evidenciados em negrito na Tabela 8.

Apesar de dito anteriormente que nenhuma CNV rara, encontrada no grupo DA, apresenta-se como recorrente em nosso grupo de estudo, é importante ressaltar que dois indivíduos distintos de nossa casuística apresentam microduplicações em genes que codificam diferentes subunidades do mesmo tipo de canal de $\mathrm{Ca}^{2+}$ dependente de voltagem, o tipo $\mathrm{L}$ (CCDV-L). No caso do sujeito 09-06787, a microduplicação de aproximadamente $665 \mathrm{~Kb}$ ocorre em 3p21.1 e abrange 2 genes importantes para a formação dos CCDV-L (CACNA1D e $C A C N A 2 D 3$ ) (Figura 10). CACNA1D codifica a subunidade $\alpha_{1 \mathrm{D}}$, que atua como o poro condutor do íon dos CCDV-L e CACNA2D3 é responsável por codificar a subunidade $\alpha-2 \delta$, que regula a ativação e inativação do canal. A outra microduplicação de aproximadamente $300 \mathrm{~Kb}$, presente em 3p21.31, no indivíduo 05-06917, compreende o gene CACNA2D2 que age por similaridade ao $C A C N A 2 D 3$, ou seja, também é responsável por codificar a subunidade $\alpha-2 \delta$ (Figura 11). Além disso, dentre os outros genes selecionados como relevantes para o fenótipo investigado, 4 estão envolvidos em diferentes processos inflamatórios. PRKCQ, NFAM1, IL17RB, presentes em 10p15.1-p14, 22q13.2, 3p21.1, respectivamente, encontram-se duplicados em nossa casuística (Figuras 12, 13 e 14); já o gene $C R A D D$ está rompido por uma deleção em 12q22 (Figura 15). É importante ressaltar que a microduplicação em 3 p21.1 que comprrende o gene $I L 17 R B$ é a mesma CNV presente no indivíduo 09-06787 que também abrange os genes CACNA1D e CACNA2D3. O último 
gene que também foi considerado especialmente interessante em nosso grupo de estudo é o NAMPT, responsável por codificar a enzima nicotinamida fosforibosiltransferase (NAMPT), participante importante da via de biossíntese da molécula nicotinamida adenina dinucleotídeo (NAD). O gene em questão apresenta-se rompido por uma deleção de aproximadamente 145 $\mathrm{Kb}$ em 7q22.2, presente no indivíduo 06-11388 (Figura 16). A razão de $\log _{2}$ de todas as CNVs raras apresentadas neste estudo não sugere a presença de mosaicismo, indicando que esses desequilíbrios genômicos provavelmente são constitutivos.

Utilizando a ferramenta Variant Effect Predictor (VEP) disponível no site Ensembl (http://www.ensembl.org/info/docs/tools/vep/index.html) estimamos todas as possíveis consequências do conjunto de variações raras do grupo DA apresentado na Tabela 8, sendo que a maioria delas (34\%) equivale a amplificação do transcrito (Figura 17A). A mesma figura também apresenta uma subdivisão com as consequências pertencentes a categoria codificadora e mostra que $91 \%$ correspondem a variantes na sequência codificadora do DNA (Figura 17B). A Tabela 9 apresenta em detalhes somente as diversas consequências das CNVs dos genes que foram considerados relevantes para o fenótipo investigado. Investigamos também se os genes alterados pelos desequilíbrios genômicos raros encontrados no grupo DA, sejam eles considerados relevantes ou não para o fenótipo investigado, pertenciam a uma rede em comum. Através da análise feita pelo programa computacional Ingenuity Pathway Analysis, o qual permite correlacionar os genes de interesse com suas respectivas redes de interação molecular, identificamos uma rede que foi gerada algoritmicamente baseando-se na conectividade de genes. A rede identificada está relacionada com bioquímica de moléculas pequenas, interação e sinalização célula-célula e função e desenvolvimento do sistema hematológico, funções que não consideramos relevante para o fenótipo investigado (Figura 18A e B). O mesmo programa também ranqueou as cinco funções mais significantes dos genes em relação à diferentes categorias de funções biológicas (Figura 19). 


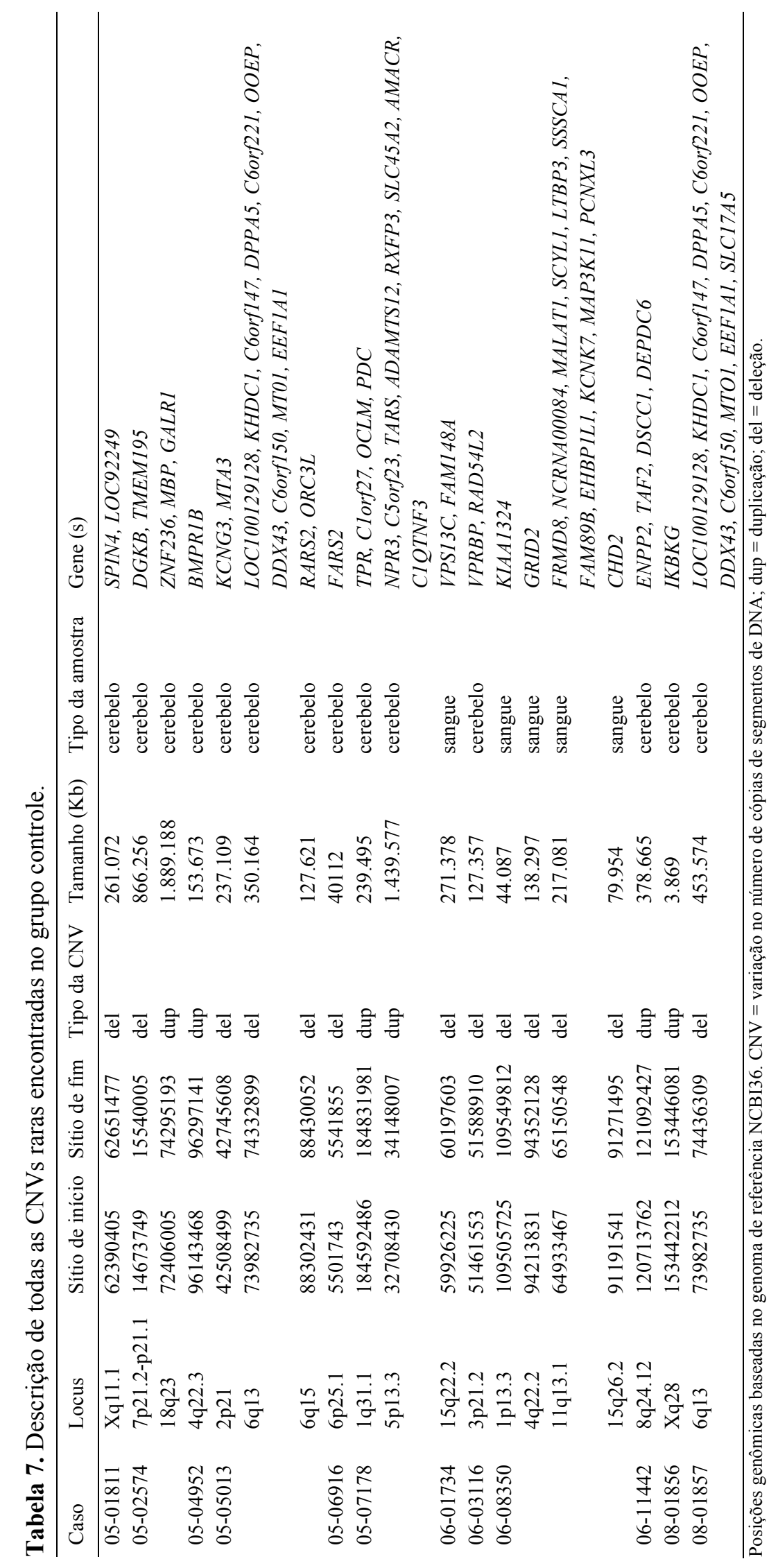




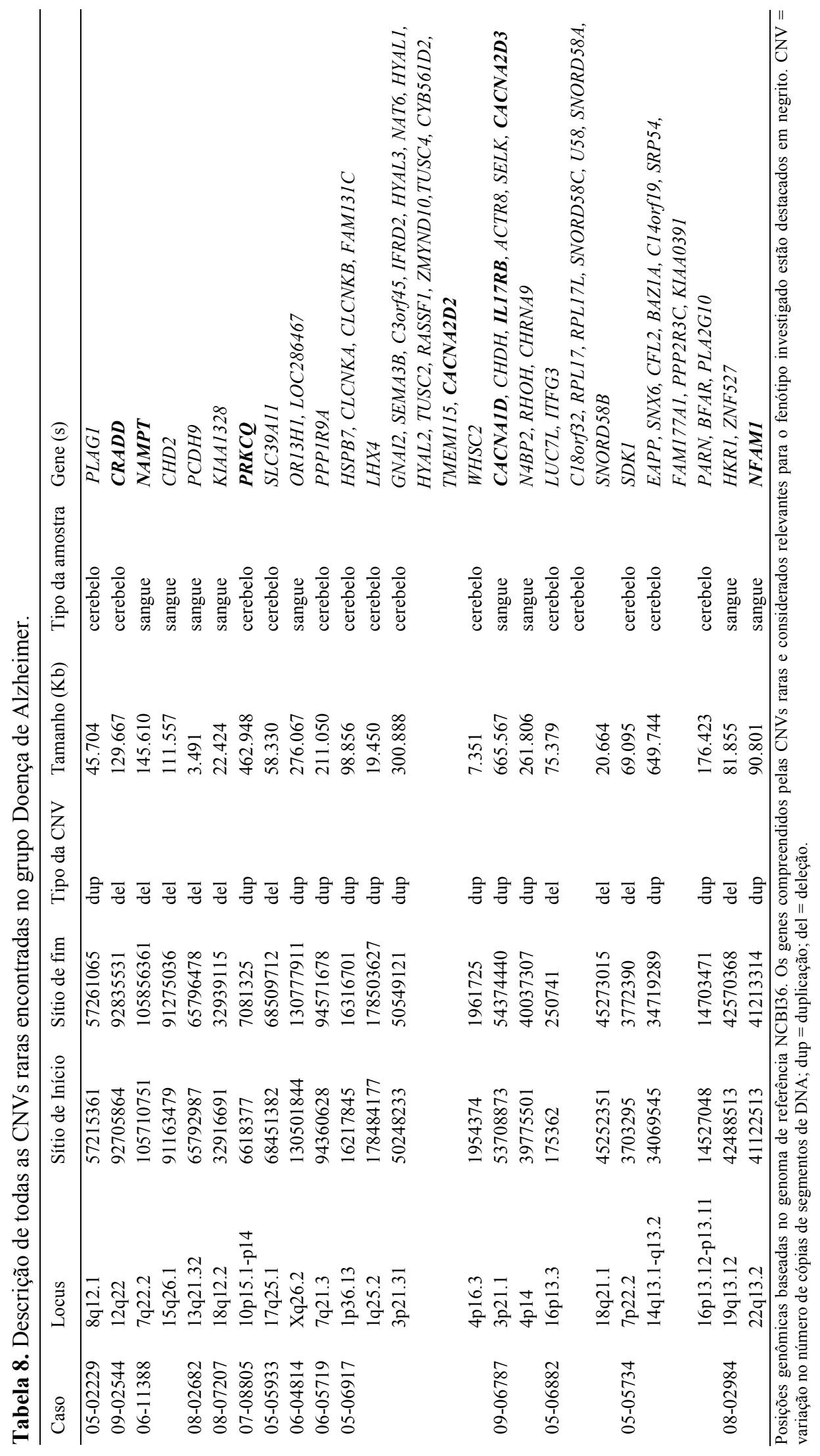


(A)

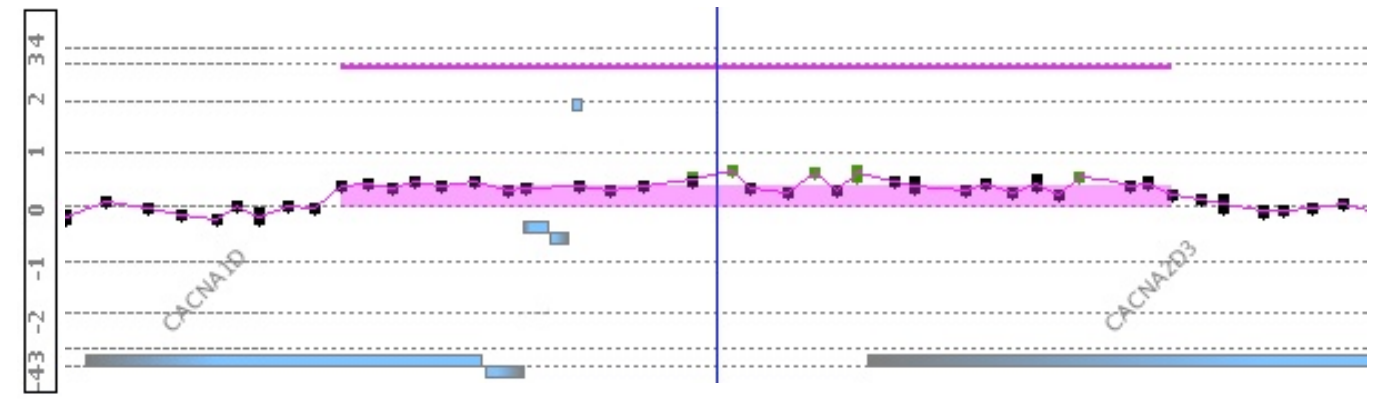

(B)

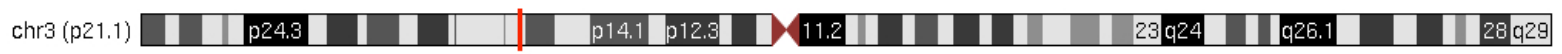

(C)

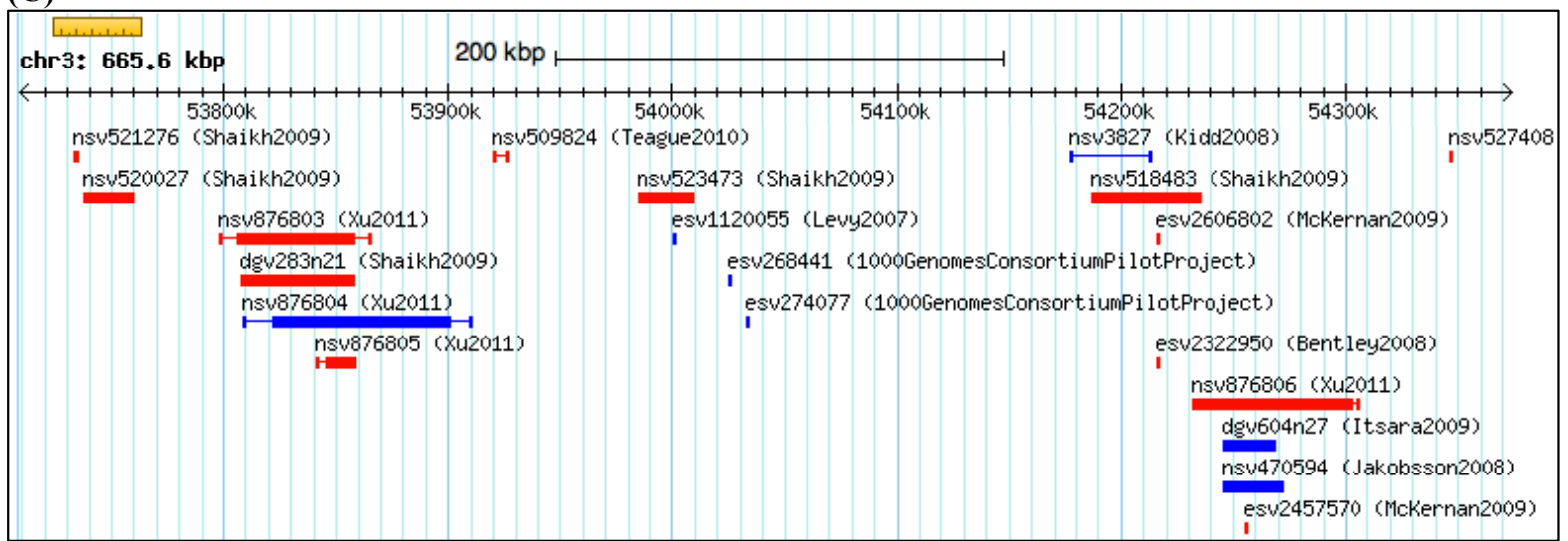

Figura 10. Microduplicação de $\sim 665 \mathrm{~Kb}$ em 3p21.1 presente no indivíduo 09-06787. (A) Perfil de arrayCGH mostrando em detalhes uma microduplicação no número de cópias de um segmento de DNA em 3p21.1 que abrange, dentre outros genes, dois, considerados especialmente relevantes para o fenótipo investigado: $C A C N A 1 D$ e CACNA2D3 (imagem extraída do programa computacional Genomic Workbench). (B) Ideograma do cromossomo 3 exibindo a posição exata dessa CNV, representada por uma pequena linha vermelha vertical no ideograma, e seu segmento genômico correspondente. (C) Região compreendida pela CNV mostrando os desequilíbrios genômicos que foram reportados na população geral pelo banco de dados Database of Genomic Variants (DGV). As barras vermelhas e azuis indicam ganho e perda de material genético, respectivamente (imagem extraída do DGV em janeiro de 2014). 
(A)

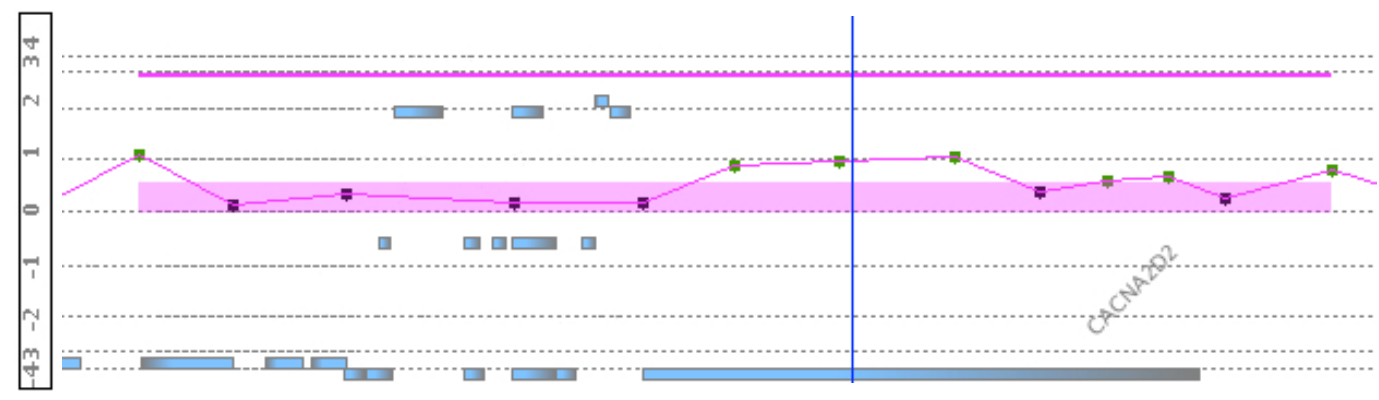

(B)

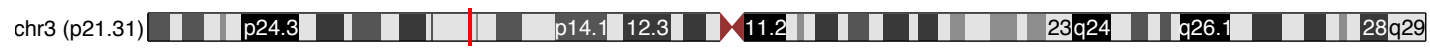

(C)

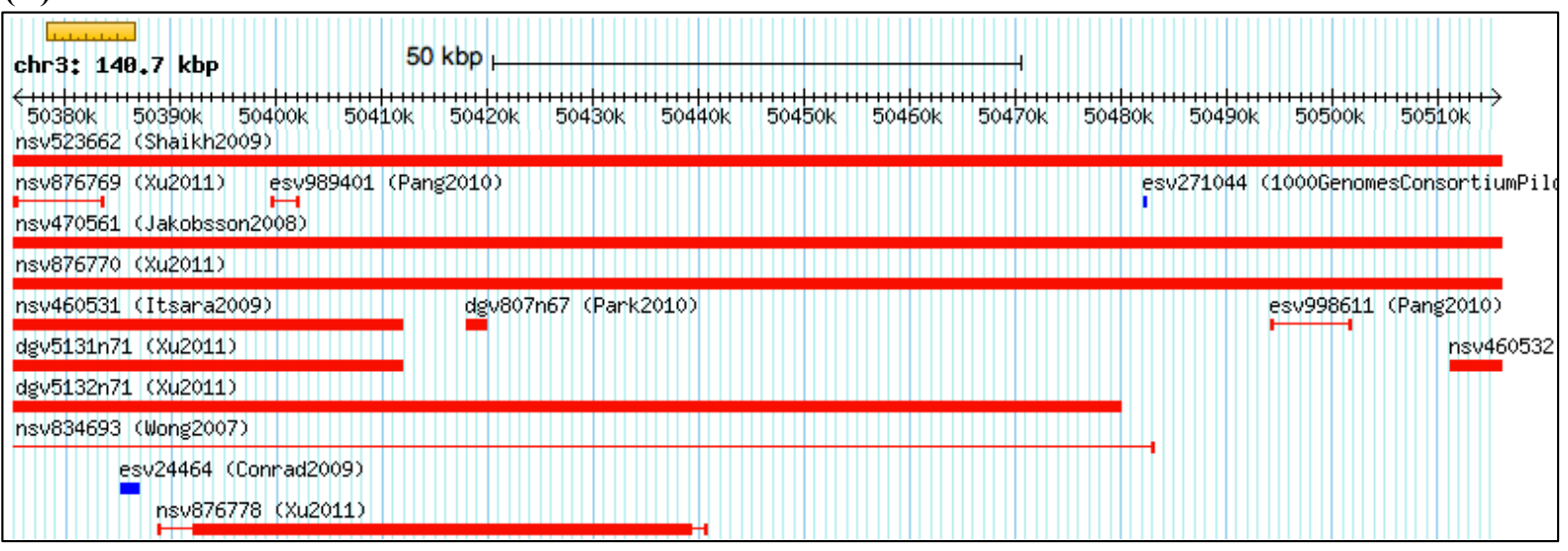

Figura 11. Microduplicação de $\sim 300$ Kb em 3p21.31 presente no indivíduo 05-06917. (A) Perfil de arrayCGH mostrando em detalhes uma microduplicação no número de cópias de um segmento de DNA em 3p21.31 que abrange, dentre outros genes, um considerado especialmente relevante para o fenótipo investigado: CACNA2D2 (imagem extraída do programa computacional Genomic Workbench). (B) Ideograma do cromossomo 3 exibindo a posição exata dessa $\mathrm{CNV}$, representada por uma pequena linha vermelha vertical no ideograma, e seu segmento genômico correspondente. (C) Região compreendida pela CNV mostrando os desequilíbrios genômicos que foram reportados na população geral pelo banco de dados Database of Genomic Variants (DGV). As barras vermelhas e azuis indicam ganho e perda de material genético, respectivamente (imagem extraída do DGV em janeiro de 2014). 
(A)

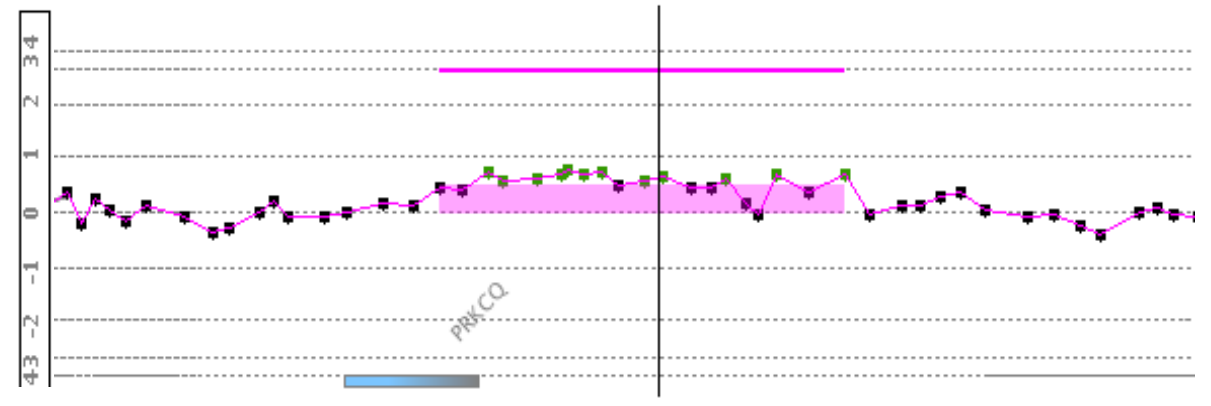

(B)

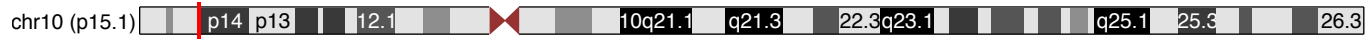

(C)

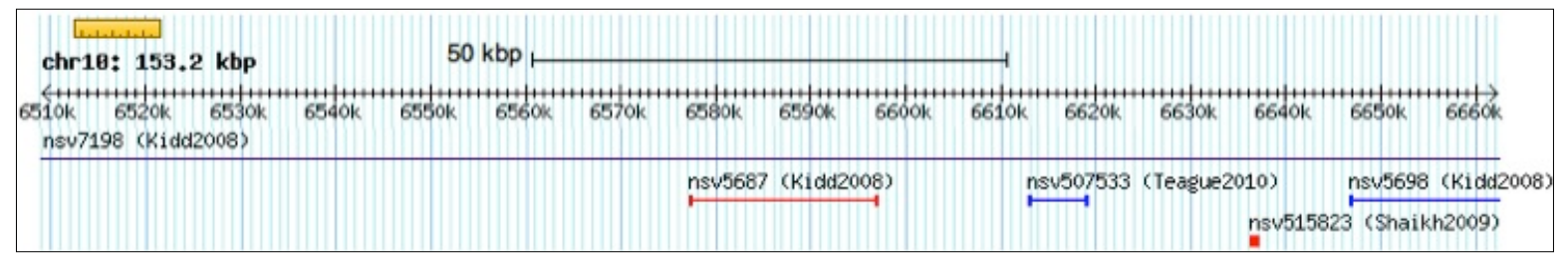

Figura 12. Microduplicação de $\sim 462 \mathrm{~Kb}$ em 10p15.1-p14 presente no indivíduo 07-08805. (A) Perfil de array-CGH mostrando em detalhes uma microduplicação no número de cópias de um segmento de DNA em 10p15.1-p14 que abrange o gene $P R K C Q$, considerado especialmente relevante para o fenótipo investigado (imagem extraída do programa computacional Genomic Workbench). (B) Ideograma do cromossomo 3 exibindo a posição exata dessa CNV, representada por uma pequena linha vermelha vertical no ideograma, e seu segmento genômico correspondente. (C) Região compreendida pela $\mathrm{CNV}$ mostrando os desequilíbrios genômicos que foram reportados na população geral pelo banco de dados Database of Genomic Variants (DGV). As barras vermelhas e azuis indicam ganho e perda de material genético, respectivamente; já a barra roxa indica a presença de inversão nessa região (imagem extraída do DGV em janeiro de 2014). 
(A)

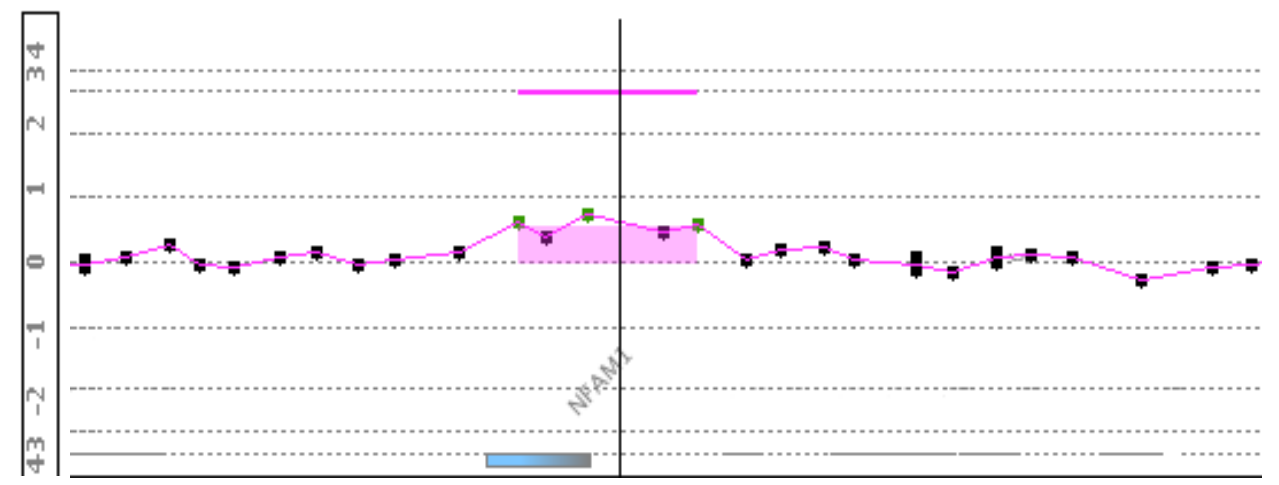

(B)

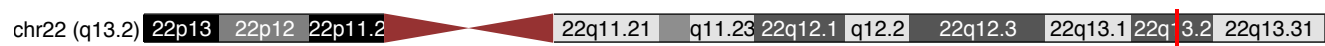

(C)

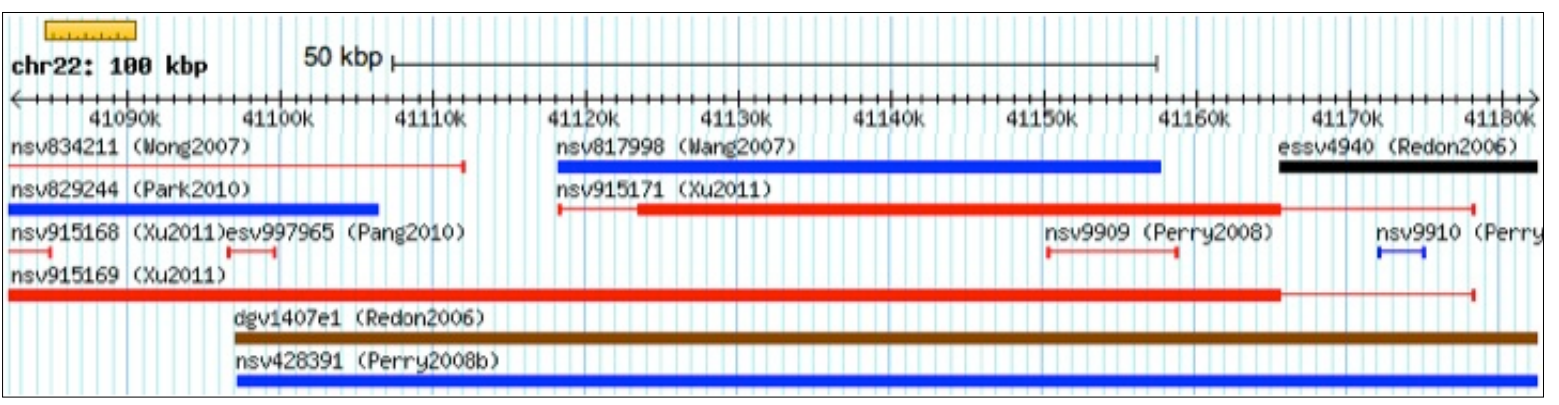

Figura 13. Microduplicação de $\sim 90 \mathrm{~Kb}$ em 22q13.2 presente no indivíduo 08-02984. (A) Perfil de arrayCGH mostrando em detalhes uma microduplicação no número de cópias de um segmento de DNA em 22q13.2 que abrange o gene $N F A M 1$, considerado especialmente relevante para o fenótipo investigado (imagem extraída do programa computacional Genomic Workbench). (B) Ideograma do cromossomo 22 exibindo a posição exata dessa CNV, representada por uma pequena linha vermelha vertical no ideograma, e seu segmento genômico correspondente. (C) Região compreendida pela $\mathrm{CNV}$ mostrando os desequilíbrios genômicos que foram reportados na população geral pelo banco de dados Database of Genomic Variants (DGV). As barras vermelhas e azuis indicam ganho e perda de material genético, respectivamente; já a barra marrom indica a presença de rearranjo complexo e a preta de CNV desconhecida (imagem extraída do DGV em janeiro de 2014). 
(A)

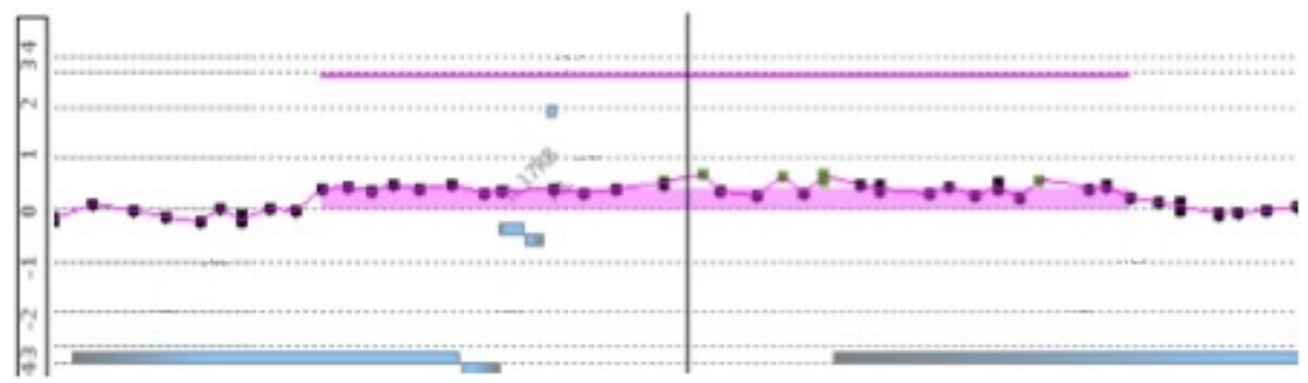

(B)

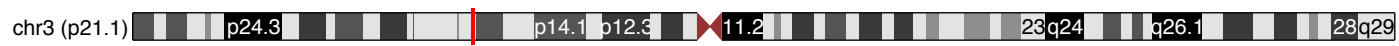

(C)

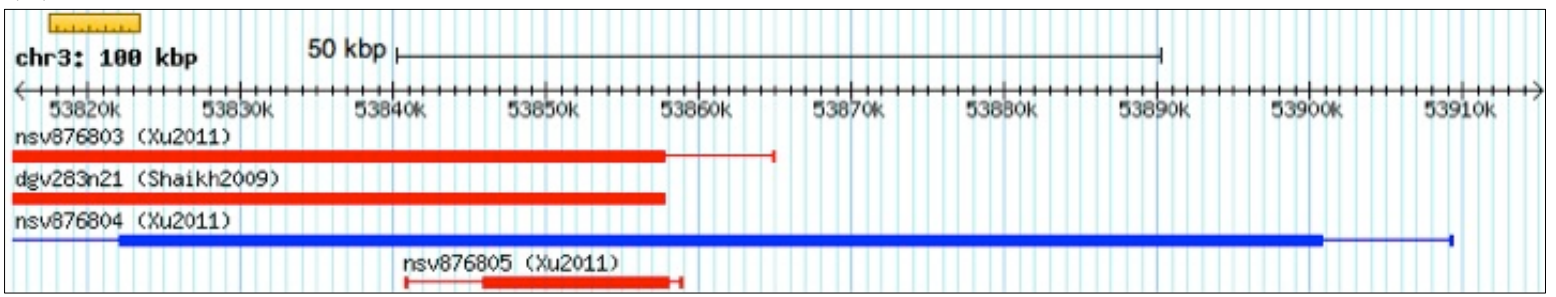

Figura 14. Microduplicação de $\sim 665 \mathrm{~Kb}$ em 3p21.1 presente no indivíduo 09-06787. (A) Perfil de arrayCGH mostrando em detalhes uma microduplicação no número de cópias de um segmento de DNA em 3p21.1 que abrange, dentre outros genes, um, considerado especialmente relevante para o fenótipo investigado: IL17RB (imagem extraída do programa computacional Genomic Workbench). (B) Ideograma do cromossomo 3 exibindo a posição exata dessa CNV, representada por uma pequena linha vermelha vertical no ideograma, e seu segmento genômico correspondente. (C) Região compreendida pela CNV mostrando os desequilíbrios genômicos que foram reportados na população geral pelo banco de dados Database of Genomic Variants (DGV). As barras vermelhas e azuis indicam ganho e perda de material genético, respectivamente (imagem extraída do DGV em janeiro de 2014). 
(A)

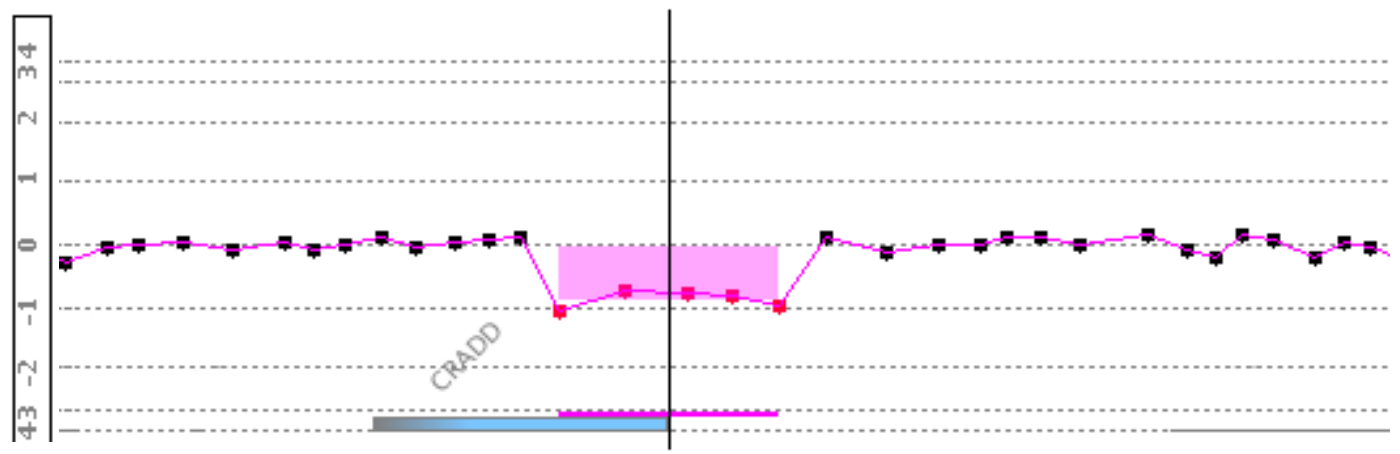

(B)

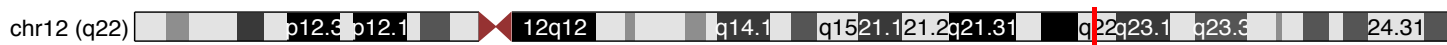

(C)

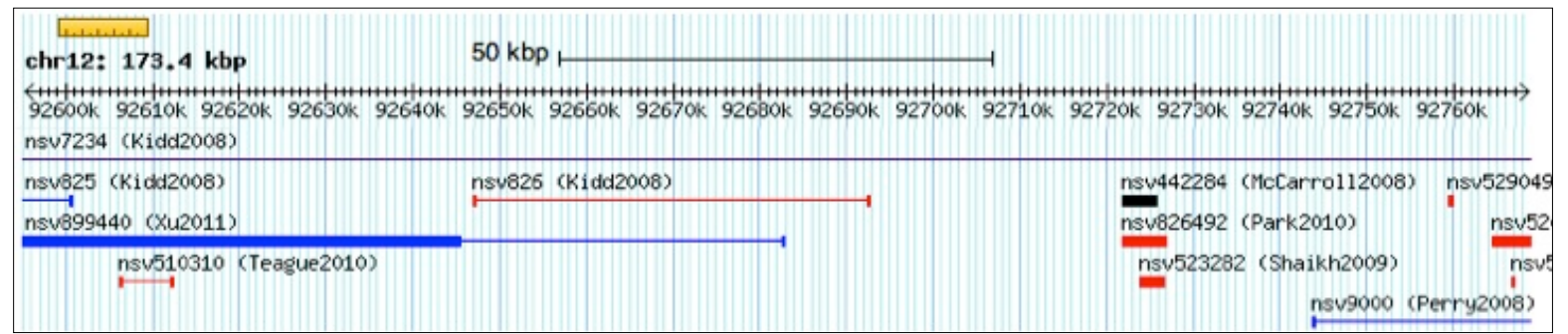

Figura 15. Microdeleção de $\sim 129$ Kb em 12q22 presente no indivíduo 09-02544. (A) Perfil de array-CGH mostrando em detalhes uma microdeleção no número de cópias de um segmento de DNA em 12q22 que abrange o gene $C R A D D$, considerado especialmente relevante para o fenótipo investigado (imagem extraída do programa computacional Genomic Workbench). (B) Ideograma do cromossomo 12 exibindo a posição exata dessa CNV, representada por uma pequena linha vermelha vertical no ideograma, e seu segmento genômico correspondente. (C) Região compreendida pela $\mathrm{CNV}$ mostrando os desequilíbrios genômicos que foram reportados na população geral pelo banco de dados Database of Genomic Variants (DGV). As barras vermelhas e azuis indicam ganho e perda de material genético, respectivamente; já a barra roxa indica a presença de inversão nessa região e a preta de CNV desconhecida (imagem extraída do DGV em janeiro de 2014). 
(A)

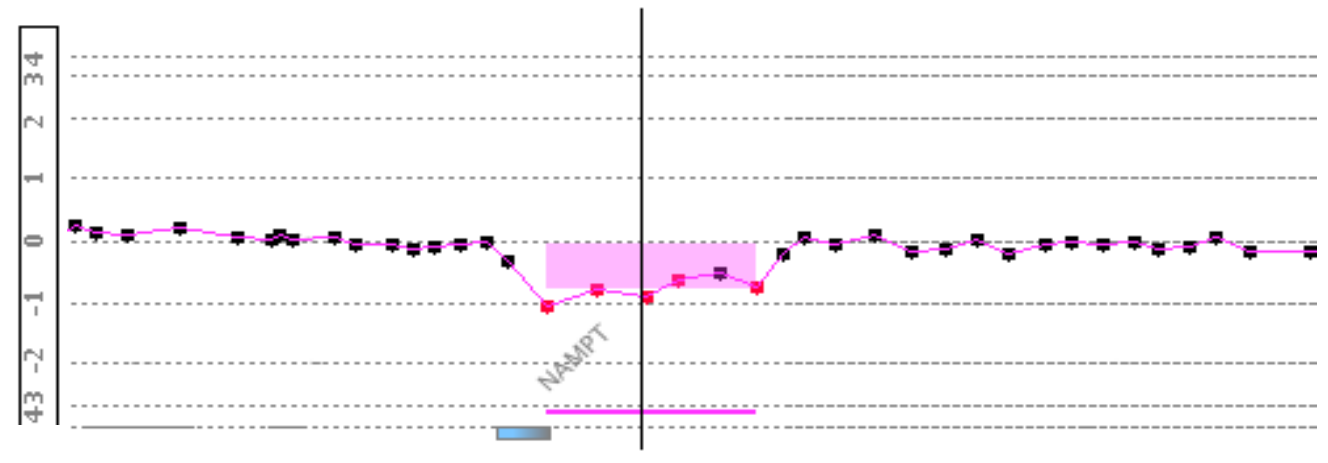

(B)

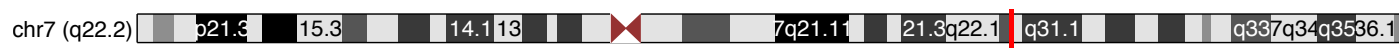

(C)

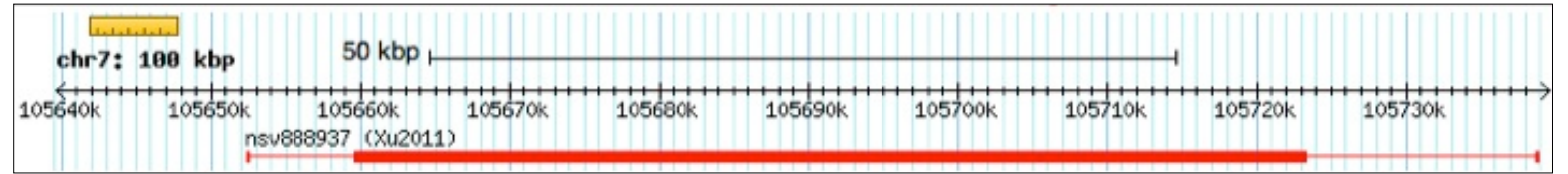

Figura 16. Microdeleção de $\sim \mathbf{1 4 5} \mathrm{Kb}$ em 7q22.2 presente no indivíduo 06-11388. (A) Perfil de array-CGH mostrando em detalhes uma microdeleção no número de cópias de um segmento de DNA em 7q22.2 que abrange o gene $N A M P T$, considerado especialmente relevante para o fenótipo investigado (imagem extraída do programa computacional Genomic Workbench). (B) Ideograma do cromossomo 7 exibindo a posição exata dessa $\mathrm{CNV}$, representada por uma pequena linha vermelha vertical no ideograma, e seu segmento genômico correspondente. (C) Região compreendida pela $\mathrm{CNV}$ mostrando os desequilíbrios genômicos que foram reportados na população geral pelo banco de dados Database of Genomic Variants (DGV). A barra vermelha indica ganho de material genético (imagem extraída do DGV em janeiro de 2014). 

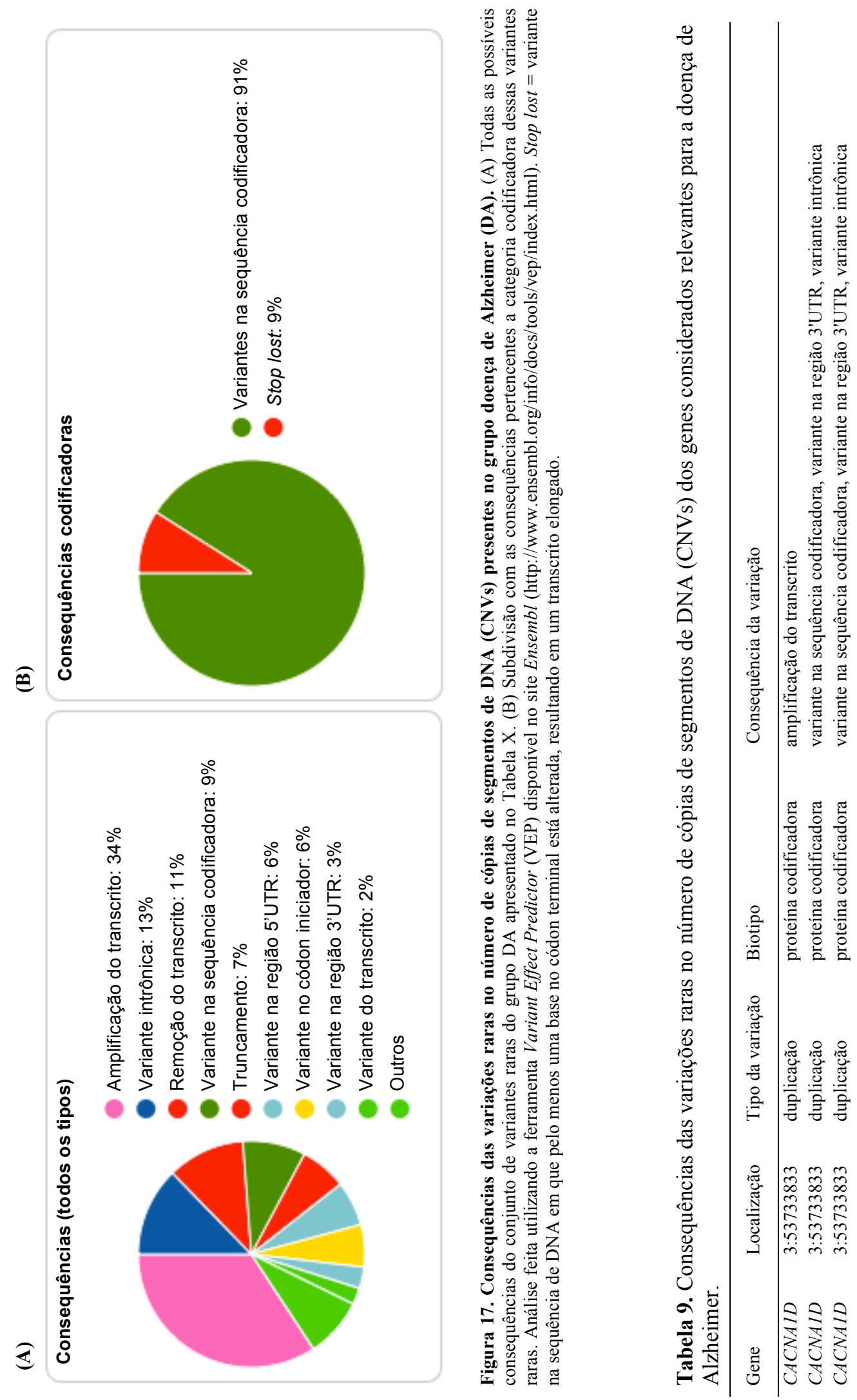

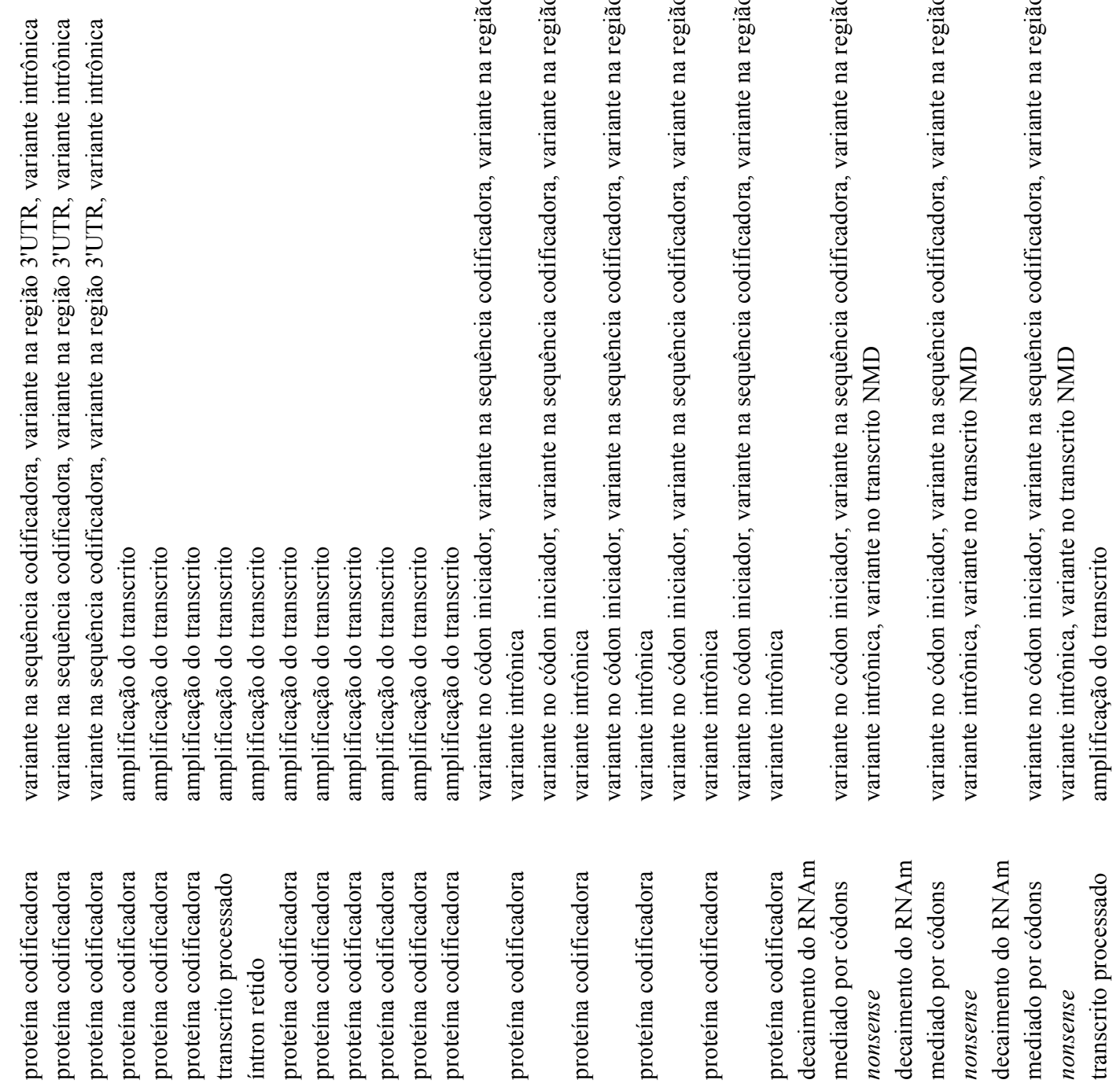

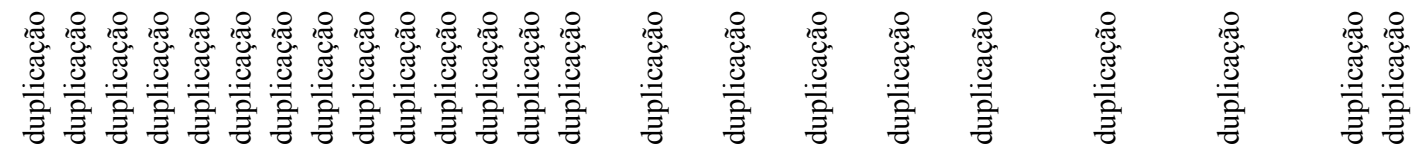

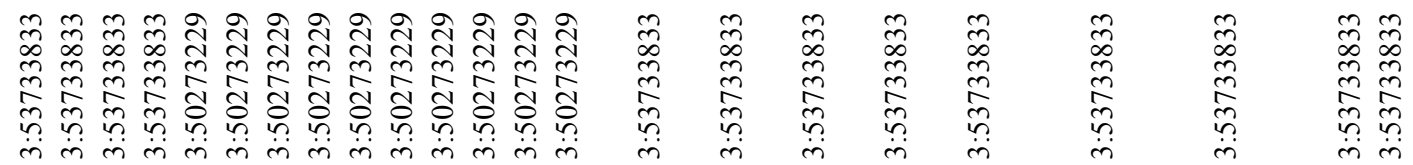

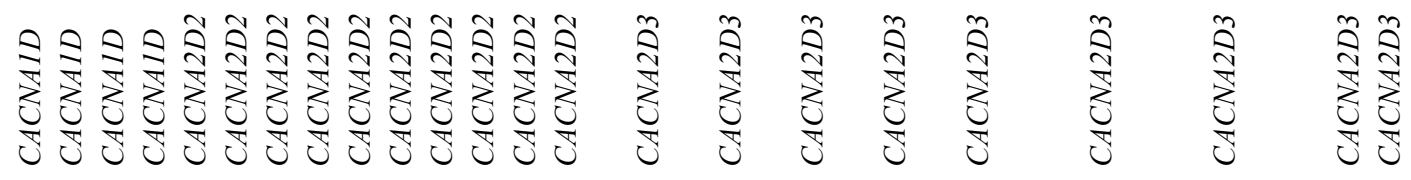




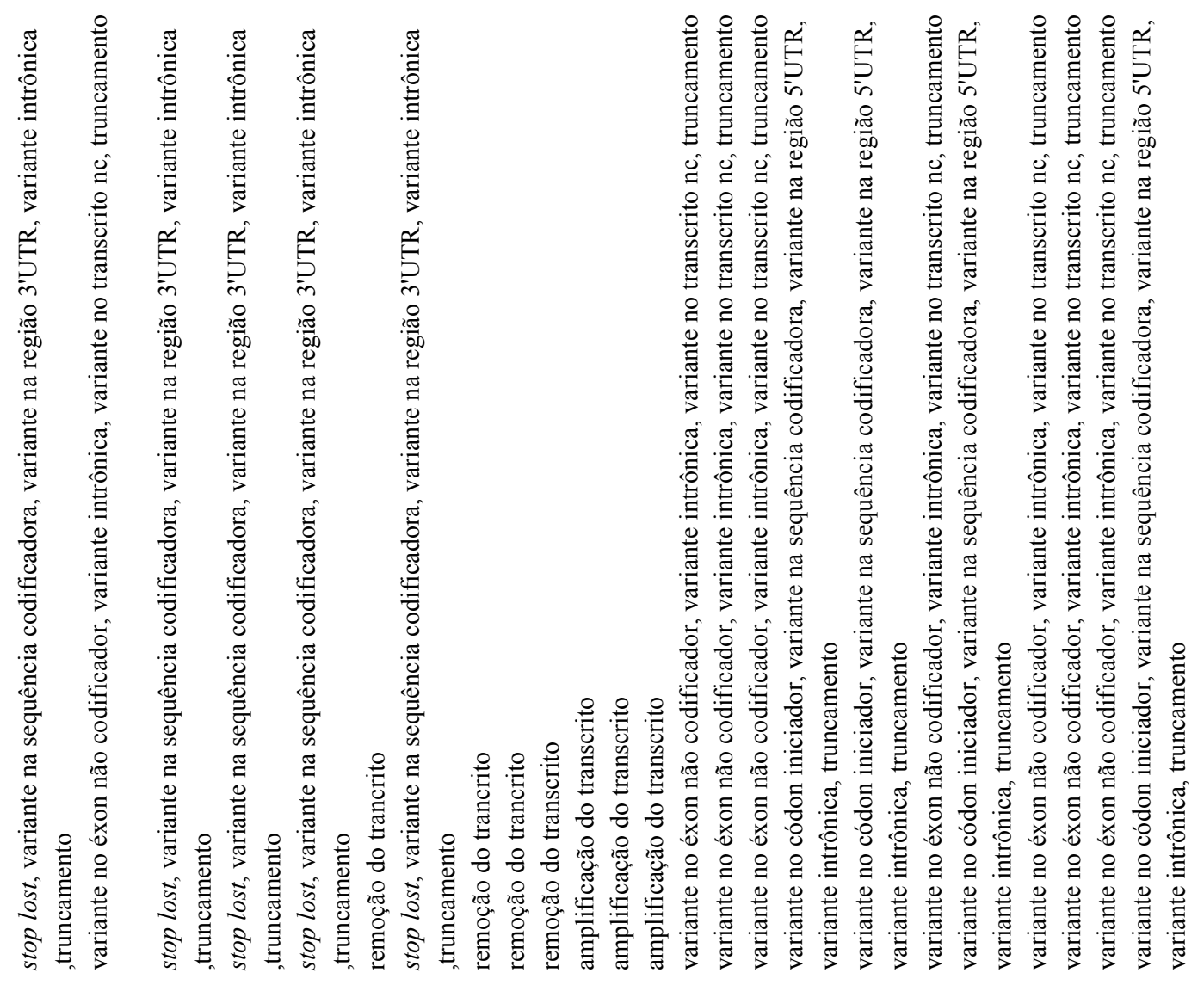

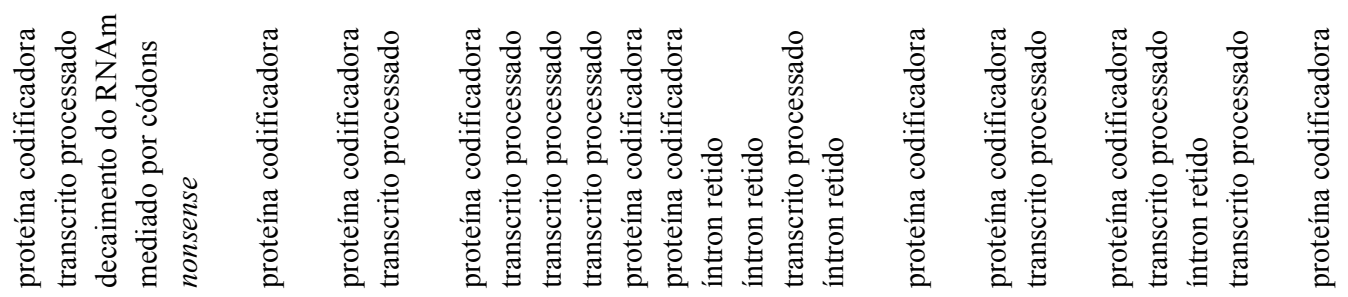

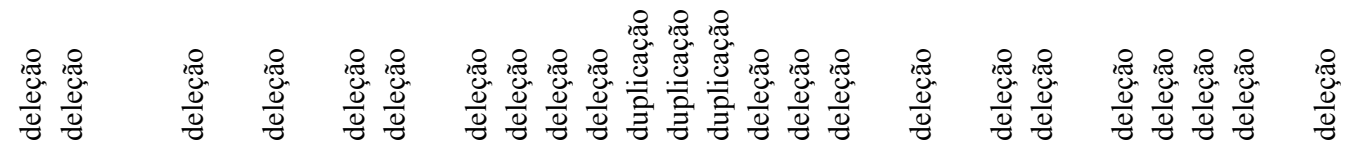

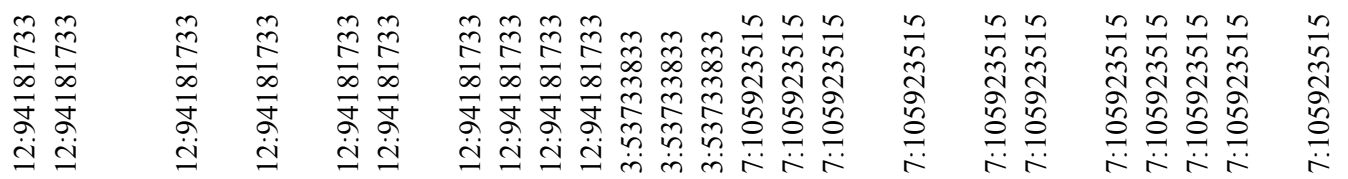

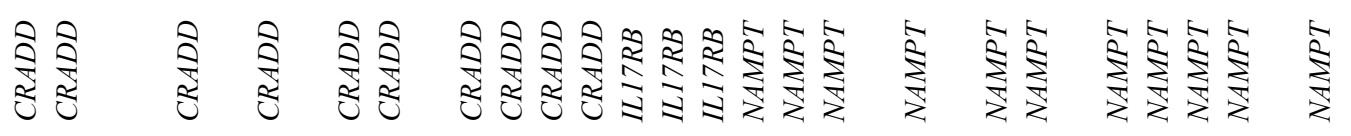




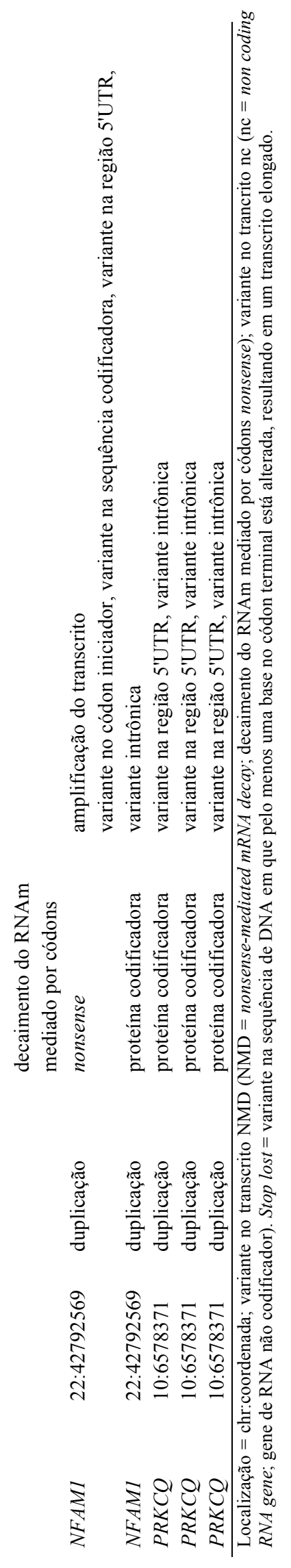


(A)

\begin{tabular}{|c|c|c|c|c|}
\hline Rede & Genes/Moléculas participantes da rede & Score & Genes especificados & Doenças e/ou Funções relacionadas \\
\hline 1 & $\begin{array}{l}\text { Akt, BMF, CACNA1D, CEACAM3, CNN1, } \\
\text { CXCL16, DIO1, FCGR1B, GCH1, HSP, } \\
\text { HSPB7, HSPG2, IFIT3, IFNG, IL17RB, } \\
\text { KRT15, LAIR1, MAGEA3/MAGEA6, } \\
\text { MARCKSL1, MYOCD, NAMPT, OAS2, } \\
\text { OASL, OGG1, PIK3CB, PLA2G5, PLA2G2A, } \\
\text { PRKCQ, PTGDR, RASSF1, SEMA3B, TNF, } \\
\text { TYMP, ULBP2, VIPR1 }\end{array}$ & 12 & 7 & $\begin{array}{l}\text { Bioquímica de Moléculas Pequenas, } \\
\text { Interação e Sinalização Célula-Célula, } \\
\text { Função e Desenvolvimento do Sistema } \\
\text { Hematológico }\end{array}$ \\
\hline
\end{tabular}

(B)

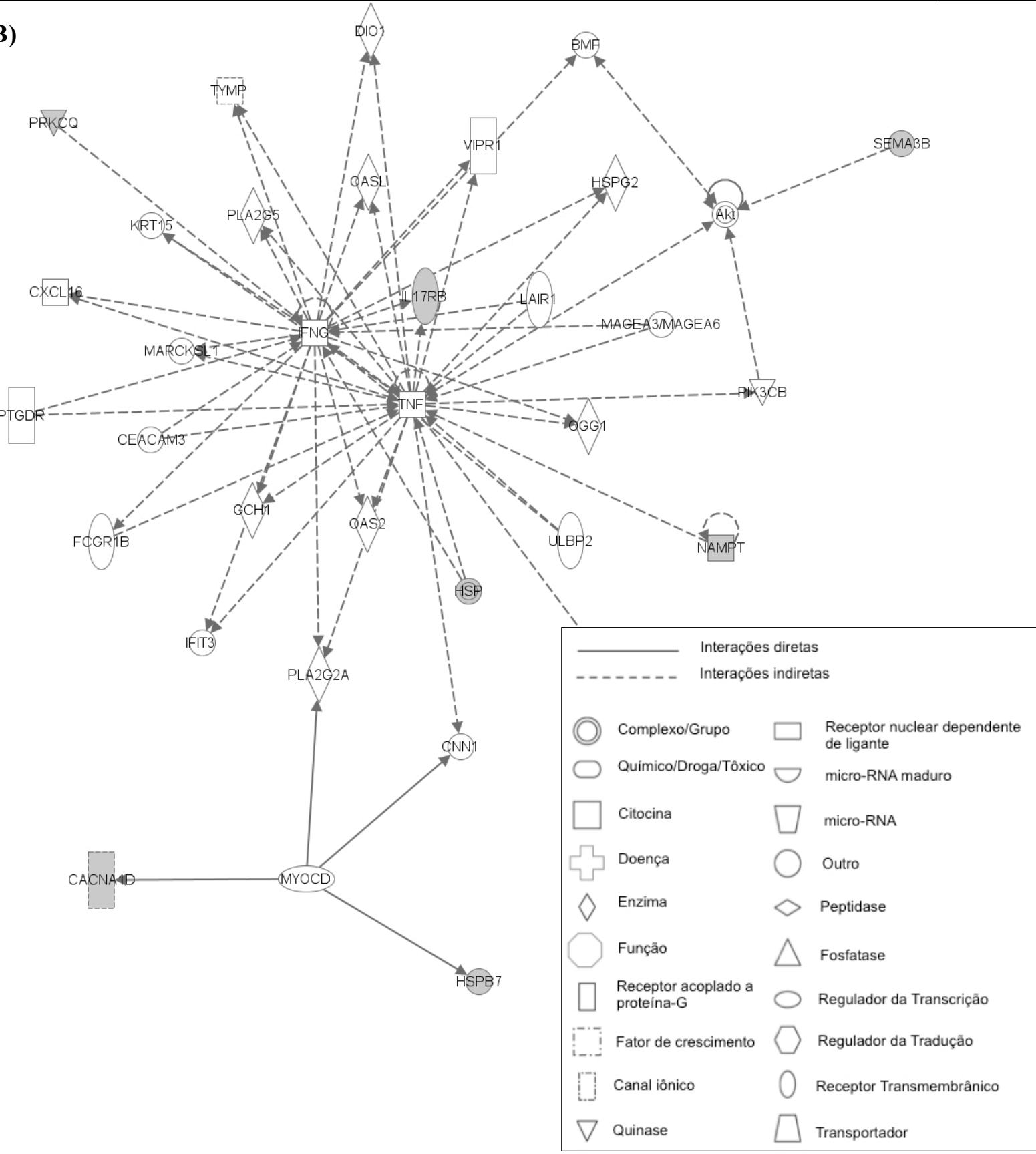

Figura 18. Análise de redes de interação molecular realizada através do programa computacional Ingenuity Pathway Analysis. (A) O quadro mostra a única rede identificada pelo programa e o score que foi atribuído a ela. O score representa o número de genes/moléculas presentes na rede, criada a partir dos genes especificados (destacados em negrito) que foram extraídos da Tabela 8, ou seja, todos os genes alterados pelos desequilíbrios genômicos raros encontrados no grupo doença de Alzheimer, sejam eles considerados relevantes ou não para o fenótipo investigado. (B) Representação gráfica da rede identificadas pelo programa. A rede 
apresentada no quadro acima encontra-se retratada em (B) e está relacionada com bioquímica de moléculas pequenas, interação e sinalizaçãoo célula-célula e função e desenvolvimento do sistema hematológico. Os genes que forma especificados para análise estão evidenciados em cinza na rede. Para formar uma rede o programa computacional Ingenuity Pathway Analysis adiciona genes/moléculas (em branco) para preencher áreas que estejam faltando na conectividade.

Top Funções Biológicas

\begin{tabular}{llc}
\hline Doenças & \multicolumn{1}{c}{$P$-valor } & Moléculas \\
Doença do Sistema Auditivo & $8,82 \mathrm{E}-06-8,98 \mathrm{E}-03$ & 4 \\
Doença do Sistema Endócrino & $8,82 \mathrm{E}-06-3,00 \mathrm{E}-03$ & 6 \\
Doença Hereditária & $8,82 \mathrm{E}-06-2,38 \mathrm{E}-02$ & 4 \\
Doença Metabólica & $8,82 \mathrm{E}-06-4,41 \mathrm{E}-02$ & 8 \\
Doença Neurológica & $8,82 \mathrm{E}-06-4,30 \mathrm{E}-02$ & 3 \\
\hline Funções Moleculares e Celulares & & 2 \\
Metabolismo de Carboidratos & $2,64 \mathrm{E}-05-1,79 \mathrm{E}-02$ & 4 \\
Metabolismo de Drogas & $2,64 \mathrm{E}-05-2,64 \mathrm{E}-05$ & 4 \\
Bioquímica de Moléculas Pequenas & $2,64 \mathrm{E}-05-3,25 \mathrm{E}-02$ & 5 \\
Crescimento e Proliferação Celular & $4,31 \mathrm{E}-05-4,12 \mathrm{E}-02$ & 2 \\
Movimento Celular & $1,17 \mathrm{E}-03-4,70 \mathrm{E}-02$ & 2 \\
\hline Função e Desenvolvimento dos Sistemas & & 2 \\
Fisiológicos & & 1 \\
Função e Desenvolvimento do Sistema Nervoso & $1,17 \mathrm{E}-03-5,99 \mathrm{E}-03$ & 1 \\
Morfologia Tumoral & $3,00 \mathrm{E}-03-1,79 \mathrm{E}-02$ & 2 \\
Desenvolvimento Embrionário & $5,99 \mathrm{E}-03-4,12 \mathrm{E}-02$ & $5,03 \mathrm{E}-03-5,99 \mathrm{E}-03$ \\
Função e Desenvolvimento Epidermal & $5,99 \mathrm{E}-03-5,99 \mathrm{E}-03$ & \\
Função e Desenvolvimento do Sistema Renal & & \\
\hline
\end{tabular}

Figura 19. Associação dos genes considerados diferencialmente metilados com diferentes funções biológicas. O programa computacional Ingenuity Pathway Analysis ranqueia as cinco funções mais significantes dos genes em relação à diferentes categorias de funções biológicas e atribui um $P$-valor a cada uma delas. $P$ valor está apresentado em notação científica $(\mathrm{E}=$ Exponte) .

Ainda em relação ao nosso estudo sobre CNVs na DA, como nós trabalhamos com amostras de tecidos diferentes, ao fazer a análise estatística de todos os dados de array-CGH, investigamos também se existia uma diferença acerca do número total de CNVs detectadas em sangue versus cerebelo, independentemente das amostras pertencerem ao grupo controle ou DA. A análise dos resultados mostra que em cerebelo existe um aumento significativo no número total de CNVs em comparação às amostras de sangue $(P<0,001$; teste $\mathrm{U}$ de MannWhitney) (Figura 20A). Em seguida, analisamos se esta diferença era igualmente mantida em nossos dois grupos de estudo. A Figura 20B mostra que de fato, em ambos os grupos (controle e DA), existe uma maior detecção do número total de CNVs em cerebelo em relação as amostras de sangue $(P<0,01$; teste $\mathrm{U}$ de Mann-Whitney). Logo, para validar nossos dados, estudamos amostras pareadas de 19 indivíduos controle, ou seja, examinamos e comparamos 
amostras de sangue e cerebelo do mesmo sujeito. Exceto por um, todos os indivíduos analisados verdadeiramente apresentam um maior número de CNVs no cerebelo $(P<0,001$; teste U de Mann-Whitney) (Figura 21). Para um estudo mais detalhado, classificamos as CNVs em constitutivas (presentes no sangue e cerebelo) e não constitutivas (presentes só no sangue ou só no cerebelo) e as comparamos com respeito ao tamanho e densidade gênica. Vale destacar que somente 4 sujeitos apresentam CNVs não constitutivas presentes só no sangue. Apesar do $n$ reduzido nesse grupo específico de CNVs dificultar a análise estatística dos nossos dados, é possível observar que existe uma diferença quanto à variância das médias no tamanho das CNVs, em especial, as deleções. Tanto as deleções constitutivas quanto as não constitutivas do cerebelo são maiores do que as não constitutivas do sangue $(P<0,001$; Teste de Bartlett). Além disso, a densidade gênica das CNVs não constitutivas do cerebelo é significativamente menor do que as $\mathrm{CNVs}$ do sangue, tanto as constitutivas quanto as não constitutivas $(P<0,05$; One-way ANOVA; $P<0,001$; Teste de Bartlett) (Tabela 10). Levando em consideração essas informações, investigamos também se havia uma diferença no tamanho das CNVs raras entre sangue e cerebelo apresentadas nas Tabela 7 e 8. Porém, de acordo com a análise dos dados, não há diferença estatisticamente significante $(P=0,4313$; Teste U de Mann-Whitney e $P=0,66822$; Teste U de Mann-Whitney, dados referentes as Tabelas 7 e 8, respectivamente). 
(A)

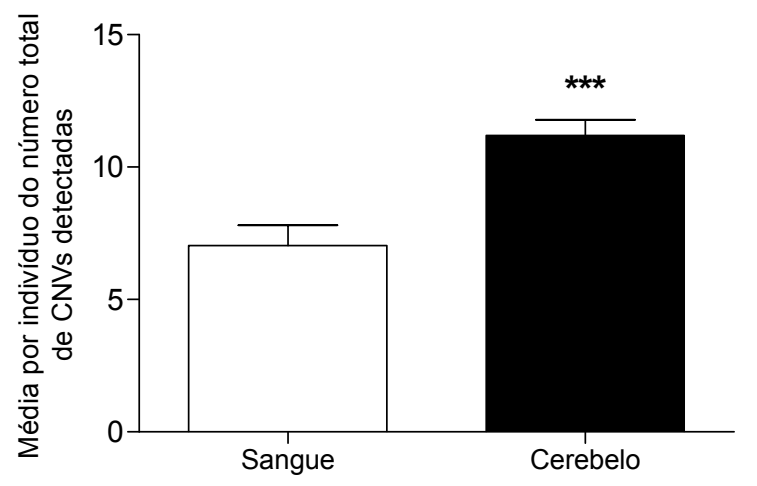

(B)

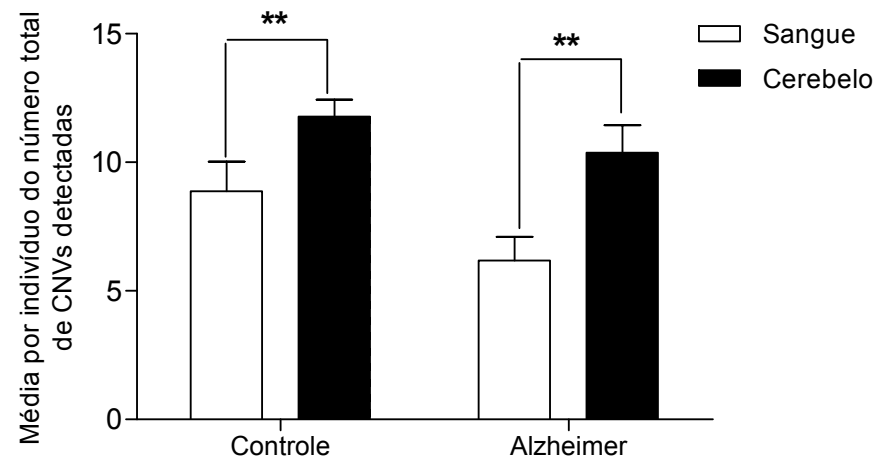

Figura 20. Média por indivíduo do número total de variações no número de cópias de segmentos de DNA (CNVs) detectadas nas análises de array-CGH em amostras de sangue versus tecido cerebral. (A) Amostras de sangue e cerebelo foram comparadas, independentemente de pertencerem a algum tipo de grupo. *** $P<$ 0,001; teste U de Mann-Whitney. (B) A diferença na detecção do número total de CNVs em cerebelo em relação as amostras de sangue foi igualmente observada nos grupos controle e doença de Alzheimer. ** $P<0,01$; teste $\mathrm{U}$ de Mann-Whitney.

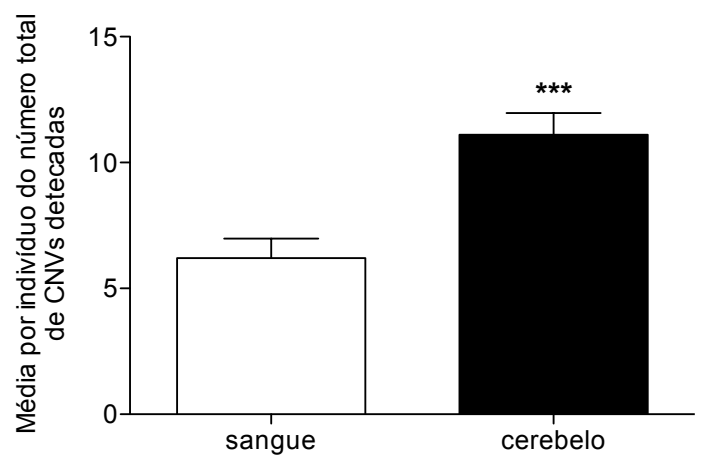

Figura 21. Média por indivíduo do número total de variações no número de cópias de segmentos de DNA (CNVs) detectadas nas análises de array-CGH em amostras pareadas de indivíduos controle. Amostras de sangue e cerebelo do mesmo sujeito foram comparadas. ***P $<0,001$; teste U de Mann-Whitney.

Tabela 10. Tamanho e densidade gênica das CNVs encontradas nos indivíduos da amostra pareada de controles.

\begin{tabular}{lccc}
\hline & CNVs constitutivas & $\begin{array}{c}\text { CNVs não } \\
\text { constitutivas (sangue) }\end{array}$ & $\begin{array}{c}\text { CNVs não } \\
\text { constitutivas (cerebelo) }\end{array}$ \\
\hline Tamanho médio das CNVs $(\mathrm{Kb})^{*}$ & $387.142 \pm 74.406 / n=48$ & $209.841 \pm 41.483 / n=13$ & $385.581 \pm 81.050 / n=73$
\end{tabular}


Duplicações $(\mathrm{Kb})$

Deleções $(\mathrm{Kb})^{*}$

Densidade gênica $(\mathrm{Kb}) \dagger^{*}$
$373.882 \pm 107.014 / n=27 \quad 332.526 \pm 142.358 / n=3$

$404.189 \pm 102.812 / n=21$

$177.235 \pm 28.619 / n=11$

$10.66 \pm 5.36 / n=48$
$16.33 \pm 6.49 / n=13$
$224.251 \pm 60.071 / n=21$

$450.733 \pm 110.265 / n=52$

$2.19 \pm 0.35 / n=73$

$\mathrm{CNV}=$ variação no número de cópias de segmentos de DNA. Densidade gênica $=\left(\mathrm{N}^{\circ}\right.$ de genes presentes na CNV/Tamanho da CNV) x 1.000.000. $\uparrow$ One-way ANOVA $P<0,05$; *Teste de Bartlett $P<0,05$; Os valores estão apresentados como média \pm SEM.

\section{Parte II. Estudo do padrão de metilação do DNA na Doença de Alzheimer (DA)}

O status de metilação de cada sítio $\mathrm{CpG}$ investigado na plataforma 450K da Illumina é apresentado após análise no programa computacional GenomeStudio como valores entre 0 e 1 (valores de beta), 0 indicando um sítio totalmente desmetilado e 1 indicando metilação total. A Figura 22A e B mostra a distribuição das ocorrências dos valores de beta referentes ao status de metilação dos 471.994 sítios $\mathrm{CpG}$ investigados nos grupos controle e DA. É possível observar que em ambos os grupos existem dois grandes agrupamentos dos valores de beta, um deles entre $0-0,1$, e outro entre $0,7-1$, correspondendo cada um desses picos a loci hipo e hipermetilados, respectivamente. As imagens mostram que essa distribuição bimodal dos níveis de metilação, característica de diversos tecidos, é muito similar e não apresenta diferenças evidentes entre nossos dois grupos de estudo. Para classificar os sítios CpG diferencialmente metiladas em nosso grupo de estudo, utilizamos como critério aqueles que apresentassem uma diferença $\geq 20 \%$ no valor de Delta Beta (diferença de metilação entre DA e controles), ou seja, somente os que apesentassem valor maior que 0,2 ou menor que $-0,2$ foram consideradas significativas (Figura 23A e B).

(A)

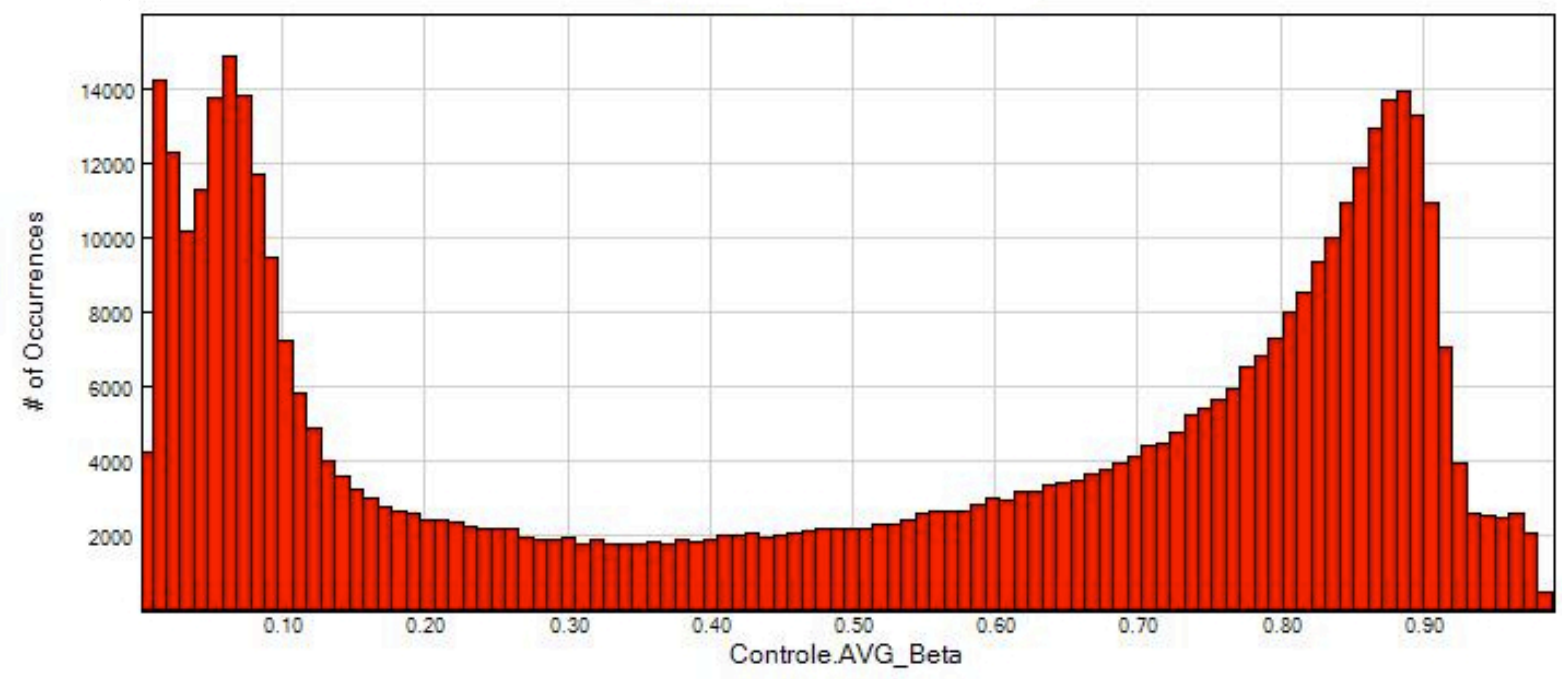




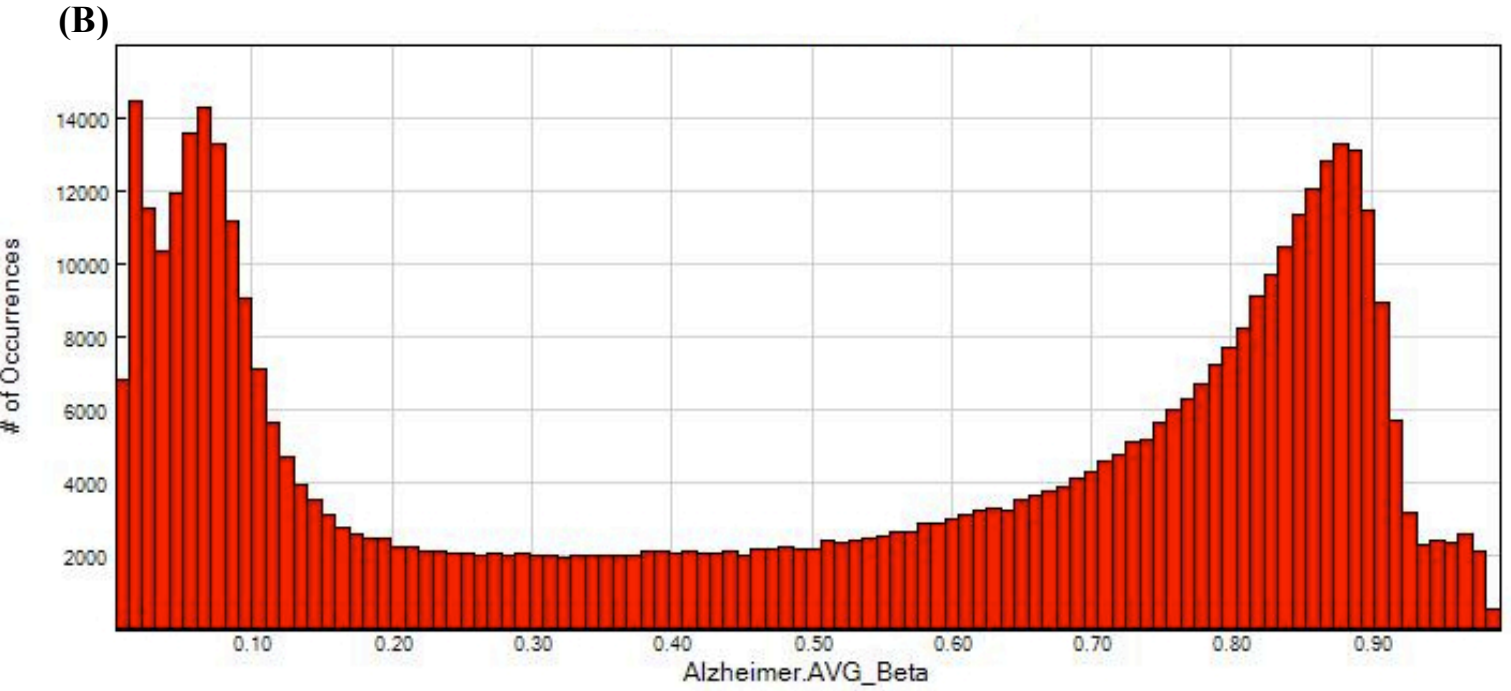

Figura 22. Distribuição da frequência dos níveis de metilação nos grupos controle (A) e doença de Alzheimer (B) nos 471.994 sítios CpG presente na plataforma 450K da Illumina (Infinium Human Methylation 450K BeadChips). Imagens extraídas do programa computacional Genome Studio.

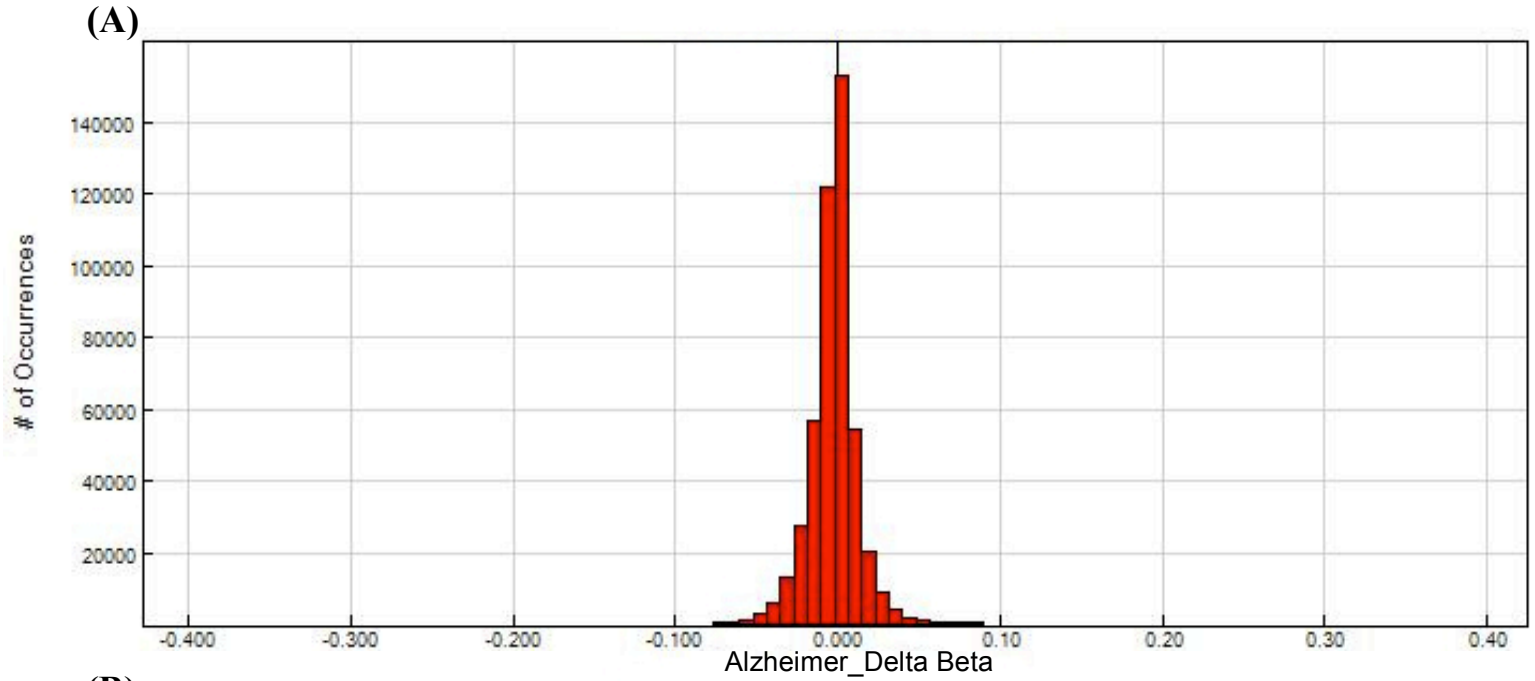

(B)

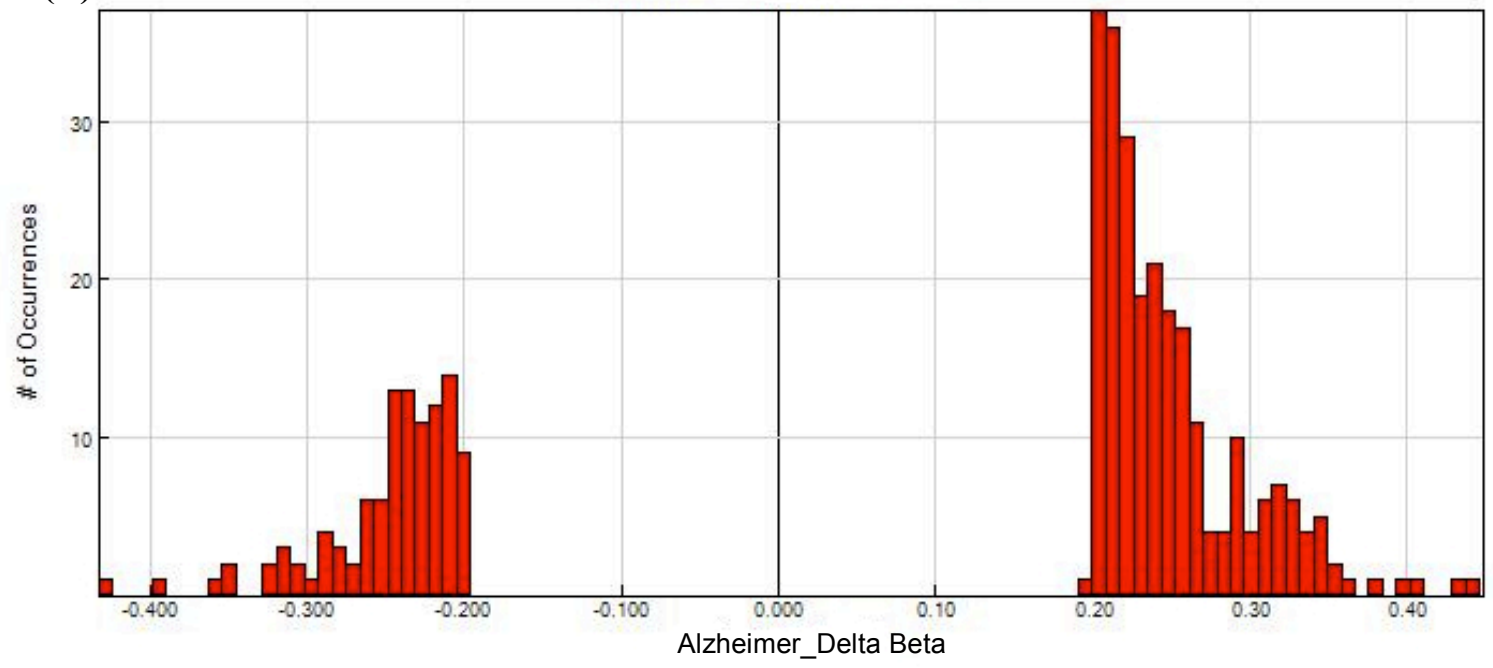

Figura 23. Distribuição dos valores de Delta Beta e CpG considerados diferencialmente metilados. (A) Valores de Delta Beta. (B) Foram considerados significativos os CpG que apresentassem uma diferença $\geq 20 \%$ 
no valor de Delta Beta, ou seja, valor maior que 0,2 ou menor que -0,2. Imagens extraídas do programa computacional Genome Studio.

Dentre os 471.994 sítios $\mathrm{CpG}$ analisados na plataforma 450K da Illumina, somente 250 loci passaram em nosso critério de significância sendo que $60 \%$ deles correspondem a loci hipermetilados e 40\% a hipometilados (Figura 24A). Analisando a distribuição genômica funcional dos loci diferencialmente metilados, no grupo dos hipermetilados a maioria se localiza nas regiões intergênicas e corpo de genes (34\% e 37\%, respectivamente), $21 \%$ na região promotora (Figura 24B) e $8 \%$ na região 3'UTR. Observamos uma distribuição semelhante também no grupo dos hipometilados, com a proporção dos loci diferencialmente metilados dividindo-se entre as regiões intergênicas, corpo de genes, promotora e 3'UTR $(32 \%, 37 \%, 28 \%$ e 3\%, respectivamente) (Figura 24C). Com relação às ilhas $\mathrm{CpG}$ e áreas adjacentes, a maioria dos loci diferencialmente metilados, em ambos os grupos, encontra-se em regiões open sea (Figura 24D e E). Vale destacar que dentre os 250 loci diferencialmente metilados, 165 estão associados a genes (todos os esses 250 sítios $\mathrm{CpG}$ considerados diferencialmente metilados entre os grupos controle e DA estão apresentados no item Material Suplementar na Tabela S1). Porém, seguindo nossos critérios para análise dos dados de metilação, após a exclusão de sondas inespecíficas, de sondas que não estão associadas a genes e daquelas que contém similaridade superior a 20 pares de bases com sequências repetitivas, obtivemos ao todo 54 loci diferencialmente metilados (Tabela 11); dos quais somente 3 não estão associados a SNPs no sítio interrogado (destacados em negrito). Além disso, nenhum gene apresentou mais do que um sítio $\mathrm{CpG}$ diferencialmente metilado. 
(A)

250 loci

(B) Distribuicão genômica funcional 149 loci Hipermetilados

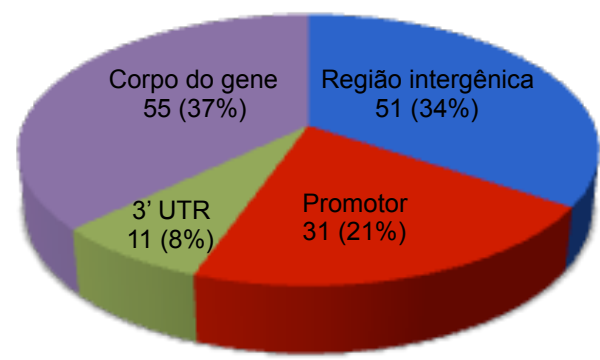

(D) Distância em relação a llha CpG 149 loci Hipermetilados

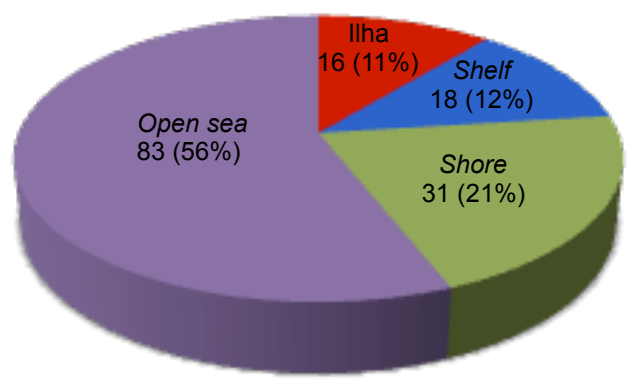

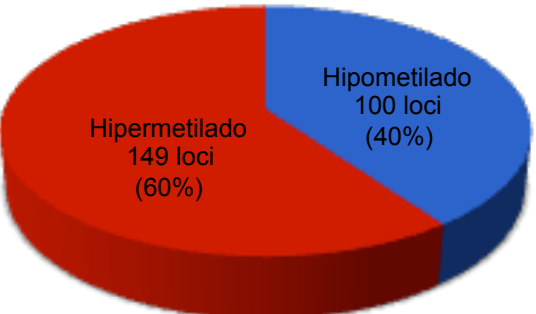

(C) Distribuicão genômica funcional 100 loci Hipometilados

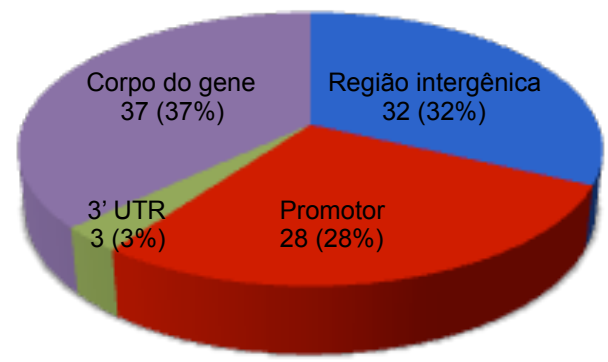

(E) Distância em relação a llha CpG 100 loci Hipometilados

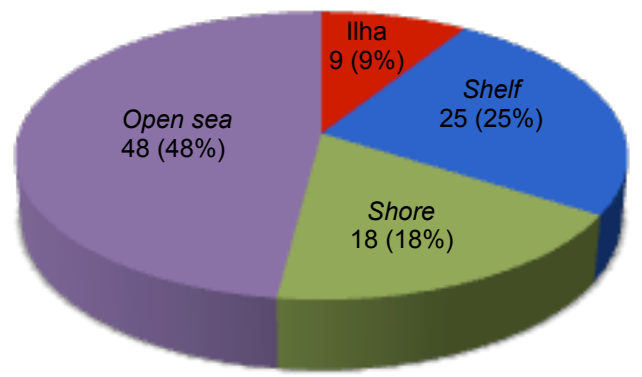

Figura 24. Visão geral do padrão de metilação do DNA na doença de Alzheimer utilizando a plataforma $450 \mathrm{~K}$ da Illumina. (A) Loci considerados diferencialmente metilados dentre os 471.994 CpG. O gráfico mostra a porcentagem dos loci hiper e hipometilados dentre os 250 considerados significativamente diferente dos controles. (B) e (C) Distribuição genômica funcional dos loci hiper e hipometilados, respectivamente. Região promotora inclui TSS1500 e TSS2200, Primeiro Exon e 5'UTR. (D) e (E) Padrão de metilação do DNA de acordo com a distância em relação a ilha $\mathrm{CpG}$ dos loci hiper e hipometilados, respectivamente. Shore - distante 0-2 Kb da Ilha CpG; Shelf - distante 2-4 Kb e Open sea - distante >4 Kb. TSS - Transcription Start Site, sítio de início de transcrição; TSS1500 e TSS 2200 - CpG localizado a 1500 e 2200 pares de base do sítio de início de transcrição, respectivamente. 


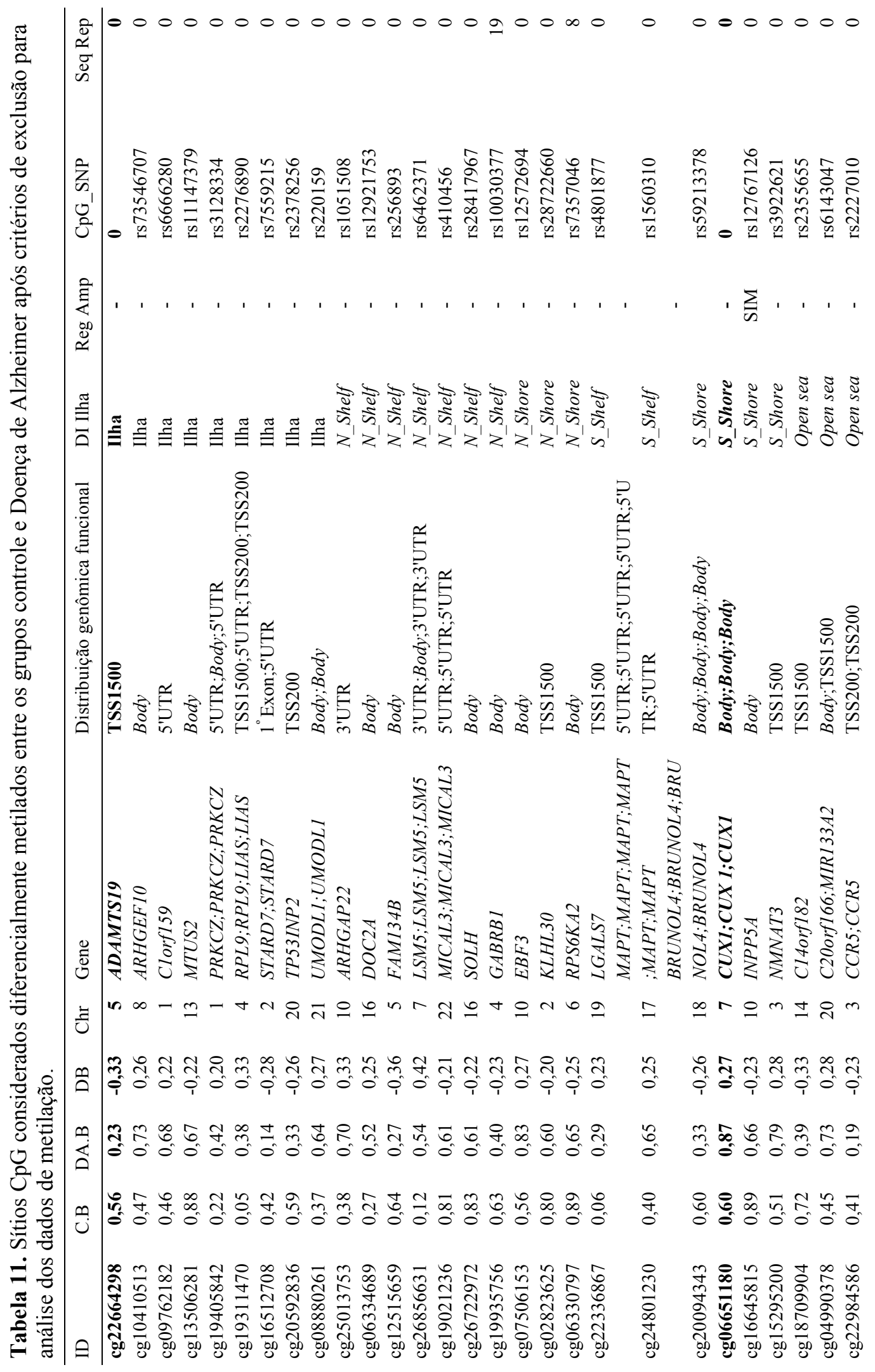




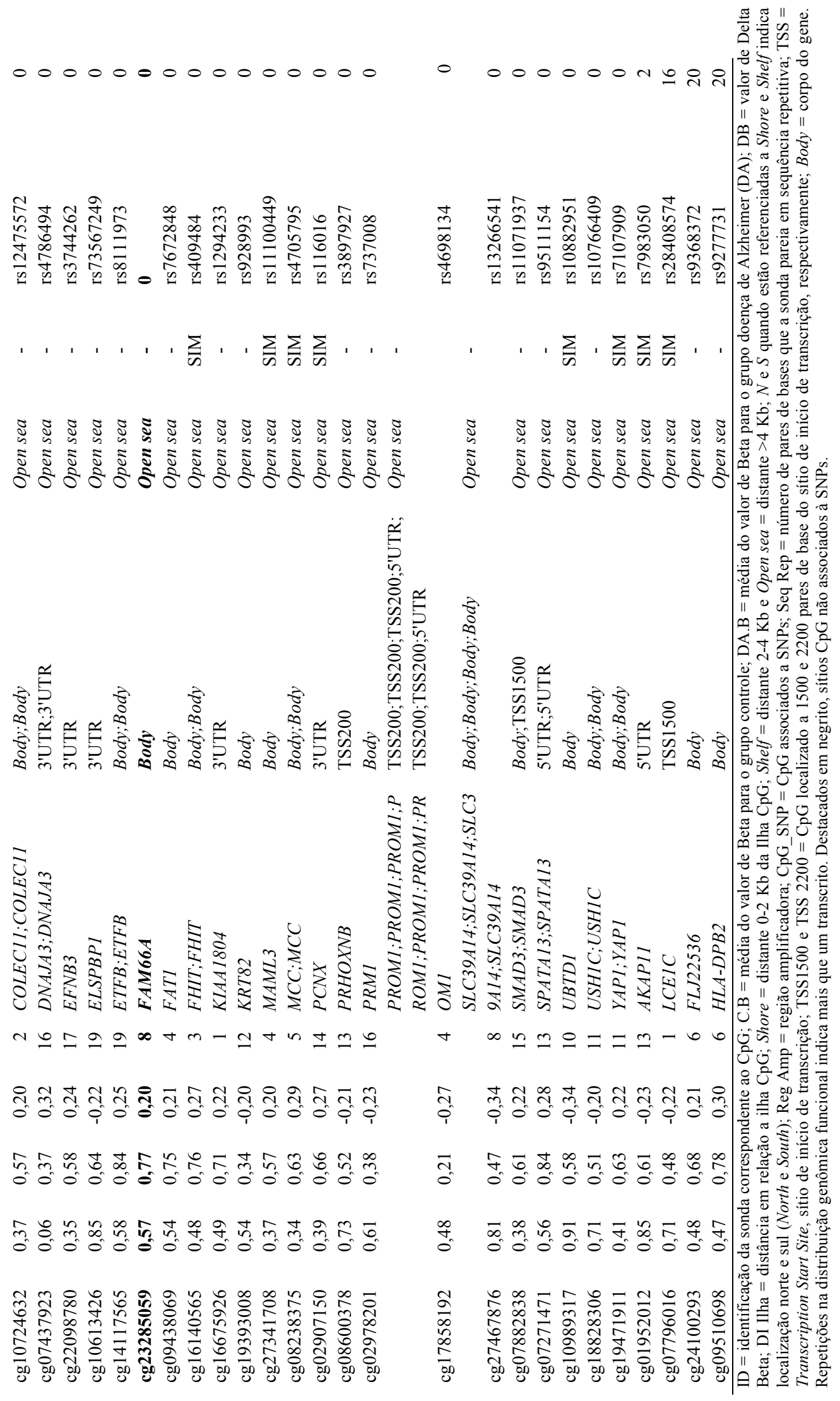


Dos 54 loci diferencialmente metilados, 30 correspondem a sítios hipermetilados e 24 a hipometilados e o maior valor de Delta Beta para cada um deles é 0,42 e -0,36, respectivamente. A clusterização hierárquica desses loci diferencialmente metilados, que visa reconhecer e agrupar as amostras mais semelhantes entre si, não separou uniformemente todas as amostras de ambos os grupos de estudo, duas do grupo controle se misturam as do grupo DA e vice-versa (Figura 25). A análise de redes de interação molecular dos genes considerados diferencialmente metilados feita programa Ingenuity Pathway Analysis identificou duas redes que foram geradas algoritmicamente, as quais estão relacionadas a doenças e/ou funções distintas. A rede 1 está associada, entre outras coisas, à sobrevivência e à morte celular; já a rede 2 está associada à movimento celular, proliferação e crescimento celular além de função e desenvolvimento do sistema hematológico (Figura 26A-C). O memso programa também ranqueou as cinco funções mais significantes dos genes em relação à diferentes categorias de funções biológicas (Figura 27).

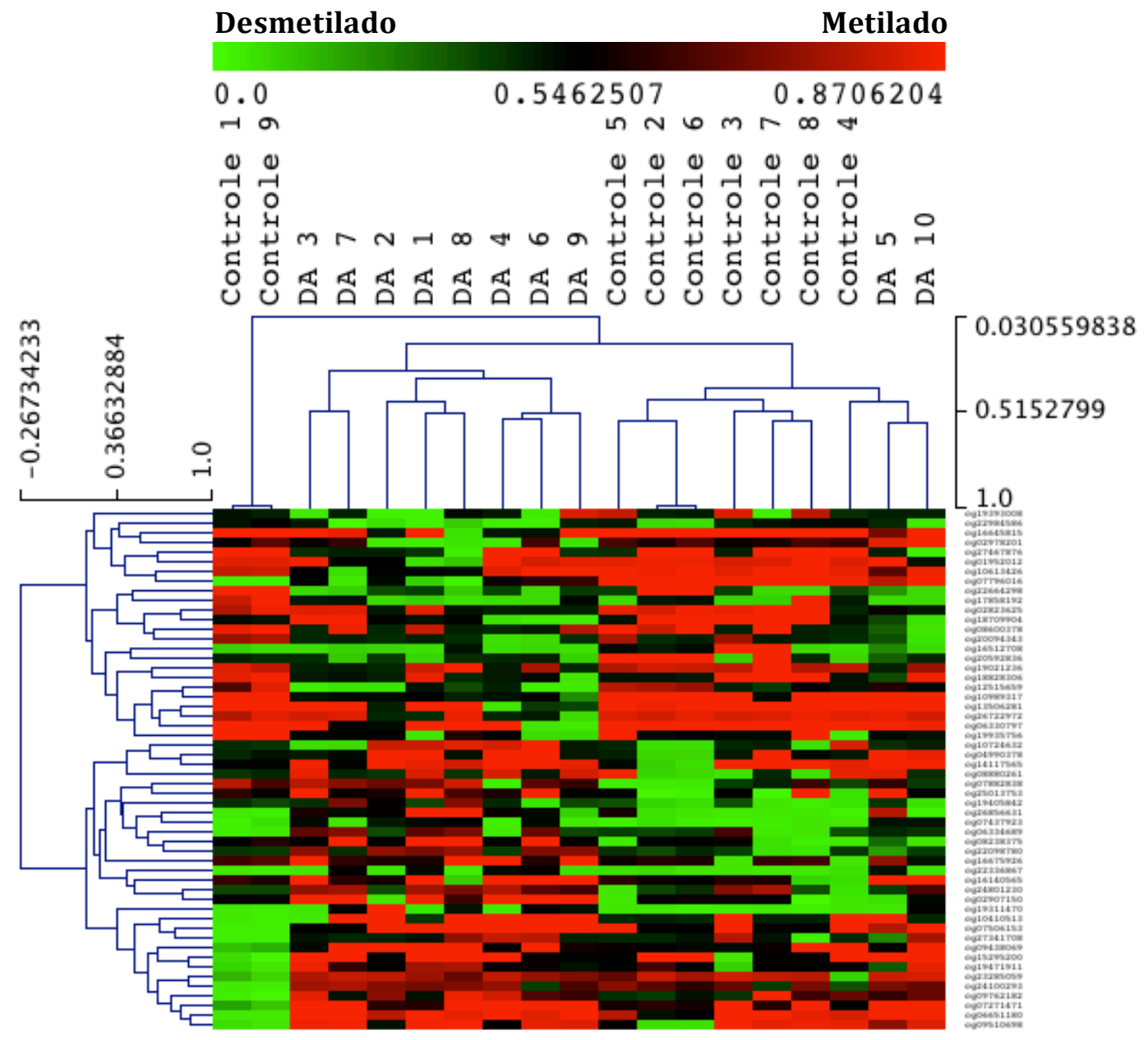

Figura 25. Cluster hierárquico dos 54 loci considerados diferencialmente metilados. Cada coluna representa uma amostra e cada linha corresponde a média dos valores de Beta para os 54 sítios CpG considerados diferencialmente metilados. A legenda das cores indica os valores equivalentes a loci desmetilados e metilados. 
A clusterização hierárquica foi feita utilizando o método Pearson Correlation através do programa computacional $\mathrm{MeV}$ 4.8.1. Imagem extraída do programa computacional MeV 4.8.1.

(A)

\begin{tabular}{|c|c|c|c|c|}
\hline Rede & Genes/Moléculas participantes da rede & Score & Genes especificados & Doenças e/ou Funções relacionadas \\
\hline 1 & $\begin{array}{l}\text { ADD1, AKAP11, ARHGAP22, } \\
\text { CDKN1A, CHI3L1, COL16A1, CUX1, } \\
\text { DNAJA3, EHF, ERG, EXT1, FHIT, GCH1, } \\
\text { GMFG, GSTA1, HSPA9, INS, IQGAP2, } \\
\text { MAPK1, MCC, mir-133, MT-CYB, NFKBIB, } \\
\text { NUMB, PRKCZ, PSMB10, RELA, ROCK2, } \\
\text { RPS6KA2, SERPINB1, SLC2A4, SLC39A14, } \\
\text { TNF, TSC22D3 }\end{array}$ & 20 & 11 & $\begin{array}{l}\text { Sobrevivência e Morte Celular, Movimento } \\
\text { Celular, Câncer }\end{array}$ \\
\hline 2 & $\begin{array}{l}\text { Akt, ANKRD1, BMF, CCR5, CDH13, CTGF, } \\
\text { EFNB3, ERBB4, FPR2, Gpcr, GSK3A, } \\
\text { GSK3B, HAVCR2, IFNG, INPP5D, LCP1, } \\
\text { LDL, LDLR, MAPT, mir-15, Nfat (family), } \\
\text { PCSK9, PIK3CA, PIK3CD, PIK3CG, PKN2, } \\
\text { PROM1, RAC1, RHOB, SEMA3B, SMAD3, } \\
\text { SPHK1, TIMP3, WWC1, YAP1 }\end{array}$ & 11 & 7 & $\begin{array}{lcc}\text { Movimento Celular, } & \text { Proliferação } \\
\text { Crescimento } & \text { Celular, } & \text { Função } \\
\text { Desenvolvimento do Sistema Hematológico, }\end{array}$ \\
\hline
\end{tabular}

(B)

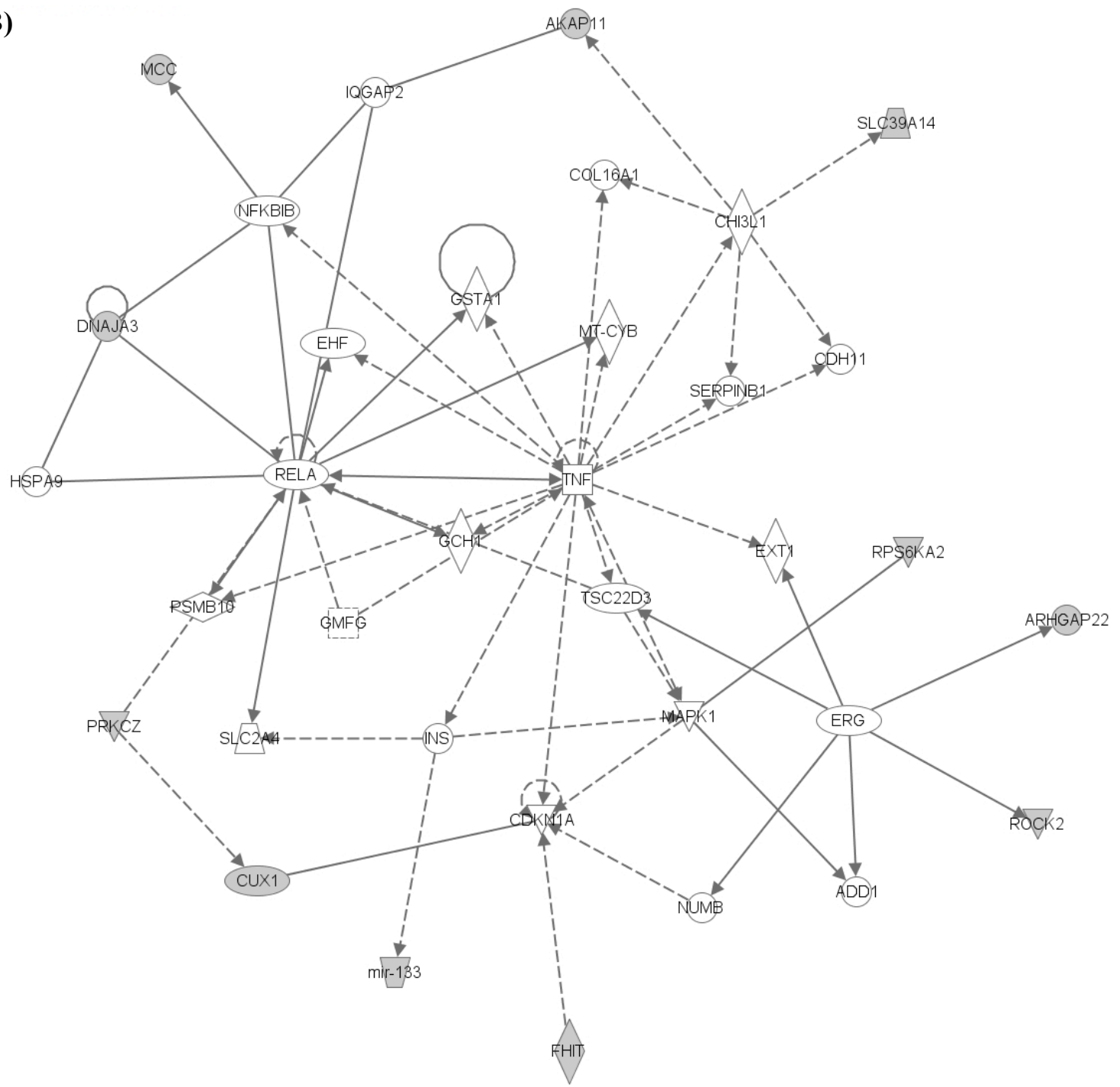


(C)

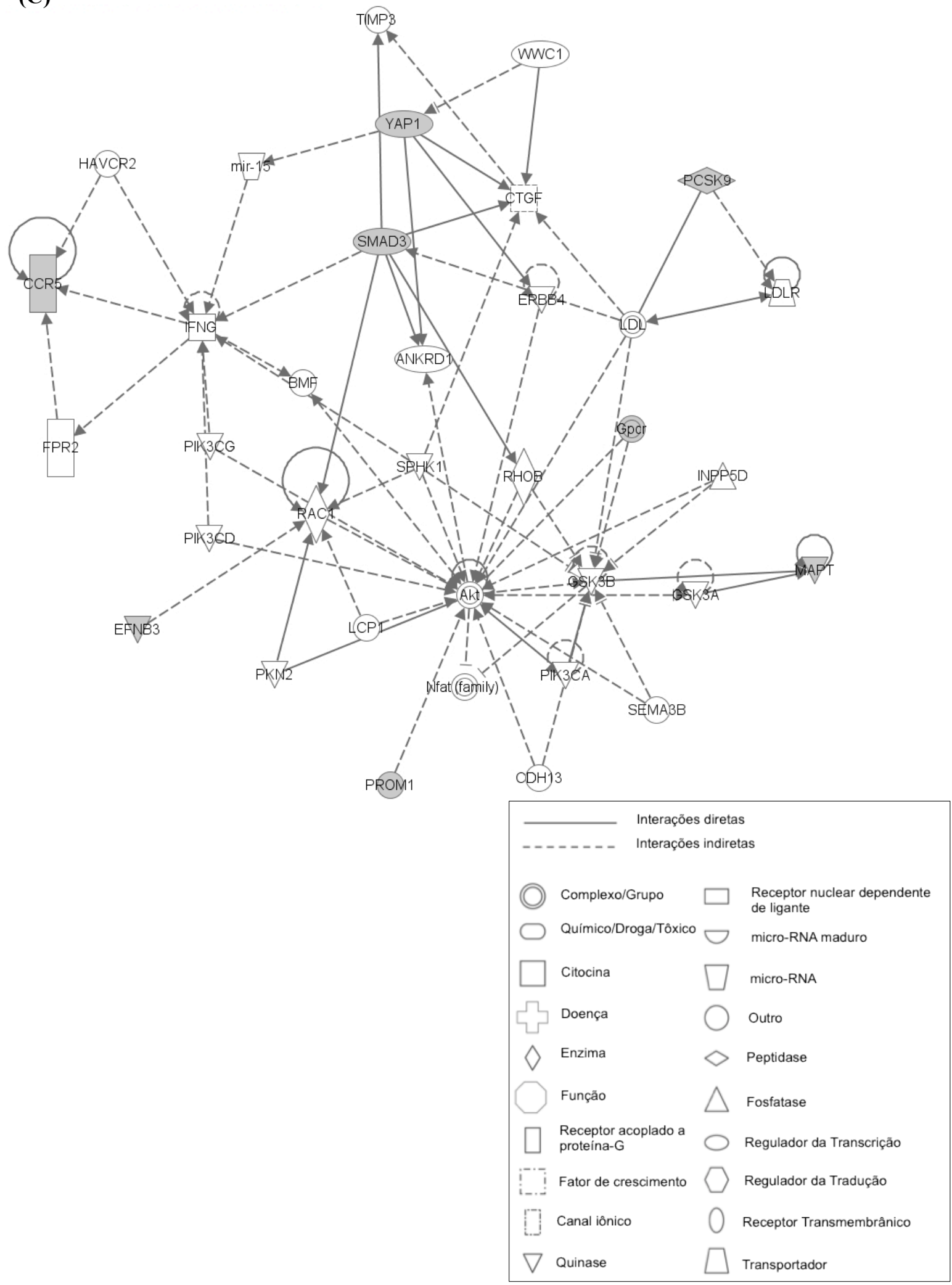

Figura 26. Análise de redes de interação molecular realizada através do programa computacional Ingenuity Pathway Analysis. (A) O quadro mostra duas redes identificadas pelo programa, o qual atribui um score a cada uma delas. O score representa o número de genes/moléculas presentes na rede, criada a partir dos genes especificados (destacados em negrito), que são os genes considerados diferencialmente metilados extraídos da Tabela 11. (B) e (C) Representação gráfica das duas redes identificadas pelo programa. A rede 1 apresentada no quadro acima encontra-se retratada em (B) e está relacionada com movimento celular, 
desenvolvimento e função do sistema hematológico e tráfego das células do sistema imune. Já a rede 2 , representada em $(\mathrm{C})$, está relacionada com interação e sinalização célula-célula, desenvolvimento e função do sistema hematológico, morte e sobrevivência celular. Em ambas as redes, os genes considerados diferencialmente metilados, estão evidenciados em cinza. Para formar uma rede o programa computacional Ingenuity Pathway Analysis adiciona genes/moléculas (em branco) para preencher áreas que estejam faltando na conectividade.

Top Funções Biológicas

\begin{tabular}{|c|c|c|}
\hline Doenças & $P$-valor & Moléculas \\
\hline Doença do Sistema Auditivo & $3,25 \mathrm{E}-03-3,25 \mathrm{E}-03$ & 1 \\
\hline Câncer & $3,25 \mathrm{E}-03-4,46 \mathrm{E}-02$ & 6 \\
\hline Doença Cardiovascular & $3,25 \mathrm{E}-03-2,89 \mathrm{E}-02$ & 4 \\
\hline Doenças do Tecido Conjuntivo & $3,25 \mathrm{E}-03-1,73 \mathrm{E}-02$ & 3 \\
\hline Doença do Desenvolvimento & $3,25 \mathrm{E}-03-1,73 \mathrm{E}-02$ & 5 \\
\hline \multicolumn{3}{|l|}{ Funções Moleculares e Celulares } \\
\hline Organização e Montagem Celular & $2,28 \mathrm{E}-05-4,77 \mathrm{E}-02$ & 10 \\
\hline Manutenção e Função Celular & 4,79E-05-4,77E-02 & 10 \\
\hline Ciclo Celular & $5,60 \mathrm{E}-04-4,50 \mathrm{E}-02$ & 6 \\
\hline Replicação, Recombinação e Reparo do DNA & $5,60 \mathrm{E}-04-1,93 \mathrm{E}-02$ & 3 \\
\hline Movimento Celular & $6,40 \mathrm{E}-04-4,77 \mathrm{E}-02$ & 10 \\
\hline \multicolumn{3}{|l|}{ Função e Desenvolvimento dos Sistemas Fisiológicos } \\
\hline Desenvolvimento Tecidual & 4,79E-05-2,99E-02 & 10 \\
\hline Função e Desenvolvimento do Sistema Visual & 7,91E-04 - 6,49E-03 & 3 \\
\hline Comportamento & $3,25 \mathrm{E}-03-3,25 \mathrm{E}-03$ & 1 \\
\hline Função e Desenvolvimento do Sistema Cardiovascular & $3,25 \mathrm{E}-03-3,25 \mathrm{E}-03$ & 1 \\
\hline Função e Desenvolvimento do Sistema Digestório & $3,25 \mathrm{E}-03-3,25 \mathrm{E}-03$ & 1 \\
\hline
\end{tabular}

Figura 27. Associação dos genes considerados diferencialmente metilados com diferentes funções biológicas. O programa computacional Ingenuity Pathway Analysis ranqueia as cinco funções mais significantes dos genes em relação à diferentes categorias de funções biológicas e atribui um $P$-valor a cada uma delas. $P$ valor está apresentado em notação científica $(\mathrm{E}=$ Exponte).

No entanto, dentre todos os loci apresentados na Tabela 11, identificamos 3 genes que consideramos especialmente interessantes para o fenótipo investigado: (1) MAPT, que codifica a proteína Tau associada a microtúbulo e conhecido por estar relacionado com várias doenças neurodegenerativas, inclusive a DA; (2) INPP5A, responsável por codificar InsP3 5 fosfatase, uma proteína que mobiliza cálcio intracelular e atua como segundo mensageiro, mediando diversas respostas celulares; e (3) NMNAT3, que codifica a enzima nicotinamida mononucleotídeo adeniltransferase 3 (NMNAT3), elemento determinante na via de biossíntese da NAD. É importante ressaltar que a metilação diferencial de MAPT e NMNAT3 ocorre na região promotora; e a de INPP5A, que acontece no corpo do gene, está relacionada com região amplificadora. Porém, nenhum dos sítios está associado à ilha $\mathrm{CpG}$. A Figura 28A mostra os valores de Delta Beta dos sítios diferencialmente metilados que correspondem 
à esses 3 genes. Vale destacar que os 3 loci estão associados a SNPs, indicando por exemplo que no caso de $M A P T$ e $N M N A T 3$, os indivíduos controle apresentando os maiores valores de Delta Beta seriam homozigotos C (hipermetilado); os que exibem valores intermediários seriam heterozigotos, pois por possuir só um alelo $\mathrm{C}$ apresentam uma perda de $50 \%$ de metilação; e aqueles com os valores próximo a zero seriam homozigotos com uma deleção do alelo C (hipometilado). A mesma figura também mostra os valores de Delta Beta dos únicos 3 sítios CpG que não estão associados a SNPs em nossa casuística e que correspondem aos genes ADAMTS19, CUX1 e FAM66A. Porém, é possível observar uma distribuição bastante semelhante à dos outros 3 loci apresentados (Figura 28B). Com relação à suas respectivas funções, ADAMTS19 codifica uma metalopeptidase envolvida no desarranjo da matriz extracelular; $C U X 1$ é responsável por codificar uma proteína que é membro da família das proteínas de ligação ao DNA, importante na progressão do ciclo celular; e FAM66A codifica um long-non coding RNA.

(A)

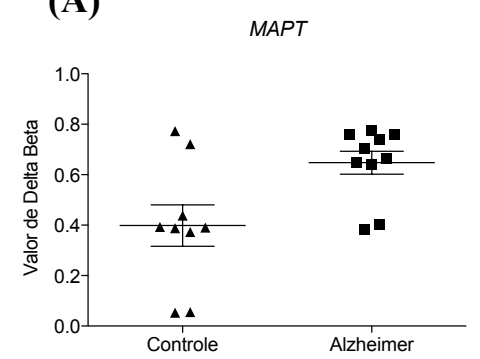

(B)

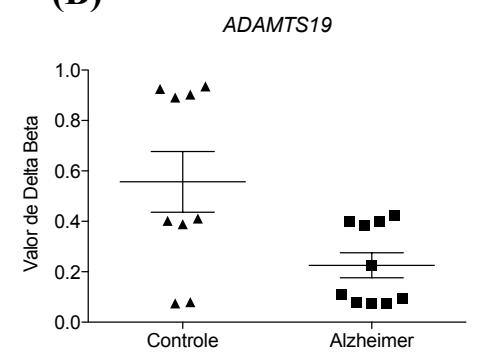

INPP5A

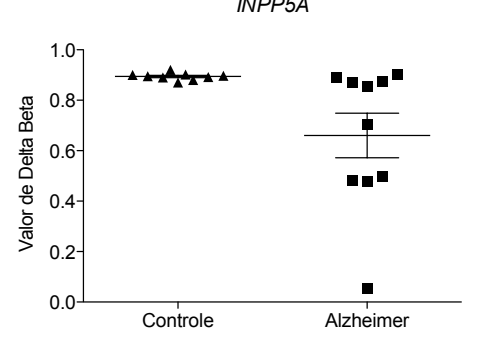

CUX1

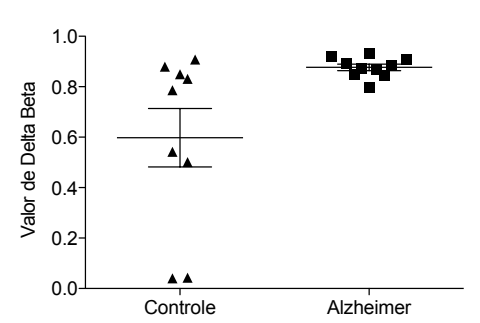

NMNAT3

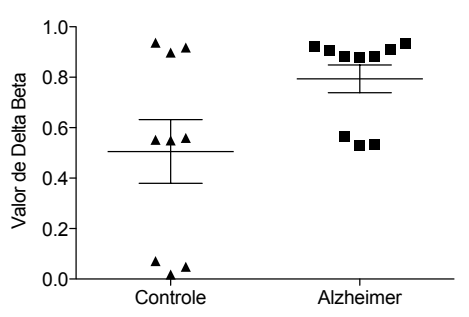

FAM66A

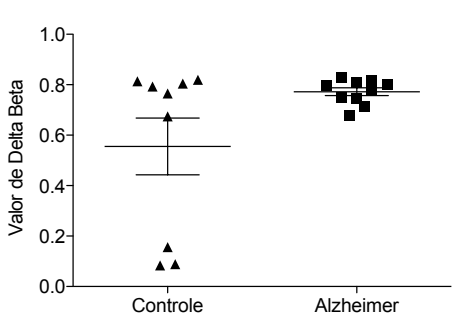

Figura 28. Valores de Beta dos sítios CpGs diferencialmente metilados associados aos genes $M A P T$, INPP5A, NMNAT3, ADAMTS19, CUX1 e FAM66A. (A) MAPT, INPP5A e NMNAT3 foram selecionados com base em sua relevância para o fenótipo investigado, no entanto, os sítios $\mathrm{CpG}$ que apresentam metilação diferencial estão associados a SNPs, indicando por exemplo que no caso de MAPT e NMNAT3 os indivíduos controle com os maiores valores de Delta Beta seriam homozigotos C; os que apresentam valores intermediários seriam heterozigotos, que por possuir só um alelo $\mathrm{C}$ apresentam uma perda de $50 \%$ de metilação; e aqueles com os valores próximo a zero seriam homozigotos com uma deleção do alelo C. (B) ADAMTS19, CUX1 e FAM66A são os únicos 3 genes em nossa casuística que apresentaram loci diferencialmente metilados não associados a SNPs. 
A distribuição dos níveis de metilação ao longo de todos os sítios $\mathrm{CpG}$ dos 6 genes discutidos anteriormente está demonstrada nas Figuras 29-34. Note que, embora em nossa análise nenhum gene tenha apresentado mais do que um sítio $\mathrm{CpG}$ diferencialmente metilado, FAM66A possui dois outros loci visivelmente alterados nos indivíduos controle que não haviam sido detectados pelo fato do valor de Delta-Beta estar ligeiramente inferior ao nosso critério de metilação diferencial (Figura 30). Logo, levando em consideração essa informação investigamos se outros genes apresentavam algum loci alterado que não tinha sido identificado em nossa análise. Examinamos os top 10 genes associados com a DA ranqueados pelo site http://www.alzgene.org (APOE, BIN1, CLU, ABCA7, CR1, PICALM, MS4A6A, $C D 33, M S 4 A 4 E$ e $C D 2 A P)$, assim como os genes alterados em nossa casuística no estudo sobre CNVs na DA (CACNA1D, CACNA2D3, CACNA2D2, PRKCQ, NFAM1, IL17RB, $C R A D D$ e $N A M P T)$. Porém, nenhum deles apresentou alteração dos níveis de metilação em algum sítio CpG (as figuras referentes à distribuição dos níveis de metilação desses genes estão apresentadas no item Material Suplementar (Figuras S1-17), com exceção de MS4A6A, pois este não está presente na plataforma $450 \mathrm{~K}$ da Illumina). 

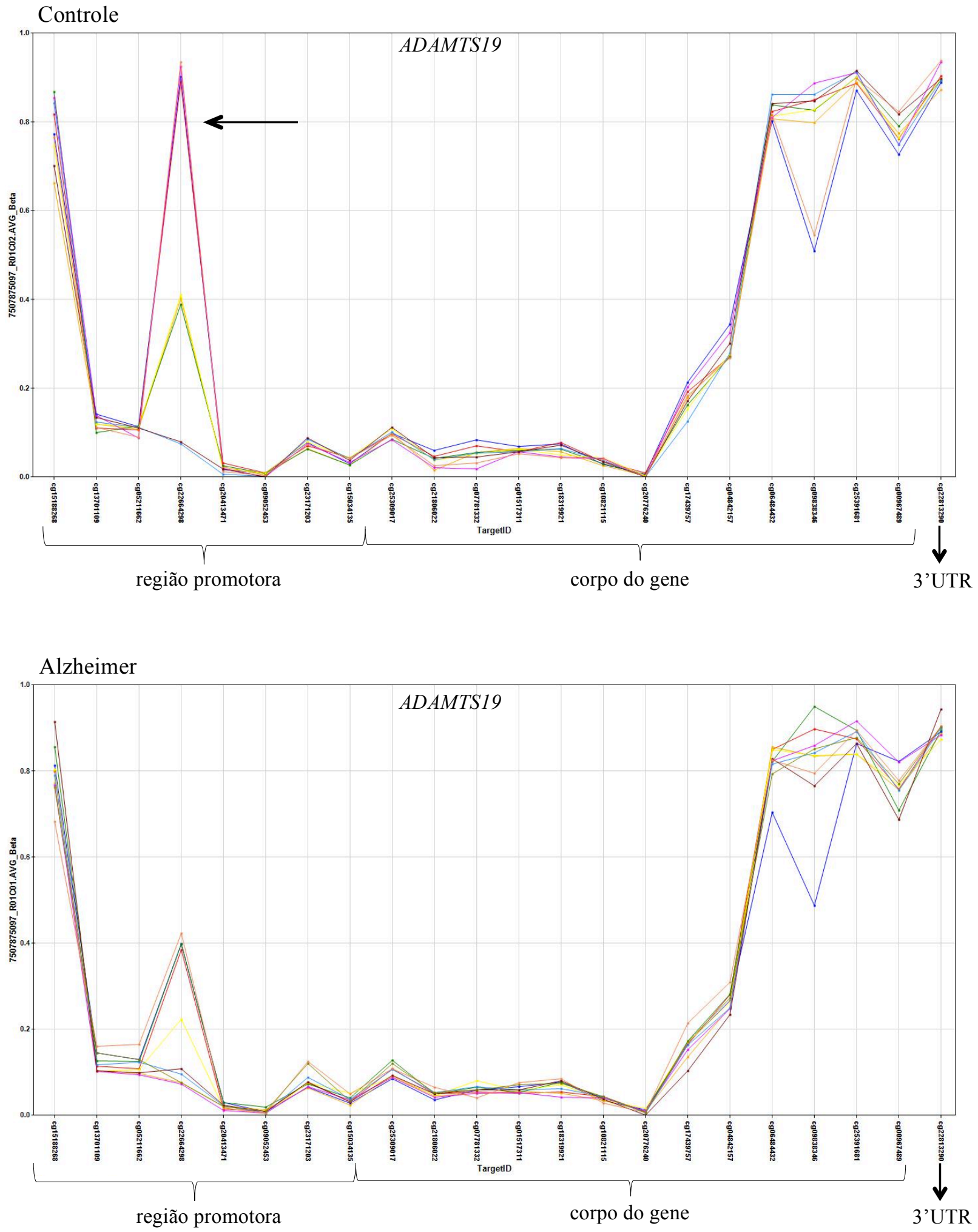

Figura 29. Distribuição dos níveis de metilação ao longo de todos os sítios CpG do gene $\boldsymbol{A D A M T S 1 9}$. Cada linha representa um indivíduo e cada ponto equivale a um sítio $\mathrm{CpG}$ com seu respectivo valor de Beta, ordenados de acordo com suas posições genômicas. A seta indica o loci diferencialmente metilado observado em nossa casuística. Imagem extraída do programa computacional Genome Studio. 

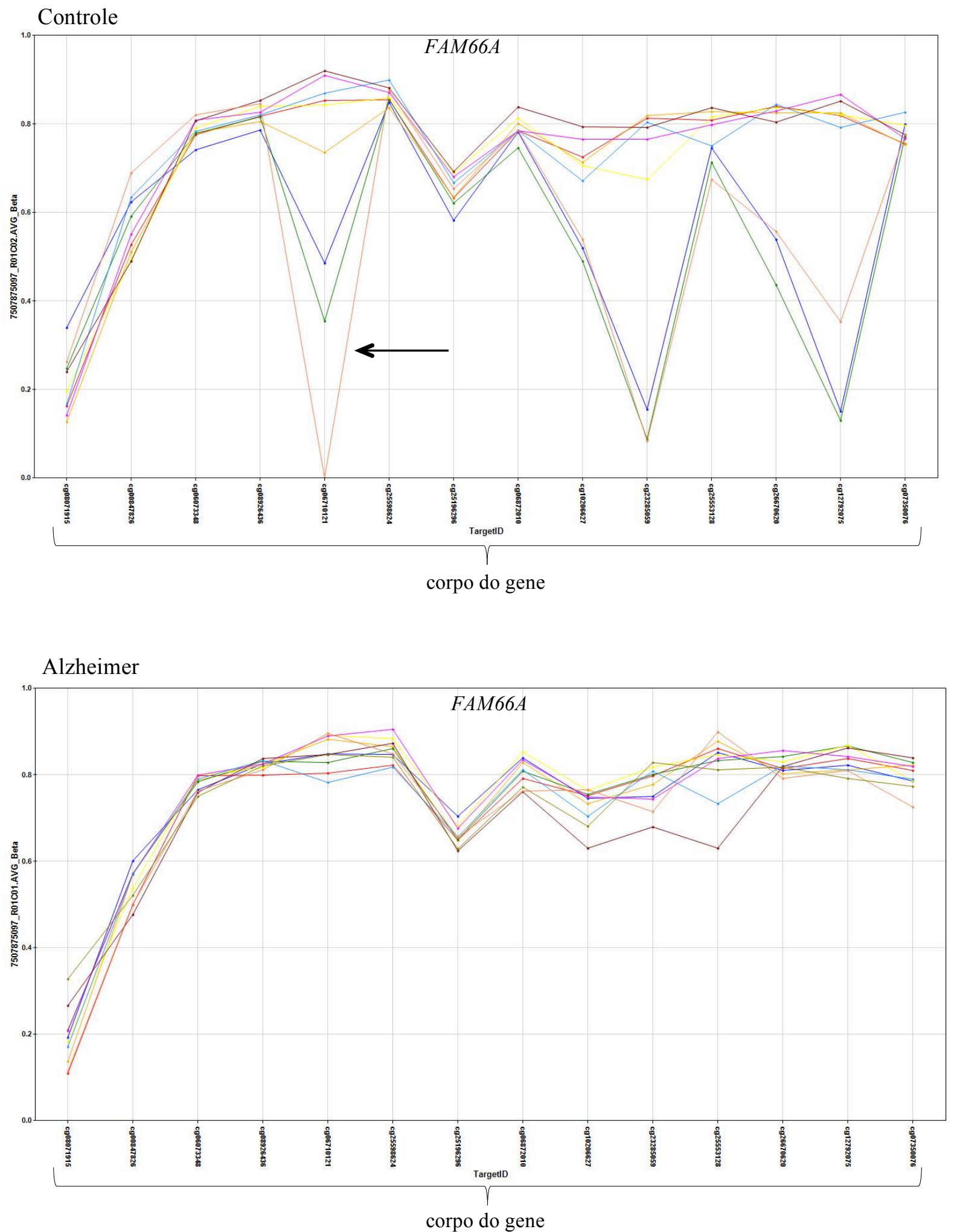

Figura 30. Distribuição dos níveis de metilação ao longo de todos os sítios CpG do gene FAM66A. Cada linha representa um indivíduo e cada ponto equivale a um sítio $\mathrm{CpG}$ com seu respectivo valor de Beta, ordenados de acordo com suas posições genômicas. A seta indica o loci diferencialmente metilado observado em nossa casuística. É possível observar que embora não foram considerados significantes em nossa análise, mais dois loci estão visivelmente alterados nos indivíduos controle. Imagem extraída do programa computacional Genome Studio. 

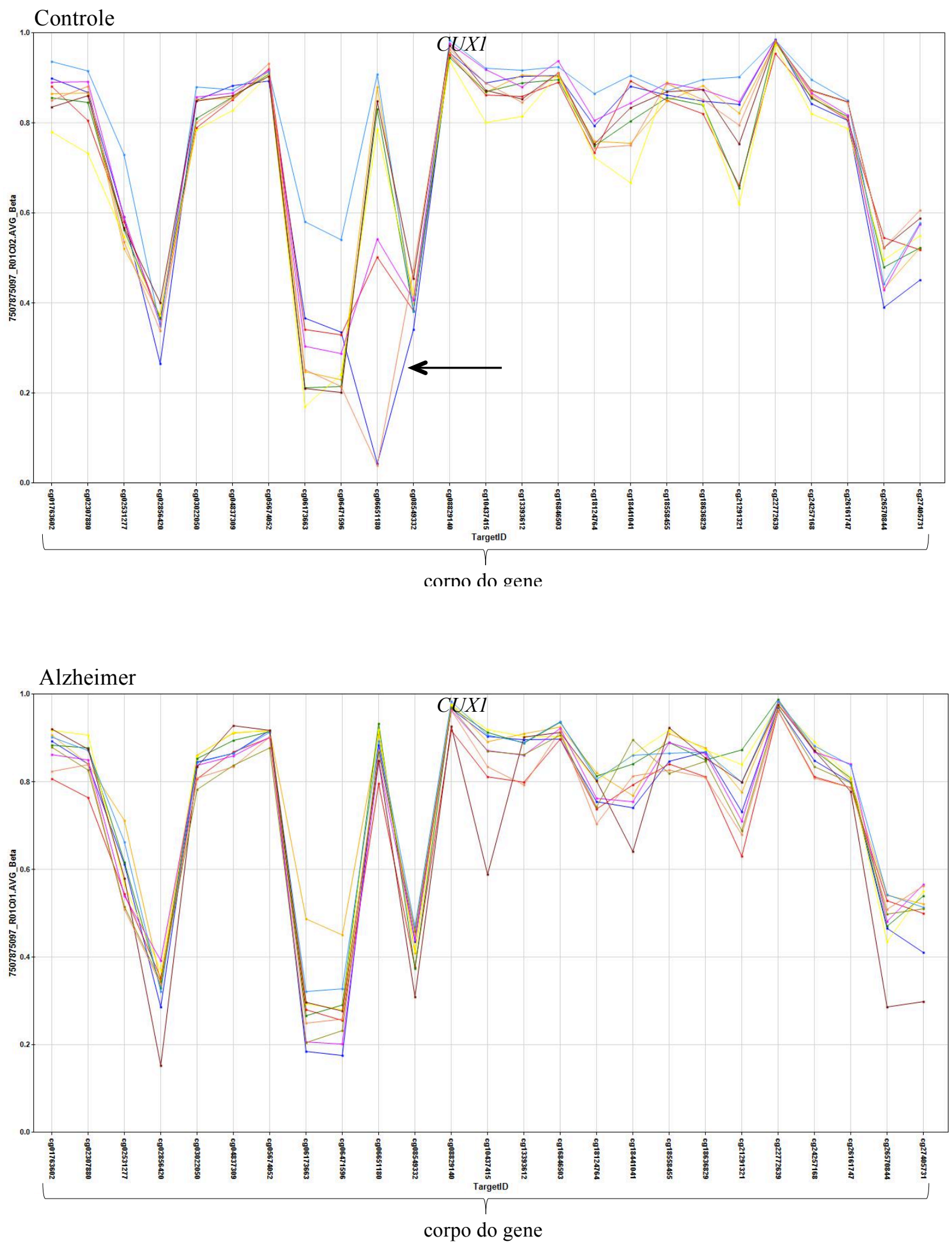

Figura 31. Distribuição dos níveis de metilação ao longo de alguns sítios CpG do gene CUX1. Cada linha representa um indivíduo e cada ponto equivale a um sítio $\mathrm{CpG}$ com seu respectivo valor de Beta, ordenados de acordo com suas posições genômicas. A seta indica o loci diferencialmente metilado observado em nossa casuística. Por ser um gene grande, o qual possui uma cobertura grande de $\mathrm{CpG}$, selecionamos alguns sítios $\mathrm{CpG}$ upstream e downstream para melhor visualização do resultado. Imagem extraída do programa computacional Genome Studio. 

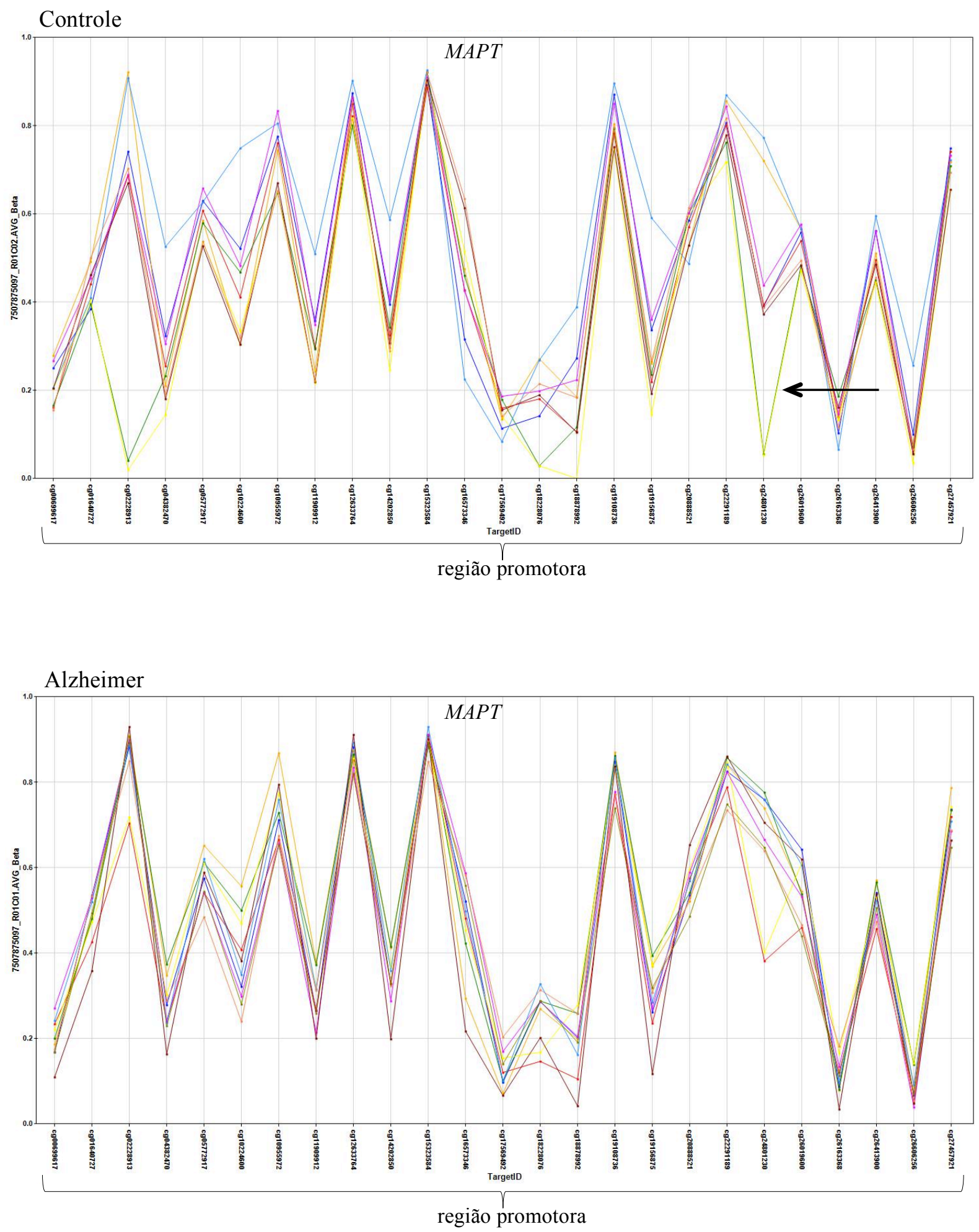

Figura 32. Distribuição dos níveis de metilação ao longo de alguns sítios CpG do gene $M A P T$. Cada linha representa um indivíduo e cada ponto equivale a um sítio $\mathrm{CpG}$ com seu respectivo valor de Beta, ordenados de acordo com suas posições genômicas. A seta indica o loci diferencialmente metilado observado em nossa casuística. Por ser um gene grande, o qual possui uma cobertura grande de $\mathrm{CpG}$, selecionamos alguns sítios $\mathrm{CpG}$ upstream e downstream para melhor visualização do resultado. Imagem extraída do programa computacional Genome Studio. 

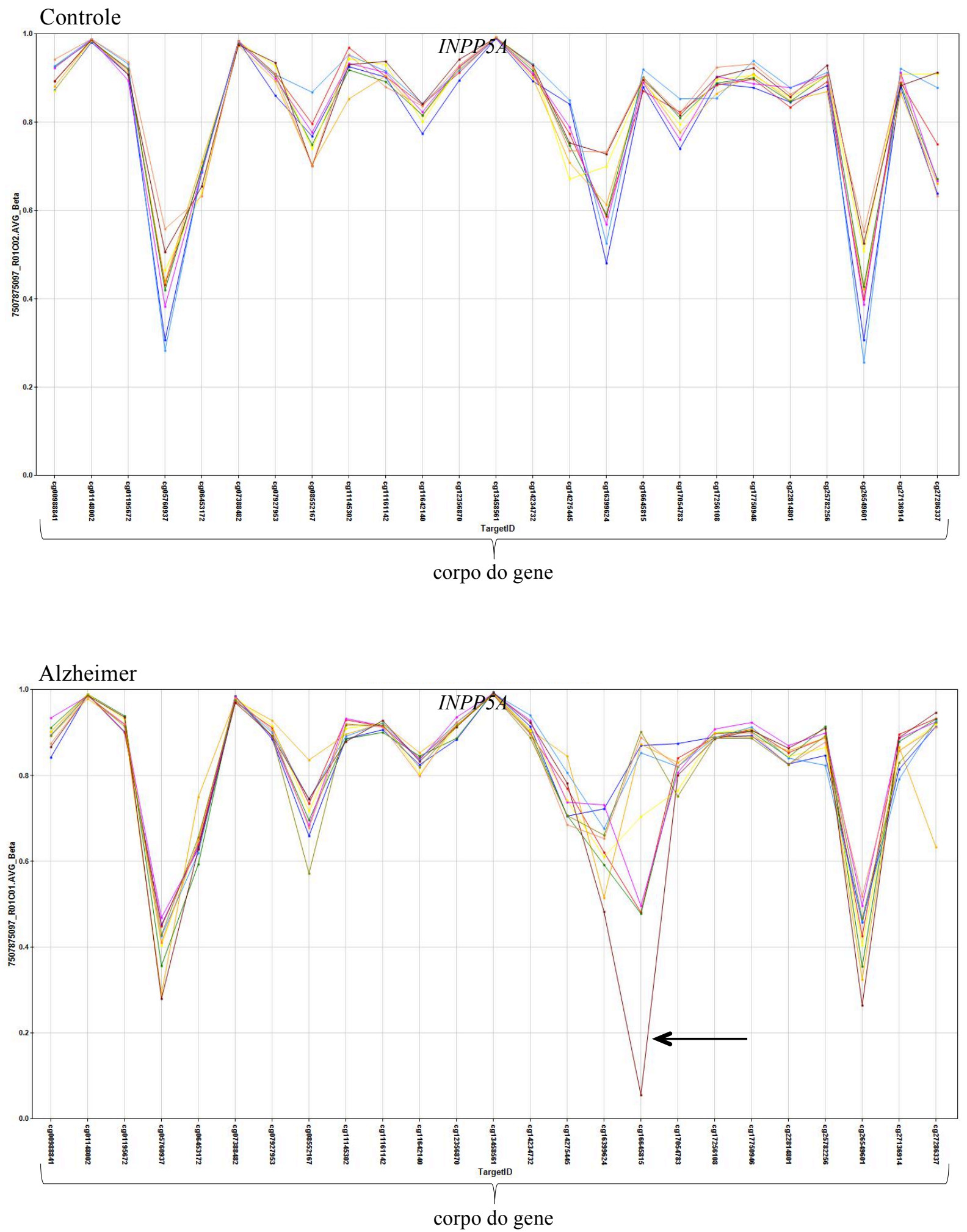

Figura 33. Distribuição dos níveis de metilação ao longo de todos os sítios CpG do gene INPP5A. Cada linha representa um indivíduo e cada ponto equivale a um sítio $\mathrm{CpG}$ com seu respectivo valor de Beta, ordenados de acordo com suas posições genômicas. A seta indica o loci diferencialmente metilado observado em nossa casuística. Por ser um gene grande, o qual possui uma cobertura grande de $\mathrm{CpG}$, selecionamos alguns sítios $\mathrm{CpG}$ upstream e downstream para melhor visualização do resultado. Imagem extraída do programa computacional Genome Studio. 

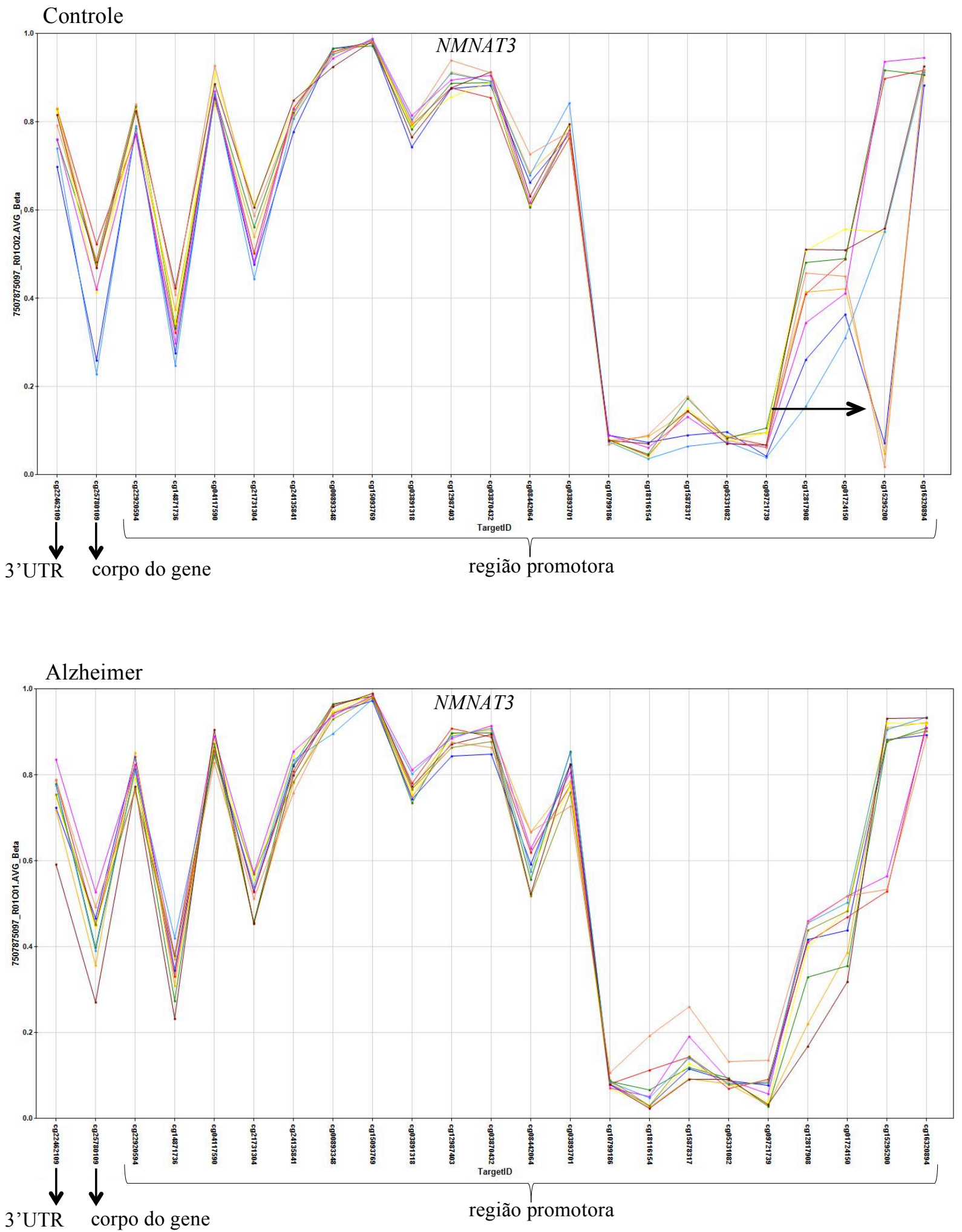

Figura 34. Distribuição dos níveis de metilação ao longo de todos os sítios CpG do gene NMNAT3. Cada linha representa um indivíduo e cada ponto equivale a um sítio $\mathrm{CpG}$ com seu respectivo valor de Beta, ordenados de acordo com suas posições genômicas. A seta indica o loci diferencialmente metilado observado em nossa casuística. Imagem extraída do programa computacional Genome Studio. 
V. DISCUSSÃO 


\section{DISCUSSÃO}

Este trabalho teve como principal objetivo investigar a contribuição de alguns fatores genéticos e epigenéticos que podem colaborar para a patogênese da DA, em particular de dois aspectos: variações no número de cópias de segmentos de DNA e alterações no padrão de metilação na doença. Em relação aos nossos dados sobre desequilíbrios genômicos, a análise estatística dos resultados globais de array-CGH revelou um aumento significativo no número total de CNVs por indivíduo no grupo controle quando comparado ao grupo DA. Os dados da literatura são controversos no que se refere a essa questão: enquanto alguns trabalhos reportam um excesso no número total de CNVs na DA (Heinzen et al., 2010; Swaminathan et al., 2011; Swaminathan et al., 2012c), o estudo de associação que teve a maior casuística já estudada não detectou nenhuma diferença entre casos e controles (Chapman et al., 2013). No entanto, nenhum trabalho teve achado semelhante ao nosso, isto é, um número maior de CNVs em controles do que no grupo DA. Ademais, em nossa avaliação, o tamanho das deleções raras se mostrou estaticamente maior no grupo controle, contrariando alguns GWAS que demonstram o oposto (Heinzen et al., 2010; Swaminathan et al., 2011; Swaminathan et al., 2012c). Esses achados inesperados precisariam ser replicados em uma amostragem maior para que pudessemos inferir se as diferenças observadas entre os dois grupos é de fato relevante para a DA. Contudo, dentre os 42 desequilíbrios genômicos raros encontrados em nosso grupo DA, ao menos 6 possuem conteúdo gênico especialmente interessantes para o fenótipo investigado.

Duas microduplicações raras, presentes em dois indivíduos distintos de nossa casuística, compreendem genes que codificam diferentes subunidades do mesmo tipo de canal de $\mathrm{Ca}^{2+}$ dependente de voltagem, o tipo L (CCDV-L). A duplicação em 3p21.1 ( $\left.\sim 665 \mathrm{~Kb}\right)$ abrange, entre outros genes, CACNA1D e CACNA2D3 e a duplicação em 3p21.31 ( 300 Kb) $C A C N A 2 D 2$. Os CCDV-L são constituídos por 5 subunidades: $\alpha-1, \alpha-2, \beta, \gamma$ e $\delta$ (Klugbauer et al., 2000). A subunidade $\alpha-1$ é transmembrana e representa o poro condutor do íon do canal (Catterall 2000). Existem diversos subtipos da subunidade $\alpha-1$, o subtipo $\alpha_{1 \mathrm{D}}$ é codificado pelo gene $C A C N A 1 D$ e expresso preferencialmente no cérebro. Já os subtipos $\alpha_{1 \mathrm{~A}}, \alpha_{1 \mathrm{~B}}, \alpha_{1 \mathrm{C}}$, $\alpha_{1 \mathrm{E}}, \alpha_{1 \mathrm{~F}}$ fazem parte de outros tipos de canais de cálcio e além de serem expressos no cérebro também podem ser encontrados nos rins, coração, pulmão, músculo liso e retina (Takahashi e Catterall 1987). As subunidades $\beta, \gamma$ e $\delta$ exercem funções de regulação de ativação e desativação dos canais. Em especial, a $\alpha-2 \delta$, que pode ser codificada por $C A C N A 2 D 3$ ou 
CACNA2D2, aumenta a amplitude das correntes de $\mathrm{Ca}^{2+}$ e regula a cinética de ativação e inativação do canal, atuando como uma subunidade regulatória dos CCDV-L (Perez-Reyes et al., 1992).

A respeito da sua importância no sistema nervoso central, os CCDV-L são sabidamente elementos-chave de sinalização, permitindo mudanças no potencial de membrana, além de controlar um número grande de respostas dependentes de $\mathrm{Ca}^{2+}$. Essas respostas incluem, entre outras, a liberação de neurotransmissores, plasticidade neuronal e contração muscular (Burke e Barnes 2006). Estudos mostram que mudanças na homeostasia do $\mathrm{Ca}^{2+}$ são componentes notáveis no processo de envelhecimento cerebral, podendo afetar a cognição e aumentar a vulnerabilidade à doenças neurodegenerativas (Coon et al., 1999; Landfield 1987). Por conseguinte, um número crescente de evidências vem demonstrando que um dos principais eventos no processo de neurodegeneração é a incapacidade dos neurônios de regular adequadamente os níveis intracelulares $\mathrm{de} \mathrm{Ca}^{2+}$, podendo inclusive contribuir para impactar diretamente a patogenia da DA (Small 2009). Além disso, alguns trabalhos sugerem que fatores genéticos podem desempenhar um papel importante na desregulação da homeostasia do $\mathrm{Ca}^{2+}$ na DA. Dreses-Werringloer e colaboradores mostram que a expressão da variante polimórfica do gene CALHM1 ( $\mathrm{Ca}^{2+}$ homeostasis modulator-1), a qual foi significantemente associada à indivíduos com DA, aumenta os níveis de $\mathrm{A} \beta$ por reduzir a concentração citosólica de $\mathrm{Ca}^{2+}$ (Dreses-Werringloer et al., 2008). Ademais, mutações nos genes PSEN1 e PSEN2, responsáveis por causar a forma familial da doença, provocam um aumento da liberação de $\mathrm{Ca}^{2+}$ dos canais 1,4,5-trifosfato inositol (IP3), e podem alterar o metabolismo de fosfatidilinositol 4.5-bifosfato (PIP2), importante regulador do fluxo do íon nas células e que influencia diretamente os níveis de $\mathrm{A} \beta$ (Tu et al., 2006).

Logo, podemos supor que o rompimento dos genes CACNA1D, CACNA2D3 e CACNA2D2, causado pelas microduplicações observadas em nossa casuísta, poderiam causar uma disfunção dos componentes dos CCDV-L e provocar uma desregulação da homeostasia do $\mathrm{Ca}^{2+}$, podendo inclusive colaborar para impactar diretamente a patogenia da DA. Embora haja estudos na literatura associando mudanças no número de cópias de genes importantes na sinalização do $\mathrm{Ca}^{2+}$ com doenças do neurodesenvolvimento, como autismo e esclerose amiotrófica lateral (Lee et al., 2012; Rosenfeld et al., 2010; Wain et al., 2009), nosso resultado é o primeiro a reportar desequilíbrios genômicos em genes que codificam importantes subunidades dos CCDV-L e relacioná-los com a forma multifatorial da DA (resultados submetidos para publicação na revista BMC Research Note, Anexo I). 
Com relação às outras $4 \mathrm{CNVs}$ raras, consideradas relevantes em nosso estudo, 3 delas envolvem genes que participam de diferentes processos inflamatórios. As microduplicações em 22q13.2 ( 90 Kb) e 10p15.1-p14 ( 462 Kb) rompem NFAM1 e PRKCQ, respectivamente, e a microdeleção em 12q22 ( 129 Kb) o gene $C R A D D$. Vale destacar que na microduplicação em 3p21.1, discutida anteriormente, além dos genes CACNA1D e CACNA2D3, mais um gene envolvido com resposta inflamatória foi observado alterado em nosso grupo de estudo e que pertence à essa $\mathrm{CNV}, \mathrm{o} I L 17 R B$.

A proteína codificada por IL17RB é um receptor de citocina, ao qual se liga especificamente as interleucinas 17B e 17E (Rickel et al., 2008). Já $P R K C Q$ codifica uma proteína que é um dos membros da família das proteínas quinases $\mathrm{C}$, que pode ser ativada por segundos mensageiros como o $\mathrm{Ca}^{2+}$ e diacilglicerol (Zhang et al., 2013). Porém, ambos os produtos dos dois genes são responsáveis por mediar a ativação do fator de transcrição NF$\kappa \mathrm{B}$, o qual claramente possui um papel importante no sistema nervoso central (Mattson e

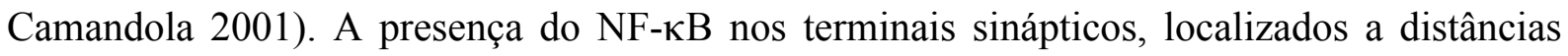
consideráveis do corpo celular neuronal, e a capacidade que este tem de ser ativado

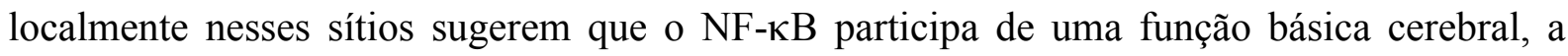
modulação sináptica (O'Neill e Kaltschmidt 1997). Outras evidências apontando o NF-אB como um notável participante da regulação da função sináptica vêm de estudos demonstrando que a estimulação dos receptores de glutamato e a despolarização de membrana estimulam a ativação desse fator de transcrição em neurônios, o qual também pode ser ativado juntamente com a potencialização crônica da transmissão sináptica, um processo que acredita-se ser um mecanismo celular de aprendizado e memória (Meberg et al., 1996). Além disso, já foi mostrado que seu bloqueio altera a plasticidade sináptica (Albensi e Mattson 2000).

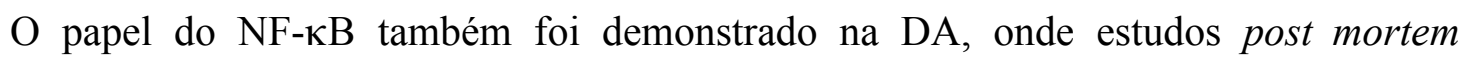
utilizando tecido cerebral revelaram um aumento da atividade do NF- $\kappa B$ nas células neuronais e gliais envolvidas no processo neurodegenerativo (O'Neill e Kaltschmidt 1997).

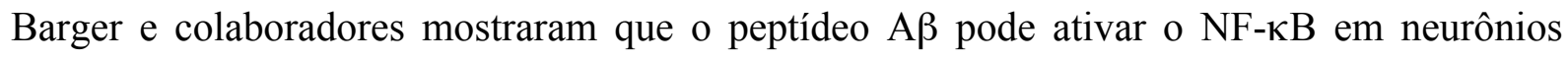
mantidos em cultura, e que essa ativação pode resultar num efeito neuroprotetor, uma vez que o fator de necrose tumoral $\alpha$ (TNF- $\alpha$ ) pode proteger os neurônios contra a apoptose induzida

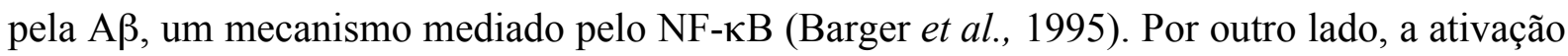
do NF-кB nas células da glia, em especial as microglias (células que representam o sistema imune inato do cérebro), resulta na produção e liberação de uma grande variedade de mediadores pro-inflamatórios incluindo interleucinas, radicais livres, óxido nítrico e também 
o TNF- $\alpha$ (Tilstra et al., 2011). A hipótese de que reações inflamatórias mediadas pela

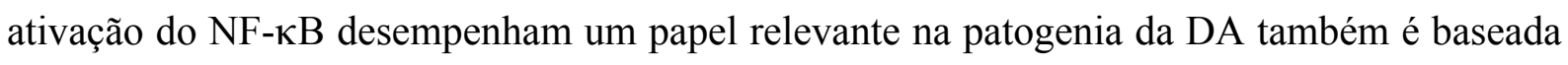
na observação de que injeções crônicas de lipopolisacarídeo (um ativador clássico do NF-кB) na cavidade peritoneal de ratos acelera a formação de placas de $\mathrm{A} \beta$ no cérebro desses animais (Malek et al., 2007).

Em relação ao genes $N F A M 1$ e $C R A D D$, o primeiro codifica uma proteína que atua como receptor de membrana do tipo I, responsável por ativar a região promotora de citocinas como o TNF- $\alpha$; já o segundo codifica uma proteína que contém um domínio de morte que induz apoptose e também interage com o TNF- $\alpha$. Assim como no caso do NF- $\mathrm{B}$, a importância do TNF- $\alpha$ na DA já foi demonstrada por diversos estudos (Heneka et al., 2010). Atualmente, essa e outras citocinas são usadas como biomarcadores inflamatórios para auxiliar no diagnóstico precoce da DA, os níveis de TNF- $\alpha$ são medidos no fluido cerebroespinal e apresentam-se elevados em pacientes com DA quando comparados à indivíduos normais (Hall et al., 2013). O TNF- $\alpha$ é liberado pela microglia em resposta à uma série de fatores, incluindo o peptídeo $A \beta 42$. Seu efeito neurotóxico envolve a indução de morte neuronal, o aumento da produção da proteína APP e o processamento da mesma com resultante formação do peptídeo A $\beta 42$ (Streit 2004). Logo, o próprio peptídeo A $\beta 42$ gera uma grande reação inflamatória, particularmente no depósito das placas senis, induzindo as células da glia a expressarem diversas citocinas pro-inflamatórias, entre elas o TNF- $\alpha$, em um círculo vicioso, o que contribui para a progressão patológica da DA (Streit et al., 2004). No que se refere a indução de morte neuronal causada pelo TNF- $\alpha$, esta pode ocorrer via a liberação de grandes quantidades do neurotransmissor glutamato pelas microglias, causando uma excitoneurotoxicidade e consequentemente dano neuronal (Rubio-Perez e Morillas-Ruiz 2012).

Devido a inúmeras evidências obtidas in vitro e in vivo (citadas anteriormente) de que processos inflamatórios desempenham um papel chave na patogenia da DA, alguns estudos caso-controle reportaram polimorfismos em genes que codificam diferentes citocinas como possíveis fatores de risco genético para a DA (Licastro et al., 2003; Lio et al., 2006; Wang et $a l ., 2005)$. Wan e colaboradores sugerem inclusive que um background genético propenso à inflamação pode contribuir para o risco individual de desenvolver a DA (Wan et al., 2008). No entanto, nenhum trabalho da literatura havia documentado CNVs relacionadas com inflamação em indivíduos com DA. Nossos dados são os primeiros a associar desequilíbrios 
genômicos raros em genes participantes de processos inflamatórios e relacioná-los à forma multifatorial da DA.

A última CNV rara com conteúdo gênico relevante para a DA identificada em nossa casuística é uma microdeleção em 7q22.2 ( 145 Kb) que rompe o gene NAMPT. Esse gene codifica a enzima nicotinamida fosforibosiltransferase (NAMPT), uma das enzimas passolimitante da via de biossíntese da nicotinamida adenina dinucleotídeo (NAD), uma molécula considerada muito importante em diversos processos biológicos como metabolismo, stress oxidativo e envelhecimento (Imai 2011). Estudos recentes demonstraram claramente a conexão funcional entre a via de biossíntese da NAD mediada pela NAMPT e as sirtuinas, em especial a SIRT1 (Haigis e Sinclair 2010). Sirtuinas são proteínas altamente conservadas evolutivamente, caracterizadas por um motivo estrutural central necessário para a atividade desacetilase dependente de NAD. Em mamíferos, existem 7 sirtuinas (SIRT1 a SIRT7) com funções e localizações celulares muito divergentes entre si (Imai e Guarente 2010). Evidências sugerem que SIRT1 desempenha um papel importante em retardar mudanças patofisiológicas associadas à idade e prevenir doenças relacionadas com o envelhecimento como o diabetes tipo 2, câncer e a DA (Imai 2009). Em 2010, Donmez e colaboradores mostraram que a SIRT1 previne dois aspectos patológicos críticos na DA: a deposição das placas de A $\beta$ e a tauopatia. SIRT1 diminui a produção do peptídeo A $\beta$ pela desacetilação do receptor do ácido retinóico $\beta$ e dessa forma aumenta a expressão de ADAM10, o principal componente da $\alpha$-secretase (Donmez et al., 2010). SIRT1 também promove a degradação da proteína Tau fosforilada pela sua desacetilação, prevenindo a neurodegeneração mediada por essa proteína (Min et al., 2010). Além do mais, SIRT1 regula a plasticidade sináptica e memória, podendo ser um novo alvo para uma possível intervenção contra doenças cognitivas associadas à idade (Gao et al., 2010; Michan et al., 2010).

Levando em consideração essas informações na literatura, podemos supor que um rompimento do gene $N A M P T$ poderia causar uma alteração dos níveis de expressão gênica dessa enzima e contribuir para uma desregulação da via de biossíntese da NAD, o que impactaria diretamente a ação da SIRT1. A SIRT1 estando downregulated promove uma diminuição da desacetilação do receptor do ácido retinóico $\beta$ com consequente redução da expressão de ADAM10 e aumento da formação do peptídeo A $\beta$ (Donmez et al., 2010). Nosso dado é o primeiro a demonstrar um desequilíbrio genômico no gene NAMPT e relacionar essa alteração a um fenótipo de DA (resultado aceito para publicação na revista Journal of Genetics, Anexo II). 
Concluindo o estudo sobre CNVs na DA, um último resultado interessante foi observado ao realizarmos a análise estatística dos dados de array-CGH. Ao averiguar o número total de desequilíbrios genômicos detectados em sangue versus cerebelo, constatamos um aumento significativo no número de $\mathrm{CNVs}$ em cerebelo, independentemente das amostras pertencerem ao grupo controle ou DA. Confirmamos esse resultado em amostras pareadas de 19 indivíduos controle, ou seja, examinamos amostras de sangue e cerebelo dos mesmos sujeitos e obervamos a mesma diferença no número total de CNVs. Esses resultados podem evidenciar tanto, a presença de uma maior instabilidade genômica quanto uma seleção menos estringente contra desequilíbrios genômicos no cérebro humano resultando em maior frequência de CNVs. Alguns autores já reportaram a presença de variação genômica causada por aneuploidia no cérebro humano em desenvolvimento, em uma taxa estimada de 30-35\% (Pack et al., 2005; Yurov et al., 2007). Embora ainda não seja possível determinar a taxa exata de aneuploidia no cérebro humano adulto, devido a uma série de limitações técnicas, vários estudos apresentam evidências de que existe uma população significante de células aneuploides em nosso cérebro. Rehen e colaboradores, utilizando a técnica de FISH, investigaram a presença de aneussomia do cromossomo 21 em células do córtex frontal e observaram uma frequência maior de monossomia ao invés de trissomia (Rehen et al., 2005). Há autores também que usando a mesma técnica analisaram vários cromossomos simultaneamente (Iourov et al., 2006; Pack et al., 2005; Yurov et al., 2005). Estes estudos citados documentaram em média uma frequência de 0.1 a $0.8 \%$ de células aneuploides. Porém, é importante ressaltar que todos esses trabalhos sofrem críticas em relação ao número amostral. Uma análise ainda que de um número grande de células estudadas individualmente representa uma porcentagem insignificante dentre as quase 1 trilhão de células presentes no cérebro humano, o que torna muito difícil estabelecer em que porcentagem ocorre aneuploidia em nosso cérebro. Além disso, existe uma dificuldade em distinguir precisamente os diferentes tipos celulares que compõem o cérebro durante uma análise de FISH (Bushman e Chun 2013).

Recentemente, McConnel e colaboradores demonstraram pela primeira vez, através do sequenciamento de célula única, uma alta variabilidade de CNVs em neurônios derivados de células-tronco pluripotentes induzidas (hiPSC) e também em neurônios do córtex frontal obtidos post mortem de humanos (McConnell et al., 2013). Utilizando uma metodologia mais simples, nós também observamos uma instabilidade genômica causada por desequilíbrios genômicos em nossas amostras de cerebelo. No entanto, apesar das semelhanças entre os resultados, existem diferenças quantitativas e qualitativas entre a nossa análise, baseada em 
um pool de DNA, e o método usado por McConnell. O sequenciamento do genoma de uma célula permite a detecção de mutações únicas, representativas dessa célula, enquanto que uma análise de array-CGH baseada em um pool de DNA determina uma média da estrutura genômica da amostra de um dado tecido. Logo, apesar dos autores reportarem abundância de CNVs em células neuronais humanas isoladas, nossos dados sugerem que as CNVs podem ocorrer de forma clonal em neurônios. Para determinar quão extensos são esses clones neuronais e como se distribuem no sistema nervoso, a análise de múltiplas amostras de regiões distintas do encéfalo dos mesmos indivíduos seria necessária. O mapeamento desse mosaico deve permitir inferir quando e onde, no desenvolvimento, as alterações somáticas ocorreram. É possível que algumas linhagens neuronais adquiram variabilidade genômica durante o desenvolvimento, ou que neurônios tornem-se propensos a eventos mutacionais em grande escala devido a danos generalizados no DNA. Os mecanismos responsáveis pela geração dessa variabilidade genômica neuronal também fazem parte de um tema meramente especulativo. McConnel e colaboradores sugerem que a alta atividade de retrotransposons durante a neurogênese pode contribuir para um aumento na prevalência de CNVs nos genomas neuronais, uma vez que já foi mostrado que retrotransposons podem causar deleções e outros rearranjos em células humanas (McConnell et al., 2013). Porém, outros mecanismos como quebra de fita dupla no DNA e a presença de microDNAs no núcleo merecem ser estudados uma vez que há evidências recentes apontando para a existência desses mecanismos em neurônios (Maeda et al., 2004; Suberbielle et al., 2013).

Em relação ao outro aspecto investigado neste projeto - o estudo do padrão de metilação do DNA na DA - nossa análise de metilação diferencial identificou a presença de 54 loci diferencialmente metilados nos indivíduos com DA em relação ao grupo controle. A maioria desses sítios CpG apresentam-se hipermetilados, sugerindo uma possível repressão da transcrição gênica. Além disso, dos 54, somente 3 loci estão associados a genes sem SNPs no sítio de detecção; porém, os genes correspondentes à esses 3 loci (ADAMTS19, CUX1 e FAM66A) nunca foram associados à DA e, baseando-se em suas funções, não os consideramos relevantes para o fenótipo investigado. Por outro lado, 3 genes que apresentam loci diferencialmente metilados mas que estão associados a SNPs destacam-se como especialmente interessantes em nossa casuística. $M A P T$, que codifica a proteína Tau associada a microtúbulo, reconhecidamente possui um papel importante na DA; já foi demonstrado que mutações nesse gene elevam a produção do RNAm, causando um aumento da proteína Tau e consequentemente formação dos emaranhados neurofibrilares (Rademakers et al., 2004). Os outros dois genes, INPP5A e NMNAT3, participam da homeostasia do $\mathrm{Ca}^{2+}$ intracelular e na 
via de biossíntese da NAD, respectivamente. O primeiro é responsável por codificar InsP3 5fosfatase, uma proteína que mobiliza $\mathrm{Ca}^{2+}$ intracelular e atua como segundo mensageiro, mediando diversas respostas celulares (Mitchell et al., 1996); e o segundo codifica a enzima nicotinamida mononucleotídeo adeniltransferase 3 (NMNAT3), que converte nicotinamida mononucleotídeo em NAD, sendo um elemento determinante na via de biossíntese dessa molécula (Zhai et al., 2009). A importância da homeostasia do $\mathrm{Ca}^{2+}$ intracelular e da NAD na DA já foi discutida anteriormente quando analisamos os desequilíbrios genômicos correspondentes ao genes CACNA1D, CACNA2D2, CACNA2D3 e NAMPT. É importante ressaltar que níveis alterados de metilação dos sítios $\mathrm{CpG}$ identificados e associados a SNPs não constituem uma alteração epigenética condicionada pelo fenótipo, mas, sim, uma mudança no nível de metilação ocasionada por uma variação na sequência de DNA. Ainda é preciso validar esses SNPs e investigar sua frequência em uma casuística maior de indivíduos com DA a fim de avaliar a relevância desses sítios CpGs identificados para o fenótipo.

Devido ao investimento no desenvolvimento de tecnologias baseada em array e sequenciamento, o que possibilita um estudo em larga escala de inúmeros sítios CpG simultaneamente, a metilação do DNA é, sem dúvida, a marca epigenética mais estudada atualmente. Os estudos sobre o papel da variação de metilação do DNA nas doenças complexas começaram a ser explorados inicialmente no contexto do câncer. Em geral, demonstrou-se que o desenvolvimento tumoral está associado com um ganho de metilação nas ilhas CpG e um remodelamento epigenético nas sequências repetitivas, ou seja, uma desmetilação nos DNA satélite (Baylin e Jones 2011; Ting et al., 2011). No entanto, ainda são poucos os trabalhos na literatura investigando o padrão global de metilação em outras doenças comuns, como a DA. O manuscrito de Bakulski e colaboradores, utilizando a plataforma $27 \mathrm{~K}$ da Illumina, é o primeiro e único estudo caso-controle a associar loci diferencialmente metilados à DA. Em uma casuística modesta (6 controles e 6 DA), os autores identificaram 25 sítios CpG diferencialmente metilados, com destaque para o gene TMEM59, o qual participa da modificação pós-traducional da proteína precursora beta amiloide. Porém, a magnitude da diferença de metilação entre casos e controle foi relativamente pequena, 7.3\%. Ademais, não houve uma investigação sobre uma possível associação dos sítios CpG diferencialmente metilados a SNPs (Bakulski et al., 2012).

Talvez o fator mais preponderante para a escassez de trabalhos seja a complexidade da análise dos dados de metilação. É importante considerar que a metilação do DNA, ou qualquer outra variação epigenética, pode ser causal ou surgir como consequência de um processo patológico. A distinção entre causa e consequência não é um processo simples, 
porém, crucial na elucidação da variação associada à doença e seu potencial uso em termos de diagnóstico ou terapêutica. Usualmente, existem três maneiras pelas quais uma variação pode ocorrer antes de uma patologia (Rakyan et al., 2011). Em primeiro lugar, a variação pode ser herdada e, consequentemente, estar presente em todos os tecidos, incluindo a linhagem germinativa (herança epigenética transgeracional). Em segundo lugar, uma variação pode ocorrer estocasticamente e estar presente em todo o soma, se ela ocorrer no início do desenvolvimento, ou pode ser limitada a algum tecido, se acontecer durante a vida adulta. Por fim, existe a possibilidade de uma variação epigenética ser induzida por um fator ambiental, que pode estar relacionado com o estilo de vida do indivíduo, como dieta ou fumo (Rakyan et al., 2011). No caso da DA, é muito difícil determinar causalidade devido a uma série de dificuldades inerentes em relação a fato de se trabalhar com esse tipo de doença. Sendo a metilação do DNA altamente tecido específica, a menos que inventem métodos não invasivos para se obter amostras de DNA do encéfalo, a escolha mais óbvia para se trabalhar com qualquer tipo de doença neurodegenerativa é utilizando amostras de tecido encefálico obtidos post mortem. No entanto, sem que haja uma comparação anterior e posterior ao surgimento do processo patológico fica complicado definir se as variações de metilação observadas são causa ou consequência da doença. Além disso, não só para o encéfalo mas para qualquer outro tipo de tecido, composto por diferentes tipos celulares, ainda é um desafio identificar e determinar se as alterações de metilação são restritas a um dado tipo celular (Laird 2010).

Um outro aspecto relevante a levar em consideração são os diferentes tipos de variação na metilação do DNA que podem ocorrer. Os dois tipos mais estudados nos estudos de associação epigenômicos são as alterações que existem um único sítio $\mathrm{CpG}$, conhecidas como posições de metilação variável (Methylation Variable Positions - MVP), equivalentes a um SNP epigenético; e as regiões diferencialmente metiladas (Differentially Methylated Regions - DMRs) (Barros e Offenbacher 2009; Ohgane et al., 2008). As DMRs podem compreender vários sítios $\mathrm{CpG}$ adjacentes e variar consideravelmente em comprimento (Frigola et al., 2006). Até recentemente, MVPs e DMRs foram investigadas principalmente nas regiões promotoras e nas ilhas $\mathrm{CpG}$; no entanto, está se tornando cada vez mais claro que a metilação do DNA é um processo dinâmico, mesmo fora dessa regiões (Robertson 2005). Um estudo recente demonstrou que DMRs específicas ao câncer de cólon ocorrem principalmente nas regiões adjacentes às ilhas CpG, em Shore e Shelf(Irizarry et al., 2009). Em nossos resultados nós também observamos que a variação de metilação não acontece preferencialmente nas ilhas $\mathrm{CpG}$ mas, sim, em Shore, Shelf e Open Sea. Ainda em relação às DMRs, esse tipo de variação tem se mostrado bastante relevante em aumentar o poder 
estatístico de uma análise de metilação para identificar loci significativos e posteriormente estudar seu significado biológico (Bock 2012). Convencionalmente, é comum comparar os níveis de metilação de cada citosina entre as amostras dos grupos de estudo, através de um teste $t$ por exemplo, e em seguida aplicar um teste múltiplo de correção. Porém, devido ao número grande de $\mathrm{CpG}$ a serem comparadas, apenas os sítios que apresentarem as maiores diferenças de metilação vão permanecer estatisticamente significantes após vários testes de correção. O resultado é muitas vezes uma taxa de falso-negativo elevada, especialmente quando o número de amostras e o tamanho de efeito são pequenos, além de que a grande maioria dos CpGs testados não apresentará variação no padrão de metilação entre os grupos (Bock 2012). Logo, ao restringir regiões de tal modo que $\mathrm{CpG}$ vizinhos com diferenças de metilação semelhantes sejam analisados em conjunto aumentamos a chance de resultados mais significativos. Futuramente, pretendemos continuar a análise dos nossos dados de metilação na DA em busca de DMRs selecionadas por regiões genômicas candidatas, como região promotora, ilhas $\mathrm{CpG}$ ou áreas adjacentes. Para tanto, em colaboração com um bioinformata, testaremos diferentes pipelines que já foram validadas e estão disponíveis na literatura. 


\section{CONCLUSÕES}




\section{CONCLUSÕES}

O modelo de investigação usado nesse projeto para o estudo de desequilíbrios genômicos na DA, ou seja, a busca por variantes genômicas raras, selecionadas por tamanho e conteúdo gênico, em indivíduos com grau moderado a profundo da doença, representa um atalho na identificação de genes ou segmentos genômicos importantes. Enquanto os grandes estudos de associação utilizam variantes para apontar loci possivelmente relevantes, o conteúdo gênico de CNVs raras e de maior tamanho potencialmente representam os loci relevantes, já que podem resultar em alteração da expressão gênica e impactar diretamente o fenótipo. Em nosso trabalho, identificamos $6 \mathrm{CNVs}$ raras com conteúdo gênico especialmente interessante para o fenótipo investigado. Embora nenhuma CNV rara tenha se apresentado como recorrente em nosso grupo de estudo, dois sujeitos distintos de nossa casuística apresentaram microduplicações em genes que codificam diferentes subunidades do mesmo tipo de canal de $\mathrm{Ca}^{2+}$ dependente de voltagem, o tipo L. Apesar de mudanças no número de cópias de genes de $\mathrm{Ca}^{2+}$ terem sido previamente associadas a doenças do neurodesenvolvimento, este estudo apresenta as primeiras evidências da associação de desequilíbrios genômicos em genes reconhecidamente importantes para a sinalização celular do $\mathrm{Ca}^{2+}$ com a forma multifatorial da DA. O possível envolvimento do metabolismo do $\mathrm{Ca}^{2+}$ na etiologia na DA também foi reforçado por nossos achados sobre o padrão de metilação do DNA na DA. O gene INPP5A que possui um papel importante na homeostasia intracelular do $\mathrm{Ca}^{2+}$ apresenta um sítio $\mathrm{CpG}$ diferenciamente metilado nos indivíduos com DA. Mesmo considerando que esse resultado possa estar refletindo a presença subjacente de um SNP, nosso dado aponta mais uma vez para uma variação na sequência do DNA de outro gene relevante na sinalização do $\mathrm{Ca}^{2+}$. É importante ressaltar também que tanto através dos estudos de CNVs quanto do padrão de metilação do DNA na DA nós observamos também dois genes (NAMPT e NMNAT3) com padrão alterado que participam da via de biossíntese da NAD, uma molécula fundamental em diversos processos biológicos, inclusive no envelhecimento. Nossos resultados sugerem, portanto, que os desequilíbrios genômicos raros com conteúdo gênico relevante descritos nesse estudo, mesmo não sendo recorrentes, possam ter contribuído para o risco individual dos sujeitos investigados em desenvolver a DA. Acreditamos que os achados descritos nesse projeto possam estimular estudos funcionais futuros e eventualmente confirmar o papel desses genes alterados por microdeleções ou microduplicações na patogenia da DA; ou até mesmo no futuro contribuir como anotações relevantes para uma medicina personalizada e auxiliar no diagnóstico da DA. 
Ainda em relação à nossa investigação sobre o padrão de metilação do DNA na DA, embora seja crescente o interesse em explorar variações epigenéticas que possam influenciar o desenvolvimento de doenças complexas, a análise dos dados de metilação é complexa. A busca por um número limitado de regiões contendo sítios diferenciamente metilados têm se mostrado uma alternativa interessante para aumentar o poder estatístico da análise e extrair um significado biológico para os dados gerados. Logo, continuaremos nosso estudo investigando DMRs selecionadas por regiões genômicas candidatas, como região promotora, ilhas $\mathrm{CpG}$ ou áreas adjacentes, e testaremos diferentes pipelines que já foram validadas e estão disponíveis na literatura. 
VII. REFERÊNCIAS BIBLIOGRÁFICAS 


\section{REFERÊNCIAS BIBLIOGRÁFICAS}

Albensi BC, Mattson MP. Evidence for the involvement of TNF and NF-kappaB in hippocampal synaptic plasticity. Synapse, 2000, 35(2): 151-159.

Albers CA, Paul DS, Schulze H, Freson K, Stephens JC, Smethurst PA, Jolley JD, Cvejic A, Kostadima M, Bertone P, Breuning MH, Debili N, Deloukas P, Favier R, Fiedler J, Hobbs CM, Huang N, Hurles ME, Kiddle G, Krapels I, Nurden P, Ruivenkamp CA, Sambrook JG, Smith K, Stemple DL, Strauss G, Thys C, van Geet C, Newbury-Ecob R, Ouwehand WH, Ghevaert C. Compound inheritance of a low-frequency regulatory SNP and a rare null mutation in exon-junction complex subunit RBM8A causes TAR syndrome. Nat Genet, 2012, 44(4): 435-439, S431-432.

Almeida P, Wickerhauser H. O Critério ABA/ABIPEME - em Busca de Uma Atualização. Um estudo e uma proposta submetidos à ABA e à ABIPEME. São Paulo, Editora da Associação Brasileira dos Institutos de Pesquisa de Mercado, 1991.

Arlt MF, Wilson TE, Glover TW. Replication stress and mechanisms of CNV formation. Curr Opin Genet Dev, 2012, 22(3): 204-210.

Avramopoulos D. Genetics of Alzheimer's disease: recent advances. Genome Med, 2009, 1(3): 34 .

Bakulski KM, Dolinoy DC, Sartor MA, Paulson HL, Konen JR, Lieberman AP, Albin RL, Hu H, Rozek LS. Genome-wide DNA methylation differences between late-onset Alzheimer's disease and cognitively normal controls in human frontal cortex. J Alzheimers Dis, 2012, 29(3): 571-588.

Barger SW, Horster D, Furukawa K, Goodman Y, Krieglstein J, Mattson MP. Tumor necrosis factors alpha and beta protect neurons against amyloid beta-peptide toxicity: evidence for involvement of a kappa B-binding factor and attenuation of peroxide and $\mathrm{Ca} 2+$ accumulation. Proc Natl Acad Sci U S A, 1995, 92(20): 9328-9332. 
Barros SP, Offenbacher S. Epigenetics: connecting environment and genotype to phenotype and disease. J Dent Res, 2009, 88(5): 400-408.

Baylin SB, Jones PA. A decade of exploring the cancer epigenome - biological and translational implications. Nat Rev Cancer, 2011, 11(10): 726-734.

Bergem AL, Engedal K, Kringlen E. The role of heredity in late-onset Alzheimer disease and vascular dementia. A twin study. Arch Gen Psychiatry, 1997, 54(3): 264-270.

Bergman Y, Cedar H. DNA methylation dynamics in health and disease. Nat Struct Mol Biol, 2013, 20(3): 274-281.

Berrios GE. Alzheimer's disease: a conceptual history. International Journal of Geriatric Psychiatry, 1990, 5: 355-365.

Berrios GE. The history of Alzheimer's disease. 2005.

Blennow K, de Leon MJ, Zetterberg H. Alzheimer's disease. Lancet, 2006, 368(9533): 387403.

Blessed G, Tomlinson BE, Roth $\mathrm{M}$. The association between quantitative measures of dementia and of senile change in the cerebral grey matter of elderly subjects. Br J Psychiatry, 1968, 114(512): 797-811.

Bock C. Analysing and interpreting DNA methylation data. Nat Rev Genet, 2012, 13(10): 705-719.

Braak H, Braak E. Neuropathological stageing of Alzheimer-related changes. Acta Neuropathol, 1991, 82(4): 239-259.

Brouwers N, Van Cauwenberghe C, Engelborghs S, Lambert JC, Bettens K, Le Bastard N, Pasquier F, Montoya AG, Peeters K, Mattheijssens M, Vandenberghe R, Deyn PP, Cruts M, Amouyel P, Sleegers K, Van Broeckhoven C. Alzheimer risk associated with a copy number 
variation in the complement receptor 1 increasing $\mathrm{C} 3 \mathrm{~b} / \mathrm{C} 4 \mathrm{~b}$ binding sites. Mol Psychiatry, 2012, 17(2): 223-233.

Burke SN, Barnes CA. Neural plasticity in the ageing brain. Nature reviews. Neuroscience, 2006, 7(1): 30-40.

Bushman DM, Chun J. The genomically mosaic brain: aneuploidy and more in neural diversity and disease. Semin Cell Dev Biol, 2013, 24(4): 357-369.

Catterall WA. Structure and regulation of voltage-gated Ca2+ channels. Annual review of cell and developmental biology, 2000, 16: 521-555.

Chapman J, Rees E, Harold D, Ivanov D, Gerrish A, Sims R, Hollingworth P, Stretton A, Holmans P, Owen MJ, O'Donovan MC, Williams J, Kirov G. A genome-wide study shows a limited contribution of rare copy number variants to Alzheimer's disease risk. Hum Mol Genet, 2013, 22(4): 816-824.

Chodavarapu RK, Feng S, Bernatavichute YV, Chen PY, Stroud H, Yu Y, Hetzel JA, Kuo F, Kim J, Cokus SJ, Casero D, Bernal M, Huijser P, Clark AT, Kramer U, Merchant SS, Zhang X, Jacobsen SE, Pellegrini M. Relationship between nucleosome positioning and DNA methylation. Nature, 2010, 466(7304): 388-392.

Chouliaras L, Mastroeni D, Delvaux E, Grover A, Kenis G, Hof PR, Steinbusch HW, Coleman PD, Rutten BP, van den Hove DL. Consistent decrease in global DNA methylation and hydroxymethylation in the hippocampus of Alzheimer's disease patients. Neurobiol Aging, 2013, 34(9): 2091-2099.

Consortium TWTCC. Genome-wide association study of 14,000 cases of seven common diseases and 3,000 shared controls. Nature, 2007, 447(7145): 661-678.

Coon AL, Wallace DR, Mactutus CF, Booze RM. L-type calcium channels in the hippocampus and cerebellum of Alzheimer's disease brain tissue. Neurobiol Aging, 1999, 20(6): 597-603. 
Corder EH, Saunders AM, Strittmatter WJ, Schmechel DE, Gaskell PC, Small GW, Roses AD, Haines JL, Pericak-Vance MA. Gene dose of apolipoprotein E type 4 allele and the risk of Alzheimer's disease in late onset families. Science, 1993, 261(5123): 921-923.

Cummings JL, Mega M, Gray K, Rosenberg-Thompson S, Carusi DA, Gornbein J. The Neuropsychiatric Inventory: comprehensive assessment of psychopathology in dementia. Neurology, 1994, 44(12): 2308-2314.

Davies L, Wolska B, Hilbich C, Multhaup G, Martins R, Simms G, Beyreuther K, Masters CL. A4 amyloid protein deposition and the diagnosis of Alzheimer's disease: prevalence in aged brains determined by immunocytochemistry compared with conventional neuropathologic techniques. Neurology, 1988, 38(11): 1688-1693.

Donmez G, Wang D, Cohen DE, Guarente L. SIRT1 suppresses beta-amyloid production by activating the alpha-secretase gene ADAM10. Cell, 2010, 142(2): 320-332.

Drechsel DN, Hyman AA, Cobb MH, Kirschner MW. Modulation of the dynamic instability of tubulin assembly by the microtubule-associated protein tau. Mol Biol Cell, 1992, 3(10): 1141-1154.

Dreses-Werringloer U, Lambert JC, Vingtdeux V, Zhao H, Vais H, Siebert A, Jain A, Koppel J, Rovelet-Lecrux A, Hannequin D, Pasquier F, Galimberti D, Scarpini E, Mann D, Lendon C, Campion D, Amouyel P, Davies P, Foskett JK, Campagne F, Marambaud P. A polymorphism in CALHM1 influences Ca2+ homeostasis, Abeta levels, and Alzheimer's disease risk. Cell, 2008, 133(7): 1149-1161.

Duyckaerts C, Delatour B, Potier MC. Classification and basic pathology of Alzheimer disease. Acta Neuropathol, 2009, 118(1): 5-36.

Farrer LA, Cupples LA, Haines JL, Hyman B, Kukull WA, Mayeux R, Myers RH, PericakVance MA, Risch N, van Duijn CM. Effects of age, sex, and ethnicity on the association between apolipoprotein E genotype and Alzheimer disease. A meta-analysis. APOE and Alzheimer Disease Meta Analysis Consortium. JAMA, 1997, 278(16): 1349-1356. 
Ferri CP, Prince M, Brayne C, Brodaty H, Fratiglioni L, Ganguli M, Hall K, Hasegawa K, Hendrie H, Huang Y, Jorm A, Mathers C, Menezes PR, Rimmer E, Scazufca M. Global prevalence of dementia: a Delphi consensus study. Lancet, 2005, 366(9503): 2112-2117.

Feuk L, Carson AR, Scherer SW. Structural variation in the human genome. Nat Rev Genet, 2006, 7(2): 85-97.

Frigola J, Song J, Stirzaker C, Hinshelwood RA, Peinado MA, Clark SJ. Epigenetic remodeling in colorectal cancer results in coordinate gene suppression across an entire chromosome band. Nat Genet, 2006, 38(5): 540-549.

Gao J, Wang WY, Mao YW, Graff J, Guan JS, Pan L, Mak G, Kim D, Su SC, Tsai LH. A novel pathway regulates memory and plasticity via SIRT1 and miR-134. Nature, 2010, 466(7310): 1105-1109.

Gatz M, Pedersen NL, Berg S, Johansson B, Johansson K, Mortimer JA, Posner SF, Viitanen M, Winblad B, Ahlbom A. Heritability for Alzheimer's disease: the study of dementia in Swedish twins. J Gerontol A Biol Sci Med Sci, 1997, 52(2): M117-125.

Gatz M, Reynolds CA, Fratiglioni L, Johansson B, Mortimer JA, Berg S, Fiske A, Pedersen NL. Role of genes and environments for explaining Alzheimer disease. Arch Gen Psychiatry, 2006, 63(2): 168-174.

Gauthier S, Reisberg B, Zaudig M, Petersen RC, Ritchie K, Broich K, Belleville S, Brodaty H, Bennett D, Chertkow H, Cummings JL, de Leon M, Feldman H, Ganguli M, Hampel H, Scheltens P, Tierney MC, Whitehouse P, Winblad B. Mild cognitive impairment. Lancet, 2006, 367(9518): 1262-1270.

Gibney ER, Nolan CM. Epigenetics and gene expression. Heredity (Edinb), 2010, 105(1): 413.

Goate A, Chartier-Harlin MC, Mullan M, Brown J, Crawford F, Fidani L, Giuffra L, Haynes A, Irving N, James L, et al. Segregation of a missense mutation in the amyloid precursor protein gene with familial Alzheimer's disease. Nature, 1991, 349(6311): 704-706. 
Graeber MB. Alois Alzheimer (1864-1915). 2003.

Grinberg LT, Ferretti RE, Farfel JM, Leite R, Pasqualucci CA, Rosemberg S, Nitrini R, Saldiva PH, Filho WJ. Brain bank of the Brazilian aging brain study group - a milestone reached and more than 1,600 collected brains. Cell and tissue banking, 2007, 8(2): 151-162.

Gu W, Zhang F, Lupski JR. Mechanisms for human genomic rearrangements. Pathogenetics, 2008, 1(1): 4 .

Haigis MC, Sinclair DA. Mammalian sirtuins: biological insights and disease relevance. Annual review of pathology, 2010, 5: 253-295.

Hall JR, Wiechmann AR, Johnson LA, Edwards M, Barber RC, Winter AS, Singh M, O'Bryant SE. Biomarkers of vascular risk, systemic inflammation, and microvascular pathology and neuropsychiatric symptoms in Alzheimer's disease. J Alzheimers Dis, 2013, 35(2): 363-371.

Hardy JA, Higgins GA. Alzheimer's disease: the amyloid cascade hypothesis. Science, 1992, 256(5054): 184-185.

Harold D, Abraham R, Hollingworth P, Sims R, Gerrish A, Hamshere ML, Pahwa JS, Moskvina V, Dowzell K, Williams A, Jones N, Thomas C, Stretton A, Morgan AR, Lovestone S, Powell J, Proitsi P, Lupton MK, Brayne C, Rubinsztein DC, Gill M, Lawlor B, Lynch A, Morgan K, Brown KS, Passmore PA, Craig D, McGuinness B, Todd S, Holmes C, Mann D, Smith AD, Love S, Kehoe PG, Hardy J, Mead S, Fox N, Rossor M, Collinge J, Maier W, Jessen F, Schurmann B, Heun R, van den Bussche H, Heuser I, Kornhuber J, Wiltfang J, Dichgans M, Frolich L, Hampel H, Hull M, Rujescu D, Goate AM, Kauwe JS, Cruchaga C, Nowotny P, Morris JC, Mayo K, Sleegers K, Bettens K, Engelborghs S, De Deyn PP, Van Broeckhoven C, Livingston G, Bass NJ, Gurling H, McQuillin A, Gwilliam R, Deloukas P, Al-Chalabi A, Shaw CE, Tsolaki M, Singleton AB, Guerreiro R, Muhleisen TW, Nothen MM, Moebus S, Jockel KH, Klopp N, Wichmann HE, Carrasquillo MM, Pankratz VS, Younkin SG, Holmans PA, O'Donovan M, Owen MJ, Williams J. Genome-wide association study identifies variants at CLU and PICALM associated with Alzheimer's disease. Nat Genet, 2009, 41(10): 1088-1093. 
Harvey RJ, Skelton-Robinson M, Rossor MN. The prevalence and causes of dementia in people under the age of 65 years. J Neurol Neurosurg Psychiatry, 2003, 74(9): 1206-1209.

Heinzen EL, Need AC, Hayden KM, Chiba-Falek O, Roses AD, Strittmatter WJ, Burke JR, Hulette CM, Welsh-Bohmer KA, Goldstein DB. Genome-wide scan of copy number variation in late-onset Alzheimer's disease. J Alzheimers Dis, 2010, 19(1): 69-77.

Heneka MT, O'Banion MK, Terwel D, Kummer MP. Neuroinflammatory processes in Alzheimer's disease. Journal of neural transmission, 2010, 117(8): 919-947.

Henrichsen CN, Chaignat E, Reymond A. Copy number variants, diseases and gene expression. Hum Mol Genet, 2009, 18(R1): R1-8.

Hurles ME, Dermitzakis ET, Tyler-Smith C. The functional impact of structural variation in humans. Trends Genet, 2008, 24(5): 238-245.

Iafrate AJ, Feuk L, Rivera MN, Listewnik ML, Donahoe PK, Qi Y, Scherer SW, Lee C. Detection of large-scale variation in the human genome. Nat Genet, 2004, 36(9): 949-951.

Illingworth RS, Bird AP. CpG islands--'a rough guide'. FEBS Lett, 2009, 583(11): 17131720.

Illingworth RS, Gruenewald-Schneider U, Webb S, Kerr AR, James KD, Turner DJ, Smith C, Harrison DJ, Andrews R, Bird AP. Orphan CpG islands identify numerous conserved promoters in the mammalian genome. PLoS Genet, 2010, 6(9): e1001134.

Imai S. The NAD World: a new systemic regulatory network for metabolism and aging-Sirt1, systemic NAD biosynthesis, and their importance. Cell Biochem Biophys, 2009, 53(2): $65-74$.

Imai S. Dissecting systemic control of metabolism and aging in the NAD World: the importance of SIRT1 and NAMPT-mediated NAD biosynthesis. FEBS Lett, 2011, 585(11): $1657-1662$. 
Imai S, Guarente L. Ten years of NAD-dependent SIR2 family deacetylases: implications for metabolic diseases. Trends in pharmacological sciences, 2010, 31(5): 212-220.

Ionita-Laza I, Rogers AJ, Lange C, Raby BA, Lee C. Genetic association analysis of copynumber variation (CNV) in human disease pathogenesis. Genomics, 2009, 93(1): 22-26.

Iourov IY, Liehr T, Vorsanova SG, Kolotii AD, Yurov YB. Visualization of interphase chromosomes in postmitotic cells of the human brain by multicolour banding (MCB). Chromosome Res, 2006, 14(3): 223-229.

Iqbal K, Alonso Adel C, Chen S, Chohan MO, El-Akkad E, Gong CX, Khatoon S, Li B, Liu F, Rahman A, Tanimukai H, Grundke-Iqbal I. Tau pathology in Alzheimer disease and other tauopathies. Biochim Biophys Acta, 2005, 1739(2-3): 198-210.

Iraola-Guzman S, Estivill X, Rabionet R. DNA methylation in neurodegenerative disorders: a missing link between genome and environment? Clin Genet, 2011, 80(1): 1-14.

Irizarry RA, Ladd-Acosta C, Wen B, Wu Z, Montano C, Onyango P, Cui H, Gabo K, Rongione M, Webster M, Ji H, Potash JB, Sabunciyan S, Feinberg AP. The human colon cancer methylome shows similar hypo- and hypermethylation at conserved tissue-specific CpG island shores. Nat Genet, 2009, 41(2): 178-186.

Jones PA. Functions of DNA methylation: islands, start sites, gene bodies and beyond. Nat Rev Genet, 2012, 13(7): 484-492.

Jun G, Naj AC, Beecham GW, Wang LS, Buros J, Gallins PJ, Buxbaum JD, Ertekin-Taner N, Fallin MD, Friedland R, Inzelberg R, Kramer P, Rogaeva E, St George-Hyslop P, Cantwell LB, Dombroski BA, Saykin AJ, Reiman EM, Bennett DA, Morris JC, Lunetta KL, Martin ER, Montine TJ, Goate AM, Blacker D, Tsuang DW, Beekly D, Cupples LA, Hakonarson H, Kukull W, Foroud TM, Haines J, Mayeux R, Farrer LA, Pericak-Vance MA, Schellenberg GD. Meta-analysis confirms CR1, CLU, and PICALM as alzheimer disease risk loci and reveals interactions with APOE genotypes. Arch Neurol, 2010, 67(12): 1473-1484. 
Kacem S, Feil R. Chromatin mechanisms in genomic imprinting. Mamm Genome, 2009, 20(9-10): 544-556.

Kamboh MI, Demirci FY, Wang X, Minster RL, Carrasquillo MM, Pankratz VS, Younkin SG, Saykin AJ, Jun G, Baldwin C, Logue MW, Buros J, Farrer L, Pericak-Vance MA, Haines JL, Sweet RA, Ganguli M, Feingold E, Dekosky ST, Lopez OL, Barmada MM. Genome-wide association study of Alzheimer's disease. Transl Psychiatry, 2012, 2: e117.

Kamenetz F, Tomita T, Hsieh H, Seabrook G, Borchelt D, Iwatsubo T, Sisodia S, Malinow R. APP processing and synaptic function. Neuron, 2003, 37(6): 925-937.

Karran E, Mercken M, De Strooper B. The amyloid cascade hypothesis for Alzheimer's disease: an appraisal for the development of therapeutics. Nat Rev Drug Discov, 2011, 10(9): 698-712.

Katz S, Ford AB, Moskowitz RW. Studies of illness in the aged. The index of ADL: a standardized measure of biological and psychological function. $\boldsymbol{J A M A}, 1994,185$ : 914-919.

Klopocki E, Schulze H, Strauss G, Ott CE, Hall J, Trotier F, Fleischhauer S, Greenhalgh L, Newbury-Ecob RA, Neumann LM, Habenicht R, Konig R, Seemanova E, Megarbane A, Ropers HH, Ullmann R, Horn D, Mundlos S. Complex inheritance pattern resembling autosomal recessive inheritance involving a microdeletion in thrombocytopenia-absent radius syndrome. Am J Hum Genet, 2007, 80(2): 232-240.

Klugbauer N, Dai S, Specht V, Lacinova L, Marais E, Bohn G, Hofmann F. A family of gamma-like calcium channel subunits. FEBS Lett, 2000, 470(2): 189-197.

Klunemann HH, Fronhofer W, Wurster H, Fischer W, Ibach B, Klein HE. Alzheimer's second patient: Johann F. and his family. Ann Neurol, 2002, 52(4): 520-523.

Komura D, Shen F, Ishikawa S, Fitch KR, Chen W, Zhang J, Liu G, Ihara S, Nakamura H, Hurles ME, Lee C, Scherer SW, Jones KW, Shapero MH, Huang J, Aburatani H. Genomewide detection of human copy number variations using high-density DNA oligonucleotide arrays. Genome Res, 2006, 16(12): 1575-1584. 
Koolen DA, Sharp AJ, Hurst JA, Firth HV, Knight SJ, Goldenberg A, Saugier-Veber P, Pfundt R, Vissers LE, Destree A, Grisart B, Rooms L, Van der Aa N, Field M, Hackett A, Bell K, Nowaczyk MJ, Mancini GM, Poddighe PJ, Schwartz CE, Rossi E, De Gregori M, Antonacci-Fulton LL, McLellan MD, 2nd, Garrett JM, Wiechert MA, Miner TL, Crosby S, Ciccone R, Willatt L, Rauch A, Zenker M, Aradhya S, Manning MA, Strom TM, Wagenstaller J, Krepischi-Santos AC, Vianna-Morgante AM, Rosenberg C, Price SM, Stewart H, Shaw-Smith C, Brunner HG, Wilkie AO, Veltman JA, Zuffardi O, Eichler EE, de Vries BB. Clinical and molecular delineation of the 17q21.31 microdeletion syndrome. $\boldsymbol{J}$ Med Genet, 2008, 45(11): 710-720.

Laird PW. Principles and challenges of genomewide DNA methylation analysis. Nat Rev Genet, 2010, 11(3): 191-203.

Lambert JC, Heath S, Even G, Campion D, Sleegers K, Hiltunen M, Combarros O, Zelenika D, Bullido MJ, Tavernier B, Letenneur L, Bettens K, Berr C, Pasquier F, Fievet N, BarbergerGateau P, Engelborghs S, De Deyn P, Mateo I, Franck A, Helisalmi S, Porcellini E, Hanon O, de Pancorbo MM, Lendon C, Dufouil C, Jaillard C, Leveillard T, Alvarez V, Bosco P, Mancuso M, Panza F, Nacmias B, Bossu P, Piccardi P, Annoni G, Seripa D, Galimberti D, Hannequin D, Licastro F, Soininen H, Ritchie K, Blanche H, Dartigues JF, Tzourio C, Gut I, Van Broeckhoven C, Alperovitch A, Lathrop M, Amouyel P. Genome-wide association study identifies variants at CLU and CR1 associated with Alzheimer's disease. Nat Genet, 2009, 41(10): 1094-1099.

Landfield PW. 'Increased calcium-current' hypothesis of brain aging. Neurobiol Aging, 1987, 8(4): 346-347.

Larsen F, Solheim J, Prydz H. A methylated CpG island 3' in the apolipoprotein-E gene does not repress its transcription. Hum Mol Genet, 1993, 2(6): 775-780.

Lawton MP, Brody EM. Assessment of older people: self-maintaining and instrumental activities of daily living. The Gerontologist, 1969, 9(3): 179-186.

Lee C, Iafrate AJ, Brothman AR. Copy number variations and clinical cytogenetic diagnosis of constitutional disorders. Nat Genet, 2007a, 39(7 Suppl): S48-54. 
Lee J, Ryu H. Epigenetic modification is linked to Alzheimer's disease: is it a maker or a marker? BMB Rep, 2010, 43(10): 649-655.

Lee JA, Carvalho CM, Lupski JR. A DNA replication mechanism for generating nonrecurrent rearrangements associated with genomic disorders. Cell, 2007b, 131(7): 1235-1247.

Lee KW, Woon PS, Teo YY, Sim K. Genome wide association studies (GWAS) and copy number variation (CNV) studies of the major psychoses: what have we learnt? Neurosci Biobehav Rev, 2012, 36(1): 556-571.

Lesnik Oberstein SA, Kriek M, White SJ, Kalf ME, Szuhai K, den Dunnen JT, Breuning MH, Hennekam RC. Peters Plus syndrome is caused by mutations in B3GALTL, a putative glycosyltransferase. Am J Hum Genet, 2006, 79(3): 562-566.

Licastro F, Grimaldi LM, Bonafe M, Martina C, Olivieri F, Cavallone L, Giovanietti S, Masliah E, Franceschi C. Interleukin-6 gene alleles affect the risk of Alzheimer's disease and levels of the cytokine in blood and brain. Neurobiol Aging, 2003, 24(7): 921-926.

Lio D, Annoni G, Licastro F, Crivello A, Forte GI, Scola L, Colonna-Romano G, Candore G, Arosio B, Galimberti L, Vergani C, Caruso C. Tumor necrosis factor-alpha $-308 \mathrm{~A} / \mathrm{G}$ polymorphism is associated with age at onset of Alzheimer's disease. Mech Ageing Dev, 2006, 127(6): 567-571.

Liu P, Carvalho CM, Hastings PJ, Lupski JR. Mechanisms for recurrent and complex human genomic rearrangements. Curr Opin Genet Dev, 2012, 22(3): 211-220.

Lu H, Liu X, Deng Y, Qing H. DNA methylation, a hand behind neurodegenerative diseases. Front Aging Neurosci, 2013, 5: 85.

Maeda T, Chijiiwa Y, Tsuji H, Sakoda S, Tani K, Suzuki T. Somatic DNA recombination yielding circular DNA and deletion of a genomic region in embryonic brain. Biochem Biophys Res Commun, 2004, 319(4): 1117-1123. 
Malek R, Borowicz KK, Jargiello M, Czuczwar SJ. Role of nuclear factor kappaB in the central nervous system. Pharmacol Rep, 2007, 59(1): 25-33.

Mastroeni D, Grover A, Delvaux E, Whiteside C, Coleman PD, Rogers J. Epigenetic changes in Alzheimer's disease: decrements in DNA methylation. Neurobiol Aging, 2010, 31(12): 2025-2037.

Mastroeni D, McKee A, Grover A, Rogers J, Coleman PD. Epigenetic differences in cortical neurons from a pair of monozygotic twins discordant for Alzheimer's disease. PLoS One, 2009, 4(8): e6617.

Mattson MP, Camandola S. NF-kappaB in neuronal plasticity and neurodegenerative disorders. The Journal of clinical investigation, 2001, 107(3): 247-254.

Maunakea AK, Nagarajan RP, Bilenky M, Ballinger TJ, D'Souza C, Fouse SD, Johnson BE, Hong C, Nielsen C, Zhao Y, Turecki G, Delaney A, Varhol R, Thiessen N, Shchors K, Heine VM, Rowitch DH, Xing X, Fiore C, Schillebeeckx M, Jones SJ, Haussler D, Marra MA, Hirst M, Wang T, Costello JF. Conserved role of intragenic DNA methylation in regulating alternative promoters. Nature, 2010, 466(7303): 253-257.

Maurer K, Volk S, Gerbaldo H. Auguste D and Alzheimer's disease. Lancet, 1997, 349(9064): 1546-1549.

Mayeux R. Epidemiology of neurodegeneration. Annu Rev Neurosci, 2003, 26: 81-104.

Mayeux R, Stern Y. Epidemiology of Alzheimer disease. Cold Spring Harb Perspect Med, $2012,2(8)$

McConnell MJ, Lindberg MR, Brennand KJ, Piper JC, Voet T, Cowing-Zitron C, Shumilina S, Lasken RS, Vermeesch JR, Hall IM, Gage FH. Mosaic copy number variation in human neurons. Science, 2013, 342(6158): 632-637. 
McKeel DW, Jr., Price JL, Miller JP, Grant EA, Xiong C, Berg L, Morris JC. Neuropathologic criteria for diagnosing Alzheimer disease in persons with pure dementia of Alzheimer type. J Neuropathol Exp Neurol, 2004, 63(10): 1028-1037.

McMenemey WH, Worster-Drought C, Flind J, Williams HG. Familial Presenile Dementia: Report of Case with Clinical and Pathological Features of Alzheimer's Disease. $\boldsymbol{J}$ Neurol Psychiatry, 1939, 2(4): 293-302.

Meberg PJ, Kinney WR, Valcourt EG, Routtenberg A. Gene expression of the transcription factor NF-kappa B in hippocampus: regulation by synaptic activity. Brain research. Molecular brain research, 1996, 38(2): 179-190.

Meyer MR, Tschanz JT, Norton MC, Welsh-Bohmer KA, Steffens DC, Wyse BW, Breitner JC. APOE genotype predicts when--not whether--one is predisposed to develop Alzheimer disease. Nat Genet, 1998, 19(4): 321-322.

Michan S, Li Y, Chou MM, Parrella E, Ge H, Long JM, Allard JS, Lewis K, Miller M, Xu W, Mervis RF, Chen J, Guerin KI, Smith LE, McBurney MW, Sinclair DA, Baudry M, de Cabo R, Longo VD. SIRT1 is essential for normal cognitive function and synaptic plasticity. $\boldsymbol{J}$ Neurosci, 2010, 30(29): 9695-9707.

Miller SA, Dykes DD, Polesky HF. A simple salting out procedure for extracting DNA from human nucleated cells. Nucleic Acids Res, 1988, 16(3): 1215.

Min SW, Cho SH, Zhou Y, Schroeder S, Haroutunian V, Seeley WW, Huang EJ, Shen Y, Masliah E, Mukherjee C, Meyers D, Cole PA, Ott M, Gan L. Acetylation of tau inhibits its degradation and contributes to tauopathy. Neuron, 2010, 67(6): 953-966.

Mirra SS, Heyman A, McKeel D, Sumi SM, Crain BJ, Brownlee LM, Vogel FS, Hughes JP, van Belle G, Berg L. The Consortium to Establish a Registry for Alzheimer's Disease (CERAD). Part II. Standardization of the neuropathologic assessment of Alzheimer's disease. Neurology, 1991, 41(4): 479-486. 
Mitchell CA, Speed CJ, Nicholl J, Sutherland GR. Chromosomal mapping of the gene (INPP5A) encoding the 43-kDa membrane-associated inositol polyphosphate 5-phosphatase to 10q26.3 by fluorescence in situ hybridization. Genomics, 1996, 31(1): 139-140.

Moore JH, Williams SM. Epistasis and its implications for personal genetics. Am J Hum Genet, 2009, 85(3): 309-320.

Morris JC. The Clinical Dementia Rating (CDR): current version and scoring rules. Neurology, 1993, 43(11): 2412-2414.

Mortimer JA, Snowdon DA, Markesbery WR. Head circumference, education and risk of dementia: findings from the Nun Study. J Clin Exp Neuropsychol, 2003, 25(5): 671-679.

Newell-Price J, Clark AJ, King P. DNA methylation and silencing of gene expression. Trends Endocrinol Metab, 2000, 11(4): 142-148.

O'Brien C. Auguste D. and Alzheimer's disease. Science, 1996, 273(5271): 28.

O'Neill LA, Kaltschmidt C. NF-kappa B: a crucial transcription factor for glial and neuronal cell function. Trends in neurosciences, 1997, 20(6): 252-258.

Ohgane J, Yagi S, Shiota K. Epigenetics: the DNA methylation profile of tissue-dependent and differentially methylated regions in cells. Placenta, 2008, 29 Suppl A: S29-35.

Olgiati P, Politis AM, Papadimitriou GN, De Ronchi D, Serretti A. Genetics of late-onset Alzheimer's disease: update from the alzgene database and analysis of shared pathways. Int $\boldsymbol{J}$ Alzheimers Dis, 2011, 2011: 832379.

Ooi SK, Qiu C, Bernstein E, Li K, Jia D, Yang Z, Erdjument-Bromage H, Tempst P, Lin SP, Allis CD, Cheng X, Bestor TH. DNMT3L connects unmethylated lysine 4 of histone H3 to de novo methylation of DNA. Nature, 2007, 448(7154): 714-717.

Pack SD, Weil RJ, Vortmeyer AO, Zeng W, Li J, Okamoto H, Furuta M, Pak E, Lubensky IA, Oldfield EH, Zhuang Z. Individual adult human neurons display aneuploidy: detection by 
fluorescence in situ hybridization and single neuron PCR. Cell Cycle, 2005, 4(12): 17581760.

Perez-Reyes E, Castellano A, Kim HS, Bertrand P, Baggstrom E, Lacerda AE, Wei XY, Birnbaumer L. Cloning and expression of a cardiac/brain beta subunit of the L-type calcium channel. J Biol Chem, 1992, 267(3): 1792-1797.

Perl DP. Neuropathology of Alzheimer's disease. Mt Sinai J Med, 2010, 77(1): 32-42.

Petersen RC. Mild cognitive impairment as a diagnostic entity. J Intern Med, 2004, 256(3): 183-194.

Pimplikar SW. Reassessing the amyloid cascade hypothesis of Alzheimer's disease. Int $\boldsymbol{J}$ Biochem Cell Biol, 2009, 41(6): 1261-1268.

Poirier J, Davignon J, Bouthillier D, Kogan S, Bertrand P, Gauthier S. Apolipoprotein E polymorphism and Alzheimer's disease. Lancet, 1993, 342(8873): 697-699.

Portela A, Esteller M. Epigenetic modifications and human disease. Nat Biotechnol, 2010, 28(10): 1057-1068.

Price ME, Cotton AM, Lam LL, Farre P, Emberly E, Brown CJ, Robinson WP, Kobor MS. Additional annotation enhances potential for biologically-relevant analysis of the Illumina Infinium HumanMethylation450 BeadChip array. Epigenetics Chromatin, 2013, 6(1): 4.

Querfurth HW, LaFerla FM. Alzheimer's disease. N Engl J Med, 2010, 362(4): 329-344.

Rademakers R, Cruts M, van Broeckhoven C. The role of tau (MAPT) in frontotemporal dementia and related tauopathies. Hum Mutat, 2004, 24(4): 277-295.

Rakyan VK, Down TA, Balding DJ, Beck S. Epigenome-wide association studies for common human diseases. Nat Rev Genet, 2011, 12(8): 529-541. 
Ramirez-Bermudez J. Alzheimer's disease: critical notes on the history of a medical concept. Arch Med Res, 2012, 43(8): 595-599.

Rao JS, Keleshian VL, Klein S, Rapoport SI. Epigenetic modifications in frontal cortex from Alzheimer's disease and bipolar disorder patients. Transl Psychiatry, 2012, 2: e132.

Rehen SK, Yung YC, McCreight MP, Kaushal D, Yang AH, Almeida BS, Kingsbury MA, Cabral KM, McConnell MJ, Anliker B, Fontanoz M, Chun J. Constitutional aneuploidy in the normal human brain. $\boldsymbol{J}$ Neurosci, 2005, 25(9): 2176-2180.

Reik W, Lewis A. Co-evolution of X-chromosome inactivation and imprinting in mammals. Nat Rev Genet, 2005, 6(5): 403-410.

Reitz C. Alzheimer's disease and the amyloid cascade hypothesis: a critical review. Int J Alzheimers Dis, 2012, 2012: 369808.

Rickel EA, Siegel LA, Yoon BR, Rottman JB, Kugler DG, Swart DA, Anders PM, Tocker JE, Comeau MR, Budelsky AL. Identification of functional roles for both IL-17RB and IL-17RA in mediating IL-25-induced activities. Journal of immunology, 2008, 181(6): 4299-4310.

Roberts GW, Gentleman SM, Lynch A, Murray L, Landon M, Graham DI. Beta amyloid protein deposition in the brain after severe head injury: implications for the pathogenesis of Alzheimer's disease. J Neurol Neurosurg Psychiatry, 1994, 57(4): 419-425.

Robertson KD. DNA methylation and human disease. Nat Rev Genet, 2005, 6(8): 597-610.

Rosenfeld JA, Ballif BC, Torchia BS, Sahoo T, Ravnan JB, Schultz R, Lamb A, Bejjani BA, Shaffer LG. Copy number variations associated with autism spectrum disorders contribute to a spectrum of neurodevelopmental disorders. Genet Med, 2010, 12(11): 694-702.

Rubio-Perez JM, Morillas-Ruiz JM. A review: inflammatory process in Alzheimer's disease, role of cytokines. ScientificWorldJournal, 2012, 2012: 756357. 
Schmidl C, Klug M, Boeld TJ, Andreesen R, Hoffmann P, Edinger M, Rehli M. Lineagespecific DNA methylation in $\mathrm{T}$ cells correlates with histone methylation and enhancer activity. Genome Res, 2009, 19(7): 1165-1174.

Schwartz S, Meshorer E, Ast G. Chromatin organization marks exon-intron structure. Nat Struct Mol Biol, 2009, 16(9): 990-995.

Sebat J, Lakshmi B, Troge J, Alexander J, Young J, Lundin P, Maner S, Massa H, Walker M, Chi M, Navin N, Lucito R, Healy J, Hicks J, Ye K, Reiner A, Gilliam TC, Trask B, Patterson N, Zetterberg A, Wigler M. Large-scale copy number polymorphism in the human genome. Science, 2004, 305(5683): 525-528.

Selkoe DJ. Amyloid protein and Alzheimer's disease. Sci Am, 1991, 265(5): 68-71, 74-66, 78.

Sharp AJ, Cheng Z, Eichler EE. Structural variation of the human genome. Annu Rev Genomics Hum Genet, 2006, 7: 407-442.

Shaw-Smith C, Redon R, Rickman L, Rio M, Willatt L, Fiegler H, Firth H, Sanlaville D, Winter R, Colleaux L, Bobrow M, Carter NP. Microarray based comparative genomic hybridisation (array-CGH) detects submicroscopic chromosomal deletions and duplications in patients with learning disability/mental retardation and dysmorphic features. J Med Genet, 2004, 41(4): 241-248.

Sherrington R, Rogaev EI, Liang Y, Rogaeva EA, Levesque G, Ikeda M, Chi H, Lin C, Li G, Holman K, Tsuda T, Mar L, Foncin JF, Bruni AC, Montesi MP, Sorbi S, Rainero I, Pinessi L, Nee L, Chumakov I, Pollen D, Brookes A, Sanseau P, Polinsky RJ, Wasco W, Da Silva HA, Haines JL, Perkicak-Vance MA, Tanzi RE, Roses AD, Fraser PE, Rommens JM, St GeorgeHyslop PH. Cloning of a gene bearing missense mutations in early-onset familial Alzheimer's disease. Nature, 1995, 375(6534): 754-760.

Shukla S, Kavak E, Gregory M, Imashimizu M, Shutinoski B, Kashlev M, Oberdoerffer P, Sandberg R, Oberdoerffer S. CTCF-promoted RNA polymerase II pausing links DNA methylation to splicing. Nature, 2011, 479(7371): 74-79. 
Small DH. Dysregulation of calcium homeostasis in Alzheimer's disease. Neurochem Res, 2009, 34(10): 1824-1829.

Spitzer RL, Williams JB, Gibbon M, First MB. The Structured Clinical Interview for DSMIII-R (SCID). I: History, rationale, and description. Arch Gen Psychiatry, 1992, 49(8): 624629.

Stadler MB, Murr R, Burger L, Ivanek R, Lienert F, Scholer A, van Nimwegen E, Wirbelauer C, Oakeley EJ, Gaidatzis D, Tiwari VK, Schubeler D. DNA-binding factors shape the mouse methylome at distal regulatory regions. Nature, 2011, 480(7378): 490-495.

Stankiewicz P, Inoue K, Bi W, Walz K, Park SS, Kurotaki N, Shaw CJ, Fonseca P, Yan J, Lee JA, Khajavi M, Lupski JR. Genomic disorders: genome architecture results in susceptibility to DNA rearrangements causing common human traits. Cold Spring Harb Symp Quant Biol, 2003, 68: 445-454.

Stankiewicz P, Lupski JR. Structural variation in the human genome and its role in disease. Annu Rev Med, 2010, 61: 437-455.

Stern Y. Cognitive reserve in ageing and Alzheimer's disease. Lancet Neurol, 2012, 11(11): 1006-1012.

Streit WJ. Microglia and Alzheimer's disease pathogenesis. J Neurosci Res, 2004, 77(1): 1-8.

Streit WJ, Mrak RE, Griffin WS. Microglia and neuroinflammation: a pathological perspective. J Neuroinflammation, 2004, 1(1): 14.

Strittmatter WJ, Saunders AM, Schmechel D, Pericak-Vance M, Enghild J, Salvesen GS, Roses AD. Apolipoprotein E: high-avidity binding to beta-amyloid and increased frequency of type 4 allele in late-onset familial Alzheimer disease. Proc Natl Acad Sci U S A, 1993, 90(5): 1977-1981. 
Suberbielle E, Sanchez PE, Kravitz AV, Wang X, Ho K, Eilertson K, Devidze N, Kreitzer AC, Mucke L. Physiologic brain activity causes DNA double-strand breaks in neurons, with exacerbation by amyloid-beta. Nat Neurosci, 2013, 16(5): 613-621.

Subramaniam D, Thombre R, Dhar A, Anant S. DNA Methyltransferases: A Novel Target for Prevention and Therapy. Front Oncol, 2014, 4: 80.

Swaminathan S, Huentelman MJ, Corneveaux JJ, Myers AJ, Faber KM, Foroud T, Mayeux R, Shen L, Kim S, Turk M, Hardy J, Reiman EM, Saykin AJ. Analysis of copy number variation in Alzheimer's disease in a cohort of clinically characterized and neuropathologically verified individuals. PLoS One, 2012a, 7(12): e50640.

Swaminathan S, Kim S, Shen L, Risacher SL, Foroud T, Pankratz N, Potkin SG, Huentelman MJ, Craig DW, Weiner MW, Saykin AJ, The Alzheimer's Disease Neuroimaging Initiative A. Genomic Copy Number Analysis in Alzheimer's Disease and Mild Cognitive Impairment: An ADNI Study. Int J Alzheimers Dis, 2011, 2011: 729478.

Swaminathan S, Shen L, Kim S, Inlow M, West JD, Faber KM, Foroud T, Mayeux R, Saykin AJ. Analysis of Copy Number Variation in Alzheimer's Disease: the NIA-LOAD/NCRAD Family Study. Curr Alzheimer Res, 2012b.

Swaminathan S, Shen L, Kim S, Inlow M, West JD, Faber KM, Foroud T, Mayeux R, Saykin AJ. Analysis of copy number variation in Alzheimer's disease: the NIALOAD/ NCRAD Family Study. Curr Alzheimer Res, 2012c, 9(7): 801-814.

Takahashi M, Catterall WA. Identification of an alpha subunit of dihydropyridine-sensitive brain calcium channels. Science, 1987, 236(4797): 88-91.

Tanner C, Gilley D, Goetz C. A brief screening questionnaire for Parkinsonism. Ann Neurol, 1990, 28: 267-268.

Tanzi RE, Bertram L. Twenty years of the Alzheimer's disease amyloid hypothesis: a genetic perspective. Cell, 2005, 120(4): 545-555. 
Terry RD, Davies P. Dementia of the Alzheimer type. Annu Rev Neurosci, 1980, 3: 77-95.

Tilstra JS, Clauson CL, Niedernhofer LJ, Robbins PD. NF-kappaB in Aging and Disease. Aging Dis, 2011, 2(6): 449-465.

Ting DT, Lipson D, Paul S, Brannigan BW, Akhavanfard S, Coffman EJ, Contino G, Deshpande V, Iafrate AJ, Letovsky S, Rivera MN, Bardeesy N, Maheswaran S, Haber DA. Aberrant overexpression of satellite repeats in pancreatic and other epithelial cancers. Science, 2011, 331(6017): 593-596.

Tu H, Nelson O, Bezprozvanny A, Wang Z, Lee SF, Hao YH, Serneels L, De Strooper B, Yu G, Bezprozvanny I. Presenilins form ER Ca2+ leak channels, a function disrupted by familial Alzheimer's disease-linked mutations. Cell, 2006, 126(5): 981-993.

Ullmann R, Turner G, Kirchhoff M, Chen W, Tonge B, Rosenberg C, Field M, ViannaMorgante AM, Christie L, Krepischi-Santos AC, Banna L, Brereton AV, Hill A, Bisgaard AM, Muller I, Hultschig C, Erdogan F, Wieczorek G, Ropers HH. Array CGH identifies reciprocal 16p13.1 duplications and deletions that predispose to autism and/or mental retardation. Hum Mutat, 2007, 28(7): 674-682.

Van Es MA, Van den Berg LH. Alzheimer's disease beyond APOE. Nat Genet, 2009, 41(10): 1047-1048.

Wain LV, Pedroso I, Landers JE, Breen G, Shaw CE, Leigh PN, Brown RH, Tobin MD, AlChalabi A. The role of copy number variation in susceptibility to amyotrophic lateral sclerosis: genome-wide association study and comparison with published loci. PLoS One, 2009, 4(12): e8175.

Walsh DM, Selkoe DJ. A beta oligomers - a decade of discovery. J Neurochem, 2007, 101(5): 1172-1184.

Wan Y, Wang G, Chen SD. Genetic predisposition to inflammation: a new risk factor of Alzheimer's disease. Neurosci Bull, 2008, 24(5): 314-322. 
Wang WF, Liao YC, Wu SL, Tsai FJ, Lee CC, Hua CS. Association of interleukin-I beta and receptor antagonist gene polymorphisms with late onset Alzheimer's disease in Taiwan Chinese. Eur J Neurol, 2005, 12(8): 609-613.

Weber MM. Aloys Alzheimer, a coworker of Emil Kraepelin. J Psychiatr Res, 1997, 31(6): 635-643.

Williams K, Christensen J, Helin K. DNA methylation: TET proteins-guardians of CpG islands? EMBO Rep, 2012, 13(1): 28-35.

You JS, Kelly TK, De Carvalho DD, Taberlay PC, Liang G, Jones PA. OCT4 establishes and maintains nucleosome-depleted regions that provide additional layers of epigenetic regulation of its target genes. Proc Natl Acad Sci U S A, 2011, 108(35): 14497-14502.

Yurov YB, Iourov IY, Monakhov VV, Soloviev IV, Vostrikov VM, Vorsanova SG. The variation of aneuploidy frequency in the developing and adult human brain revealed by an interphase FISH study. J Histochem Cytochem, 2005, 53(3): 385-390.

Yurov YB, Iourov IY, Vorsanova SG, Liehr T, Kolotii AD, Kutsev SI, Pellestor F, Beresheva AK, Demidova IA, Kravets VS, Monakhov VV, Soloviev IV. Aneuploidy and confined chromosomal mosaicism in the developing human brain. PLoS One, 2007, 2(6): e558.

Zhai RG, Rizzi M, Garavaglia S. Nicotinamide/nicotinic acid mononucleotide adenylyltransferase, new insights into an ancient enzyme. Cell Mol Life Sci, 2009, 66(17): 2805-2818.

Zhang C. Natural compounds that modulate BACE1-processing of amyloid-beta precursor protein in Alzheimer's disease. Discov Med, 2012, 14(76): 189-197.

Zhang C, Saunders AJ. Therapeutic targeting of the alpha-secretase pathway to treat Alzheimer's disease. Discov Med, 2007, 7(39): 113-117.

Zhang EY, Kong KF, Altman A. The yin and yang of protein kinase C-theta (PKCtheta): a novel drug target for selective immunosuppression. Adv Pharmacol, 2013, 66: 267-312. 
Zhang F, Khajavi M, Connolly AM, Towne CF, Batish SD, Lupski JR. The DNA replication FoSTeS/MMBIR mechanism can generate genomic, genic and exonic complex rearrangements in humans. Nat Genet, 2009, 41(7): 849-853.

Zhang Y, McLaughlin R, Goodyer C, LeBlanc A. Selective cytotoxicity of intracellular amyloid beta peptide1-42 through p53 and Bax in cultured primary human neurons. $J$ Cell Biol, 2002, 156(3): 519-529.

Zhu X, Avila J, Perry G, Smith MA. Treating the lesions, not the disease. Am J Pathol, 2007, 170(5): 1457-1459.

Zilberman D, Coleman-Derr D, Ballinger T, Henikoff S. Histone H2A.Z and DNA methylation are mutually antagonistic chromatin marks. Nature, 2008, 456(7218): 125-129. 


\section{MATERIAL SUPLEMENTAR}


Tabela S1. Todos os 250 sítios CpG considerados diferencialmente metilados entre os grupos controle e Doença de Alzheimer sem nenhum critério de exclusão.

\begin{tabular}{|c|c|c|c|c|c|c|c|c|c|c|c|}
\hline ID & C.A & DA.A & DB & $\mathrm{Chr}$ & Genes & $\begin{array}{l}\text { Distribuição Genômica } \\
\text { funcional }\end{array}$ & DI Ilha & $\begin{array}{l}\text { Reg } \\
\text { Amp }\end{array}$ & CPG_SNP & Sondas inespecíficas & $\begin{array}{l}\text { Seq. } \\
\text { Rep }\end{array}$ \\
\hline $\operatorname{cg} 25450649$ & 0,63 & 0,84 & 0,22 & 2 & - & 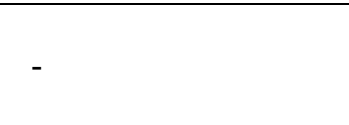 & N_Shore & SIM & $\begin{array}{l}\text { rs } 78738852 \\
\text { rs } 80026771\end{array}$ & $\begin{array}{r}\text { rs59010453,rs762504 } \\
06, \text { rs } 78738852 \\
\text { rs } 17159613, \text { rs } 800267\end{array}$ & 0 \\
\hline $\operatorname{cg} 10288111$ & 0,62 & 0,82 & 0,2 & 7 & IFRDI & TSS1500 & Open sea & SIM & rs7780160 & 71 & 0 \\
\hline $\operatorname{cg} 27395839$ & 0,62 & 0,87 & 0,25 & 15 & RORA;RORA;RORA;RORA & Body;Body;Body;Body & Open sea & SIM & rs35687658 & $\begin{array}{r}\mathrm{rs} 35687658 \\
\mathrm{rs} 13018658, \mathrm{rs} 582948\end{array}$ & 0 \\
\hline $\operatorname{cg} 23813394$ & 0,37 & 0,59 & 0,22 & 2 & $\begin{array}{l}\text { COL6A3;COL6A3;COL6A3 } \\
\text { SLC25A13;SLC25A13;SLC25A }\end{array}$ & Body;Body;Body & Open sea & SIM & rs6748910 & 64 & 0 \\
\hline $\operatorname{cg} 16792234$ & 0,46 & 0,25 & $-0,2$ & 7 & 13 & Body;Body;Body & Open sea & SIM & rs 12538111 & rs76870539 & 49 \\
\hline $\operatorname{cg} 16140565$ & 0,48 & 0,76 & 0,27 & 3 & FHIT;FHIT & Body;Body & Open sea & SIM & rs409484 & 0 & 0 \\
\hline $\operatorname{cg} 01553548$ & 0,37 & 0,59 & 0,22 & 4 & FRAS1;FRAS1 & Body;Body & Open sea & SIM & rs1385131 & rs1385131 & 0 \\
\hline $\operatorname{cg} 08238375$ & 0,34 & 0,63 & 0,29 & 5 & $M C C ; M C C$ & Body;Body & Open sea & SIM & rs4705795 & 0 & 0 \\
\hline $\operatorname{cg} 02819655$ & 0,42 & 0,67 & 0,25 & 2 & $P D E 11 A ; P D E 11 A$ & Body;Body & Open sea & SIM & rs 1405645 & 0 & 50 \\
\hline $\operatorname{cg} 00814218$ & 0,69 & 0,45 & $-0,23$ & 14 & SLC25A21;SLC25A21 & Body;Body & Open sea & SIM & rs 10131376 & rs 10483479 & 0 \\
\hline $\operatorname{cg} 10187601$ & 0,85 & 0,62 & $-0,23$ & 7 & $S T 7 ; S T 7$ & Body;Body & Open sea & SIM & rs 10270156 & 0 & 50 \\
\hline $\operatorname{cg} 01338296$ & 0,5 & 0,79 & 0,28 & 7 & $U B E 2 H ; U B E 2 H$ & Body;Body & Open sea & SIM & 0 & rs 12665878 & 9 \\
\hline $\operatorname{cg} 19471911$ & 0,41 & 0,63 & 0,22 & 11 & $Y A P 1 ; Y A P 1$ & Body;Body & Open sea & SIM & rs7107909 & 0 & 0 \\
\hline $\operatorname{cg} 02379549$ & 0,53 & 0,74 & 0,21 & 6 & C6orf89 & Body & Open sea & SIM & rs2272276 & 0 & 13 \\
\hline $\operatorname{cg} 24100293$ & 0,48 & 0,68 & 0,21 & 6 & FLJ22536 & Body & Open sea & SIM & rs9368372 & 0 & 20 \\
\hline $\operatorname{cg} 01006048$ & 0,86 & 0,64 & $-0,22$ & 10 & GPR158 & Body & Open sea & SIM & rs9663151 & rs495338 & 0 \\
\hline $\operatorname{cg} 08963013$ & 0,76 & 0,55 & $-0,2$ & 2 & LRRTM4 & Body & Open sea & SIM & rs 1446704 & rs62170867 & 0 \\
\hline cg27341708 & 0,37 & 0,57 & 0,2 & 4 & $M A M L 3$ & Body & Open sea & SIM & rs 11100449 & 0 & 0 \\
\hline cg26337497 & 0,68 & 0,45 & $-0,24$ & 3 & OSBPL10 & Body & Open sea & SIM & rs56221938 & 0 & 50 \\
\hline $\operatorname{cg} 16484499$ & 0,62 & 0,82 & 0,2 & 6 & $R E V 3 L$ & Body & Open sea & SIM & rs462432 & rs462432 & 0 \\
\hline $\operatorname{cg} 14548901$ & 0,48 & 0,72 & 0,24 & 2 & $R O C K 2$ & Body & Open sea & SIM & rs6707667 & 0 & 0 \\
\hline $\operatorname{cg} 21193926$ & 0,29 & 0,54 & 0,25 & 14 & $T G F B 3$ & Body & Open sea & SIM & rs 2284792 & rs3917162 & 0 \\
\hline $\operatorname{cg} 13078798$ & 0,25 & 0,47 & 0,22 & 1 & $T G F B R 3$ & Body & Open sea & SIM & rs 11165390 & 0 & 50 \\
\hline
\end{tabular}




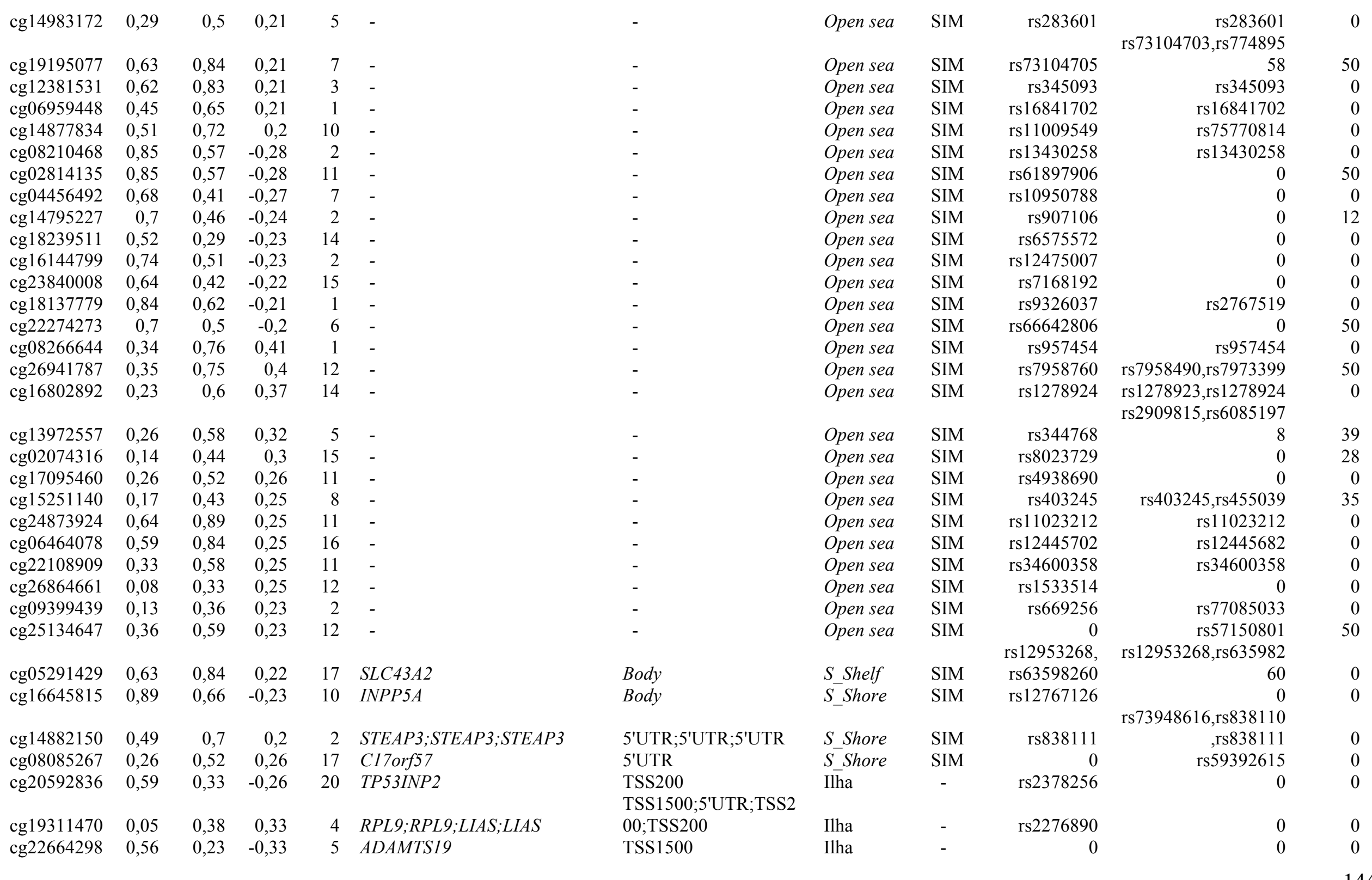




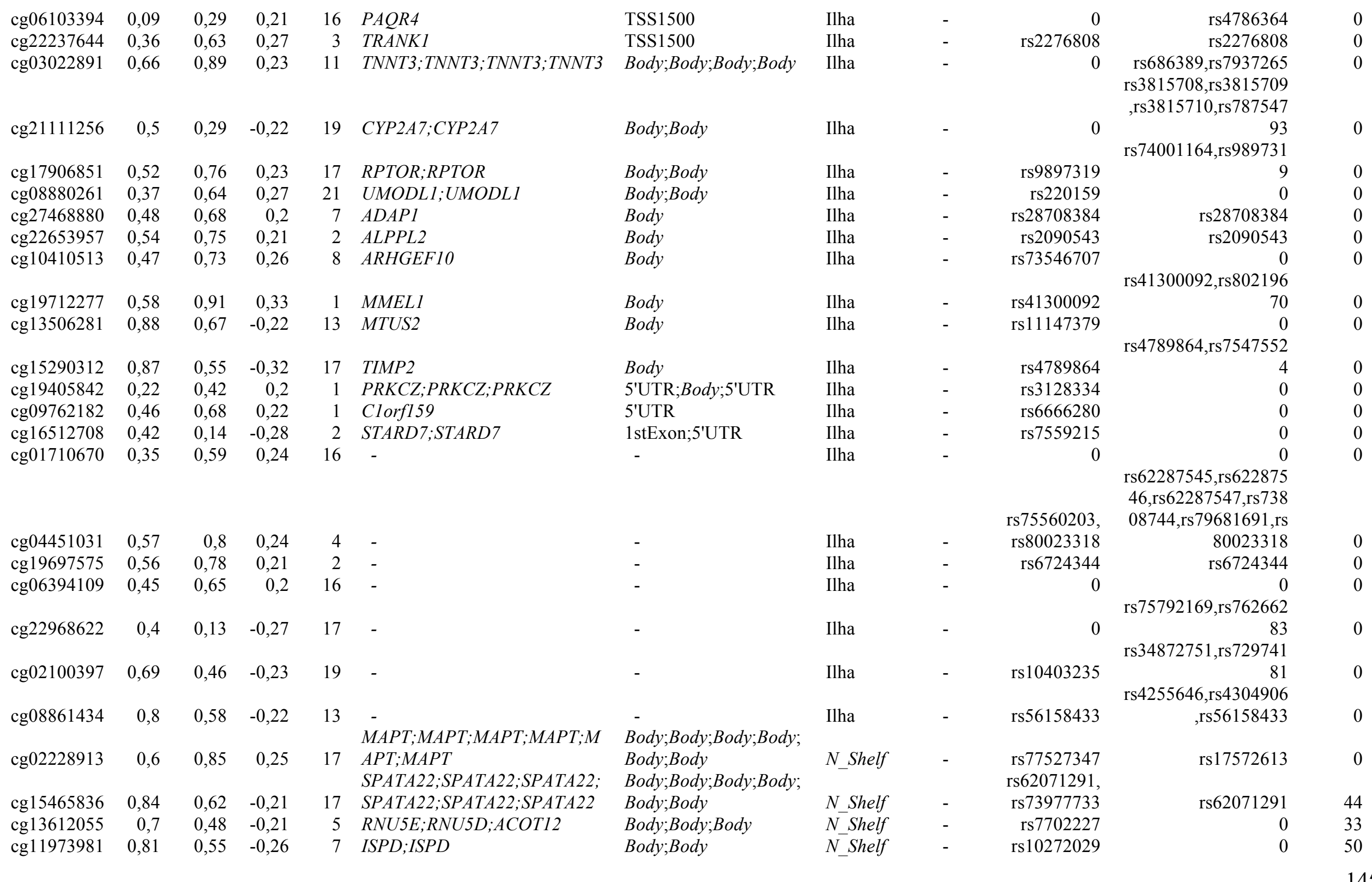




$\begin{array}{lrrrrl}\operatorname{cg} 06334689 & 0,27 & 0,52 & 0,25 & 16 & \text { DOC2A } \\ \operatorname{cg} 12515659 & 0,64 & 0,27 & -0,36 & 5 & \text { FAM134B } \\ \operatorname{cg} 22142142 & 0,74 & 0,48 & -0,26 & 15 & \text { GABARAPL3 } \\ \operatorname{cg} 19935756 & 0,63 & 0,4 & -0,23 & 4 & \text { GABRB1 } \\ \operatorname{cg} 26722972 & 0,83 & 0,61 & -0,22 & 16 & \text { SOLH } \\ \operatorname{cg} 19021236 & 0,81 & 0,61 & -0,21 & 22 & \text { MICAL3;MICAL3;MICAL3 } \\ & & & & & \\ \operatorname{cg} 26856631 & 0,12 & 0,54 & 0,42 & 7 & \text { LSM5;LSM5;LSM5;LSM5 } \\ \operatorname{cg} 25013753 & 0,38 & 0,7 & 0,33 & 10 & \text { ARHGAP22 } \\ \operatorname{cg} 22946888 & 0,55 & 0,77 & 0,22 & 5 & \text { THG1L } \\ \operatorname{cg} 13749548 & 0,28 & 0,57 & 0,28 & 14 & - \\ \operatorname{cg} 11222703 & 0,44 & 0,71 & 0,27 & 4 & - \\ \operatorname{cg} 14638919 & 0,62 & 0,85 & 0,23 & 9 & - \\ \operatorname{cg} 22851875 & 0,69 & 0,35 & -0,34 & 5 & - \\ \operatorname{cg} 23804921 & 0,74 & 0,43 & -0,31 & 15 & - \\ & & & & & \\ \operatorname{cg} 01941243 & 0,74 & 0,51 & -0,22 & 1 & - \\ \operatorname{cg} 23892028 & 0,49 & 0,28 & -0,22 & 6 & - \\ \operatorname{cg} 18444757 & 0,84 & 0,64 & -0,21 & 18 & - \\ & & & & & \\ \operatorname{cg} 21388339 & 0,44 & 0,69 & 0,25 & 1 & \text { TP73;TP73;TP73;TP73 } \\ \operatorname{cg} 16995742 & 0,58 & 0,28 & -0,3 & 2 & \text { COPS8;COPS8 } \\ \operatorname{cg} 08024264 & 0,6 & 0,33 & -0,27 & 17 & \text { SCARNA16;C17orf86 } \\ \operatorname{cg} 19080354 & 0,42 & 0,66 & 0,25 & 11 & \text { ATHL1 } \\ \operatorname{cg} 02464073 & 0,65 & 0,35 & -0,3 & 21 & \text { ITGB2 } \\ \operatorname{cg} 02823625 & 0,8 & 0,6 & -0,2 & 2 & \text { KLHL30 } \\ \operatorname{cg} 01882774 & 0,78 & 0,57 & -0,21 & 14 & \text { OTUB2 } \\ \operatorname{cg} 00045070 & 0,15 & 0,44 & 0,29 & 1 & \text { PCSK9 } \\ \operatorname{cg} 01055691 & 0,59 & 0,79 & 0,2 & 3 & \text { GAP43;GAP43 } \\ \operatorname{cg} 08158105 & 0,89 & 0,66 & -0,23 & 12 & \text { BRI3BP } \\ & & & & & \\ \operatorname{cg} 22316634 & 0,6 & 0,83 & 0,23 & 19 & \text { COMP } \\ & & & & & \\ \operatorname{cg} 12129080 & 0,38 & 0,66 & 0,27 & 10 & \text { EBF3 } \\ \operatorname{cg} 07506153 & 0,56 & 0,83 & 0,27 & 10 & \text { EBF3 } \\ \operatorname{cg} 03466780 & 0,49 & 0,7 & 0,21 & 9 & \text { EXD3 } \\ \operatorname{cg} 18816122 & 0,39 & 0,66 & 0,27 & 5 & \text { PLEKHG4B } \\ \operatorname{cg} 06330797 & 0,89 & 0,65 & -0,25 & 6 & \text { RPS6KA2 } \\ \operatorname{cg} 07878625 & 0,84 & 0,62 & -0,23 & 7 & \text { ZNF783 } \\ & & & & & \end{array}$

\begin{tabular}{|c|c|c|c|c|}
\hline Body & N_Shelf & - & rs 12921753 & 0 \\
\hline Body & N_Shelf & - & rs256893 & 0 \\
\hline Body & N_Shelf & - & rs6496665 & rs2589974 \\
\hline Body & $N \_$Shelf & - & rs 10030377 & 0 \\
\hline Body & $N_{-}$Shelf & - & rs28417967 & 0 \\
\hline 5'UTR;5'UTR;5'UTR & N_Shelf & - & rs410456 & 0 \\
\hline \multicolumn{5}{|l|}{ 3'UTR;Body;3'UTR;3' } \\
\hline UTR & N_Shelf & - & rs6462371 & 0 \\
\hline 3'UTR & $N_{-}$Shelf & - & rs 1051508 & 0 \\
\hline \multirow{2}{*}{$\begin{array}{l}3 \text { 'UTR } \\
-\end{array}$} & $N \_$Shelf & - & rs3194515 & rs3194515 \\
\hline & N_Shelf & - & rs741847 & rs741847 \\
\hline- & N_Shelf & - & 0 & 0 \\
\hline- & $N \_$Shelf & - & rs79407054 & 0 \\
\hline- & $N_{-}$Shelf & - & rs56167783 & 0 \\
\hline \multirow[t]{2}{*}{-} & $N \_$Shelf & - & 0 & 0 \\
\hline & & & \multicolumn{2}{|r|}{ rs4653872,rs5701643 } \\
\hline- & $N \_$Shelf & - & 0 & 2 \\
\hline- & $N_{-}$Shelf & - & rs 3823427 & 0 \\
\hline- & $N \_$Shelf & - & rs627448 & rs627448 \\
\hline \multicolumn{5}{|l|}{ TSS1500;TSS1500; Bo } \\
\hline$d y ; \operatorname{TSS} 1500$ & N_Shore & - & rs3765725 & rs3765725 \\
\hline TSS1500;TSS1500 & N_Shore & - & rs 7577630 & rs 78584344 \\
\hline TSS1500;TSS1500 & N_Shore & - & rs531319 & rs36055056 \\
\hline TSS 1500 & N_Shore & - & rs 10751646 & rs 10751645 \\
\hline TSS 1500 & N_Shore & - & rs 1721 & rs62214473 \\
\hline TSS1500 & N_Shore & - & rs 28722660 & 0 \\
\hline TSS 1500 & N_Shore & - & rs34756202 & 0 \\
\hline TSS1500 & N_Shore & - & rs2479409 & 0 \\
\hline Body;5'UTR & N_Shore & - & rs10934303 & 0 \\
\hline \multirow[t]{2}{*}{ Body } & N_Shore & - & rs7303493 & rs 7303493 \\
\hline & & & \multicolumn{2}{|r|}{ rs 12327738, rs 123277} \\
\hline \multirow[t]{2}{*}{ Body } & N_Shore & - & rs 12327738 & 39 \\
\hline & & & \multicolumn{2}{|r|}{ rs11599715,rs766651 } \\
\hline Body & N_Shore & - & rs11599715 & 56 \\
\hline Body & N_Shore & - & rs 12572694 & 0 \\
\hline Body & N_Shore & - & rs28688712 & rs74488676 \\
\hline Body & N_Shore & - & rs 12522265 & rs 12522265 \\
\hline Body & N_Shore & - & rs7357046 & 0 \\
\hline Body & N_Shore & - & rs 10248661 & rs 10248661, rs 731625 \\
\hline
\end{tabular}


5'UTR;5'UTR;5'UTR;5

$\begin{array}{rrrrrr}\operatorname{cg} 01808284 & 0,55 & 0,76 & 0,21 & 5 & 4 ; \\ & & & & & \\ \operatorname{cg} 18827503 & 0,52 & 0,93 & 0,41 & 13 & - \\ \operatorname{cg} 00727777 & 0,42 & 0,77 & 0,34 & 8 & - \\ \operatorname{cg} 03871140 & 0,11 & 0,42 & 0,31 & 5 & - \\ & & & & & \\ \operatorname{cg} 16775095 & 0,4 & 0,64 & 0,24 & 15 & - \\ \operatorname{cg} 09916840 & 0,13 & 0,37 & 0,23 & 16 & - \\ \operatorname{cg} 10832239 & 0,48 & 0,69 & 0,21 & 14 & - \\ \operatorname{cg} 27625131 & 0,75 & 0,48 & -0,27 & 13 & - \\ \operatorname{cg} 03965172 & 0,79 & 0,58 & -0,21 & 4 & -\end{array}$

'UTR;5'UTR;5'UTR;5'

HTR4;HTR4;HTR4;HTR4;HTR

UTR

N_Shore

rs57644098

rs34055735

rs12864765,rs128647

rs12864765

- N_Shore

$N$ Shore

rs56268665

$N$ Shore - $\quad$ rs8032244

$N$ Shore - $\quad$ rs4843570

$-$

N_Shore

$N$ Shore

TSS200;TSS200;TSS2

PROMI·PROMI·PROMI·PRO $\quad 00 \cdot 5$ 'UTR·TSS200;TSS

$\begin{array}{llllrl}\operatorname{cg} 17858192 & 0,48 & 0,21 & -0,27 & 4 & \text { M1;PROM1;PROM1;PROM1 } \\ \operatorname{cg} 22984586 & 0,41 & 0,19 & -0,23 & 3 & \text { CCR5;CCR5 } \\ \operatorname{cg} 19949776 & 0,58 & 0,36 & -0,23 & 15 & \text { LOC100132724;AP4E1 }\end{array}$

200;5'UTR

TSS200;TSS200

Open sea

TSS200;Body

$\begin{array}{llll}\operatorname{cg} 14926231 & 0,83 & 0,56 & -0,27\end{array}$

2 C2Orf90

TSS200

$\begin{array}{llllll}\operatorname{cg} 25094735 & 0,58 & 0,78 & 0,21 & 19 & N A P S B\end{array}$

$\begin{array}{llllll}\operatorname{cg} 01463139 & 0,31 & 0,54 & 0,22 & 1 & \text { OR1OK1 }\end{array}$

$\begin{array}{llll}\operatorname{cg} 08600378 & 0,73 & 0,52 & -0,21\end{array}$

13 PRHOXNB

TSS200

TSS200

TSS200

$\begin{array}{llllll}\operatorname{cg} 22481673 & 0,42 & 0,79 & 0,38 & 1 & R D 3 ; R D 3\end{array}$

$\begin{array}{llllll}\operatorname{cg} 08514194 & 0,89 & 0,68 & -0,21 & 21 & \text { KRTAP12-4;C21orf } 29\end{array}$

$\begin{array}{llllll}\operatorname{cg} 23896850 & 0,45 & 0,66 & 0,21 & 17 & \text { TBC1D3H;TBC1D3C }\end{array}$

TSS1500;TSS1500

TSS1500;Body

TSS1500;Body

$\operatorname{cg} 17811452 \quad 0,4 \quad 0,6 \quad 0,21 \quad 20 \quad$ TP53TG5;SYS1-DBNDD2

TSS1500;Body

TSS1500;5'UTR;TSS1

$\begin{array}{lllrrl}\operatorname{cg} 22402398 & 0,86 & 0,64 & -0,22 & 1 & \text { FGR;FGR;FGR } \\ \operatorname{cg} 18709904 & 0,72 & 0,39 & -0,33 & 14 & \text { C14orf182 } \\ \operatorname{cg} 10482512 & 0,28 & 0,49 & 0,22 & 6 & \text { CCR6 } \\ \operatorname{cg} 07796016 & 0,71 & 0,48 & -0,22 & 1 & \text { LCE1C } \\ \operatorname{cg} 11680857 & 0,83 & 0,57 & -0,26 & 1 & \text { LCE2D } \\ \operatorname{cg} 13425888 & 0,82 & 0,61 & -0,21 & 19 & \text { NLRP2 } \\ \operatorname{cg} 02940070 & 0,82 & 0,58 & -0,23 & 22 & \text { PACSIN2 } \\ \operatorname{cg} 07258715 & 0,33 & 0,65 & 0,32 & 3 & \text { TMEM40 } \\ \operatorname{cg} 04990378 & 0,45 & 0,73 & 0,28 & 20 & \text { C20orf166;MIR133A2 } \\ \operatorname{cg} 07882838 & 0,38 & 0,61 & 0,22 & 15 & \text { SMAD3;SMAD3 }\end{array}$

TSS 1500

TSS 1500

TSS 1500

TSS1500

TSS 1500

TSS 1500

TSS 1500

Body;TSS 1500

Body;TSS 1500

Open sea

Open sea

Open sea

Open sea

Open sea

Open sea

Open sea

Open sea

Open sea

Open sea

Open sea

Open sea

Open sea

Open sea

Open sea

Open sea

Open sea

Open sea

Open sea

rs4843570

rs9577762

rs 2880892

rs56268665

rs2469078,rs4776813

,rs8032244

rs79244768

rs35880313

13
0

rs4698134

rs2227010

rs8031702

rs6708283

rs59323905

rs1573519

rs3897927

rs12733443,

rs76537925

rs 2838613

rs4438352

rs2231610

rs1890462

rs 2355655

rs2021033

rs28408574

rs11205062

0
$\mathrm{rs} 5759053$

rs9865548

rs6143047

rs11071937

0

0

0

49

0

5

$\begin{array}{rr}0 & 0 \\ 0 & 0\end{array}$

rs76253543

rs6708283

0
$+s 1002599$

0

rs76537925

rs 2838613

rs4438352

rs2741642

0

rs78056730

$0 \quad 30$

0

rs 1671187

rs73176879

$\begin{array}{rr}0 & 50 \\ 0 & 0 \\ 0 & 0\end{array}$




\begin{tabular}{|c|c|c|c|c|c|c|c|c|c|c|c|}
\hline $\operatorname{cg} 03978067$ & 0,61 & 0,89 & 0,28 & 8 & $\begin{array}{l}\text { EEF1D;EEF1D;EEF1D;EEF1 } \\
D ; E E F 1 D ; E E F 1 D ; E E F 1 D \\
L G A L S 8 ; L G A L S 8 ; L G A L S 8 ; L G\end{array}$ & $\begin{array}{l}\text { Body;Body;Body;Body; } \\
\text { Body;Body;Body }\end{array}$ & Open sea & - & rs58477175 & rs62523609 & 0 \\
\hline $\operatorname{cg} 14252149$ & 0,27 & 0,47 & 0,2 & 1 & $\begin{array}{l}\text { ALS8 } \\
\text { SLC39A14;SLC39A14;SLC39A }\end{array}$ & Body;Body;Body;Body & Open sea & - & rs2799409 & rs41305947 & 0 \\
\hline $\operatorname{cg} 27467876$ & 0,81 & 0,47 & $-0,34$ & 8 & $14 ; S L C 39 A 14$ & Body;Body;Body;Body & Open sea & - & rs 13266541 & 0 & 0 \\
\hline $\operatorname{cg} 04467639$ & 0,34 & 0,56 & 0,21 & 11 & COPB $1 ; C O P B 1 ; C O P B 1$ & Body;Body;Body & Open sea & - & rs55665837 & $\begin{array}{r}0 \\
\text { rs 1014779, rs } 7914482\end{array}$ & 50 \\
\hline $\operatorname{cg} 00023507$ & 0,35 & 0,61 & 0,26 & 6 & TAPBP;TAPBP;TAPBP & Body;Body;Body & Open sea & - & rs 1014779 & 0 & 50 \\
\hline $\operatorname{cg} 07227024$ & 0,16 & 0,53 & 0,37 & 2 & ALS2CR12;ALS2CR12 & Body;Body & Open sea & - & rs9288316 & rs79654660 & 0 \\
\hline $\operatorname{cg} 10724632$ & 0,37 & 0,57 & 0,2 & 2 & COLEC11;COLEC11 & Body;Body & Open sea & - & rs12475572 & 0 & 0 \\
\hline $\operatorname{cg} 14117565$ & 0,58 & 0,84 & 0,25 & 19 & $E T F B ; E T F B$ & Body;Body & Open sea & - & rs8111973 & 0 & 0 \\
\hline $\operatorname{cg} 18828306$ & 0,71 & 0,51 & $-0,2$ & 11 & USH1C;USHIC & Body;Body & Open sea & - & rs 10766409 & 0 & 0 \\
\hline $\operatorname{cg} 22491001$ & 0,68 & 0,89 & 0,22 & 13 & $C O L 4 A 2$ & Body & Open sea & - & rs41275118 & $\begin{array}{r}\mathrm{rs} 368115, \mathrm{rs} 409345 \\
\mathrm{rs} 12544891, \mathrm{rs} 571020\end{array}$ & 0 \\
\hline $\operatorname{cg} 00259849$ & 0,58 & 0,87 & 0,3 & 8 & CSMD1 & Body & Open sea & - & $\begin{array}{r}\mathrm{rs} 10046752 \\
\mathrm{rs} 12544891\end{array}$ & $\begin{array}{r}73, \text { rs } 76621828, \text { rs } 931 \\
4524\end{array}$ & 0 \\
\hline $\operatorname{cg} 06813297$ & 0,62 & 0,86 & 0,25 & 12 & EP400 & Body & Open sea & - & rs10902488 & $\begin{array}{r}\mathrm{rs} 10902488 \\
\mathrm{rs} 28421120, \mathrm{rs} 285339\end{array}$ & 0 \\
\hline $\operatorname{cg} 13160627$ & 0,61 & 0,91 & 0,29 & 7 & FAM20C & Body & Open sea & - & rs28421120 & 95 & 0 \\
\hline $\operatorname{cg} 23285059$ & 0,57 & 0,77 & 0,2 & 8 & FAM66A & Body & Open sea & - & 0 & 0 & 0 \\
\hline $\operatorname{cg} 03040740$ & 0,82 & 0,57 & $-0,24$ & 13 & FARP1 & Body & Open sea & - & rs9517292 & rs6491426,rs9517292 & 11 \\
\hline $\operatorname{cg} 09438069$ & 0,54 & 0,75 & 0,21 & 4 & FAT1 & Body & Open sea & - & rs7672848 & 0 & 0 \\
\hline $\operatorname{cg} 20479209$ & 0,75 & 0,46 & $-0,29$ & 8 & FLJ43860 & Body & Open sea & - & rs2748404 & rs2748404 & 0 \\
\hline $\operatorname{cg} 09510698$ & 0,47 & 0,78 & 0,3 & 6 & $H L A-D P B 2$ & Body & Open sea & - & $\begin{array}{r}\text { rs9277731 } \\
\text { rs34041546, }\end{array}$ & 0 & 20 \\
\hline $\operatorname{cg} 10995422$ & 0,75 & 0,37 & $-0,39$ & 6 & $H L A-D R B 6$ & Body & Open sea & - & rs67218022 & rs36215042 & 0 \\
\hline $\operatorname{cg} 06559318$ & 0,74 & 0,47 & $-0,27$ & 6 & $H L A-D R B 6$ & Body & Open sea & - & 0 & rs 28679786 & 0 \\
\hline $\operatorname{cg} 00103771$ & 0,8 & 0,54 & $-0,26$ & 6 & $H L A-D R B 6$ & Body & Open sea & - & 0 & rs57583084 & 0 \\
\hline $\operatorname{cg} 19393008$ & 0,54 & 0,34 & $-0,2$ & 12 & KRT82 & Body & Open sea & - & rs928993 & 0 & 0 \\
\hline $\operatorname{cg} 11716267$ & 0,57 & 0,32 & $-0,25$ & 2 & LOC375190 & Body & Open sea & - & rs35331966 & 0 & 49 \\
\hline $\operatorname{cg} 25598710$ & 0,66 & 0,87 & 0,21 & 2 & LOC440839 & Body & Open sea & - & 0 & rs 13411628 & 0 \\
\hline $\operatorname{cg} 12466610$ & 0,18 & 0,41 & 0,23 & 1 & MOSC2 & Body & Open sea & - & rs12402066 & rs76495903 & 0 \\
\hline $\operatorname{cg} 17770035$ & 0,11 & 0,38 & 0,27 & 6 & $N C R 2$ & Body & Open sea & - & rs6458216 & 0 & 50 \\
\hline $\operatorname{cg} 02978201$ & 0,61 & 0,38 & $-0,23$ & 16 & PRMI & Body & Open sea & - & rs 737008 & $\begin{array}{r}0 \\
\text { rs10049791,rs100497 }\end{array}$ & 0 \\
\hline $\operatorname{cg} 07082484$ & 0,74 & 0,53 & $-0,21$ & 4 & $S H 3 R F 1$ & Body & Open sea & - & rs 10049792 & 92 & 50 \\
\hline $\operatorname{cg} 14195178$ & 0,86 & 0,64 & $-0,22$ & 17 & $T B C D$ & Body & Open sea & - & rs12938918 & rs73366955 & 0 \\
\hline $\operatorname{cg} 15561493$ & 0,8 & 0,53 & $-0,27$ & 7 & $V W D E$ & Body & Open sea & - & rs17190390 & 0 & 0 \\
\hline
\end{tabular}




\begin{tabular}{|c|c|c|c|c|c|c|c|c|c|c|c|}
\hline $\operatorname{cg} 01326421$ & 0,62 & 0,41 & $-0,21$ & 20 & $\begin{array}{l}\text { SLC23A2;SLC23A2 } \\
\text { GALNTL5;GALNTL5;GALNTL }\end{array}$ & 5'UTR;TSS1500 & Open sea & - & rs 1279683 & $\begin{array}{r}\mathrm{rs} 2423084 \\
\mathrm{rs} 11762439, \mathrm{rs} 117624\end{array}$ & 0 \\
\hline $\operatorname{cg} 11727304$ & 0,5 & 0,82 & 0,33 & 7 & 5 & 5'UTR;Body;1stExon & Open sea & - & rs 11762439 & 74 & 0 \\
\hline $\operatorname{cg} 00689685$ & 0,78 & 0,56 & $-0,22$ & 6 & $A G P A T 1 ; A G P A T 1$ & 5'UTR;5'UTR & Open sea & - & rs9267817 & 0 & 50 \\
\hline $\operatorname{cg} 07271471$ & 0,56 & 0,84 & 0,28 & 13 & SPATA13;SPATA13 & 5'UTR;5'UTR & Open sea & - & rs9511154 & 0 & 0 \\
\hline $\operatorname{cg} 25232888$ & 0,67 & 0,92 & 0,26 & 11 & OSBPL5; OSBPL5;OSBPL5 & 3'UTR;3'UTR;3'UTR & Open sea & - & rs8813 & rs59828116,rs8813 & 0 \\
\hline $\operatorname{cg} 07437923$ & 0,06 & 0,37 & 0,32 & 16 & DNAJA3;DNAJA3 & 3'UTR;3'UTR & Open sea & - & rs4786494 & 0 & 0 \\
\hline $\operatorname{cg} 10818676$ & 0,44 & 0,74 & 0,3 & 1 & DUSP27 & 3'UTR & Open sea & - & rs66619221 & rs75932332 & 0 \\
\hline $\operatorname{cg} 22098780$ & 0,35 & 0,58 & 0,24 & 17 & EFNB3 & 3'UTR & Open sea & - & rs3744262 & 0 & 0 \\
\hline $\operatorname{cg} 10613426$ & 0,85 & 0,64 & $-0,22$ & 19 & ELSPBP1 & 3'UTR & Open sea & - & rs73567249 & 0 & 0 \\
\hline $\operatorname{cg} 16675926$ & 0,49 & 0,71 & 0,22 & 1 & KIAA1804 & 3'UTR & Open sea & - & rs 1294233 & $\begin{array}{r}0 \\
\text { rs70937082,rs709370 }\end{array}$ & 0 \\
\hline $\operatorname{cg} 04033559$ & 0,5 & 0,7 & 0,2 & 2 & $P D K 1$ & 3'UTR & Open sea & - & rs11904158 & 83 & 0 \\
\hline $\operatorname{cg} 26584456$ & 0,5 & 0,29 & $-0,21$ & 10 & $P P I F$ & 3'UTR & Open sea & - & rs7332 & rs11002941 & 0 \\
\hline $\operatorname{cg} 17196155$ & 0,42 & 0,7 & 0,28 & 7 & $X R C C 2$ & 3'UTR & Open sea & - & rs3218544 & rs 3218545 & 10 \\
\hline $\operatorname{cg} 02262167$ & 0,54 & 0,84 & 0,3 & 13 & - & - & Open sea & - & rs 1163860 & $\begin{array}{r}\mathrm{rs} 1163860 \\
\text { rs73376840,rs779774 }\end{array}$ & 0 \\
\hline $\operatorname{cg} 02372404$ & 0,17 & 0,46 & 0,3 & 10 & - & - & Open sea & - & $\begin{array}{r}\text { rs877430 } \\
\text { rs2103033,rs }\end{array}$ & 51 & 0 \\
\hline $\operatorname{cg} 12074150$ & 0,21 & 0,49 & 0,28 & 2 & - & - & Open sea & - & 1705134 & rs2103033 & 47 \\
\hline $\operatorname{cg} 10526376$ & 0,4 & 0,68 & 0,28 & 2 & - & - & Open sea & - & rs6751291 & rs6751291 & 50 \\
\hline $\operatorname{cg} 27154731$ & 0,18 & 0,46 & 0,28 & 6 & - & - & Open sea & - & rs9455487 & rs9455730 & 0 \\
\hline $\operatorname{cg} 02890235$ & 0,55 & 0,81 & 0,26 & 19 & - & - & Open sea & - & rs12610801 & rs12610801 & 0 \\
\hline $\operatorname{cg} 02389264$ & 0,46 & 0,71 & 0,25 & 16 & - & - & Open sea & - & rs57577962 & rs76295440 & 0 \\
\hline $\operatorname{cg} 24007926$ & 0,4 & 0,64 & 0,25 & 2 & - & - & Open sea & - & rs6435323 & rs6435323 & 50 \\
\hline $\operatorname{cg} 25247689$ & 0,51 & 0,75 & 0,24 & 12 & - & - & Open sea & - & rs11062351 & rs 11062351 & 0 \\
\hline $\operatorname{cg} 09233619$ & 0,56 & 0,77 & 0,21 & 11 & - & - & Open sea & - & $\begin{array}{r}\text { rs } 12280034 \\
\text { rs } 7085446, \mathrm{rs}\end{array}$ & 0 & 49 \\
\hline $\operatorname{cg} 23954274$ & 0,41 & 0,62 & 0,21 & 10 & - & - & Open sea & - & 11017945 & rs7085446 & 0 \\
\hline $\operatorname{cg} 00523628$ & 0,36 & 0,56 & 0,2 & 6 & - & - & Open sea & - & rs56180715 & $\begin{array}{r}0 \\
\text { rs74813460,rs760138 } \\
92, \text { rs } 77148470, \text { rs } 943\end{array}$ & 29 \\
\hline $\operatorname{cg} 22337407$ & 0,67 & 0,39 & $-0,28$ & 1 & - & - & Open sea & - & rs77148470 & 0328 & 50 \\
\hline $\operatorname{cg} 17851276$ & 0,53 & 0,29 & $-0,24$ & 4 & - & - & Open sea & - & 0 & $\begin{array}{r}0 \\
\text { rs34905813,rs960738 }\end{array}$ & 0 \\
\hline $\operatorname{cg} 09219182$ & 0,61 & 0,87 & 0,26 & 22 & $N C F 4 ; N C F 4$ & TSS1500;TSS1500 & S_Shelf & - & rs9607387 & 7 & 36 \\
\hline $\operatorname{cg} 22336867$ & 0,06 & 0,29 & 0,23 & 19 & $L G A L S 7$ & TSS 1500 & S_Shelf & - & rs4801877 & 0 & 0 \\
\hline $\operatorname{cg} 21211688$ & 0,39 & 0,78 & 0,39 & 9 & ADAMTSL2;ADAMTSL2 & Body;Body & S_Shelf & - & rs 1858839 & rs1858839 & 0 \\
\hline $\operatorname{cg} 05374367$ & 0,31 & 0,54 & 0,23 & 14 & C14orf70 & Body & S_Shelf & - & rs 8017950 & rs 8017950 & 0 \\
\hline
\end{tabular}




\begin{tabular}{|c|c|c|c|c|c|}
\hline $\operatorname{cg} 24801230$ & 0,4 & 0,65 & 0,25 & 17 & $\begin{array}{l}\text { МАPT;MAP } \\
A P T ; M A P T\end{array}$ \\
\hline cg13989295 & 0,52 & 0,27 & $-0,24$ & 17 & $S K A 2 ; S K A 2$ \\
\hline cg11663691 & 0,32 & 0,64 & 0,32 & 4 & - \\
\hline $\operatorname{cg} 20554557$ & 0,37 & 0,69 & 0,32 & 6 & - \\
\hline $\operatorname{cg} 07149469$ & 0,58 & 0,87 & 0,29 & 13 & - \\
\hline $\operatorname{cg} 12293347$ & 0,56 & 0,79 & 0,22 & 8 & - \\
\hline $\operatorname{cg} 12981577$ & 0,73 & 0,42 & $-0,31$ & 3 & - \\
\hline cg00814186 & 0,69 & 0,39 & $-0,31$ & 17 & - \\
\hline cg21783012 & 0,67 & 0,39 & $-0,29$ & 1 & - \\
\hline cg24906015 & 0,82 & 0,56 & $-0,26$ & 2 & - \\
\hline $\operatorname{cg} 04277055$ & 0,89 & 0,63 & $-0,26$ & 4 & - \\
\hline $\operatorname{cg} 18669823$ & 0,75 & 0,51 & $-0,24$ & 7 & - \\
\hline cg26035071 & 0,72 & 0,48 & $-0,24$ & 1 & - \\
\hline $\operatorname{cg} 16576930$ & 0,8 & 0,57 & $-0,24$ & 8 & - \\
\hline cg05708441 & 0,9 & 0,69 & $-0,22$ & 2 & - \\
\hline $\operatorname{cg} 11857805$ & 0,68 & 0,46 & $-0,21$ & 14 & - \\
\hline cg26702098 & 0,83 & 0,63 & $-0,2$ & 8 & - \\
\hline $\operatorname{cg} 00231519$ & 0,54 & 0,83 & 0,3 & 10 & C10orf46 \\
\hline cg09084244 & 0,25 & 0,48 & 0,23 & 12 & $C D K 2 A P 1$ \\
\hline cg01836455 & 0,8 & 0,57 & $-0,23$ & 6 & KHDCl \\
\hline cg05023192 & 0,57 & 0,33 & $-0,24$ & 2 & NDUFA10 \\
\hline $\operatorname{cg} 15295200$ & 0,51 & 0,79 & 0,28 & 3 & $\begin{array}{l}\text { NMNAT3 } \\
\text { BRUNOL4; }\end{array}$ \\
\hline cg20094343 & 0,6 & 0,33 & $-0,26$ & 18 & $L 4 ; B R U N O$ \\
\hline $\operatorname{cg} 06651180$ & 0,6 & 0,87 & 0,27 & 7 & $C U X 1 ; C U X$ \\
\hline cg20550012 & 0,45 & 0,74 & 0,29 & 7 & $P T P R N 2 ; P$ \\
\hline cg24688871 & 0,56 & 0,78 & 0,23 & 1 & Clorf93 \\
\hline cg23098789 & 0,44 & 0,84 & 0,4 & 10 & GPR123 \\
\hline $\operatorname{cg} 10632894$ & 0,64 & 0,42 & $-0,22$ & 6 & $H L A-D R B 1$ \\
\hline cg21209485 & 0,76 & 0,5 & $-0,26$ & 1 & MMEL1 \\
\hline $\operatorname{cg} 13573375$ & 0,35 & 0,59 & 0,24 & 19 & PIAS4 \\
\hline $\operatorname{cg} 26526047$ & 0,88 & 0,66 & $-0,22$ & 10 & KIAA1217 \\
\hline cg26690407 & 0,21 & 0,52 & 0,32 & 5 & - \\
\hline
\end{tabular}

3'UTR;3'UTR

$S$ Shelf

S_Shelf

S_Shelf

$S$ Shelf

S_Shelf

S_Shelf

$S$ Shelf

S_Shelf

S_Shelf

S_Shelf

S_Shelf

$S$ Shelf

S_Shelf

$S$ Shelf

$S$ Shelf

$S$ Shelf

TSS 1500

TSS 1500

TSS 1500

TSS 1500

TSS 1500

S_Shore

$S$ Shore

S_Shore

$S$ Shore

S_Shore

Body;Body;Body;Body S Shore

Body;Body;Body

Body;Body;Body

Body

Body

$S$ Shore

S_Shore

$S$ Shore

S_Shore

\section{Body \\ Body \\ Body}

rs 1560310

rs7208505

rs2052769

rs13203041

rs4769398

rs62487550

rs2178384

rs4471711

rs67373773

rs11901899

rs10002013,

rs 10002197

rs6946024

rs6659367

rs 10109265

rs1880989

rs1191030

rs6992483

rs36101953

rs1109559

rs7740081

rs 10153593

rs3922621

rs59213378

rs 123779

rs6701238

rs12359671

S_Shore

$S$ Shore

$S$ Shore

S_Shore

$S$ Shore

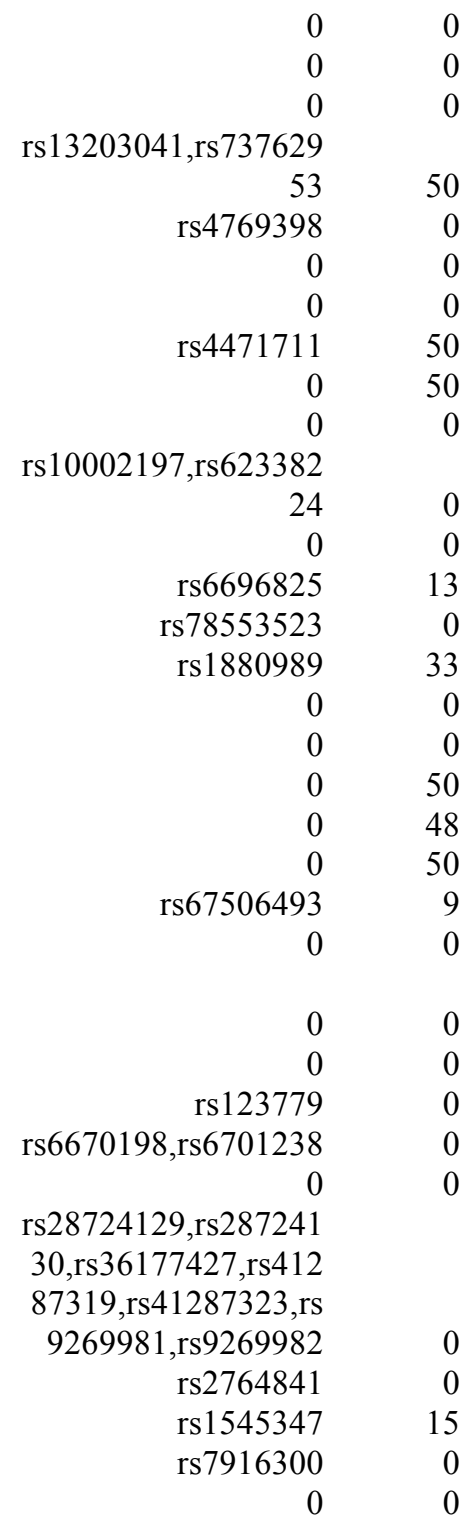




\begin{tabular}{|c|c|c|c|c|c|c|c|c|c|c|}
\hline $\operatorname{cg} 15567368$ & 0,3 & 0,61 & 0,31 & 7 & - & - & S_Shore & - & rs35986921 & $\begin{array}{r}0 \\
97, \mathrm{rs} 734880\end{array}$ \\
\hline $\operatorname{cg} 19216631$ & 0,51 & 0,79 & 0,28 & 7 & - & - & S_Shore & - & rs 13224097 & 11 \\
\hline $\operatorname{cg} 22996768$ & 0,1 & 0,32 & 0,22 & 19 & - & - & S_Shore & - & rs 4805863 & rs78339796 \\
\hline $\operatorname{cg} 07498088$ & 0,79 & 0,52 & $-0,27$ & 10 & - & - & Shore & - & rs2001324 & 0 \\
\hline
\end{tabular}

$\mathrm{D}=$ identificação da sonda correspondente ao CpG; C.B = média do valor de Beta para o grupo controle; DA.B = média do valor de Beta para o grupo doença de Alzheimer (DA); DB = valor de Delta Beta; DI Ilha = distância em relação a ilha CpG; Shore = distante 0-2 Kb da Ilha CpG; Shelf= distante 2-4 Kb e Open sea $=$ distante $>4 \mathrm{~Kb}$; $N$ e $S$ quando estão referenciadas a Shore e Shelf indica localização norte e sul (North e South); Reg Amp = região amplificadora; CpG_SNP = CpG associados a SNPs; Seq Rep = número de pares de bases que a sonda pareia em sequência repetitiva; TSS = Transcription Start Site, sítio de início de transcrição; TSS1500 e TSS $2200=$ CpG localizado a 1500 e 2200 pares de base do sítio de início de transcrição, respectivamente; Body = corpo do gene. Repetições na distribuição genômica funcional indica mais que um transcrito. 

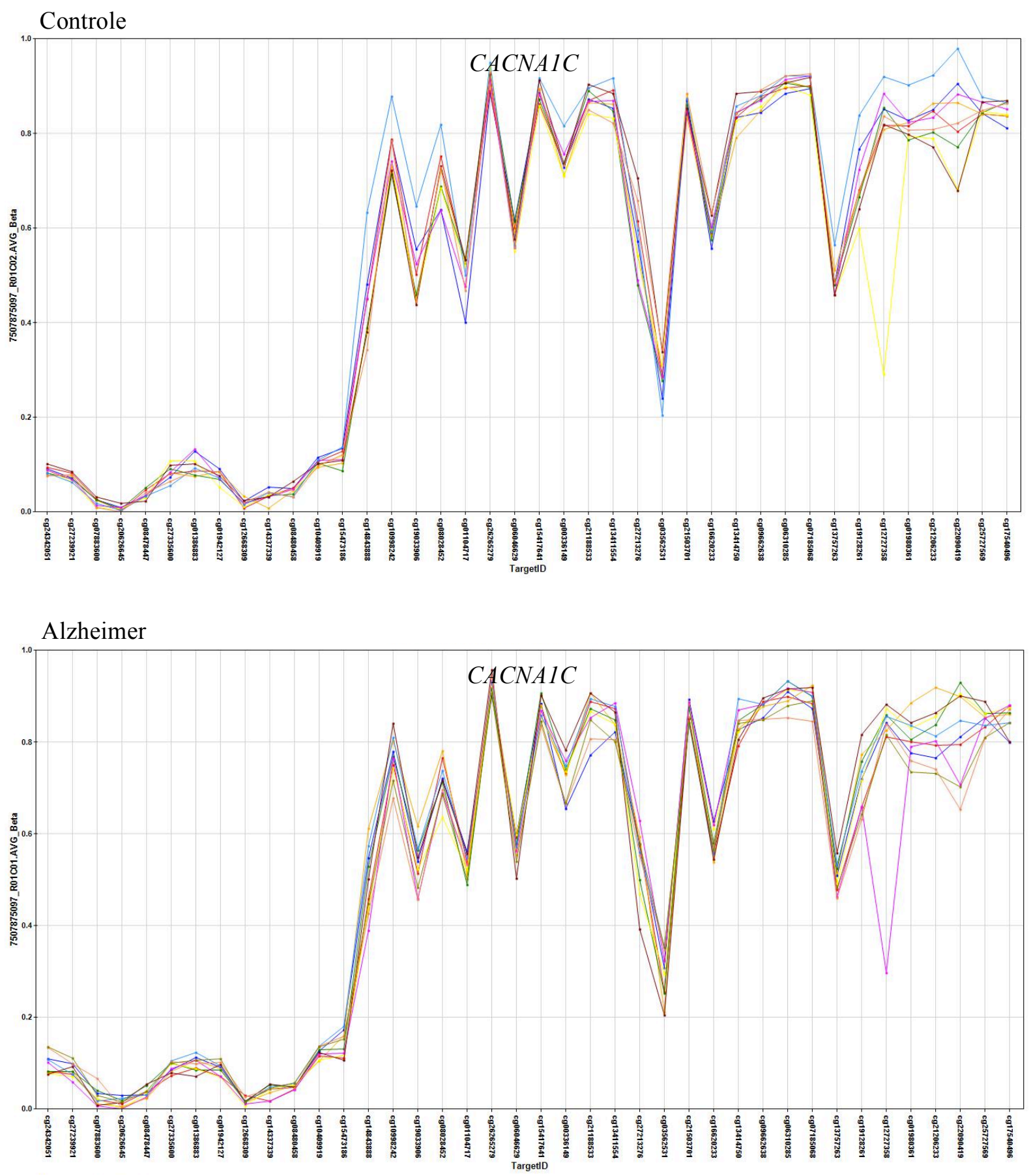

Figura S1. Distribuição dos níveis de metilação ao longo de todos os sítios CpG do gene CACNA1C. Cada linha representa um indivíduo e cada ponto equivale a um sítio $\mathrm{CpG}$ com seu respectivo valor de Beta. Imagem extraída do programa computacional Genome Studio. 

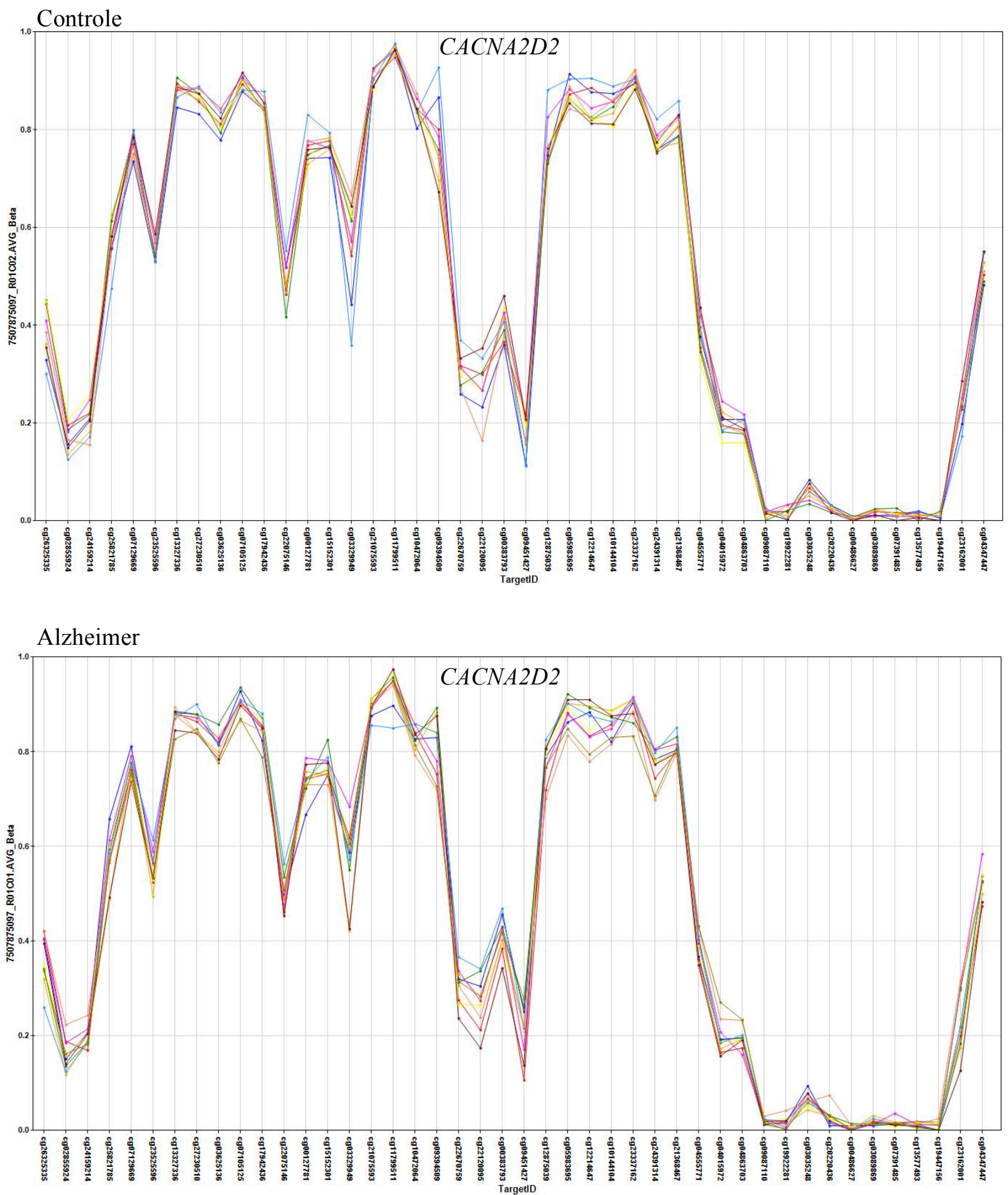

Figura S2. Distribuição dos níveis de metilação ao longo de todos os sítios CpG do gene CACNA2D2. Cada linha representa um indivíduo e cada ponto equivale a um sítio $\mathrm{CpG}$ com seu respectivo valor de Beta. Imagem extraída do programa computacional Genome Studio. 



Figura S3. Distribuição dos níveis de metilação ao longo de todos os sítios CpG do gene CACNA2D3. Cada linha representa um indivíduo e cada ponto equivale a um sítio $\mathrm{CpG}$ com seu respectivo valor de Beta. Imagem extraída do programa computacional Genome Studio. 

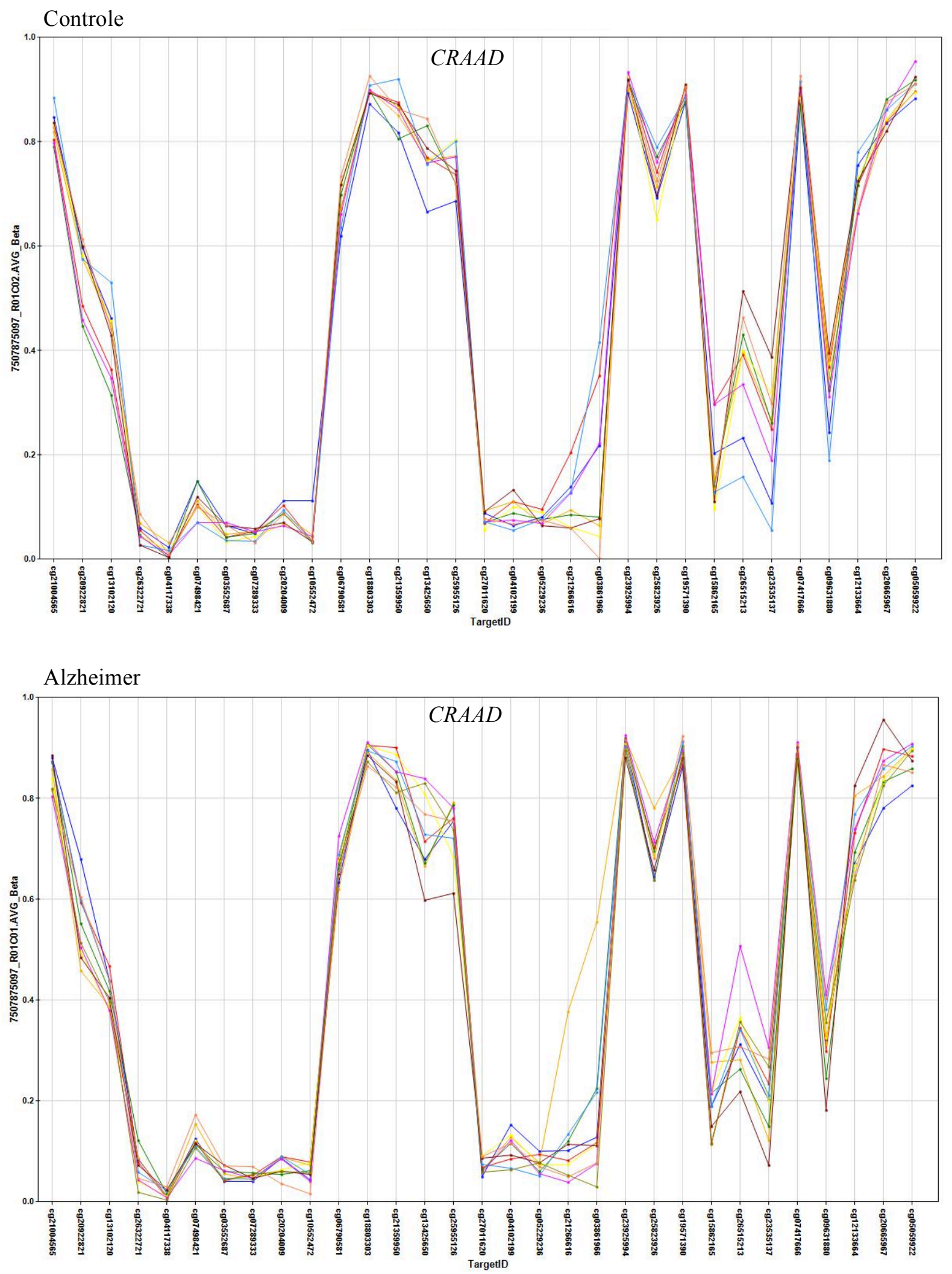

Figura S4. Distribuição dos níveis de metilação ao longo de todos os sítios CpG do gene $C R A A D$. Cada linha representa um indivíduo e cada ponto equivale a um sítio $\mathrm{CpG}$ com seu respectivo valor de Beta. Imagem extraída do programa computacional Genome Studio. 

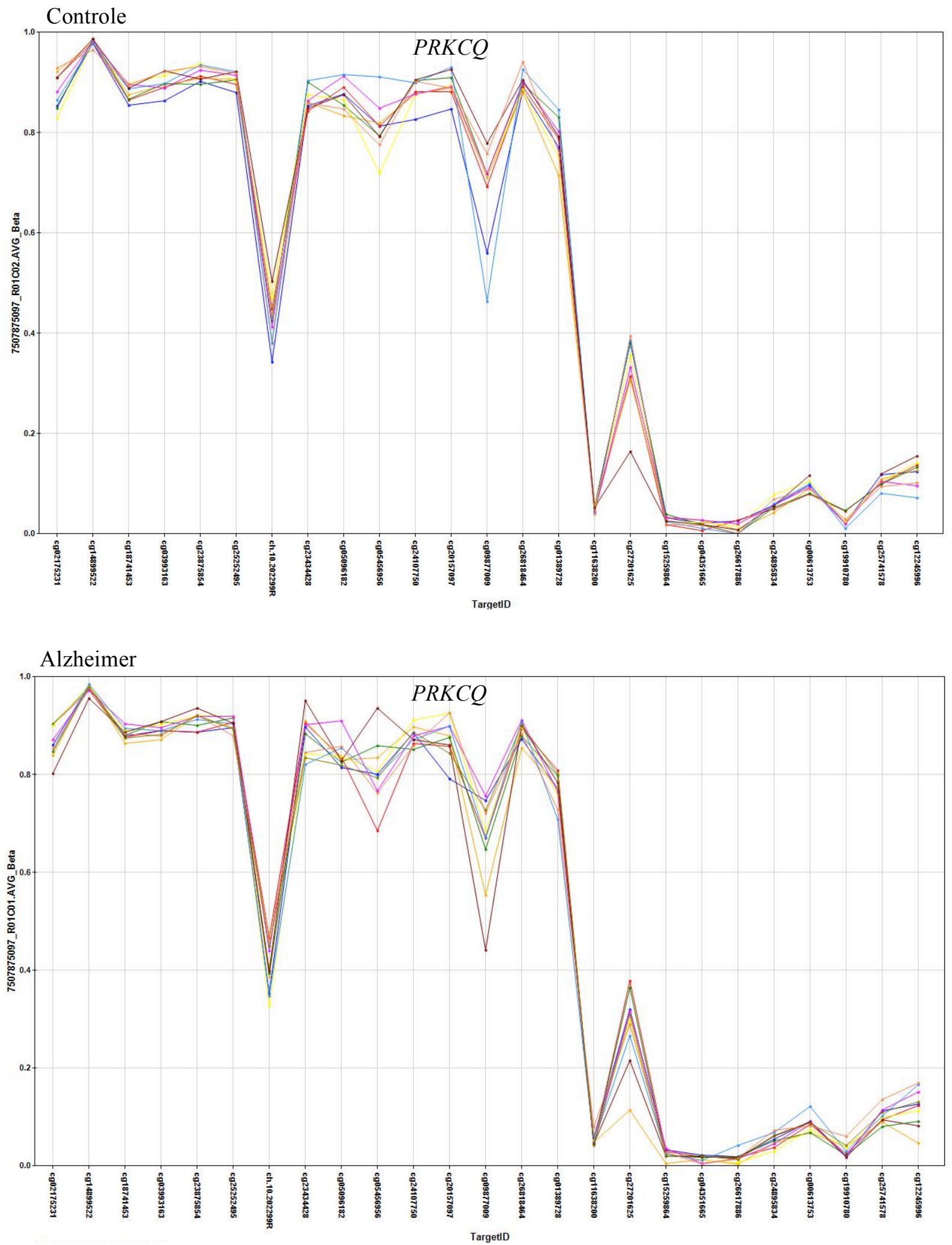

Figura S5. Distribuição dos níveis de metilação ao longo de todos os sítios CpG do gene $P R K C Q$. Cada linha representa um indivíduo e cada ponto equivale a um sítio $\mathrm{CpG}$ com seu respectivo valor de Beta. Imagem extraída do programa computacional Genome Studio. 

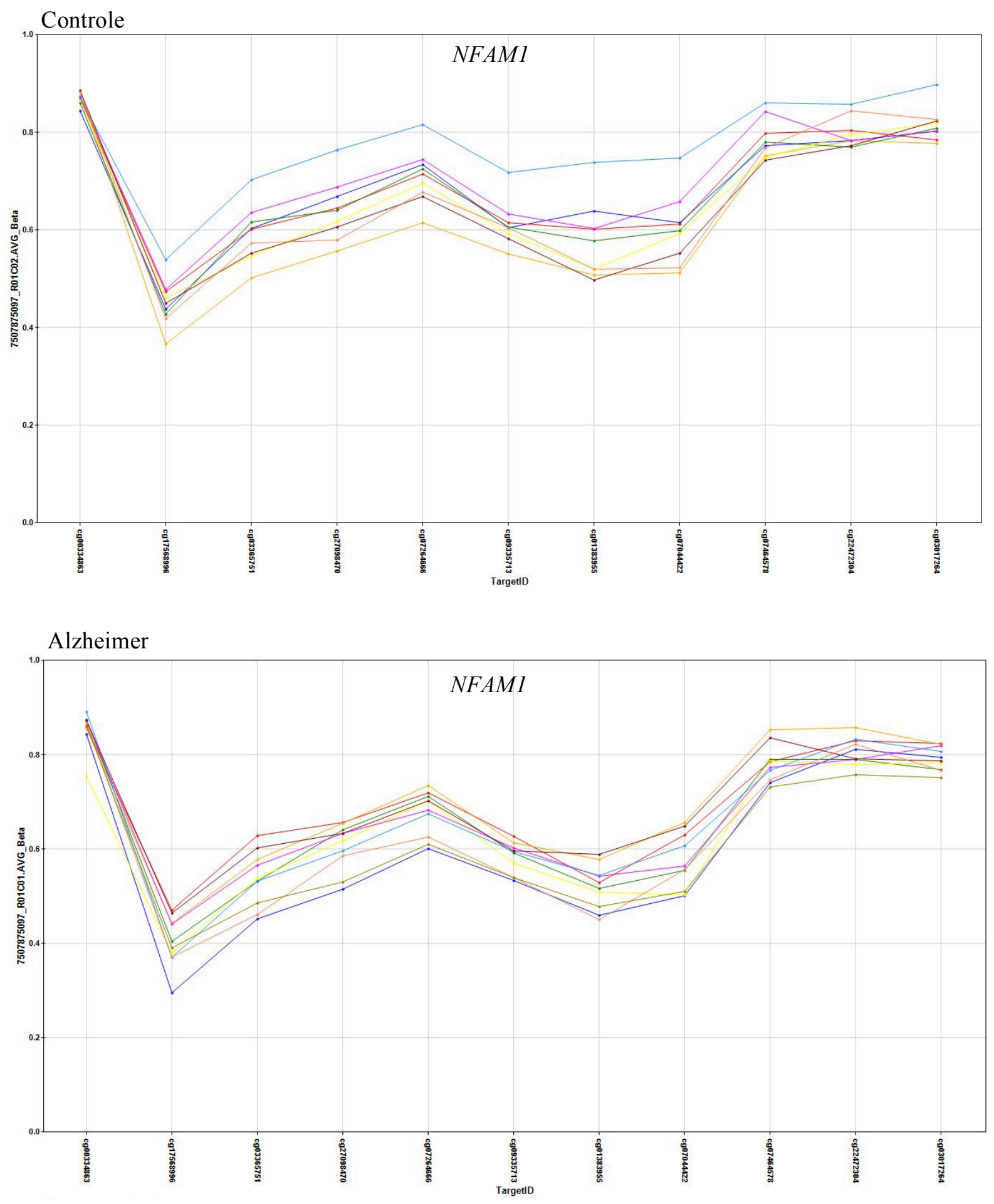

Figura S6. Distribuição dos níveis de metilação ao longo de todos os sítios CpG do gene NFAM1. Cada linha representa um indivíduo e cada ponto equivale a um sítio $\mathrm{CpG}$ com seu respectivo valor de Beta. Imagem extraída do programa computacional Genome Studio. 

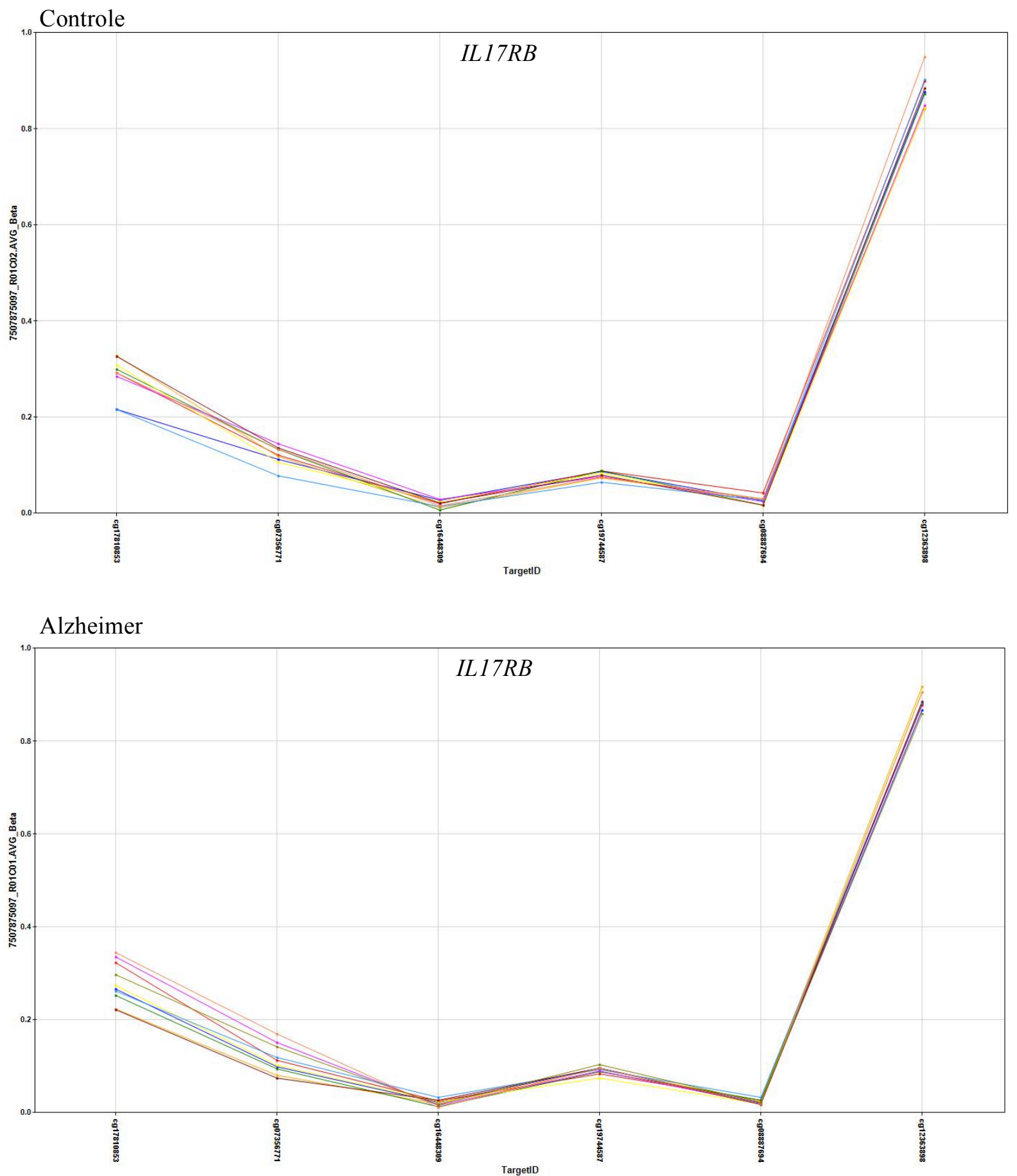

Figura S7. Distribuição dos níveis de metilação ao longo de todos os sítios CpG do gene $I L 17 R B$. Cada linha representa um indivíduo e cada ponto equivale a um sítio $\mathrm{CpG}$ com seu respectivo valor de Beta. Imagem extraída do programa computacional Genome Studio. 

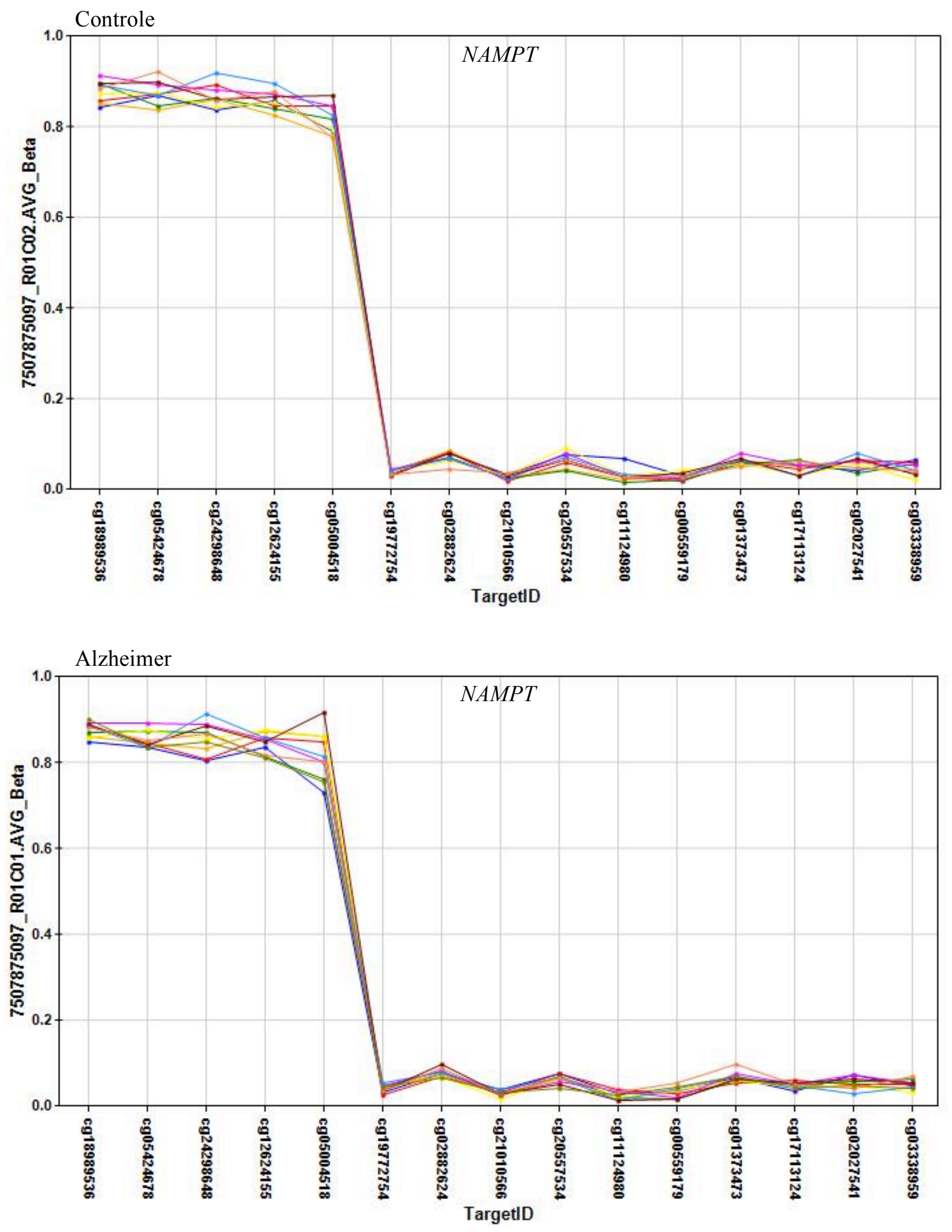

Figura S8. Distribuição dos níveis de metilação ao longo de todos os sítios CpG do gene NAMPT. Cada linha representa um indivíduo e cada ponto equivale a um sítio $\mathrm{CpG}$ com seu respectivo valor de Beta. Imagem extraída do programa computacional Genome Studio. 



Figura S9. Distribuição dos níveis de metilação ao longo de todos os sítios CpG do gene $\boldsymbol{A P O E}$. Cada linha representa um indivíduo e cada ponto equivale a um sítio $\mathrm{CpG}$ com seu respectivo valor de Beta. Imagem extraída do programa computacional Genome Studio. 

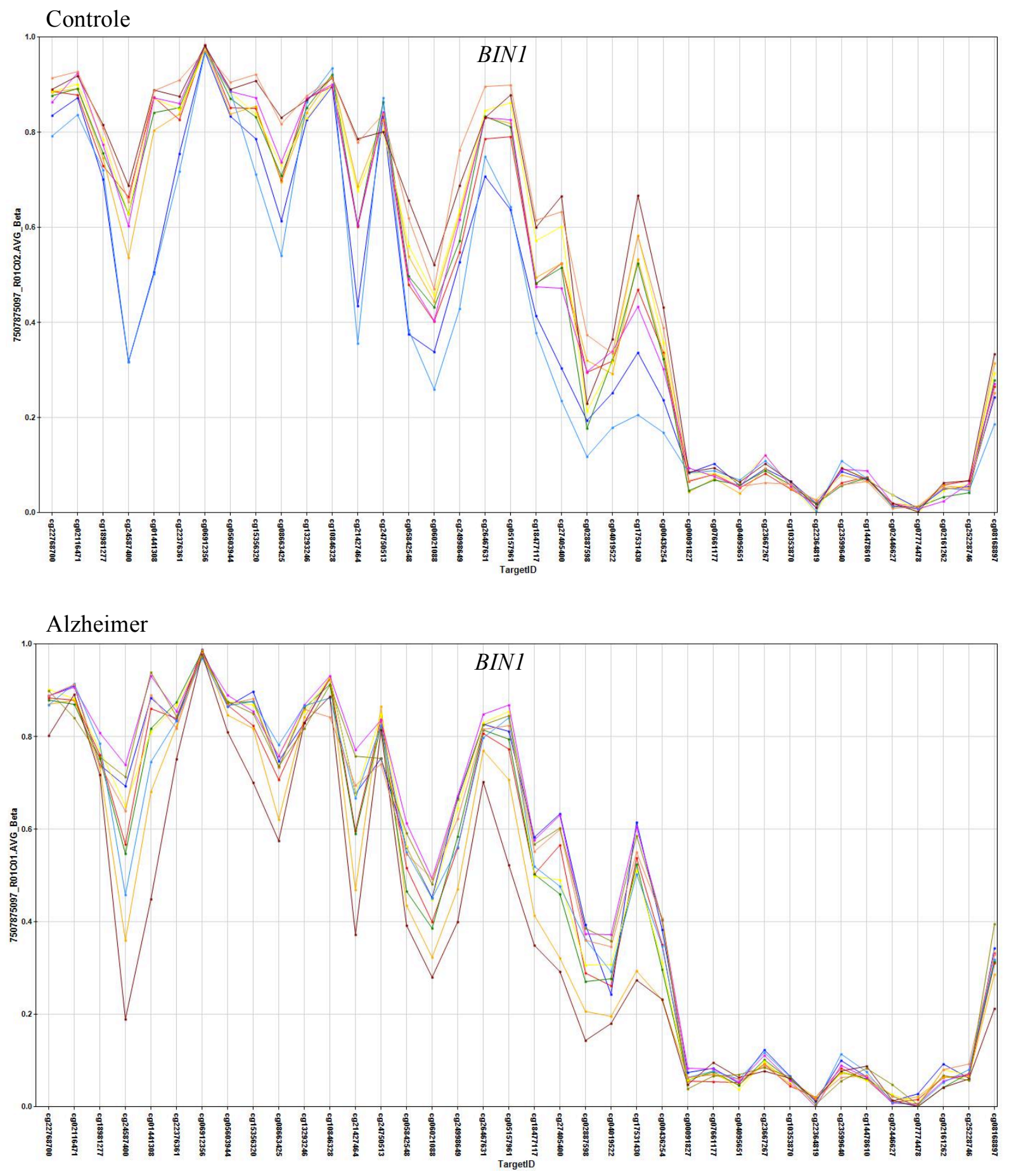

Figura S10. Distribuição dos níveis de metilação ao longo de todos os sítios CpG do gene BIN1. Cada linha representa um indivíduo e cada ponto equivale a um sítio $\mathrm{CpG}$ com seu respectivo valor de Beta. Imagem extraída do programa computacional Genome Studio. 

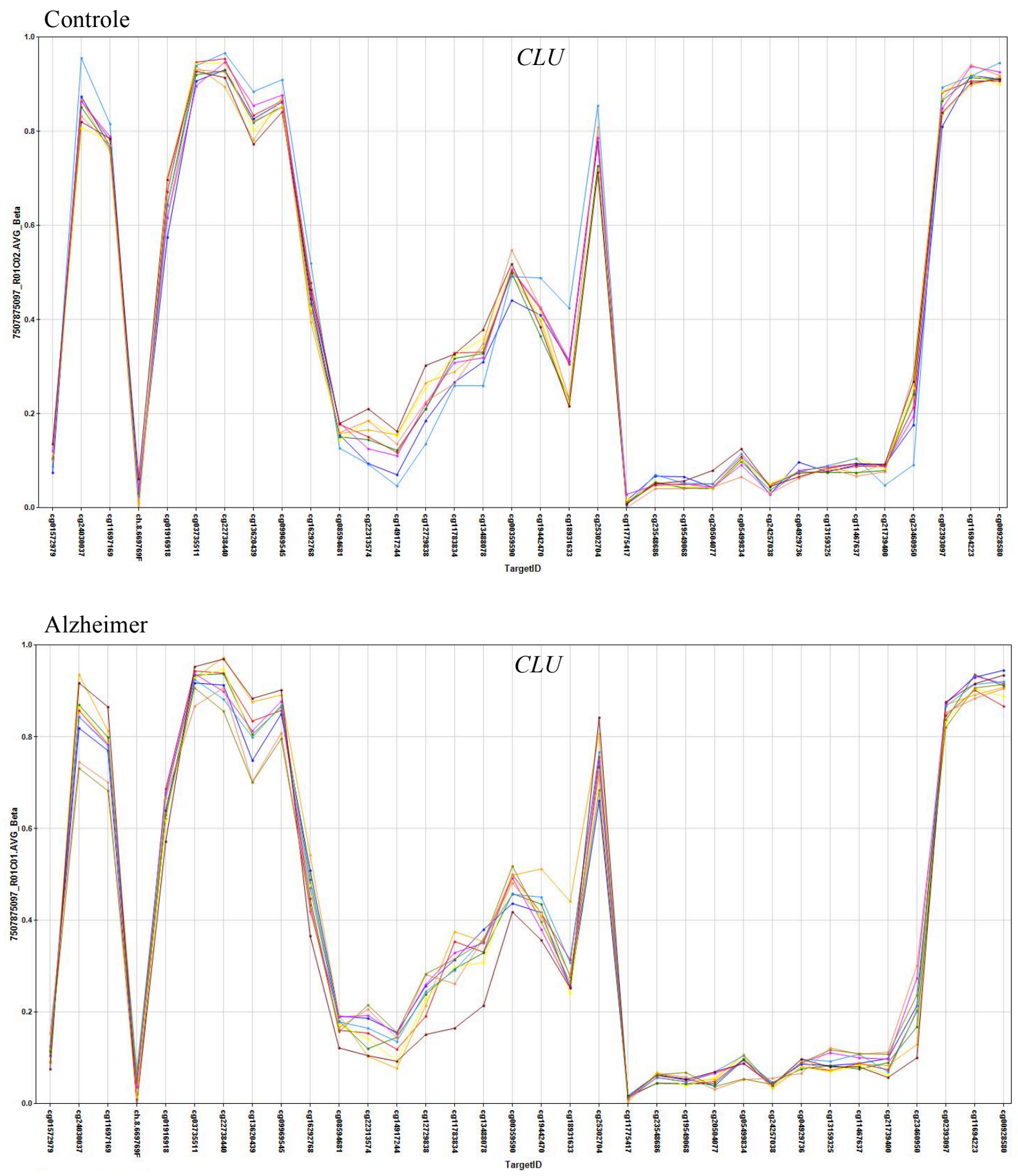

Figura S11. Distribuição dos níveis de metilação ao longo de todos os sítios CpG do gene $C L U$. Cada linha representa um indivíduo e cada ponto equivale a um sítio $\mathrm{CpG}$ com seu respectivo valor de Beta. Imagem extraída do programa computacional Genome Studio. 

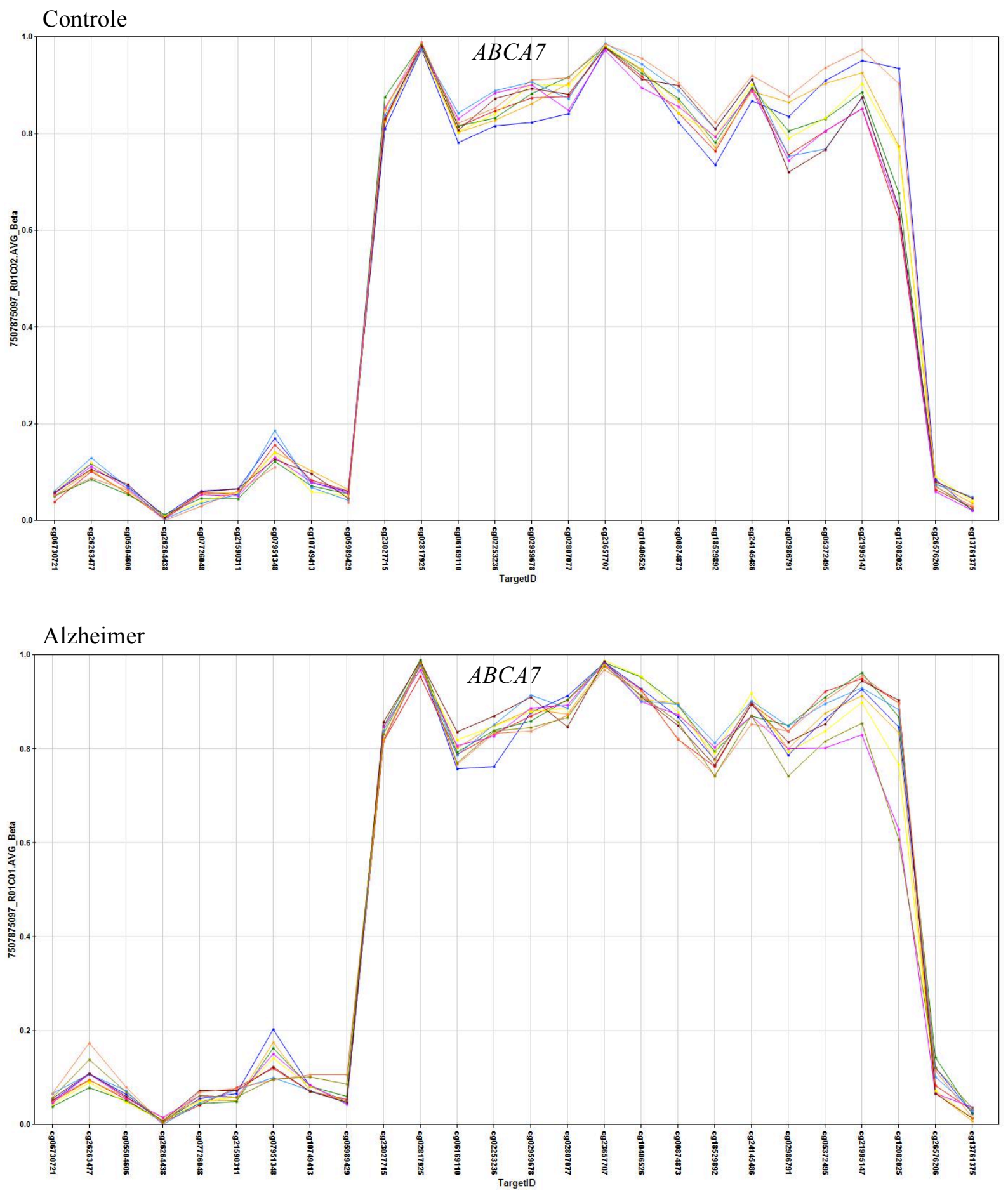

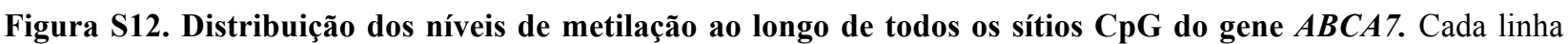
representa um indivíduo e cada ponto equivale a um sítio $\mathrm{CpG}$ com seu respectivo valor de Beta. Imagem extraída do programa computacional Genome Studio. 

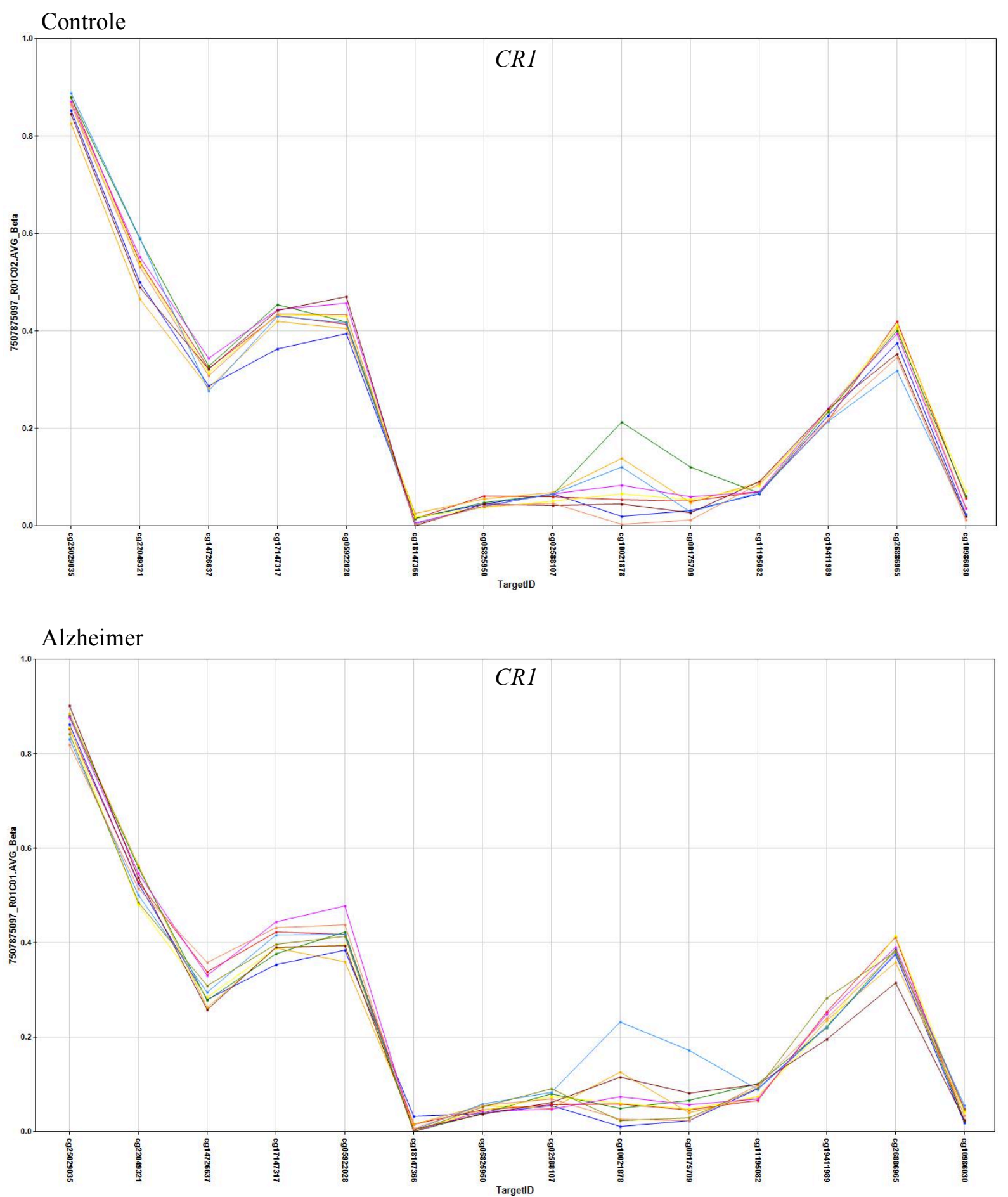

Figura S13. Distribuição dos níveis de metilação ao longo de todos os sítios CpG do gene $C R 1$. Cada linha representa um indivíduo e cada ponto equivale a um sítio $\mathrm{CpG}$ com seu respectivo valor de Beta. Imagem extraída do programa computacional Genome Studio. 

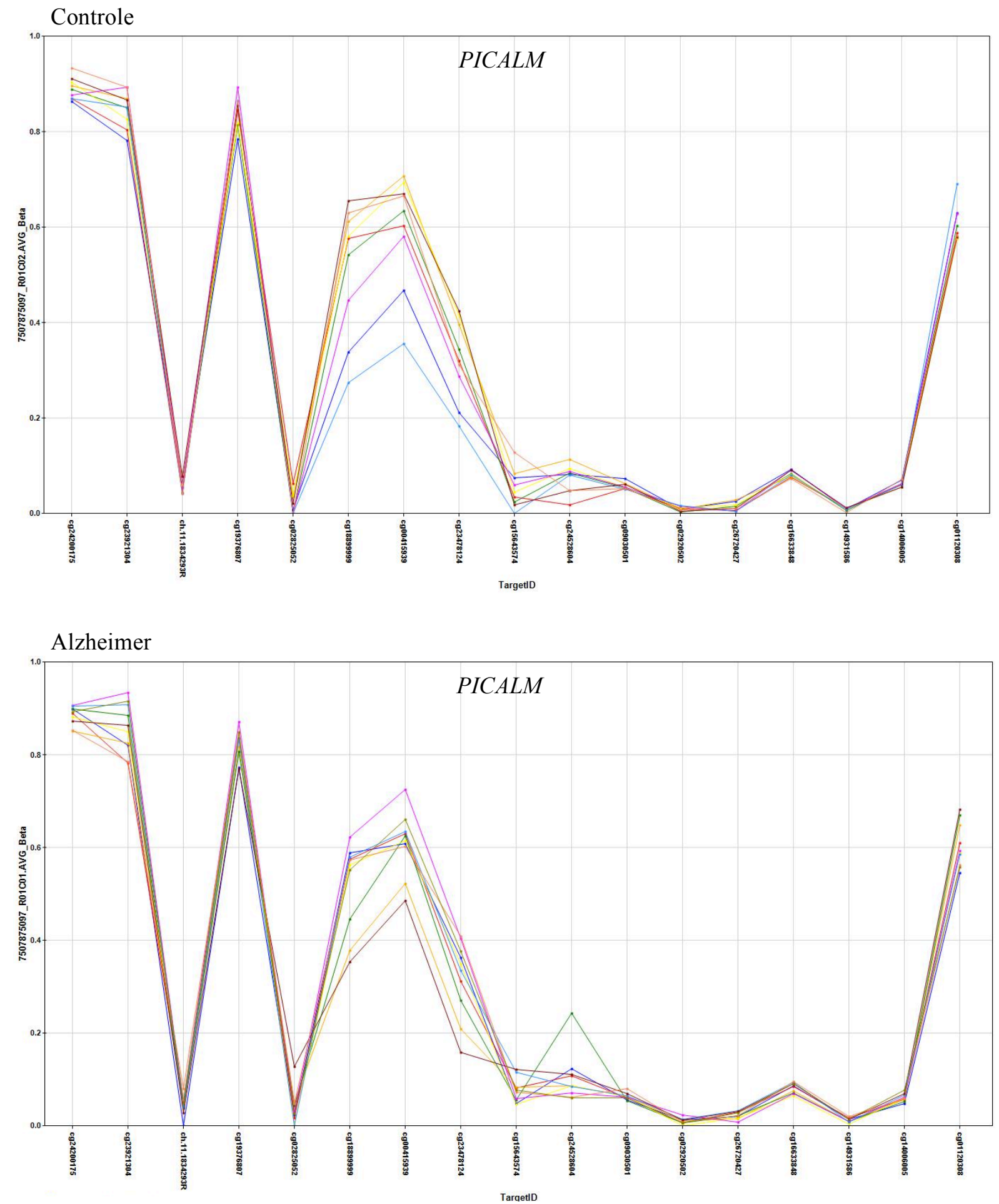

Figura S14. Distribuição dos níveis de metilação ao longo de todos os sítios CpG do gene PICALM. Cada linha representa um indivíduo e cada ponto equivale a um sítio $\mathrm{CpG}$ com seu respectivo valor de Beta. Imagem extraída do programa computacional Genome Studio. 

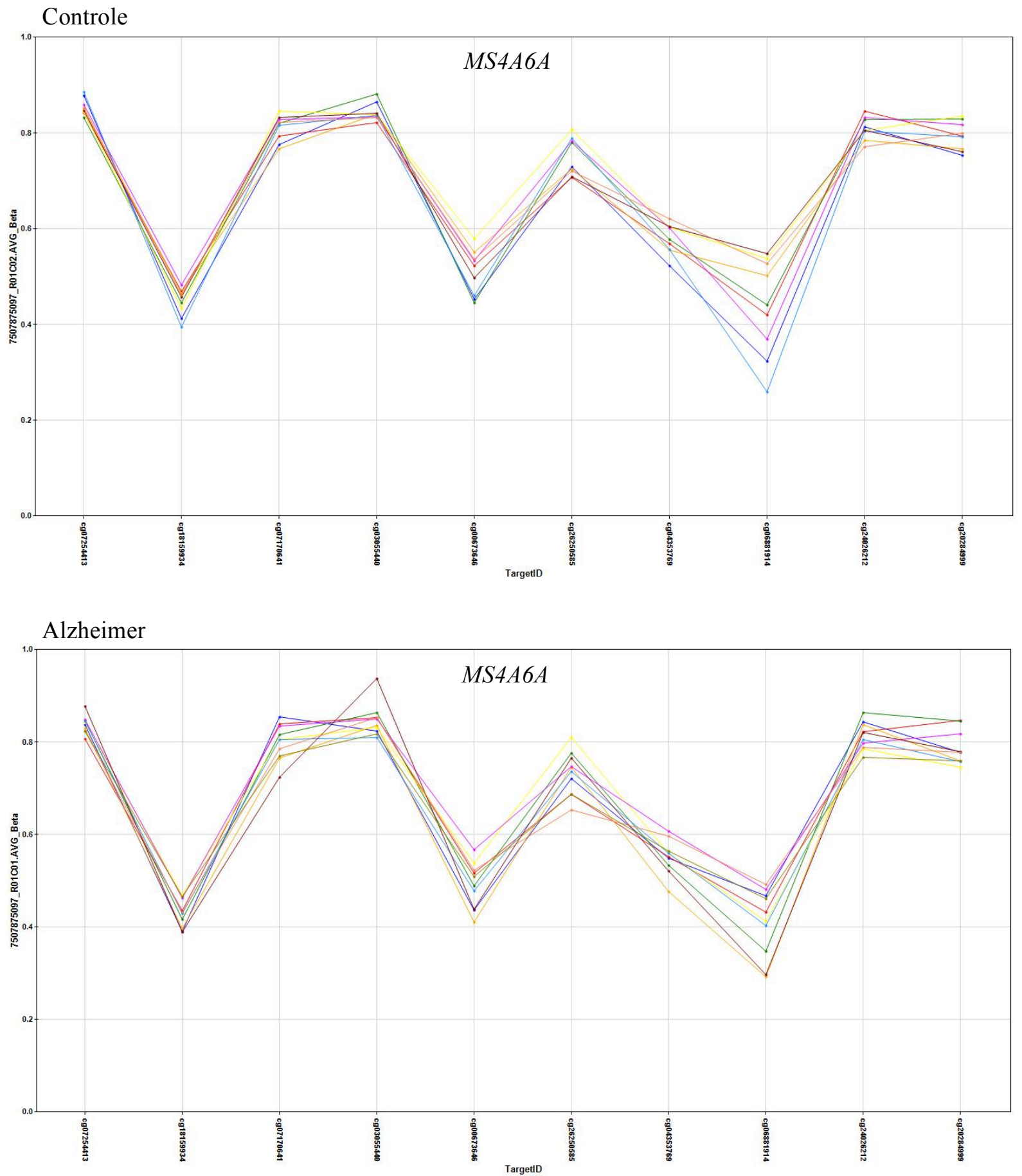

Figura S15. Distribuição dos níveis de metilação ao longo de todos os sítios CpG do gene MS4A6A Cada linha representa um indivíduo e cada ponto equivale a um sítio $\mathrm{CpG}$ com seu respectivo valor de Beta. Imagem extraída do programa computacional Genome Studio. 

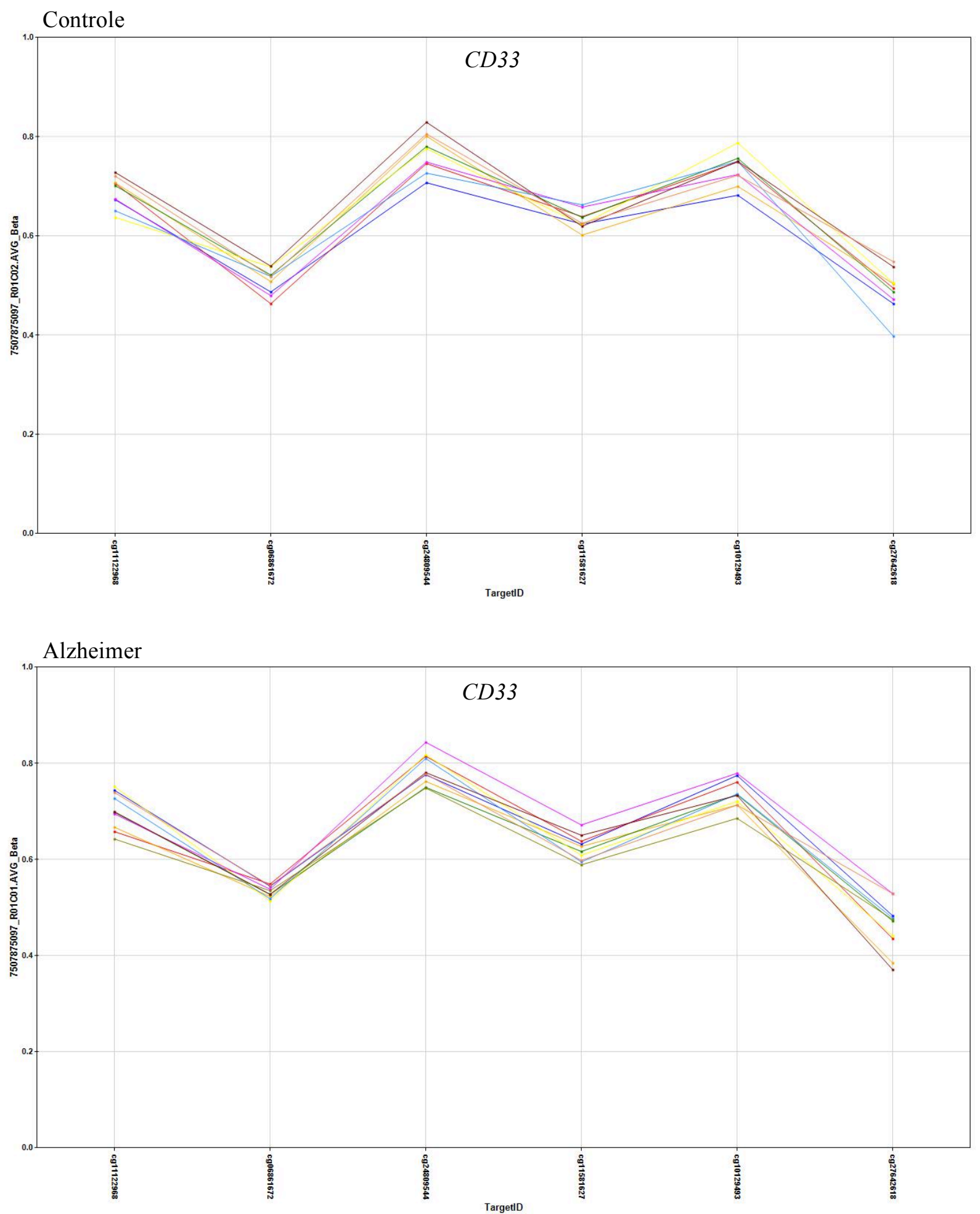

Figura S16. Distribuição dos níveis de metilação ao longo de todos os sítios CpG do gene CD33. Cada linha representa um indivíduo e cada ponto equivale a um sítio $\mathrm{CpG}$ com seu respectivo valor de Beta. Imagem extraída do programa computacional Genome Studio. 

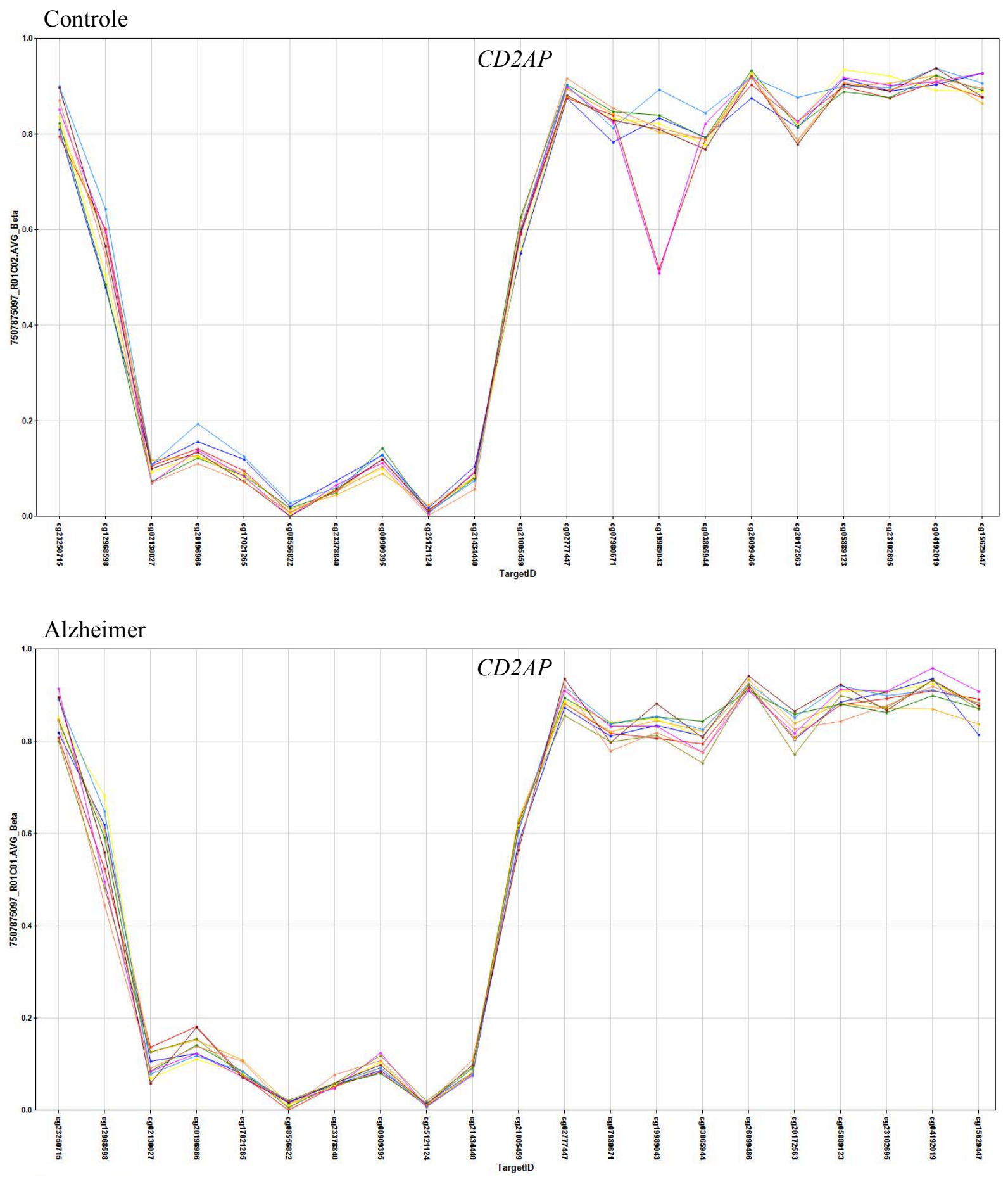

Figura S17. Distribuição dos níveis de metilação ao longo de todos os sítios CpG do gene $C D 2 A P$. Cada linha representa um indivíduo e cada ponto equivale a um sítio $\mathrm{CpG}$ com seu respectivo valor de Beta. Imagem extraída do programa computacional Genome Studio. 
IX. ANEXOS 


\section{ANEXO I}

(Resultados submetidos para publicação na revista BMC Research Notes) 


\section{Do germ-line microduplications in CACNA2D2, CACNA2D3 and CACNA1D}

constitute a predisposing risk factor for Alzheimer's disease?

Darine Villela ${ }^{1}$, David Schlesinger ${ }^{2}$, Claudia K. Suemoto ${ }^{3,6}$, Mayana Zatz ${ }^{1}$, Carlos Augusto Pasqualucci ${ }^{4,6}$, Lea T. Grinberg ${ }^{5,6}$, Carla Rosenberg ${ }^{1}$.

${ }^{1}$ Human Genome and Stem-Cell Research Center, Department of Genetics and Evolutionary Biology, Institute of Biosciences, University of São Paulo, Rua do Matão 277, 05508-090, São Paulo, Brazil

${ }^{2}$ Israel Institute for Teaching and Research Albert Einstein, Av. Albert Einstein 627, 05652-900, São Paulo, Brazil

${ }^{3}$ Discipline of Geriatrics, Department of Internal Medicine, University of São Paulo Medical School, Av. Doutor Arnaldo 455, 01246-000, São Paulo, Brazil.

${ }^{4}$ Department of Pathology, University of São Paulo Medical School, Av. Doutor Arnaldo 455, 01246-000, São Paulo, Brazil.

${ }^{5}$ Memory and Aging Center, Department of Neurology, University of California, San Francisco 675 Nelson Rising Lane, P.O Box 1207, San Francisco - CA - USA 94143

${ }^{6}$ Brazilian Aging Brain Study Group - LIM22, Department of Pathology, University of São Paulo Medical School, Avenida Doutor Arnaldo 455, 01246-000, São Paulo, Brazil.

Keywords: Alzheimer's disease, copy number variations, $\mathrm{CNV}$, array-CGH, $\mathrm{Ca}^{2+}$

Address for correspondence: Carla Rosenberg, PhD, Department of Genetics and Evolutionary Biology, Institute of Biosciences, University of São Paulo, Rua do Matão 277, 05508-090, São Paulo-SP, Brazil. E-mail: carlarosenberg@uol.com.br. 


\begin{abstract}
Dysregulation of calcium $\left(\mathrm{Ca}^{2+}\right)$ homeostasis is now being recognized to be a key step in the pathogenesis of Alzheimer's disease (AD). Data from the literature, in particular the association between $\mathrm{AD}$ and polymorphism that interfere with $\mathrm{Ca}^{2+}$ homeostasis indicates the presence of genetic factors in this process; further, presenilins mutations, which are known to cause the familial form of $\mathrm{AD}$, are involved in the regulation of intracellular $\mathrm{Ca}^{2+}$ stores. Here, we report rare DNA copy number variants affecting genes that encode different subunits of the same type of voltage-gated $\mathrm{Ca}^{2+}$ channels detected in two individuals with late-onset $\mathrm{AD}$. Our findings suggest that alterations in genes implicated in $\mathrm{Ca}^{2+}$ homeostasis may determine susceptibility factors for $\mathrm{AD}$.
\end{abstract}




\section{INTRODUCTION}

In this report, we wish to draw the attention to rare DNA copy number variations (CNVs) that led to partial duplication of genes that encode different subunits of the same type of voltage-gated $\mathrm{Ca}^{2+}$ channels (L-type) identified in two subjects diagnosed post-mortem with late-onset Alzheimer's disease (AD). It's widely known that $\mathrm{Ca}^{2+}$ represents one of the most important second messengers in the brain and plays an essential role in neuronal development, synaptic transmission and plasticity, besides regulating various metabolic pathways (Striessnig et al. 2006). Based on previous observations that intracellular $\mathrm{Ca}^{2+}$ levels are increased in aging neurons, it has recently been suggested that dysregulation of $\mathrm{Ca}^{2+}$ homeostasis could be a key step in the pathogenesis of $\mathrm{AD}$ (Small 2009). The $\beta$-amyloid (A $\beta$ ) protein, present in the extracellular senile plaques, is one of the hallmarks of the disease and has been found to induce $\mathrm{Ca}^{2+}$ influx into neurons, leading to the activation of $\mathrm{Ca}^{2+}$ dependent proteases (caspases and calpains), probably an important step in the breakdown of cytoskeletal proteins in apoptosis (Harris and DeLorenzo 1987). Additionally, one possible mechanism by which $\mathrm{Ca}^{2+}$ influx is stimulated by $\mathrm{A} \beta$ is trough the activation of voltage-gated $\mathrm{Ca}^{2+}$ channels (both L- and $\mathrm{N}$-type) (Sberna et al. 1997). Therefore, the finding of rare duplications affecting subunits of voltage-gated $\mathrm{Ca}^{2+}$ channel in patients with $\mathrm{AD}$ point to a plausible mechanism that could predispose to $\mathrm{AD}$.

\section{METHODS}

The two individuals with late-onset $\mathrm{AD}$ were investigated by the Brain Bank of the Brazilian Aging Brain Study Group (BBBABSG) (Grinberg et al. 2007). Table 1 presents the characterization of these two cases. As a standard protocol for $\mathrm{AD}$ neuropathological diagnosis, the brain was examined macroscopically, and 15 
neurodegenerative disease-related structures were sampled for microscopic evaluation. Neuropathological examinations were carried out using immunohistochemistry following internationally accepted guidelines. CERAD (Consortium to Establish a Registry for Alzheimer's Disease) criteria were used to classify the $\beta$-amyloid neuritic plaque burden, and the distribution of neurofibrillary tangles was classified according to the Braak and Braak staging system (Braak and Braak 1991). The neuropathological diagnosis of $\mathrm{AD}$ is made where cases show at least Braak stage III and CERAD moderate. The usual neuropathological guidelines were used for other dementias and for Parkinson's disease (Grinberg et al. 2007). The subject's clinical and functional statuses were assessed through a knowledgeable informant based on a validated clinical protocol. The protocol included a series of semi-structured scales and questionnaires that cover major functional abilities and were validated for assessment with an informant. BBBABSG's procedures were approved by the local ethics committee and an informed written consent was obtained by the next-of kin (Grinberg et al. 2007).

To identify CNVs we performed comparative genomic hybridization based on microarrays (array-CGH) using a whole-genome platform containing 180.000 oligonucleotides (Oxford Gene Technologies, UK). Briefly, samples were labeled with Cy3- and Cy5-deoxycytidine triphosphates by random priming. Purification, hybridization and washing were carried out as previously reported (Krepischi et al. 2010). Scanned images of the arrays were processed using Feature Extraction software and data were analyzed with the Genomic Workbench software, both from Agilent Technologies. To make CNV calls, we used the Aberration Detection Method 2 statistical algorithm (ADM2) with a sensitivity threshold of 6.7. A genomic segment was considered duplicated or deleted when the $\log _{2}$ ratio of the Test/Reference 
fluorescent intensities of a given region encompassing at least three probes was above 0.3 or below -0.3 , respectively. Detected CNVs were compared to CNV data from oligoarray studies documented in the Database of Genomic Variants (DGV).

\section{RESULTS}

The CNV screening for germ-line mutations in the two individuals with late-onset $\mathrm{AD}$ revealed rare microduplications partially affecting genes that encode different subunits of the same type of voltage-gated $\mathrm{Ca}^{2+}$ channels, the L-type (L-VGCC). Individual A presents a genomic imbalance of $665 \mathrm{~kb}$ at 3p21.1 that incudes, among other genes, CACNA1D and CACNA2D3 (Figure 1A). CACNA1D encodes the subunit $\alpha 1$ (subtype ${ }_{1 D}$ ), which form the ion-conducting pore of the L-VGCC, and $C A C N A 2 D 3$ is responsible for encoding the subunit $\alpha-2 \delta$, that influences the channels' biophysical properties by increasing the current amplitude and regulating the activation and inactivation kinetics of the L-VGCC. On the other hand, the individual B shows a genomic imbalance of $300 \mathrm{~kb}$ at $3 \mathrm{p} 21.31$ that encompass the CACNA2D2 gene, which acts similarly to $C A C N A 2 D 3$, i.e., also encodes the subunit $\alpha-2 \delta$ of the LVGCC (Figure 1B). Both duplications have intragenic breakpoints; depending on the resulting structure of the rearrangement, the partial gene duplications can result in loss of function of the genes involved. To exclude that these rare CNVs (rare defined as frequency $<0.1 \%$ of population, based on DGV) represent common variants in the Brazilian population, we compile CNV data from more than 1,300 individuals studied by array-CGH in our laboratory for reasons other than dementia, such as cancer predisposition and intellectual deficiency. The rare CNVs documented in this study were never detected in any of these subjects. 


\section{DISCUSSION}

CNVs are recognized to be a prevalent form of common genetic variation and represent a substantial proportion of total genetic variability in human population. The functional impact of CNVs has been demonstrated at all biological levels, from cellular effects on gene expression to their association with several types of complex traits and genetic diseases (Stankiewicz and Lupski 2010). To date, copy number changes in genes encoding calcium-signaling molecules have been associated especially with neuronal development disorders, such as autism (Rosenfeld et al. 2010), psychiatric diseases (Lee et al. 2012), and amyotrophic lateral sclerosis (Wain et al. 2009). However, previous works suggest that genetic factors could also play a role in the dysregulation of $\mathrm{Ca}^{2+}$ homeostasis in $\mathrm{AD}$. Dreses-Werringloer and colleagues demonstrated that a polymorphism in CALHM1 $\mathrm{CCa}^{2+}$ homeostasis modulator-1) is significantly associated with $\mathrm{AD}$ in case-control studies. Based on its sequence similarity to the ionotropic glutamate receptor NMDA, it has been proposed that this gene encodes a glycoprotein that is a cerebral $\mathrm{Ca}^{2+}$ channel component; and the expression of its polymorphic variant increases $A \beta$ levels by reducing cytosolic $\mathrm{Ca}^{2+}$ concentration (Dreses-Werringloer et al. 2008). Also, presenilins mutations, which are known to cause the familial form of $\mathrm{AD}$, have been found to increase the release of intracellular $\mathrm{Ca}^{2+}$ from inositol 1,4,5-trisphosphate (IP3) channels (Tu et al. 2006). Our study, though, is the first to report genomic imbalances in genes that are known to encode important calcium-signaling molecules, and link those CNVs to late-onset $\mathrm{AD}$. Considering the importance of L-VGCC in the central nervous system and $\mathrm{Ca}^{2+}$ being such an important regulator of synaptic plasticity, we could suppose that a disruption in $C A C N A 1 D, C A C N A 2 D 3$ and $C A C N A 2 D 3$ caused by CNVs may 
lead to a dysregulation in $\mathrm{Ca}^{2+}$ homeostasis and contribute to the pathogenesis of $\mathrm{AD}$. Yet, the crucial question of whether the microduplications showed in this study constitutes a predisposing risk factor for $\mathrm{AD}$ can only be answered by similar investigations, which we hope will be stimulated by this report.

In summary, our findings point out to CNVs that disrupts important genes for calcium signaling and suggest that those rare genomic imbalances may be relevant as potential disease-susceptibility variants for $\mathrm{AD}$.

\section{ACKNOWLEDGEMENTS}

This work was supported by FAPESP grants CR and CEPID-FAPESP (2009/00898-

1; 2013/08028-1), and DV was supported by FAPESP PhD fellowship (2010/15503-

0). We thank the Brazilian Aging Brain Study Group for providing DNA samples.

Conflict of interest: The authors have no conflict of interest to declare 


\section{REFERENCES}

Braak H.and Braak E. 1991. Neuropathological stageing of Alzheimer-related changes. Acta neuropathologica. 82, 239-59.

Dreses-Werringloer U., Lambert J. C., Vingtdeux V., Zhao H., Vais H., Siebert A., Jain A., Koppel J., Rovelet-Lecrux A., Hannequin D., Pasquier F., Galimberti D., Scarpini E., Mann D., Lendon C., Campion D., Amouyel P., Davies P., Foskett J. K., Campagne F.and Marambaud P. 2008. A polymorphism in CALHM1 influences Ca2+ homeostasis, Abeta levels, and Alzheimer's disease risk. Cell. 133, 1149-61.

Grinberg L. T., Ferretti R. E., Farfel J. M., Leite R., Pasqualucci C. A., Rosemberg S., Nitrini R., Saldiva P. H.and Filho W. J. 2007. Brain bank of the Brazilian aging brain study group - a milestone reached and more than 1,600 collected brains. Cell and tissue banking. 8, 151-62.

Harris J. K.and DeLorenzo R. J. 1987. Calcium and neuronal cytoskeletal proteins: alterations with aging. Neurobiol Aging. 8, 359-61.

Krepischi A. C., Knijnenburg J., Bertola D. R., Kim C. A., Pearson P. L., Bijlsma E., Szuhai K., Kok F., Vianna-Morgante A. M.and Rosenberg C. 2010. Two distinct regions in 2q24.2-q24.3 associated with idiopathic epilepsy. Epilepsia. $\mathbf{5 1}, 2457-60$.

Lee K. W., Woon P. S., Teo Y. Y.and Sim K. 2012. Genome wide association studies (GWAS) and copy number variation (CNV) studies of the major psychoses: what have we learnt? Neurosci Biobehav Rev. 36, 556-71.

Rosenfeld J. A., Ballif B. C., Torchia B. S., Sahoo T., Ravnan J. B., Schultz R., Lamb A., Bejjani B. A.and Shaffer L. G. 2010. Copy number variations associated 
with autism spectrum disorders contribute to a spectrum of neurodevelopmental disorders. Genet Med. 12, 694-702.

Sberna G., Saez-Valero J., Beyreuther K., Masters C. L.and Small D. H. 1997. The amyloid beta-protein of Alzheimer's disease increases acetylcholinesterase expression by increasing intracellular calcium in embryonal carcinoma P19 cells. J Neurochem. 69, 1177-84.

Small D. H. 2009. Dysregulation of calcium homeostasis in Alzheimer's disease. Neurochem Res. 34, 1824-9.

Stankiewicz P.and Lupski J. R. 2010. Structural variation in the human genome and its role in disease. Annu Rev Med. 61, 437-55.

Striessnig J., Koschak A., Sinnegger-Brauns M. J., Hetzenauer A., Nguyen N. K., Busquet P., Pelster G.and Singewald N. 2006. Role of voltage-gated L-type Ca2+ channel isoforms for brain function. Biochem Soc Trans. 34, 903-9.

Tu H., Nelson O., Bezprozvanny A., Wang Z., Lee S. F., Hao Y. H., Serneels L., De Strooper B., Yu G.and Bezprozvanny I. 2006. Presenilins form ER Ca2+ leak channels, a function disrupted by familial Alzheimer's disease-linked mutations. Cell. 126, 981-93.

Wain L. V., Pedroso I., Landers J. E., Breen G., Shaw C. E., Leigh P. N., Brown R. H., Tobin M. D.and Al-Chalabi A. 2009. The role of copy number variation in susceptibility to amyotrophic lateral sclerosis: genome-wide association study and comparison with published loci. PLoS One. 4, e8175. 


\section{FIGURE LEGEND}

Figure 1. Rare germline copy number variations (CNVs) detected in two individuals with late-onset Alzheimer's disease. Part (A) shows the microduplication at $3 \mathrm{p} 21.1$ of $665 \mathrm{~kb}$ containing the CACNA1D and CACNA2D3 genes that corresponds to individual A. Part (B) shows the microduplication at 3 p21.31 of $300 \mathrm{~kb}$ containing the CACNA2D2 gene that corresponds to individual B. Top panels from A and B exhibit the array-CGH profiles of the chromosome regions (images based on the Genomic Workbench software) containing the selected CNVs. Bottom panels from $\mathrm{A}$ and $\mathrm{B}$ show the $\mathrm{CNV}$ position in the chromosome (small vertical bars in the ideograms) and the corresponding genomic segments. The region covered by the $\mathrm{CNV}$ and the genomic imbalance loci reported in the general population are indicated by blue (gain) and red (loss) bars in the Database of Genomic Variants (DGV) (image derived from the DGV, freeze October 2013). 
(A)

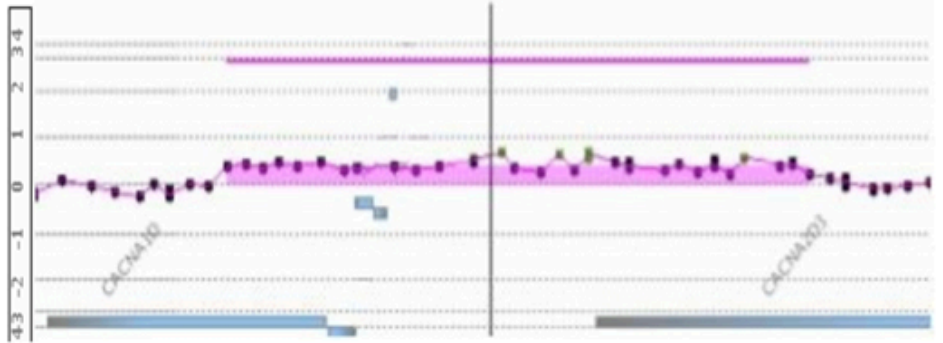

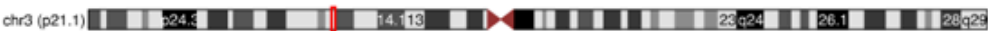

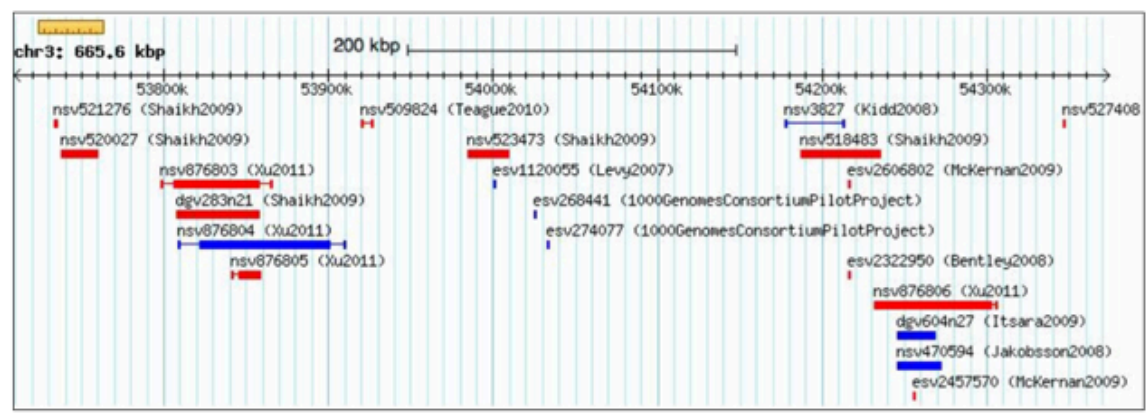

(B)

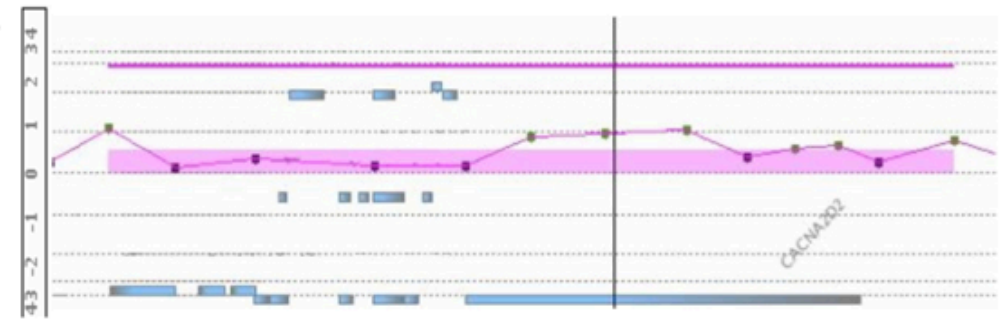

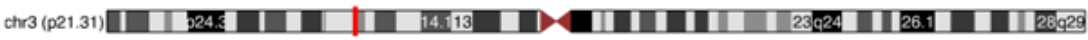

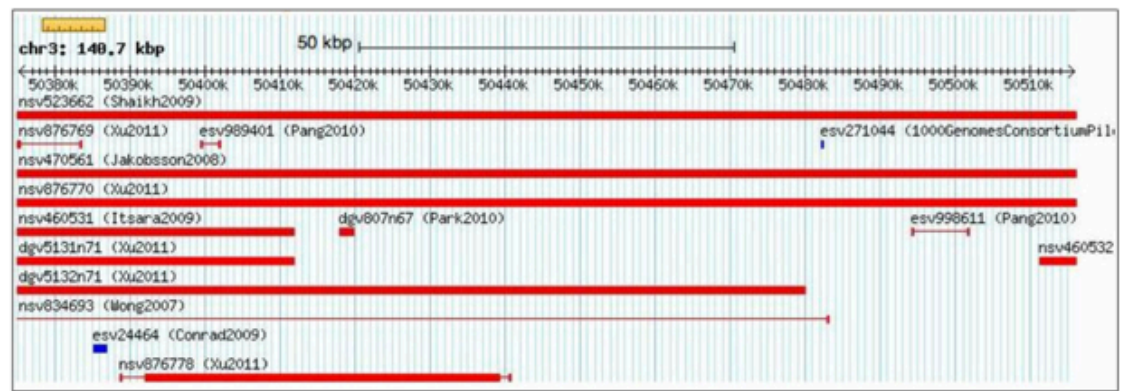


Additional files provided with this submission:

Additional file 1: Table 1 paper Calcium and DA.docx, 16K

http://www.biomedcentral.com/imedia/1405382003120625/supp1.docx 


\section{ANEXO II}

(Resultados aceitos para publicação na revista Journal of Genetics) 


\section{Journal of Genetics}

\section{A microdeletion in Alzheimer's disease disrupts NAMPT gene --Manuscript Draft--}

\begin{tabular}{|c|c|}
\hline Manuscript Number: & JGEN-D-13-00241R1 \\
\hline Full Title: & A microdeletion in Alzheimer's disease disrupts NAMPT gene \\
\hline Article Type: & Research Note \\
\hline Keywords: & Alzheimer's disease; copy number variations; CNVs; array-CGH; NAMPT \\
\hline Corresponding Author: & $\begin{array}{l}\text { Carla Rosenberg } \\
\text { BRAZIL }\end{array}$ \\
\hline \multicolumn{2}{|c|}{$\begin{array}{l}\text { Corresponding Author Secondary } \\
\text { Information: }\end{array}$} \\
\hline \multicolumn{2}{|c|}{ Corresponding Author's Institution: } \\
\hline \multicolumn{2}{|c|}{$\begin{array}{l}\text { Corresponding Author's Secondary } \\
\text { Institution: }\end{array}$} \\
\hline First Author: & Darine Villela \\
\hline \multicolumn{2}{|c|}{ First Author Secondary Information: } \\
\hline \multirow[t]{5}{*}{ Order of Authors: } & Darine Villela \\
\hline & David Schlesinger \\
\hline & Claudia Suemoto \\
\hline & Lea Grinberg \\
\hline & Carla Rosenberg \\
\hline \multicolumn{2}{|c|}{ Order of Authors Secondary Information: } \\
\hline Abstract: & $\begin{array}{l}\text { DNA copy number variations (CNV) are recognized to be a prevalent form of common } \\
\text { genetic variation in the human genome and its role in normal development and disease } \\
\text { has been demonstrated through its impact on gene expression and protein structure } \\
\text { (Stankiewicz and Lupski 2010). Here, we report on a subject with late-onset of } \\
\text { Alzheimer's disease (AD) a rare CNV that disrupts NAMPT, which encodes an } \\
\text { important enzyme that mediates nicotinamide adenine dinucleotide (NAD) } \\
\text { biosynthesis. Recently, an interesting study showed that overexpression of the NAD- } \\
\text { dependent deacetylase sirtuin-1 (SIRT1) reduces the production of A } \beta \text { and plaques in } \\
\text { the brain of AD mice (Donmez et al. 2010); disruption of NAMPT, therefore, is a } \\
\text { predictable mechanism of increasing the production of A } \mathrm{A} \text { and plaques. }\end{array}$ \\
\hline Response to Reviewers: & $\begin{array}{l}\text { To Dr Gracy Rani } \\
\text { Editor-Assisstant } \\
\text { Journal of Genetics } \\
\text { Ref.: Ms. No. JGEN-D-13-00241 } \\
\text { Dear Dr Rani } \\
\text { Please find a revised version of the manuscript "A microdeletion in Alzheimer's disease } \\
\text { disrupts NAMPT gene" that we are resubmitting for publication in the Journal of } \\
\text { Genetics. Below please find the response to the reviewers. } \\
\text { Reviewer \#1 } \\
\text { Copy number variations (CNV) can result from inheritance as well as de novo } \\
\text { mutations. In this MS only a single subject has been examined, it is thus difficult to } \\
\text { comment about the origin/source of this microdeletion. } \\
\text { However, the deletion is observed in an important gene involved in NAD biosynthesis } \\
\text { and may contribute to plaque formation. Thus, it is a good indication that NAMPT may }\end{array}$ \\
\hline
\end{tabular}


be associated with $A D$. Further validation of the association of this gene is needed in more number of patients. Moreover the authors have not done any biological validation of this novel deletion in the function of NAMPT protein.

In my opinion, this finding can be recommended to be published as a short report/short note in "Journal of Genetics".

The Reviewer pointed out correctly that this is a single observation and further studies are needed to confirm the relevance of this gene for Alzheimer's disease (AD), which we hope will be stimulated by this report. We added to the manuscript not only a comparison to the large sample studied in DGV but also to the $>1300$ individuals already analyzed by array-CGH in our laboratory for reasons others than $A D$. This $C N V$ has never been observed, confirming that it does not represent a common variant of the Brazilian population. Because of the limited amount of data, the paper is being submitted as a research note.

Reviewer \#2

This manuscript focuses on the association of a novel DNA copy number variation with late onset Alzheimer's disease. Though the observations reported here are interesting, there are some minor issues with the manuscripts. First of all, this report is from a single patient. Was the presence of this CNV validated using some other method? Could the authors comment on the frequency of this CNV? Also it would benefit the audience if a better description of the methodology used to identify CNVs is added to the manuscript. I am also curious to know what other CNVs/SNPs was observed in this patient along with the reported CNV in NAMPT gene.

The CNV was indeed observed in a single patient among more than 1300 individuals studied in our laboratory for different reasons. Therefore, the frequency of the CNV is very low not only in the population documented in DGV but also among Brazilian individuals. The CNV was confirmed by reverse labeled hybridization, as showed in the figure enclosed for the Reviewer and also described in the method, which is now more detailed. This approach has been proved to be very consistent during the experimental period of array-CGH in our laboratory, when the finding of the first 300 patients were all confirmed by FISH (Rosenberg C et al. Hum.Genet. 2005; 116:390. Krepischi-Santos AC et al Cytogenet.Genome Res. 2006; 115:254). A table with all CNVs of the patient was included.

Minor issues: Add the full name of the NAMPT gene (2nd page,15th line).

It was added.

The sentence on 4th page,18th line ('However, there are no reports..') is confusing. It would be good if its reformatted.

It was reformatted.

Reviewer \#3

This is an interesting paper showing a deletion in NAMPT in the brain of an AD patient. Of course, one can not assume cause and effect with an $\mathrm{N}=1$, but the deletion is provocative and may stimulate a more comprehensive analysis of a link between NAMPT and late onset AD. 
A

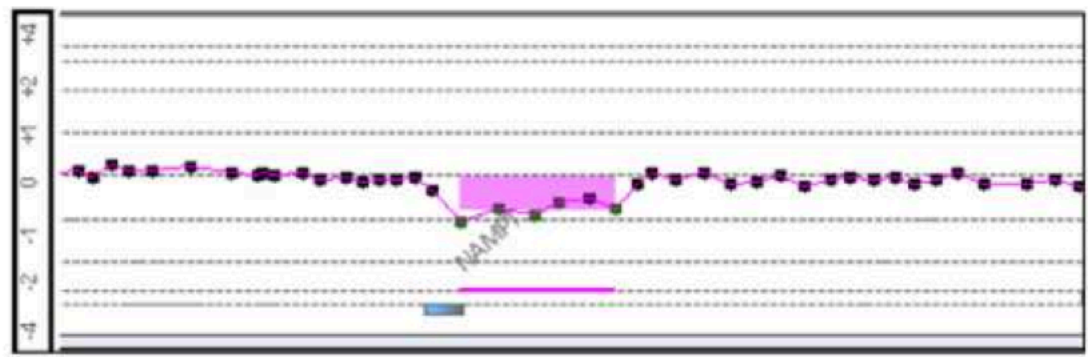

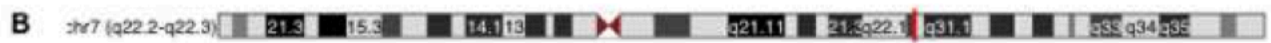

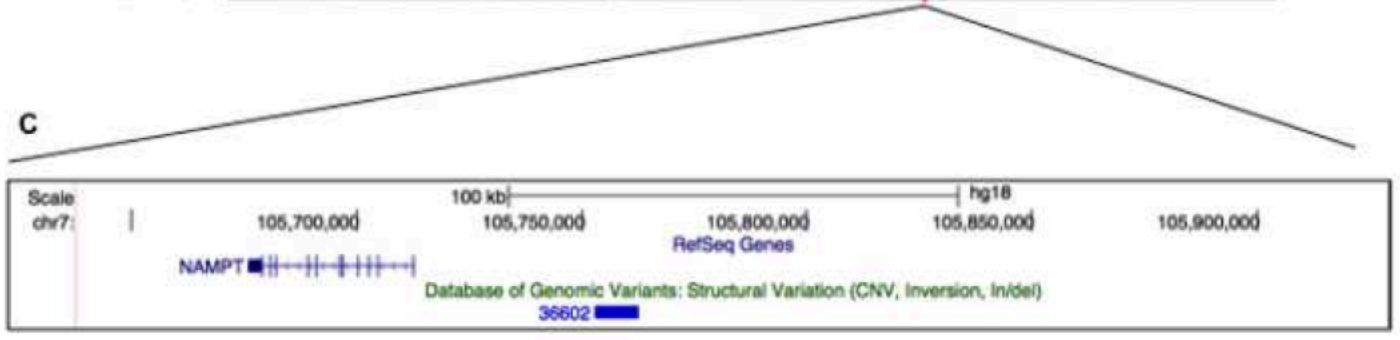




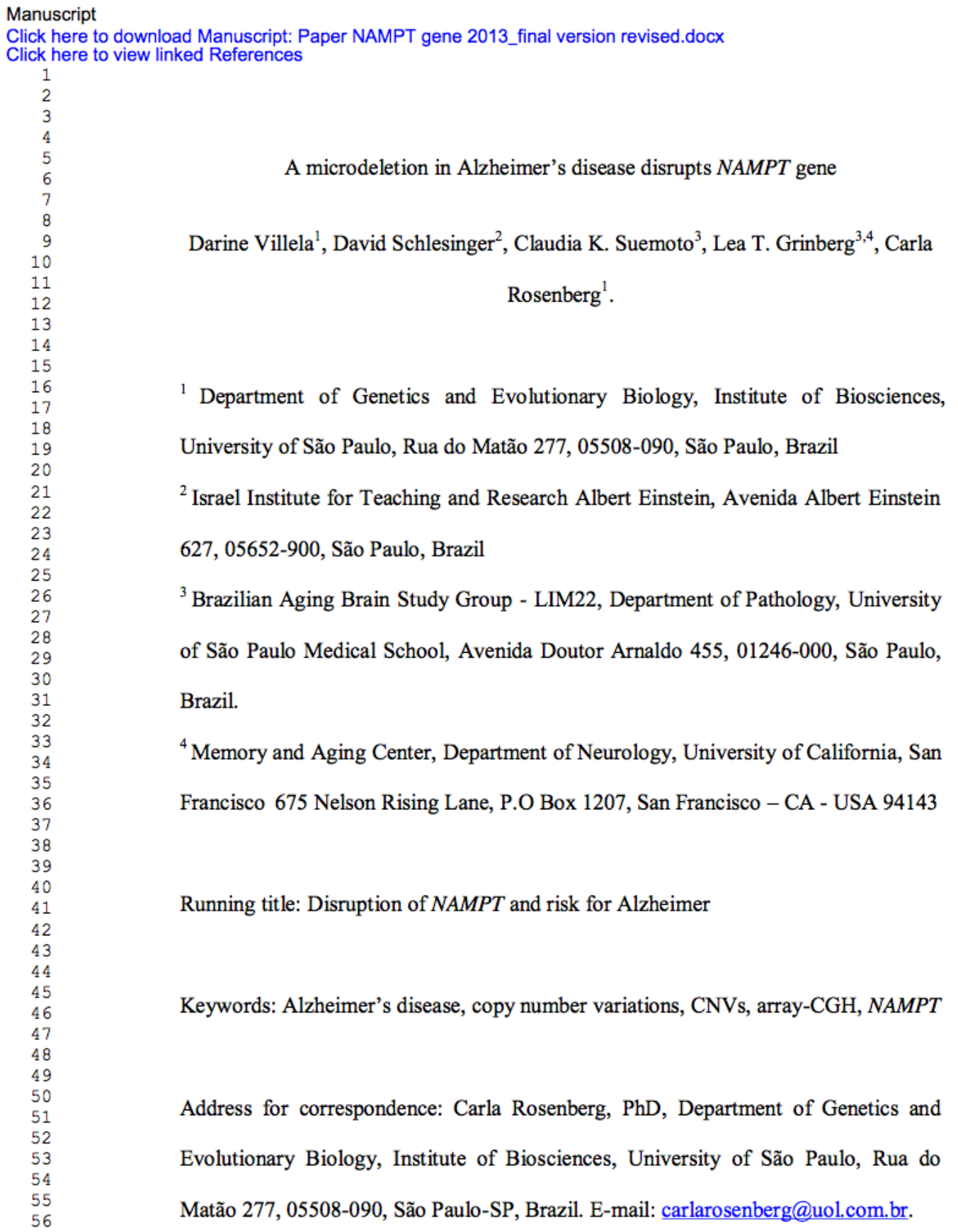

Darine Villela ${ }^{1}$, David Schlesinger ${ }^{2}$, Claudia K. Suemoto ${ }^{3}$, Lea T. Grinberg ${ }^{3,4}$, Carla Rosenberg ${ }^{1}$.

${ }^{1}$ Department of Genetics and Evolutionary Biology, Institute of Biosciences, University of São Paulo, Rua do Matão 277, 05508-090, São Paulo, Brazil

${ }^{2}$ Israel Institute for Teaching and Research Albert Einstein, Avenida Albert Einstein 627, 05652-900, São Paulo, Brazil

${ }^{3}$ Brazilian Aging Brain Study Group - LIM22, Department of Pathology, University of São Paulo Medical School, Avenida Doutor Arnaldo 455, 01246-000, São Paulo, Brazil.

${ }^{4}$ Memory and Aging Center, Department of Neurology, University of California, San Francisco 675 Nelson Rising Lane, P.O Box 1207, San Francisco - CA - USA 94143

Running title: Disruption of NAMPT and risk for Alzheimer

Keywords: Alzheimer's disease, copy number variations, CNVs, array-CGH, NAMPT

Address for correspondence: Carla Rosenberg, $\mathrm{PhD}$, Department of Genetics and Evolutionary Biology, Institute of Biosciences, University of São Paulo, Rua do Matão 277, 05508-090, São Paulo-SP, Brazil. E-mail: carlarosenberg@uol.com.br. 
DNA copy number variations (CNVs) are recognized to be a prevalent form of common genetic variation in the human genome and its role in normal development and disease has been demonstrated through its impact on gene expression and protein structure (Stankiewicz and Lupski 2010). Here, we report on a subject with late-onset of Alzheimer's disease (AD) a rare $\mathrm{CNV}$ that disrupts the nicotinamide phosphoribosyltransferase (NAMPT) gene, which encodes an important enzyme that mediates nicotinamide adenine dinucleotide (NAD) biosynthesis. Recently, an interesting study showed that overexpression of the NAD-dependent deacetylase sirtuin-1 (SIRT1) reduces the production of $\mathrm{A} \beta$ and plaques in the brain of $\mathrm{AD}$ mice (Donmez et al. 2010); disruption of NAMPT, therefore, is a predictable mechanism of increasing the production of $A \beta$ and plaques.

The subject was an 83-year-old woman, Caucasian, one year of schooling, investigated by the Brain Bank of the Brazilian Aging Brain Study Group (BBBABSG) (Grinberg et al. 2007) with a neuropathological diagnosis of AD (Braak stage 3; Consortium to Establish a Registry in $\mathrm{AD}$ - CERAD - moderate, and moderate likelihood that the dementia was caused by $\mathrm{AD}$ according to the NIAReagan criteria). After a day of hospitalization due to chest pain and dyspnea, she died because of an acute myocardial infarction. The brain was examined macroscopically, and 15 neurodegenerative disease-related structures were sampled for microscopic examination according to standard protocol. Neuropathological examinations were carried out using immunohistochemistry following internationally accepted guidelines. CERAD criteria were used to classify the $\beta$-amyloid neuritic 
plaque burden and the distribution of neurofibrillary tangles was classified according to the Braak and Braak staging system (Braak and Braak 1991). The neuropathological diagnosis of $\mathrm{AD}$ is made where cases show at least Braak stage III and CERAD moderate. The usual neuropathological guidelines were used for other dementias and for Parkinson's disease (Grinberg et al. 2007). The subject's clinical and functional statuses were assessed through a knowledgeable informant based on a validated clinical protocol. The protocol included a series of semi-structured scales and questionnaires that cover major functional abilities and were validated for assessment with an informant. BBBABSG's procedures were approved by the local ethics committee and an informed written consent was obtained by the next-of kin (Grinberg et al. 2007).

To identify new candidate genes, we investigated constitutive CNVs by oligonucleotide comparative genomic hybridization based on microarray (arrayCGH) using a $180 \mathrm{~K}$ whole-genome platform (Oxford Gene Technologies, UK), as previously described (Krepischi et al. 2012). Briefly, samples were labeled with Cy3and Cy5-deoxycytidine triphosphates by random priming. Purification, hybridization and washing were carried out as recommended by the manufacturer. Scanned images of the arrays were processed using Feature Extraction software and data were analyzed with the Genomic Workbench software, both from Agilent Technologies. To identify CNVs, we used the Aberration Detection Method 2 statistical algorithm (ADM2) with a sensitivity threshold of 6.7. A genomic segment was considered duplicated or deleted when the $\log _{2}$ ratio of the Test/Reference fluorescent intensities of a given region encompassing at least three probes was above 0.3 or below -0.3 , 
respectively. All hybridizations were gender-matched and processed in reverselabeling duplicates; CNVs that were not detected in both dye-swap experiments of the same sample were excluded from the analysis.

The array-CGH analysis of peripheral blood DNA from this woman with late-onset $\mathrm{AD}$ revealed six CNVs (Table 1). While some of them contained no gene or were commonly variable in copy number in the population, an identified heterozygous 146 $\mathrm{Kb}$ deletion at $7 \mathrm{q} 22.2$ disrupting the NAMPT gene has not been reported on the Database of Genomic Variants (DGV) (Figure 1), a database that compiles published studies on CNVs observed among over 11,000 normal individuals (http://projects.tcag.ca/variation). Furthermore, we have never observed this variant in any of the $>1,300$ individuals studied by array-CGH in our laboratory for reasons others than dementia, such as cancer predisposition and intellectual deficiency, therefore excluding that this $\mathrm{CNV}$ represents a polymorphism of the Brazilian population. Table 1 shows the description of all CNVs identified in the subject of this report.

By affecting dosage-sensitive genes or genes that are crucial for normal development or maintenance, rare CNVs have also been implicated in neurodevelopment and neurodegenerative disorders such as autism spectrum disorder, mental deficiency, schizophrenia, depression, and Parkinson's disease (Lee and Lupski 2006). However, there are no whole-genome investigations of rare CNVs in patients with late-onset $\mathrm{AD}$; copy number investigations of targeted genes have been reported for $A P O E$ and $C R 1$, genes whose roles in $\mathrm{AD}$ are well established. So far only common CNVs were associated to the disease, always with low penetrance (Heinzen et al. 2010; Shaw et 
al. 2011). We showed in a subject with late-onset $\mathrm{AD}$ a never previously reported genomic imbalance that disrupts $N A M P T$, which encodes a key enzyme of NAD biosynthesis. The functional connection between NAMPT-mediated NAD biosynthesis and SIRT1 has been demonstrated in different cell types, showing that this pathway regulates important biological events including aging (Imai 2011). Donmez and colleagues showed that the overexpression of NAD-dependent deacetylase SIRT1 prevents one of the hallmarks of $\mathrm{AD}$ : $\mathrm{A} \beta$ amyloid deposition (Donmez et al. 2010). SIRT1 decreases the production of A $\beta$ amyloid by deacetylating the retinoic acid receptor $\beta$ and thereby up-regulating ADAM10, a major component of $\alpha$-secretase. Additionally, other studies demonstrated that SIRT1 promotes degradation of phosphorylated tau by deacetylating it and prevents taumediated neurodegeneration besides regulating memory and synaptic plasticity (Michan et al. 2010; Min et al. 2010). Altogether, these evidences reveal NAMPT as a strong and predictable candidate gene to confer differential risk to $\mathrm{AD}$. The crucial question of whether alterations in the NAMPT gene constitute a predisposition factor for $\mathrm{AD}$ can only be answered by similar investigations in other cohorts, which we hope will be stimulated by this report.

In summary, our result shows the existence of a novel candidate susceptibility gene for late-onset $\mathrm{AD}$ and highlights the importance of rare CNVs as potential diseasesusceptibility variants for the disease.

\section{ACKNOWLEDGEMENTS}


This work was supported by FAPESP grant CR (2009/00898-1) and DV was supported by FAPESP $\mathrm{PhD}$ fellowship (2010/15503-0). We thank the Brazilian Aging Brain Study Group for providing DNA samples.

Conflict of interest: The authors have no conflict of interest to declare 


\section{REFERENCES}

Braak H.and Braak E. 1991. Neuropathological stageing of Alzheimer-related changes. Acta neuropathologica. 82, 239-59.

Donmez G., Wang D., Cohen D. E.and Guarente L. 2010. SIRT1 suppresses betaamyloid production by activating the alpha-secretase gene ADAM10. Cell. $142,320-32$.

Grinberg L. T., Ferretti R. E., Farfel J. M., Leite R., Pasqualucci C. A., Rosemberg S., Nitrini R., Saldiva P. H.and Filho W. J. 2007. Brain bank of the Brazilian aging brain study group - a milestone reached and more than 1,600 collected brains. Cell and tissue banking. 8, 151-62.

Heinzen E. L., Need A. C., Hayden K. M., Chiba-Falek O., Roses A. D., Strittmatter W. J., Burke J. R., Hulette C. M., Welsh-Bohmer K. A.and Goldstein D. B. 2010. Genome-wide scan of copy number variation in late-onset Alzheimer's disease. J Alzheimers Dis. 19, 69-77.

Imai S. 2011. Dissecting systemic control of metabolism and aging in the NAD World: the importance of SIRT1 and NAMPT-mediated NAD biosynthesis. FEBS letters. 585, 1657-62.

Krepischi A. C., Achatz M. I., Santos E. M., Costa S. S., Lisboa B. C., Brentani H., Santos T. M., Goncalves A., Nobrega A. F., Pearson P. L., Vianna-Morgante A. M., Carraro D. M., Brentani R. R.and Rosenberg C. 2012. Germline DNA copy number variation in familial and early-onset breast cancer. Breast Cancer Res. 14, R24. 
Lee J. A.and Lupski J. R. 2006. Genomic rearrangements and gene copy-number alterations as a cause of nervous system disorders. Neuron. 52, 103-21.

Michan S., Li Y., Chou M. M., Parrella E., Ge H., Long J. M., Allard J. S., Lewis K., Miller M., Xu W., Mervis R. F., Chen J., Guerin K. I., Smith L. E., McBurney M. W., Sinclair D. A., Baudry M., de Cabo R.and Longo V. D. 2010. SIRT1 is essential for normal cognitive function and synaptic plasticity. The Journal of neuroscience : the official journal of the Society for Neuroscience. 30, 9695-707.

Min S. W., Cho S. H., Zhou Y., Schroeder S., Haroutunian V., Seeley W. W., Huang E. J., Shen Y., Masliah E., Mukherjee C., Meyers D., Cole P. A., Ott M.and Gan L. 2010. Acetylation of tau inhibits its degradation and contributes to tauopathy. Neuron. 67, 953-66.

Shaw C. A., Li Y., Wiszniewska J., Chasse S., Zaidi S. N., Jin W., Dawson B., Wilhelmsen K., Lupski J. R., Belmont J. W., Doody R. S.and Szigeti K. 2011. Olfactory copy number association with age at onset of Alzheimer disease. Neurology. 76, 1302-9.

Stankiewicz P.and Lupski J. R. 2010. Structural variation in the human genome and its role in disease. Annu Rev Med. 61, 437-55. 
Lee J. A.and Lupski J. R. 2006. Genomic rearrangements and gene copy-number alterations as a cause of nervous system disorders. Neuron. 52, 103-21.

Michan S., Li Y., Chou M. M., Parrella E., Ge H., Long J. M., Allard J. S., Lewis K., Miller M., Xu W., Mervis R. F., Chen J., Guerin K. I., Smith L. E., McBurney M. W., Sinclair D. A., Baudry M., de Cabo R.and Longo V. D. 2010. SIRT1 is essential for normal cognitive function and synaptic plasticity. The Journal of neuroscience : the official journal of the Society for Neuroscience. 30, 9695-707.

Min S. W., Cho S. H., Zhou Y., Schroeder S., Haroutunian V., Seeley W. W., Huang E. J., Shen Y., Masliah E., Mukherjee C., Meyers D., Cole P. A., Ott M.and Gan L. 2010. Acetylation of tau inhibits its degradation and contributes to tauopathy. Neuron. 67, 953-66.

Shaw C. A., Li Y., Wiszniewska J., Chasse S., Zaidi S. N., Jin W., Dawson B., Wilhelmsen K., Lupski J. R., Belmont J. W., Doody R. S.and Szigeti K. 2011. Olfactory copy number association with age at onset of Alzheimer disease. Neurology. 76, 1302-9.

Stankiewicz P.and Lupski J. R. 2010. Structural variation in the human genome and its role in disease. Annu Rev Med. 61, 437-55. 


\section{FIGURE LEGEND}

Figure 1. 7q22.2 rare CNV detected in a subject with late-onset Alzheimer's disease. (A) Array-CGH profile of the genomic segment containing the 7q22.2 deletion (image based on the Genome Workbench software). (B) Ideogram of chromosome 7 showing the position of the CNV (small vertical red bar). (C) The NAMPT gene, indicated by the blue line in the Reference Sequence (RefSeq) genes track, partially overlaps the 7q22.2 deletion; a CNV reported in the general population (blue bar) maps within the deletion but outside the NAMPT gene (image derived from the UCSC Genome Browser, freeze September 2012). 
To Dr Gracy Rani

Journal of Genetics

Ref.: Ms. No. JGEN-D-13-00241

Dear Dr Rani

Please find a revised version of the manuscript "A microdeletion in Alzheimer's disease disrupts NAMPT gene" that we are resubmitting for publication in the Journal of Genetics. Below please find the response to the reviewers.

\section{Reviewer \#1}

Copy number variations (CNV) can result from inheritance as well as de novo mutations. In this MS only a single subject has been examined, it is thus difficult to comment about the origin/source of this microdeletion.

However, the deletion is observed in an important gene involved in NAD biosynthesis and may contribute to plaque formation. Thus, it is a good indication that NAMPT may be associated with AD. Further validation of the association of this gene is needed in more number of patients. Moreover the authors have not done any biological validation of this novel deletion in the function of NAMPT protein.

In my opinion, this finding can be recommended to be published as a short report/short note in "Journal of Genetics".

The Reviewer pointed out correctly that this is a single observation and further studies are needed to confirm the relevance of this gene for Alzheimer's disease (AD), which we hope will be stimulated by this report. We added to the manuscript not only a comparison to the large sample studied in DGV but also to the $>1300$ individuals already analyzed by array-CGH in our laboratory for reasons others than $A D$. This $C N V$ has never been observed, confirming that it does not represent a common variant of the Brazilian population. Because of the limited amount of data, the paper is being submitted as a research note.

\section{Reviewer \#2}

This manuscript focuses on the association of a novel DNA copy number variation with late onset Alzheimer's disease. Though the observations reported here are interesting, there are some minor issues with the manuscripts. First of all, this report is from a single patient. Was the presence of this CNV validated using some other method? Could the authors comment on the frequency of this CNV? Also it would benefit the audience if a better description of the methodology used to identify CNVs is added to the manuscript. I am also 
curious to know what other CNVs/SNPs was observed in this patient along with the reported CNV in NAMPT gene.

The CNV was indeed observed in a single patient among more than 1300 individuals studied in our laboratory for different reasons. Therefore, the frequency of the CNV is very low not only in the population documented in DGV but also among Brazilian individuals. The CNV was confirmed by reverse labeled hybridization, as showed in the figure enclosed for the Reviewer and also described in the method, which is now more detailed. This approach has been proved to be very consistent during the experimental period of array-CGH in our laboratory, when the finding of the first 300 patients were all confirmed by FISH (Rosenberg $C$ et al. Hum.Genet. 2005; 116:390. Krepischi-Santos AC et al Cytogenet.Genome Res. 2006; 115:254). A table with all CNVs of the patient was included.

Minor issues: Add the full name of the NAMPT gene (2nd page,15th line).

It was added.

The sentence on 4th page,18th line ('However, there are no reports..') is confusing. It would be good if its reformatted.

It was reformatted.

\section{Reviewer \#3}

This is an interesting paper showing a deletion in NAMPT in the brain of an AD patient. Of course, one can not assume cause and effect with an $N=1$, but the deletion is provocative and may stimulate a more comprehensive analysis of a link between NAMPT and late onset AD.

Table 1. Copy number variations identified in the subject with late-onset Alzheimer's disease

\begin{tabular}{lllllcl}
\hline Chr & Cytoband & Start (bp) & End (bp) & CNV type & Size (Kb) & Gene (s) \\
\hline chr1 & p21.1 & 104163795 & 104284223 & del & 120 & AMY2A, AMY1A, AMY1C, AMY1B \\
chr3 & q26.1 & 162540988 & 162618974 & dup & 78 & \\
chr7 & q22.2 & $\mathbf{1 0 5 9 2 3 5 1 5}$ & $\mathbf{1 0 6 0 6 9 1 2 5}$ & del & $\mathbf{1 4 6}$ & NAMPT \\
chr9 & p21.3 & 25259001 & 25347001 & del & 88 & \\
chr15 & q26.1 & 93362475 & 93474032 & del & 112 & CHD2 \\
chrX & q21.1 & 77121672 & 77123784 & del & 2 & MAGT1 \\
Genomic positions based on GRCh37 Build reference sequence. Highlighted in bold is a rare CNV with relevant gene content for \\
the investigated phenotype. CNV= copy number variation; del = deletion; dup = duplication.
\end{tabular}




\section{ANEXO III}

(Manuscrito publicado na revista Genetics and Molecular Biology) 
Short Communication

\title{
Germline DNA copy number variation in individuals with Argyrophilic grain disease reveals CTNS as a plausible candidate gene
}

Darine Villela ${ }^{1}$, Lilian Kimura ${ }^{1}$, David Schlesinger ${ }^{2}$, Amanda Gonçalves ${ }^{3}$, Peter L. Pearson ${ }^{1}$, Claudia K. Suemoto ${ }^{4}$, Carlos Pasqualucci ${ }^{5}$, Ana Cristina Krepischi ${ }^{3}$, Lea T. Grinberg ${ }^{5}$ and Carla Rosenberg ${ }^{1}$

${ }^{l}$ Departamento de Genética e Biologia Evolutiva, Instituto de Biociências, Universidade de São Paulo, São Paulo, SP, Brazil.

${ }^{2}$ Instituto Israelita de Ensino e Pesquisa Albert Einstein, São Paulo, SP, Brazil.

${ }^{3}$ Instituto Nacional de Ciência e Tecnologia em Oncogenômica, Hospital AC Camargo, São Paulo, SP, Brazil.

${ }^{4}$ Departamento de Medicina Interna, Faculdade de Medicina da Universidade de São Paulo, São Paulo, SP, Brazil.

${ }^{5}$ Departamento de Patologia, Banco de Encéfalos Humanos do Grupo de Estudos em Envelhecimento Cerebral, Faculdade de Medicina, Universidade de São Paulo, São Paulo, SP, Brazil.

\begin{abstract}
Argyrophilic grain disease (AGD) is a progressive neurodegenerative disease of the human brain that has never been associated to a particular gene locus. In the present study, we report the results of a CNV investigation in 29 individuals whose anatomopathologic investigation of the brain showed AGD. Rare CNVs were identified in six patients $(21 \%)$, in particular a $40 \mathrm{~kb}$ deletion at 17p13.2 encompassing the CTNS gene. Homozygote mutations in CTNS are known to cause cystinosis, a disorder characterized by the intralysosomal accumulation of cystine in all tissues. We present the first CNV results in individuals presenting AGD and a possible candidate gene implicated in the disorder.
\end{abstract}

Keywords: Argyrophilic grain disease, copy number variations, CNVs, array-CGH, CTNS

Received: May 16, 2013; Accepted: October 8, 2013.

Argyrophilic grain disease (AGD) is a neurodegenerative disorder of the aged human brain morphologically characterized by the presence of argyrophilic grains (AG) mainly in limbic areas. Several studies have shown frequent association of AGD with other tauopathies such as Alzheimer's and Pick's diseases, and its prevalence increases significantly with age, present in up to $40 \%$ of all 85 years or older individuals (Tolnay and Clavaguera, 2004). However, the cause of AGD remains unknown; the disease seems to be sporadic but genetic studies have failed to discover a link between AGD and a particular gene locus.

The contribution of DNA copy number variations (CNVs) in the phenotypes of various complex diseases has been widely demonstrated over the past years. In fact, CNVs are increasingly recognized to be a prevalent form of common genetic variation in the human population. Even though a great number of studies have demonstrated the role of CNVs in the etiology of several neuropsychiatric

Send correspondence to Carla Rosenberg. Department of Genetics and Evolutionary Biology, Institute of Biosciences, University of São Paulo, Rua do Matão 277, 05508-090, São Paulo-SP, Brazil. E-mail: carlarosenberg@uol.com.br. disorders (Lee and Lupski, 2006; Cook and Scherer, 2008) there are no reports of specific $\mathrm{CNV}$ s related do AGD. Here, we identified rare constitutive CNVs in individuals with AGD, in particular one at $17 \mathrm{p} 13.2$ that points to deletions in the cystinosin, lysosomal cystine transporter gene, CTNS, as strong candidate to cause AGD.

The Brain Bank of the Brazilian Aging Brain Study Group (BBBABSG) (Grinberg et al., 2007) provided DNA from blood samples of 29 individuals with AGD. The individuals of our group ranged in age from 50 to 89 and included females and males. Table 1 presents the characterization of all cases investigated in this study. The neuropathological diagnosis of AGD was based, at least, on the presence of AG in hippocampal CA1 area (CA - Cornu Ammonis) and entorhinal region, as well as in pretangles in hippocampal CA2 area in sections immunostained with the phosphor-tau antibody (PHF1, 1:1000, gift from Peter Davies, NY) according to accepted criteria (Braak and Braak, 1987). The subject's clinical and functional statuses were assessed through a knowledgeable informant based on a validated clinical protocol. The protocol includes a series of semi-structured scales and questionnaires that cover ma- 
Table 1 - Case profiles of the all subjects with Argyrophilic grain disease investigated in this study

\begin{tabular}{|c|c|c|c|c|c|c|c|}
\hline \multirow[t]{2}{*}{ Case } & \multirow{2}{*}{$\begin{array}{l}\text { Age at death } \\
\text { (years) }\end{array}$} & \multirow[t]{2}{*}{ Gender } & \multicolumn{3}{|c|}{ Stages of senile changes } & \multirow[t]{2}{*}{ Additional pathology } & \multirow[t]{2}{*}{ Cause of death } \\
\hline & & & NFT & SP & LB & & \\
\hline 1 & 85 & F & 3 & A & - & - & Chronic obstructive pulmonary disease \\
\hline 2 & 89 & $\mathrm{~F}$ & 2 & 0 & - & VD & Pulmonary thromboembolism \\
\hline 3 & 85 & $\mathrm{~F}$ & 3 & B & - & - & Esophageal cancer \\
\hline 4 & 84 & $\mathrm{~F}$ & 0 & 0 & - & - & Acute pulmonary edema \\
\hline 5 & 78 & M & 2 & A & - & VD & Peritonitis \\
\hline 6 & 85 & $\mathrm{~F}$ & 2 & 0 & - & - & Aortic aneurysm \\
\hline 7 & 79 & M & 0 & 0 & - & - & Gastric ulcer \\
\hline 8 & 82 & $\mathrm{~F}$ & 2 & 0 & - & - & Aortic aneurysm \\
\hline 9 & 72 & $\mathrm{~F}$ & 1 & 0 & - & VD & Ischemic heart disease \\
\hline 10 & 75 & $\mathrm{~F}$ & 2 & \multicolumn{2}{|c|}{ B } & PD & Pulmonary thromboembolism \\
\hline 11 & 67 & $\mathrm{~F}$ & 1 & 0 & - & - & Pneumonia \\
\hline 12 & 76 & $\mathrm{~F}$ & 3 & 0 & - & - & Heart failure \\
\hline 13 & 80 & M & 3 & A & - & - & Pneumonia \\
\hline 14 & 73 & $\mathrm{~F}$ & 3 & 0 & - & - & Myocardial sclerosis \\
\hline 15 & 81 & $\mathrm{~F}$ & 4 & $\mathrm{C}$ & - & $\mathrm{AD}+\mathrm{VD}$ & Aortic aneurysm \\
\hline 16 & 59 & M & 1 & 0 & - & - & Pneumonia \\
\hline 17 & 80 & M & 2 & 0 & - & - & Hypertensive heart disease \\
\hline 18 & 86 & M & 4 & 0 & - & - & Heart failure \\
\hline 19 & 58 & M & 1 & 0 & - & - & Coronary artery disease \\
\hline 20 & 50 & M & 1 & 0 & - & - & Pneumonia \\
\hline 21 & 76 & $\mathrm{~F}$ & 0 & 0 & - & - & Perforated gastric ulcer \\
\hline 22 & 76 & M & 0 & 0 & - & - & Myocardial infarction \\
\hline 23 & 80 & M & 0 & 0 & - & - & Myocardial infarction \\
\hline 24 & 88 & $\mathrm{~F}$ & 3 & 0 & - & - & Ischemic heart disease \\
\hline 25 & 69 & $\mathrm{~F}$ & 1 & 0 & - & - & Pulmonary thromboembolism \\
\hline 26 & 83 & $\mathrm{~F}$ & 3 & A & - & - & Myocardial infarction \\
\hline 27 & 85 & $\mathrm{~F}$ & 3 & 0 & - & - & Pneumonia \\
\hline 28 & 89 & M & 2 & 0 & - & - & Duodenal ulcer bleeding \\
\hline 29 & 80 & M & 3 & A & - & - & Chronic obstructive pulmonary disease \\
\hline
\end{tabular}

NFT=neurofibrillary tangle, Braak stage; $\mathrm{SP}=$ senile plaque, $\mathrm{CERAD}$ (Consortium to Establish a Registry for Alzheimer's Disease); LB=Lewy body; $\mathrm{VD}=$ vascular dementia; $\mathrm{PD}=$ Parkinson disease; $\mathrm{AD}=$ Alzheimer's disease.

jor functional abilities and were validated for assessment with an informant (Grinberg et al., 2007). BBBABSG's procedures were approved by the Ethical Board of University of São Paulo Medical School and the next-of-kin agreed to participate and signed an informed written consent.

To identify CNVs we performed oligonucleotide comparative genomic hybridization based on microarrays (array-CGH) using a whole-genome platform containing $\sim 180.000$ oligonucleotides (180k platform) (Oxford Gene Technologies, UK). Briefly, samples were labeled with Cy3- and Cy5-deoxycytidine triphosphates by random priming. Purification, hybridization and washing were carried out as previously reported (Krepischi et al., 2010). Scanned images of the arrays were processed using Feature Extraction software and data were analyzed with the
Genomic Workbench software, both from Agilent Technologies. To distinguish CNVs, we used the Aberration Detection Method 2 statistical algorithm (ADM2) with a sensitivity threshold of 6.7. A genomic segment was considered duplicated or deleted when the $\log _{2}$ ratio of the Test/Reference fluorescent intensities of a given region encompassing at least three probes was above 0.3 or below -0.3 , respectively. Detected CNVs were compared to CNV data from oligoarray studies documented in the Database of Genomic Variants (DGV). The relevant CNVs were validated by dye-swap hybridizations, and only a mirror result would be confirmatory of the CNVs presence.

The array-CGH analysis revealed rare $\mathrm{CNVs}$ (rare defined as frequency $<0.1 \%$ of population, based on DGV) in six individuals among the 29 with AGD, none of them re- 
current. To exclude that these rare CNVs represent common variants in the Brazilian population, we compiled $\mathrm{CNV}$ data obtained with the same $180 \mathrm{~K}$ array-CGH platform from more than 400 independent samples studied in our laboratory for reasons other than dementia. None of the rare $\mathrm{CNVs}$ documented in this study were detected in these subjects. Table 2 summarizes the rare CNVs identified in our group and shows the genes encompassed by these genomic imbalances. Any of the rare CNVs detected are potential candidates for the investigated phenotype; however, we highlighted the genomic $40 \mathrm{~kb}$ microdeletion of at $17 \mathrm{p} 13.2$ that includes the CTNS gene as especially interesting due to its relevant gene content and the lack of reports on copy number changes affecting this gene. Figure 1 shows the validation of this $\mathrm{CNV}$ made by reverse labeling hybridization, where it is possible to see that the alteration is mirrored.

Table 2 - Descriptions of all rare copy number variations identified in the individuals with Argyrophilic grain disease.

\begin{tabular}{lccccccl}
\hline Case & Chr & Cytoband & Start site & End site & CNV type & Size $(\mathrm{kb})$ & Gene $(\mathrm{s})$ \\
\hline 2 & 10 & $\mathrm{p} 13$ & 14996608 & 15043743 & del & 44 & MEIG1 \\
3 & 9 & $\mathrm{p} 24.1$ & 5763235 & 5881920 & del & 70 & KIAA1432, ERMP1 \\
$\mathbf{4}$ & $\mathbf{1 7}$ & $\mathbf{p 1 3 . 2}$ & $\mathbf{3 5 2 7 6 2 8}$ & $\mathbf{3 5 6 0 1 1 8}$ & del & $\mathbf{4 0}$ & SHPK, CTNS \\
14 & 1 & $\mathrm{p} 31.1$ & 78594557 & 79456374 & dup & 789 & GIPC2, MGC27382, PTGFR, IFI44L, ELTD1 \\
17 & 12 & $\mathrm{q} 12.1$ & 25723651 & 25755485 & del & 30 & IFLTD1 \\
21 & 5 & $\mathrm{q} 14.2-\mathrm{q} 14.3$ & 82630761 & 82851414 & dup & 103 & XRCC4, VCAN \\
\hline
\end{tabular}

Genomic positions based on GRCh37 Build reference sequence. Highlighted in bold is a CNV with relevant gene content for the investigated phenotype. $\mathrm{CNV}=$ copy number variation; del $=$ deletion; dup $=$ duplication.

(A)

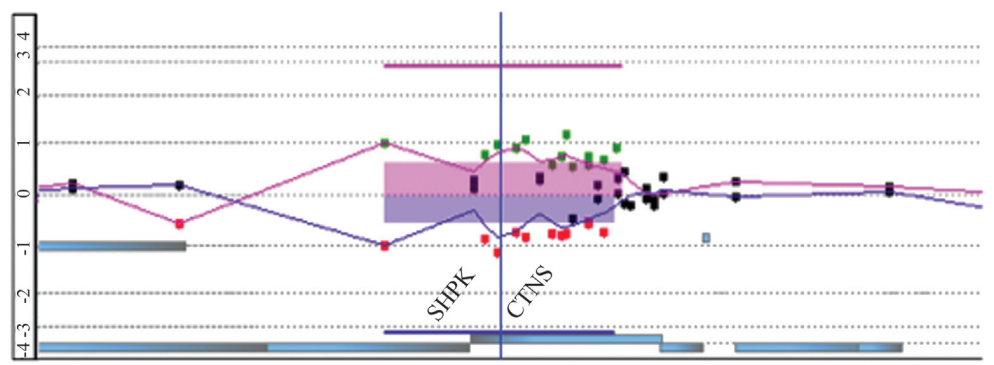

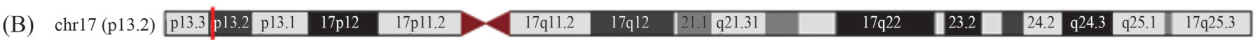

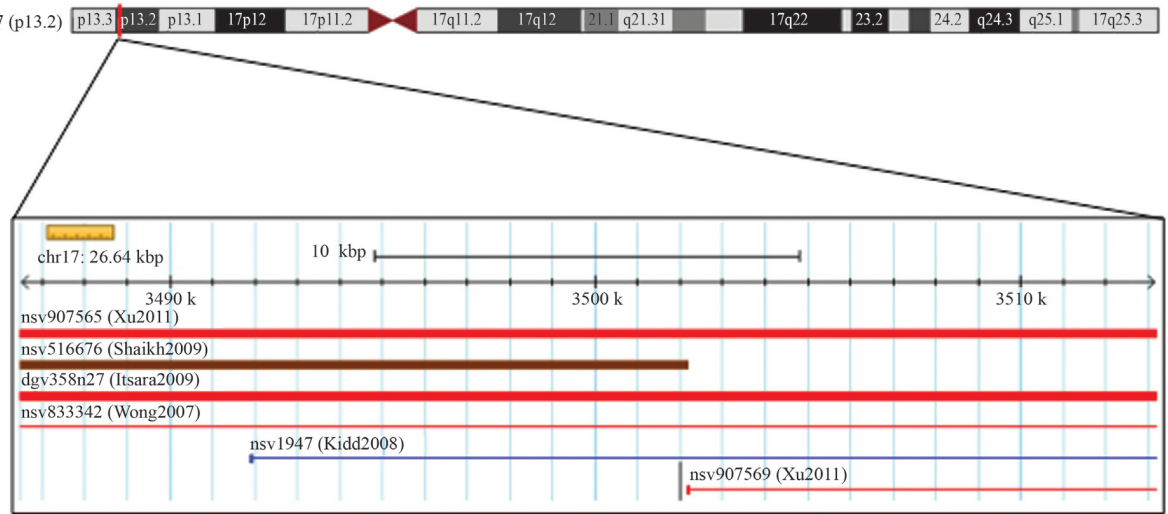

Figure 1 - The 17p13.2 rare CNV detected in a subject with Argyrophilic grain disease. (A) Array-CGH profile of the genomic segment containing the $\mathrm{CNV}$, and its reverse labeling hybridization (image based on the Genome Workbench software); (B) Ideogram of chromosome 17 showing the position of the CNV (small vertical red bar); (C) Region covered by the CNV. CNV loci reported in the general population are indicated by blue (gain), red (loss) and brown (complex rearrangement) bars in the Database of Genomic Variants (DGV) (image derived from the DGV, freeze September 2013). 
The CTNS gene encodes a seven-transmembrane domain protein that functions to transport cystine out of lysosomes. Its activity is driven by the $\mathrm{H}^{+}$electrochemical gradient across the lysosomal membrane. Mutations in this gene cause cystinosis, a rare autosomal recessive disorder characterized by the intralysosomal accumulation of cystine in all tissues (Kalatzis and Antignac, 2002). The most common mutation associated with this rare disease is a deletion of $65 \mathrm{~kb}$ presented in homozygosity that also includes the SHPK gene. The protein encoded by this latter gene has weak homology to several carbohydrate kinases, a class of proteins involved in the phosphorylation of sugars as they enter the cell, inhibiting return across the cell membrane (Wamelink et al., 2008). Our results show a heterozygous deletion in the CTNS gene encompassing the region of this common mutation associated with cystinosis. Literature data demonstrate that the brain is one of the last organs to be affected by the progressive cystine accumulation (Cochat et al., 1986). Cognitive impairments have been documented in some cystinosis patients, which presented deficit in visual-spatial memory (Trauner et al., 1988; Scarvie et al., 1996). Additionally, an investigation showed that Ctns -/- knockout mice present a severe age-related memory deficit (Maurice et al., 2009). Therefore, this evidence makes CTNS a good candidate gene for susceptibility to AGD.

In conclusion, this is the first study to identify a rare $\mathrm{CNV}$ at $17 \mathrm{p} 13.2$ with AGD and links this disease with a particular gene locus, the CTNS.

\section{Acknowledgments}

This work was supported by a FAPESP grant CR (2009/00898-1), and DV was supported by a FAPESP PhD fellowship (2010/15503-0). We thank the Brazilian Aging Brain Study Group for providing DNA samples.

\section{References}

Braak H and Braak E (1987) Argyrophilic grains: Characteristic pathology of cerebral cortex in cases of adult onset dementia without Alzheimer changes. Neurosci Lett 76:124-127.
Cochat P, Drachman R, Gagnadoux MF, Pariente D and Broyer M (1986) Cerebral atrophy and nephropathic cystinosis. Arch Dis Childhood 61:401-403.

Cook Jr EH and Scherer SW (2008) Copy-number variations associated with neuropsychiatric conditions. Nature 455:919923.

Grinberg LT, Ferretti RE, Farfel JM, Leite R, Pasqualucci CA, Rosemberg S, Nitrini R, Saldiva PH and Filho WJ (2007) Brain bank of the Brazilian aging brain study group - A milestone reached and more than 1,600 collected brains. Cell Tissue Banking 8:151-162.

Kalatzis V and Antignac C (2002) Cystinosis: From gene to disease. Nephrol Dial Transplant 17:1883-1886.

Krepischi AC, Knijnenburg J, Bertola DR, Kim CA, Pearson PL, Bijlsma E, Szuhai K, Kok F, Vianna-Morgante AM and Rosenberg C (2010) Two distinct regions in 2q24.2-q24.3 associated with idiopathic epilepsy. Epilepsia 51:24572460.

Lee JA and Lupski JR (2006) Genomic rearrangements and gene copy-number alterations as a cause of nervous system disorders. Neuron 52:103-121.

Maurice T, Hippert C, Serratrice N, Dubois G, Jacquet C, Antignac C, Kremer EJ and Kalatzis V (2009) Cystine accumulation in the CNS results in severe age-related memory deficits. Neurobiol Aging 30:987-1000.

Scarvie KM, Ballantyne AO and Trauner DA (1996) Visuomotor performance in children with infantile nephropathic cystinosis. Percept Mot Skills 82:67-75.

Tolnay M and Clavaguera F (2004) Argyrophilic grain disease: A late-onset dementia with distinctive features among tauopathies. Neuropathology 24:269-83.

Trauner DA, Chase C, Scheller J, Katz B and Schneider JA (1988) Neurologic and cognitive deficits in children with cystinosis. J Pediatr 112:912-914

Wamelink MM, Struys EA, Jansen EE, Levtchenko EN, Zijlstra FS, Engelke U, Blom HJ, Jakobs C and Wevers RA (2008) Sedoheptulokinase deficiency due to a $57-\mathrm{kb}$ deletion in cystinosis patients causes urinary accumulation of sedoheptulose: Elucidation of the CARKL gene. Hum Mutat 29:532-536.

Associate Editor: Carlos F.M. Menck

License information: This is an open-access article distributed under the terms of the Creative Commons Attribution License, which permits unrestricted use, distribution, and
reproduction in any medium, provided the original work is properly cited. 